Carla Silva Machado

\title{
“ESPELHO, ESPELHO MEU?”: NARRATIVAS AUDIOVISUAIS ACERCA DAS JUVENTUDES E RELAÇÕES JUVENIS
}

\section{TESE DE DOUTORADO}

DEPARTAMENTO DE EDUCAÇÃO Programa de Pós-Graduação em Educação 
Pontifícia Universidade Católica $_{\text {a }}$

GRAVE

\author{
Carla Silva Machado
}

“ESPELHO, ESPELHO MEU?”: NARRATIVAS

AUDIOVISUAIS ACERCA DAS JUVENTUDES E RELAÇÕES

JUVENIS

Tese de Doutorado

Tese apresentada ao Programa de Pós-graduação em Educação da PUC-Rio como requisito parcial para obtenção do grau de Doutor em Educação.

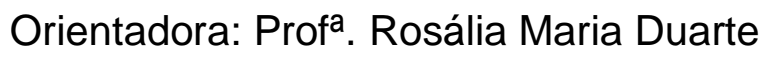




\title{
Pontifícia Universidade Católica $_{\text {a }}$
}

Carla Silva Machado

“ESPELHO, ESPELHO MEU?”: NARRATIVAS

\section{AUDIOVISUAIS ACERCA DAS JUVENTUDES E RELAÇÕES}

JUVENIS

Tese apresentada como requisito parcial para obtenção do grau de Doutor pelo Programa de Pósgraduação em Educação do Departamento de Educação do Centro de Teologia e Ciências Humanas da PUC-Rio. Aprovada pela Comissão Examinadora abaixo assinada.

\author{
Profá. Rosália Maria Duarte \\ Orientadora \\ Departamento de Educação - PUC-Rio \\ Profa. Magda Pischetola \\ Departamento de Educação - PUC-Rio \\ Profa. Silvana Soares de Araújo Mesquita \\ Departamento de Educação - PUC-Rio \\ Prof ${ }^{a}$. Milene de Cássia Silveira Gusmão
} Departamento de Filosofia e Ciências Humanas - UESB

Prof. André Bocchetti Faculdade de Educação - UFRJ

Prof ${ }^{a}$. Monah Winograd Coordenadora Setorial do Centro de Teologia e Ciências Humanas

PUC-Rio

Rio de Janeiro, 11 de dezembro de 2017 
Todos os direitos reservados. É proibida a reprodução total ou parcial do trabalho sem autorização do autor, do orientador e da universidade.

\section{Carla Silva Machado}

Licenciada em Letras pela Universidade Federal de Viçosa em 1999 e Mestra em Educação pela Universidade Federal de Juiz de Fora (UFJF) em 2005. No doutorado, foi Bolsista - Aluna Nota 10 da Fundação de Amparo à Pesquisa do Estado do Rio de Janeiro (Faperj) a partir de agosto de 2016 e do Conselho Nacional de Desenvolvimento Científico e Tecnológico (CNPq) entre março/2015 e julho/2016. É integrante do Grupo de Pesquisa Educação e Mídias (Grupem), coordenado pela Profa . $\mathrm{Dr}^{\mathrm{a}}$. Rosália Duarte. Foi Analista de Formação em EaD no Centro de Políticas Públicas e Avaliação da Educação (CAEd) da UFJF, trabalhando como suporte de orientação institucional do mestrado profissional em Gestão e Avaliação da Educação Pública de outubro de 2011 a maio de 2015.

Ficha Catalográfica

Machado, Carla Silva

"Espelho, espelho meu?" : narrativas audiovisuais acerca das juventudes e relações juvenis / Carla Silva Machado ; orientadora: Rosália Maria Duarte. - 2017.

172 f. ; $30 \mathrm{~cm}$

Tese (doutorado) - Pontifícia Universidade Católica do Rio de Janeiro, Departamento de Educação, 2017.

Inclui bibliografia

1. Educação - Teses. 2. Juventudes. 3. Audiovisual. 4. Indústria cultural. 5. Culturas juvenis. I. Duarte, Rosália Maria. II. Pontifícia Universidade Católica do Rio de Janeiro. Departamento de Educação. III. Título. 
Dedico este trabalho ao meu avô, José Ibraim (in memoriam), o primeiro a apostar na potência da minha escrita, e aos meus pais: Lia e Raimundo, meus mais constantes incentivadores. 


\section{Agradecimentos}

Agradecer é também narrar e narrar-se! Sou muito grata à vida pelas pessoas que conheci, os amigos que fiz e as oportunidades alcançadas ao longo de minha trajetória.

Agradeço ao meu avô, senhor José Ibraim, por me ensinar que viver é um ato político e militar é necessário.

Agradeço imensamente aos meus pais, por serem meus educadores mais presentes, mais entusiastas, mais queridos e afetuosos. Rodrigo, Amanda e eu somos seres abençoados cotidianamente pela presença de vocês em nossas vidas.

Agradeço à Amanda Machado, minha irmã tão querida e talentosa, minha mais fiel companheira nas salas de cinema, com quem o tempo voa ao falarmos dos livros, filmes, músicas e poesia.

Ao Rodrigo Machado, meu irmão que tem o coração maior que o mundo, com quem compartilhei as aventuras da infância e o vi tantas vezes sendo o Homem-Aranha em nossas brincadeiras, certamente, estes escritos têm um pouco de você. À Luiza, Julia e Renata, as meninas de sua vida e que enchem nossas vidas de alegrias.

Ao Fernando, que viveu intensamente comigo as alegrias e tristezas do processo de doutoramento. Ao me dizer sim, ele disse sim aos meus livros e a tudo o que eles representam. Seu apoio foi essencial nessa conquista!

Ao meu primo-irmão Alonso, que vive distante, mas é tão próximo e sabe o quanto esse momento é importante para mim.

Aos meus amigos queridos: Vanessa Nolasco, que me acolheu no Rio de Janeiro e me fez sentir em casa, ocupando seu sofá-cama semanalmente; Juliana Magaldi, que me deu Janaína de presente e me deixa brincar de ser tia dela; Carol Magaldi, minha parceira acadêmica, pela qual tenho enorme admiração. À Dulce Maria e Maria Inês, doces e afetuosas meninas que carrego desde a infância. À Elizabeth Caldas, que transformou os sujeitos desta pesquisa em pequenos produtores de cinema. À Mirna Juliana, companheira que a PUC me apresentou e que eu espero levar para muitas aventuras ao longo da vida. À Keite, outra boa parceira que a PUC me deu e que embarca em minhas viagens como boa libriana. À Christiane Milagres, pelas horas de escuta atenta e carinhosa.

Aos queridíssimos: Leonardo Vilardi, Luisa Vilardi, Rubens Ragone, Cristiane Moreira, Anderson Pires, Lílian Cavalcanti, Angélica Martins e Giovana Castro, compartilho com vocês os desejos de Drummond: "Mas se desejarmos fortemente o melhor e, principalmente, lutarmos pelo melhor, o melhor vai se instalar em nossa vida. Porque sou do tamanho daquilo que vejo, e não do tamanho da minha altura". 
Aos professores que marcaram minha vida, alguns por terem sido meus educadores, outros por eu poder me espelhar: Carlos Alberto Marques (que agora já é até nome de escola), Maria do Socorro Pontes Braga, Lucimar Rodrigues Santiago, Luciana Pacheco, Marcelo Andrade (exemplo de professor e de ser humano), Vera Candau, Alícia Bonamino, Anderson Ferrari, Márcia Machado, Marcos Tanure e Marcus David.

Aos colegas da turma de doutorado, pelas constantes trocas e compartilhamentos: ter vocês por perto, mesmo que virtualmente, deixou o caminho mais florido, leve e alegre.

Ao Valério que desde os tempos de UFV sempre quebra meus galhos e me ajudou no desenvolvimento do projeto piloto.

Aos muitos amigos que fiz durante minha vida acadêmica, especialmente a: Rodrigo Frausino, Julian Rodrigues, Kátia Cilene, Wesley Francisco, Juliana Sari, Sandra Medeiros, Fernanda Abrão, Maria Côrtes, Tatiana Góes, Glau Barcelos, Everthon Marques, Helton Nonato, Adailton, Fernandinha Dias de Oliveira.

Aos alunos que tive e que sempre serão meus alunos, muito obrigada por me ensinarem tanto ao longo desta caminhada!

À Priscila Sant'anna que foi super generosa ao me receber para fazer a pesquisa de campo em suas turmas, abrindo sua escola e, aos poucos, abrindo-se também para inúmeras parcerias. Muito obrigada pela confiança.

À Secretaria Municipal de Educação de Juiz de Fora, em especial à Denise Vieira Franco e Andrea Borges, que autorizaram o desenvolvimento desta pesquisa numa das escolas da rede. À Rachel Lau e Gustamara, diretora e vice-diretora da escola em que a pesquisa foi realizada, agradeço pela acolhida e por serem extremamente disponíveis aos meus pedidos em algumas quebras de rotina da escola.

Aos meninos e meninas da escola pesquisada, que foram enormes parceiros na construção deste trabalho e que me enchem de orgulho por terem um olhar tão carinhoso com a escola, por me receberem tão bem e me fazerem sentir parte do seu cotidiano.

Aos queridos colegas do Grupem (Grupo de Pesquisa em Educação e Mídias), que sempre tiveram um ouvido atento para os meus casos de pesquisa. Ao GESED/UFJF, por me acolher quando eu ainda estava na fase de escrita do projeto de doutorado.

À Rosália Duarte, minha orientadora, pela qual eu já tinha uma enorme admiração, mesmo só conhecendo seus escritos, e que durante o processo de orientação, soube me conduzir pelos caminhos da escrita: agradeço a paciência, a dedicação e também os puxões de orelha; ter você por perto fez toda a diferença em minha vida, você me apresentou uma maneira de fazer pesquisa que levarei para sempre. 
Aos professores que brilhantemente contribuíram para o resultado final deste trabalho, estando presentes nas bancas de qualificação I e II, especialmente à professora Magda Pischetola, que esteve em todas as bancas pelas quais passei neste doutorado, inclusive na entrevista.

Aos professores Magda Pischetola, Silvana Mesquita, Milene Santiago e André Bocchetti, que aceitaram o convite para estar na banca de defesa e que puderam ser meus leitores atentos: muito obrigada!

Ao CAEd/UFJF pela liberação semanal, quando eu ainda era funcionária da instituição, para assistir às aulas no Rio, pelos aprendizados constantes e pelos amigos que cultivei.

À PUC-Rio pela bolsa de isenção sem a qual não teria sido possível cursar a pós-graduação, ao Departamento de Educação pela acolhida, em especial à Nancy e Marnie, sempre muito atentas e carinhosas, atendendo minhas urgências.

Às agências financiadoras de pesquisa no Brasil, em especial ao CNPq e à Faperj, que financiaram parte desta pesquisa, que se mantenham fortes, pois "eles passarão!". 


\section{Resumo}

Machado, Carla Silva; Duarte, Rosália Maria. "Espelho, espelho meu?": narrativas audiovisuais acerca das juventudes e relações juvenis. Rio de Janeiro, 2017. 172p. Tese de Doutorado Departamento de Educação, Pontifícia Universidade Católica do Rio de Janeiro.

Esta tese discute as relações entre juventudes e audiovisual. Foram analisadas as relações de jovens da periferia de Juiz de Fora com os filmes que assistem, usando os diversos suportes. Nesse sentido, foram selecionados filmes de grandes bilheterias que possuíam jovens como protagonistas. Os filmes selecionados foram visualizados por jovens estudantes de uma escola municipal de bairro periférico da cidade de Juiz de Fora-MG, em oficinas nas quais eram propostas atividades empíricas que objetivavam entender a relação deles com os filmes vistos. O material produzido na pesquisa de campo - áudios, textos, desenhos, vídeos - foi analisado com auxílio do software Atlas $\mathrm{TI}$ e à luz do referencial teóricometodológico que trata da análise de conteúdo, considerando as relações entre comunicação, poder, indústria cultural, juventudes e escola. Os estudos do grupo de Comunicação Latino-americanos embasam os conceitos desta tese, assim como os estudos de juventudes, desenvolvidos por grupos de pesquisa e observatórios da juventude da Universidade Federal de Minas Gerais e Universidade Federal Fluminense. Os resultados apontam para a forte influência dos filmes estadunidenses no cotidiano do grupo pesquisado, além disso, a relação desses jovens com os super-heróis ficou bastante evidenciada, e ainda, a necessidade de que a escola participe da formação estética audiovisual deles.

\section{Palavras-chave}

Juventudes; Audiovisual; Indústria Cultural; Culturas Juvenis. 


\section{Abstract}

Machado, Carla Silva; Duarte, Rosália Maria (Advisor). Mirror, mirror on the wall?: audiovisual narratives regarding youth and its relations. Rio de Janeiro, 2017. 172p. Tese de Doutorado Departamento de Educação, Pontifícia Universidade Católica do Rio de Janeiro.

The present thesis discusses the relationship between youth and the audiovisual. The focus of the analysis was the relationship between the youngsters from the outskirts of Juiz de Fora with the films they watch, utilizing various types of media. Therefore, blockbuster films with young protagonists were selected. The selected films were watched by young students of a municipal school in the outskirts of the city of Juiz de Fora MG, in workshops in which empirical activities were proposed which were aimed at understanding their connection to the films they watched. The material produced during the fieldwork - audio files, texts, drawings, video files - were analyzed with the help of the Atlas TI software and based on the theoretical framework of Content Analysis, considering the connections between communication, power, cultural industry, youth and school. The studies by the Latin American Communication group provided the basis to the concepts in this thesis, as well as the youth observatory of the Federal University of Minas Gerais and the Fluminense Federal University. The results point to a strong influence of US films in the everyday life of the researched group, also the students' connection to super heroes was highlighted, besides the need for the school to participate in their aesthetic audiovisual experience.

\section{Keywords}

Youth; Audiovisual; Cultural Industry; Youth culture. 


\section{Sumário}

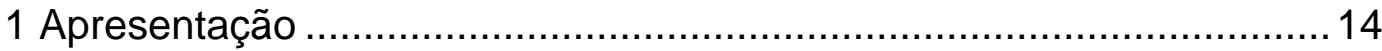

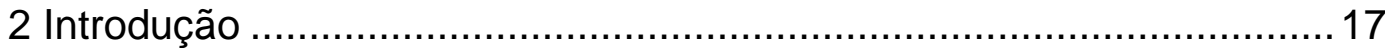

2.1 Objeto e problema de pesquisa..................................................... 19

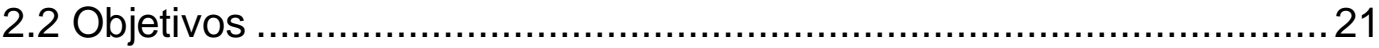

3 Comunicação, indústria cultural e juventudes ....................................22

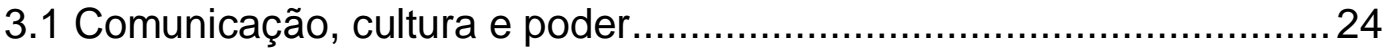

3.2 Hollywood e a indústria cultural ................................................... 30

3.3 Juventudes e jovens espectadores do audiovisual ........................... 34

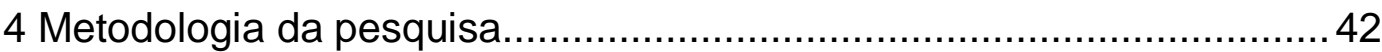

4.1 Como e por que desenvolver pesquisa qualitativa? ......................... 42

4.2 Preparação do trabalho de campo .................................................... 48

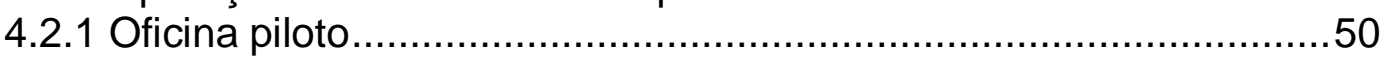

4.2.2 Alguns ajustes após o projeto piloto ...........................................54

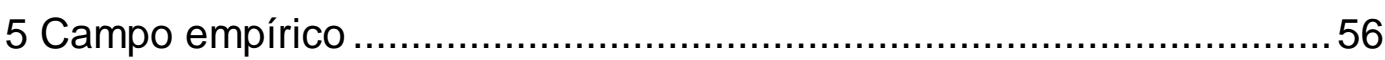

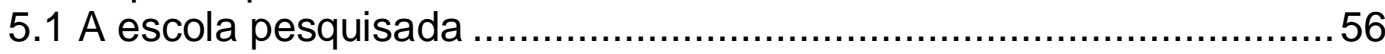

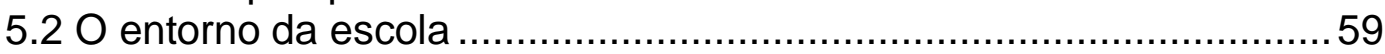

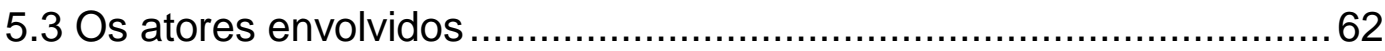

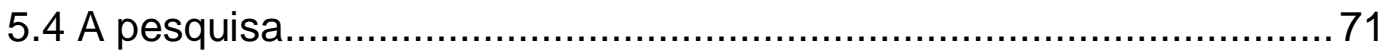

5.5 Eixos analíticos e categorias de análise ........................................... 74

6 A política da estética ou a estética da política? ....................................75

6.1 Padrão estético e narrativo ou a "reprodução do sempre igual" ..........76

6.2 Formação do gosto......................................................................94

6.3 Padronização de representação das juventudes.............................100

6.3.1 Os super-heróis e a cultura de massa .......................................115

7 A necessidade da fantasia: a mágica como solução de conflitos........123

7.1 Dois filmes, duas concepções, dois olhares ................................... 124

7.2 O cinema como um espelho desfocado ou Vamos produzir

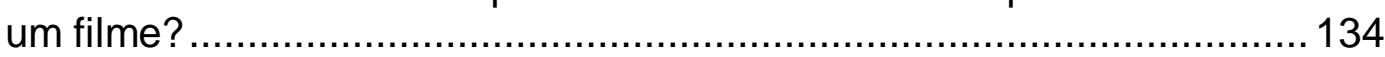

7.2.1 Vamos falar sobre o quê? ………………........................... 135

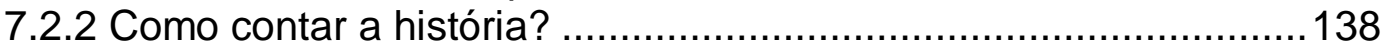

7.2.3 Quando o espelho causa estranhamento: retratar-se ou

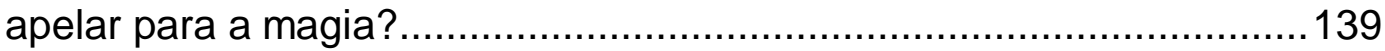

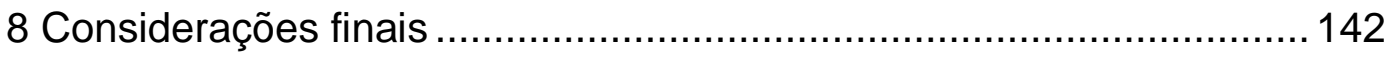

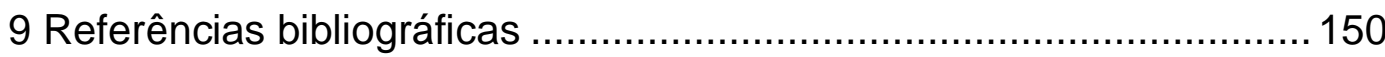

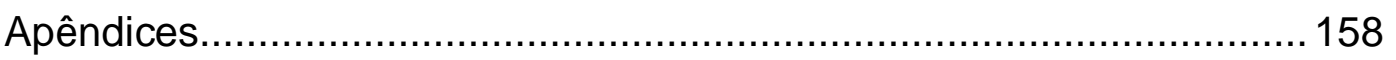




\section{Lista de Gráficos}

Gráfico 1 - Idade dos participantes da pesquisa................................64

Gráfico 2 - Idade em que os jovens começaram a ver filmes ................64

Gráfico 3 - Onde os jovens informaram ver filmes na infância ...............65

Gráfico 4 - Frequência com que os jovens iam ao cinema na infância....66

Gráfico 5 - Frequência com que os jovens vão ao cinema ....................66

Gráfico 6 - Dispositivos em que os jovens assistem a filmes com mais

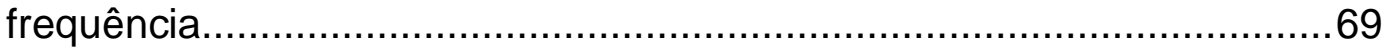

Gráfico 7 - Média do número de filmes que os jovens assistem por semana 69

Gráfico 8 - O último filme a que os jovens assistiram ..........................70

Gráfico 9 - Filmes a que os jovens gostariam de assistir....................71 


\section{Lista de Quadros}

Quadro 1 - Canais de TV por assinatura divididos por gênero ................68

Quadro 2 - Resumo dos encontros realizados na pesquisa .....................73

Quadro 3 - Dados de mercado dos filmes vistos pelos jovens nas

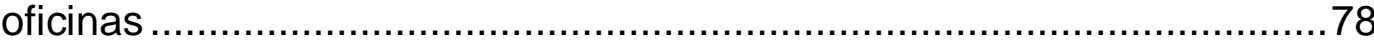

Quadro 4 - Ficha técnica dos filmes vistos pelos jovens nas oficinas .....82

Quadro 5 - Construção narrativa dos filmes vistos pelos jovens nas oficinas

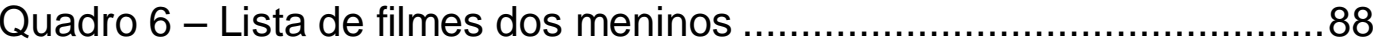

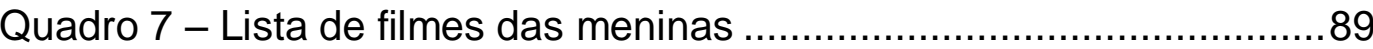

Quadro 8 - Nomes escolhidos pelos participantes das oficinas e breve história das personagens

Quadro 9 - Personalidades escolhidas para serem ídolos dos protagonistas de A culpa é das estrelas

Quadro 10 - As principais personagens de Confusões de adolescentes 126

Quadro 11 - Respostas dos grupos sobre a proposta de roteiro 136 
"Os jovens são o que são, mas também são (sem que o sejam) o que deles se pensa, os mitos que sobre eles se criam. Esses mitos não reflectem a realidade, embora a ajudem a criar."

(José Machado Pais)

"Quando você acha que a gente acha, a gente não acha o que você acha."

(Troll ${ }^{1}$, jovem participante da pesquisa)

\footnotetext{
${ }^{1}$ O nome do participante da pesquisa de campo é fictício, foi o nome escolhido pelo jovem inspirado em um personagem de filme de animação.
} 


\section{Apresentação}

[...] o saber é disperso e fragmentado e pode circular fora dos lugares sagrados nos quais antes estava circunscrito e longe das figuras sociais que antes o administravam. (MartínBarbero, 2000, p. 55).

Este trabalho tem como objetivo central tratar das representações de juventudes no cinema, a partir das perspectivas de um grupo de jovens, estudantes de uma escola pública municipal da cidade de Juiz de Fora, Minas Gerais. A pesquisa de campo investigou se os jovens sentem-se representados pelos filmes que veem ou, ainda, se é possível aprender a ser jovem a partir do cinema.

A presente tese se inscreve no campo de estudos que articula cinema e educação. $O$ interesse pelo tema talvez esteja presente em minha trajetória de vida, posto que sempre fui apaixonada por cinema, pelas salas - muitas vezes cheirando a mofo, por serem antigas e pouco conservadas -, as cadeiras grandes, o cheiro da pipoca, a fila, o ritual para a compra do ingresso e a expectativa pelo filme. Essa paixão não veio da primeira infância, mas floresceu desde a minha primeira ida ao cinema, ao deparar-me com a tela grande.

Essa experiência aconteceu quando eu tinha uns 7 ou 8 anos, quando em um passeio da escola fui ao antigo Cinema Paraíso e assisti a um desenho animado que pude ver tantas outras vezes na TV, e até hoje quando vejo este episódio é como se eu voltasse a pisar naquela sala de cinema onde só entrei aquela vez, pois logo veio a fechar. O desenho era um episódio da Disney com o personagem Pateta, descrito como um homem calmo, mas que se transformava ao entrar num carro e ter de enfrentar o trânsito; esse episódio é chamado Senhor Volante e pode ser visto no canal do YouTube ${ }^{2}$.

Provavelmente essa ida ao cinema tinha a ver com algum projeto de educação no trânsito desenvolvido pela escola, mas só me lembro mesmo da sensação que aquele telão me proporcionou. Desde então, relaciono meu gosto pelo cinema àquela primeira prática proporcionada pela escola. Dessa forma, acredito que o ambiente escolar pode formar espectadores de audiovisual, visto que é possível incluir ali questões ligadas à linguagem do cinema, às temáticas

\footnotetext{
${ }^{2} \mathrm{O}$ episódio está no endereço do YouTube: <https://www.youtube.com/watch?v=RMZ3bsrtJZ0>. Acesso em: 20 abr. 2017.
} 
abordadas, ao contexto de produção e a outros elementos importantes relacionados à produção cinematográfica que contribuem para a formação dos estudantes.

Essa recordação me remete a Alain Bergala (2008), ao comentar o motivo de ter aceitado coordenar o projeto de cinema na escola do Plano de Cinco Anos para as Artes e a Cultura, do Ministério da Cultura francês. A parte do projeto coordenado por ele tinha por objetivo levar o cinema produzido na França para as escolas mais periféricas, onde os filmes não chegavam. $O$ cineasta afirma que:

\begin{abstract}
Mas no fundo, no que me diz respeito, tenho o sentimento de ter encontrado a energia para realizar esse "plano cinema" pensando, antes de tudo, nas crianças que devem se encontrar hoje, mais ou menos na mesma situação em que eu estava na infância: deserdados, distantes da cultura, à espera de uma improvável salvação, com poucas chances sociais de se dar bem sem a escola e não dispondo de um objeto preferido ao qual apegar. Fui imediatamente tocado, desde o primeiro filme de Kiarostami, pela maneira como seus pequenos heróis se fixam em um objeto, uma obsessão, para se salvar, num mundo em que a única chance de existir é resistir a partir de uma paixão pessoal. (Bergala, 2008, p. 13).
\end{abstract}

Bergala defende o cinema como uma maneira de salvar-se e apaixonar-se e faz dessa paixão uma militância pelo cinema como arte e possibilidade pedagógica.

Em minha experiência docente, sempre trabalhei com visualização de filmes em sala de aula. Seja para comparar a linguagem do cinema à linguagem literária, para ilustrar algo da disciplina lecionada ou para criar um público de audiovisual, acredito que essa ação docente esteja relacionada à minha primeira experiência numa sala de cinema e de querer levar a paixão por filmes a outras pessoas.

O título deste trabalho é inspirado em José Machado Pais ${ }^{3}$ que em artigo publicado com Gisele Ramos Rosa, afirma:

De acordo com a metáfora do espelho, a realidade do mundo refletir-se-ia numa superfície, não propriamente feita de vidro, mas de palavras ou de imagens. [...] Pela mão da metáfora do espelho, as representações sociais podem considerar-se fiáveis ou factuais ou, pelo contrário, fonte de confusões e mentiras quando se descobre que o espelho turva ou deforma a realidade refelectida. (Rosa \& Pais, 2009, p. 99-100).

Pais $(2014$, p. 72$)$ desenvolve a relação da realidade com a representação social a partir da metáfora do espelho, ao observar que:

\footnotetext{
${ }^{3}$ Afirmo que o trecho citado é apenas de José Machado Pais, pois em nota de rodapé no artigo os autores anunciam que as "Notas Finais" foram integralmente escritas por ele, e é desta parte do texto que foi retirado o trecho em questão.
} 
Na metáfora do espelho, não há muito o que fazer com o seu reflexo: podemos bafejar e limpar o espelho, indagar se é côncavo ou convexo, mas a imagem refletida acabará por resultar da capacidade do espelho refletir passivamente essa imagem.

Dessa forma, o título deste trabalho é, de maneira metafórica, a pergunta que pretendo responder ao final desta jornada: o cinema pode ser um espelho para a juventude? Em que sentido? Ele espelha a juventude ou a juventude o espelha? 


\title{
2 \\ Introdução
}

\begin{abstract}
O espantoso é que, à medida que o nosso século avança, tentamos ainda, de alguma forma, acompanhar essa bizarra evolução linguística. $O$ que está em ação aqui é uma relação circular e oculta entre aqueles que fazem filmes e aqueles que assistem a filmes, uma região que nunca é vista por ninguém, mas que é uma província de muitos olhos. (Carrière, 2014, p. 20).
\end{abstract}

Este trabalho tem como foco a percepção de jovens acerca das juventudes no audiovisual. Outros trabalhos já foram desenvolvidos na perspectiva de analisar representações de determinados grupos no cinema. O tema da juventude já foi discutido por Henry Giroux (1996), ao tratar da representação "demonizada", desta feita por Hollywood, na década de 1990, a partir da análise do filme Kids (Larry Clark, EUA, 1995), cujos jovens são retratados como acríticos e completamente indisciplinados e desprovidos de qualquer senso ético e moral. Vale comentar que, no caso do estudo de Giroux, foi feita uma análise fílmica, assim como ocorre no estudo desenvolvido por Guacira Lopes Louro (2008), que analisa como filmes hollywoodianos que foram sucesso de público, abordam os temas juventude, gênero e sexualidade. A autora faz um histórico dos filmes para o grande público com personagens homossexuais, apresentando De repente, no último verão (Joseph Mankiewicz, 1959) como sendo o primeiro filme a trazer à tona essa temática. Diferente do que Giroux e Louro fizeram, nesta tese foi possível ouvir os jovens e analisar se eles se sentem representados pelas personagens jovens dos filmes que veem, se eles se identificam com as representações de juventudes com as quais têm contato nos filmes a que assistem e se são influenciados por estas.

Ao tratar da relação das juventudes com o audiovisual, Pacheco (2009), em livro produzido a partir de sua dissertação de mestrado, entende que, a partir dos anos 1990, os filmes sobre jovens estão muito ligados à violência. Segundo a pesquisadora:

Por um lado, para alguns críticos de cinema, este tipo de filme mostra uma juventude baseada em estigmas e mitos, o que contribui para reafirmar uma realidade estigmatizante, através de uma visão estreita, ficcional e espetacular; por outro lado, esses filmes trazem estes assuntos para o debate público, e possibilitam que estes temas façam parte da agenda mediática, abrindo portas para o debate social e o interesse público. (Pacheco, 2009, p. 38). 
A pesquisa etnográfica realizada por Pacheco (2009) numa escola secundária da zona ocidental de Lisboa tinha como objetivo responder às seguintes questões:

[...] pode o cinema interferir na participação da pessoa em relação ao mundo e transformá-la de espectador em participante? Pode o cinema suscitar a reflexão dos jovens sobre suas próprias culturas, experiências, condições de vida, de modo a que a partir dessa reflexão adquiram uma maior capacidade de pensar sobre as próprias experiências? Será que a partir da análise os jovens são estimulados a pensar criticamente sobre suas representações nos media (notícias, telenovela, publicidade)? (Pacheco, 2009, p. 49).

$\mathrm{Na}$ mesma perspectiva de minha pesquisa e da pesquisa de Pacheco (2009), Silva (2007), em sua dissertação de mestrado, analisa como crianças de classes populares do Rio de Janeiro dão sentido a filmes que têm como temática a experiência de crianças dessa mesma classe social. $O$ autor propôs aos alunos a visualização de filmes e a confecção de materiais envolvendo a percepção deles acerca dos filmes que viram, além de registro em diário de campo e gravação das atividades realizadas. Na pesquisa de Silva (2007), os sujeitos envolvidos percebem uma semelhança entre suas vidas e o retratado nos filmes assistidos. Segundo o autor: "Os filmes foram tomados pelas crianças quase que em um registro documental." (p. 143).

É importante destacar que o audiovisual tem enorme relevância tanto no Brasil quanto nos demais países da América Latina, pois faz parte do cotidiano da população latino-americana, entendendo que o audiovisual implica, além de cinema e televisão aberta, os canais de televisão por assinatura e a internet. Partindo da perspectiva de que o audiovisual está presente em diferentes suportes, o que torna mais acessível a visualização de filmes, entendo a importância de pesquisar como os jovens percebem as representações de juventudes que aparecem nos filmes a que eles assistem nos diversos suportes disponíveis.

É possível supor que as trocas culturais das últimas décadas (termo usado por García Canclini em palestra proferida na Casa de Rui Barbosa, no Rio de Janeiro, em 17 de abril de $2015^{4}$ ), ou seja, o uso de novos suportes para interagir com atividades culturais já existentes está fazendo surgir novos tipos de espectadores/receptores de audiovisual. Sendo assim, justifica-se a realização de estudos sobre quem são esses novos receptores e como eles percebem as representações presentes nos filmes assistidos.

\footnotetext{
${ }^{4}$ Disponível em: <https://www.youtube.com/watch?v=QFkfM3ONbfE>. Acesso em: 1ํㅗ. 2015.
} 
Na mesma percepção de García Canclini, Mark Warshaw (2009, p. 10), ao escrever a apresentação do livro "Cultura da convergência", de Henry Jenkins, afirma:

Não é segredo que ocorreu uma mudança de paradigma no modo como o mundo consome as mídias. Ouvimos todo aquele discurso apocalíptico. O comercial de 30 segundo morreu. A indústria fonográfica morreu. As crianças não assistem mais à televisão. As velhas mídias estão na UTI. Mas a verdade é que continuam produzindo música, continuam veiculando o comercial de 30 segundos, um novo programa de TV está prestes a estrear, no momento em que escrevo estas linhas - muitos direcionados a adolescentes. As velhas mídias não morreram. Nossa relação com elas é que morreu. Estamos numa época de grandes transformações $[\ldots]$.

Sarlo (2013), em sua obra "Cenas da vida pós-moderna", afirma que a grande revolução no ato de ver televisão era o zapping, ou seja, a possibilidade de trocar de canal, a partir do controle remoto, o que fez com que o ato de assistir televisão tenha ficado mais dinâmico. As novas tecnologias para assistir filmes e séries e os demais programas de televisão constituem uma nova revolução para produtores e receptores do audiovisual, a maioria deles jovens. Esse contexto sugere a pertinência da realização deste estudo sobre as relações de jovens espectadores com representações de juventude, presentes em filmes com temáticas e personagens juvenis.

\section{1 \\ Objeto e problema de pesquisa}

Esta pesquisa parte do seguinte problema: as narrativas audiovisuais participam da configuração de formas de representação em contextos de alto consumo de imagens em movimento. Tenho interesse em compreender como essas narrativas participam da representação de juventude, na perspectiva de jovens de classes populares, cuja escolha se deu por entender que eles configuram um segmento importante da população que assiste a filmes e, muitas vezes, os filmes são um dos poucos acessos que este público tem à produção cultural. Para os jovens de camadas populares, as mídias estão entre as principais fontes de entretenimento e de informação.

Parti do princípio de que as narrativas audiovisuais produzidas nos EUA ocupam mais de $90 \%$ do circuito exibidor (cinema, televisão e DVD) no Brasil e isso não é diferente quando se trata de narrativas que tematizam as juventudes. Segundo dados da Agência Nacional de Cinema (Ancine), entre as 20 maiores 
bilheterias do ano de 2014, há apenas um filme brasileiro (Até que a sorte nos separe 2, Roberto Santucci, 2013) que ocupa a $17^{\text {a }}$ posição no ranking. O filme mais visto nas salas de cinema brasileiras, em 2014, foi $A$ culpa é das estrelas (Josh Boone, inspirado no romance de John Green, 2014) que estreou em 950 das 2.833 salas de cinema do país e teve um público de 6.165 .705 pessoas (Ancine, 2014). Este é, inclusive, um filme cujos protagonistas são jovens e foi o primeiro filme visualizado na pesquisa de campo para desenvolvimento deste trabalho.

Dos 20 filmes mais vistos nos cinemas em 2014, 10 têm protagonistas jovens, sendo 2 deles filmes infantis (Como treinar seu dragão 2, Dean DeBlois, 2014; Frozen: uma aventura congelante, Chris Buck e Jennifer Lee, 2014).

Ainda segundo dados da Ancine, em 2014, das 584 obras lançadas em DVD no mercado de vídeo doméstico brasileiro, 385 foram produzidas nos Estados Unidos, 56 na França, 51 na Inglaterra, 35 no Brasil, 25 no Canadá, 11 no Japão e $53^{5}$ em outros países. Os dados da agência ainda mostram que, em 2014, dos 284 lançamentos em blu-ray, 206 são de filmes produzidos nos Estados Unidos, 30 na Inglaterra, 19 no Brasil e 13 na França.

Em relação à TV aberta, os 2.233 longas-metragens exibidos no ano de 2014 pelos canais Rede Globo, TV Cultura, TV Brasil, SBT, Band e Rede Record, 1.860 eram estrangeiros e 373 brasileiros (Ancine, 2014). Esse levantamento não apresenta uma relação dos filmes estrangeiros exibidos e nem sua nacionalidade, mas afirma que são os filmes que também tiveram grandes bilheterias nas salas de cinema nos anos anteriores, o que me permite inferir que se trata, em sua maioria, de filmes produzidos nos Estados Unidos.

O contexto descrito me permitiu formular algumas questões que nortearam o presente estudo. A primeira delas diz a respeito a como jovens brasileiros se relacionam com os filmes que têm jovens como protagonistas, a maioria deles produzida em outros países? Como percebem e analisam essas narrativas? Sentem-se representados nelas? Identificam padrões representacionais de juventude? Identificam diferenças nos modelos representacionais? Percebem diferenças nesses modelos entre filmes de uma mesma nacionalidade e entre filmes de nacionalidades diferentes? Identificam estereotipias e originalidades? Formulam hipóteses sobre fatores que influenciam a configuração de formas padronizadas de representação? Na perspectiva dos jovens, filmes que tratam das juventudes influenciam seu(s) modo(s) de ser jovem?

\footnotetext{
${ }^{5}$ Ao fazer a soma dos filmes produzidos em cada país, cheguei a 616 , resultado possível porque há filmes produzidos por mais de um país e foram contados duas vezes.
} 
A partir dessas questões, foram definidos os objetivos da pesquisa.

\section{2}

\section{Objetivos}

Objetivo geral:

- Analisar como os jovens se relacionam com a padronização que o cinema faz da juventude em filmes de grandes bilheterias.

* Objetivos específicos:

- Analisar como os jovens participantes desta pesquisa percebem/analisam as configurações de juventudes nos filmes exibidos para eles, nas atividades realizadas no âmbito da pesquisa, e em filmes que viram em outros momentos.

- Analisar se esses jovens formulam hipóteses sobre os fatores que influenciam a configuração de formas padronizadas de representação de juventudes.

- Analisar se, na percepção deles, filmes que tratam das juventudes influenciam seus modos de ser jovem.

- Analisar se percebem diferenças da configuração das juventudes em filmes de Hollywood e filmes brasileiros.

Esta tese está dividida em sete capítulos. Na apresentação e na introdução, apresentei as motivações para o desenvolvimento deste trabalho. No capítulo 3, trago o referencial teórico, em que os termos destacados são comunicação, juventude e indústria cultural, fazendo a associação desses conceitos com a pesquisa desenvolvida. Os capítulos 4 e 5 apresentam os referenciais metodológicos para o desenvolvimento da pesquisa de campo, além da caracterização do campo selecionado. Os capítulos 6 e 7 são analíticos, nos quais, a partir do material construído durante a pesquisa de campo e à luz do referencial bibliográfico, respondo às questões propostas neste capítulo introdutório. As considerações finais trazem uma síntese dos principais achados de pesquisa. 


\title{
3 \\ Comunicação, indústria cultural e juventudes
}

\begin{abstract}
Se além de uma condição, a "juventude" é também uma construção simbólica inscrita nas práticas sociais, certamente o cinema nos últimos 50 anos constitui um momento importante na constituição dessa arquitetura. Ele tanto é produto dessas representações como produtor de novas formas de percepção desses segmentos. (Spósito, 2009, p. 10).
\end{abstract}

A presente proposta busca discutir a contribuição do audiovisual na representação das juventudes, tomando como referência estudos latinoamericanos da área de comunicação, que analisam o papel do audiovisual na configuração de representações e de modos de ser dos povos latinoamericanos, entre os quais se destacam: Mauro Wilton de Sousa (1995), Jesús Martín-Barbero (2013), Néstor García Canclini (2008a, 2008b), entre outros.

Martín-Barbero \& Rey (2004) assinalam que a "visualidade eletrônica" é hegemônica na América Latina, pois passamos de uma cultura oral para a hegemonia do audiovisual sem ao menos passarmos pela cultura escrita; para estes autores e outros como García Canclini (2008a, 2008b), Sarlo (2013), Orozco-Gomez (1997, 1999, 2005), Vassalo de Lopes (2014), Jacks (1997), Sousa (1995) e Dussel (2010), do campo dos Estudos de Comunicação latinoamericanos, nossa inserção na modernidade se deu através do audiovisual, sendo a televisão o veículo emblemático desse movimento.

Para Martín-Barbero (2013), há uma enorme identificação das massas latino-americanas com a imagem. Em sua perspectiva, as pessoas vão ao cinema, por exemplo, para se verem, se reconhecerem. Há, segundo ele, uma necessidade de entender o real a partir da ficção, um movimento do "desconhecimento ao re-conhecimento da identidade" (p. 171).

Entendo o conceito de identificação expresso por Martín-Barbero, conforme exposto por Freitas (2002, p. 63) embasada por Morin (1958), como sendo a "participação afetiva" estabelecida entre o espectador e o espetáculo. Para a autora, há dois movimentos que prendem o espectador à tela de cinema: a projeção e a identificação. Segundo ela:

A projeção é o meio pelo qual o indivíduo expulsa dele e coloca no outro, pessoa ou objeto, as qualidades, os sentimentos, os desejos, os medos que ele desconhece ou recusa nele mesmo. Já a identificação consiste na assimilação pelo indivíduo de um aspecto, de uma propriedade do outro e a adesão total ou parcial ao modelo desse outro. Por exemplo, logo que o espectador se coloca no lugar do herói de um filme, ele começa a se projetar nele, identificando-se em 
seguida, no momento em que ele, espectador, se imagina na posição desse herói e, enfim, a assimila. (Freitas, 2002, p. 63).

Dessa forma, as imagens do cinema e também da televisão permitem ao espectador a possibilidade de sentir o que o outro sente e assim colocar-se na posição do outro de maneira tão próxima que o espectador, por algumas horas, passa a ser o outro e a viver como tal:

A imagem é, assim, atemporal: ela é do presente do passado e do futuro, mas é somente no tempo presente, com as suas especificidades locais, que os desejos dos espectadores se revelam e que a imagem se atualiza pelo olhar que é dirigido a ela. (Freitas, 2002, p. 63).

Na obra de Martín-Barbero, a televisão ganha enorme destaque, pois, para ele, na América Latina, a cultura televisiva conquistou espaço, principalmente com a telenovela, em sociedades que ainda podiam ser consideradas iletradas. Os povos latino-americanos adentram numa gramática da oralidade visual antes de dominarem, muitas vezes, as narrativas escritas e isso cria certas contradições, como fórmulas narrativas muito rígidas num texto oral, mas cria também algumas particularidades, visto que a cultura latino-americana viria a fixar-se na oralidade e nas imagens para a construção de narrativas.

Segundo este autor, os usos da televisão vão além dos modos de ver TV e são configurados pelos habitus de classe, ou seja, é possível estudar a sociedade a partir da maneira como assiste à TV: "Enquanto uma classe normalmente só pede informação à televisão, porque vai buscar em outra parte o entretenimento e a cultura - no esporte, no teatro, no livro e no concerto - outras classes pedem tudo isso só à televisão." (Martín-Barbero, 2013, p. 303).

Entendo que as narrativas audiovisuais estão presentes em todas as camadas sociais e são estas, para boa parte da população, o principal meio de entretenimento e acesso aos meios culturais. Acredito que este é um tema que precisa ser debatido na área de educação, visto que tão importante quanto ter acesso às diversas mídias, torna-se necessário que os espectadores tenham condições de analisá-las de maneira crítica e reflexiva.

Percebendo o cinema e os meios de comunicação audiovisuais, em geral, como uma via de mão dupla - pois podem criar modelos e transmitir modos de vida, mas podem também ser influenciados pelo público receptor -, proponhome, neste estudo, a discutir as representações de juventudes no audiovisual e a buscar compreender como jovens lidam com elas, a partir dos referenciais teóricos que tratam dos conceitos de cultura e comunicação, construídos em 
uma perspectiva fortemente ancorada na história e nas matrizes culturais latinoamericanas.

Para entender as contribuições das narrativas audiovisuais para o público jovem brasileiro, torna-se necessário compreender a expressão que os meios de comunicação ganharam na América Latina, relacionar a cultura e as identidades latino-americanas que foram construídas a partir da relação do espectador com os meios de comunicação e, a partir disso, entender a relação dos jovens com as culturas e as representações juvenis com estes meios.

Para isso, dividi a apresentação deste capítulo em três partes. A primeira parte - Comunicação, Cultura e Poder - traça um histórico dos estudos sobre a identificação do povo latino-americano com os meios de comunicação de massa. Na segunda parte - Hollywood e a Indústria Cultural - destaco a importância cultural do audiovisual no Brasil e em outros países, além do debate em torno da indústria cultural a partir do cinema hollywoodiano.

$\mathrm{Na}$ terceira parte - Juventudes e jovens espectadores do audiovisual apresento as noções de juventudes e culturas juvenis, ponto central de minha abordagem, partindo do pressuposto de que a ideia de juventude está muito mais ligada a representações do que é ser jovem do que propriamente a fatores etários.

\section{1 \\ Comunicação, cultura e poder}

O campo dos Estudos de Comunicação latino-americanos entende que é impossível pensar em cultura e comunicação sem pensar na recepção, percebendo o receptor como sujeito ativo do processo de comunicação. Os autores desse campo (mencionados na introdução deste capítulo) acreditam que os meios de comunicação de massa (cinema, música, rádio, televisão) tiveram um papel decisivo na formação identitária do povo latino-americano. Segundo Martín-Barbero (2013), a identidade mexicana, a partir dos anos de 1930, passa pelo cinema; a argentina, pelo radioteatro; a brasileira, pela música (o samba) e pela telenovela; e a chilena, pelo jornal.

Para ele, a história dos meios de comunicação na América Latina deve ser registrada como a história do "estudo das mediações através das quais os meios adquiriram materialidade institucional e densidade cultural" (Martín-Barbero, 2013, p. 232). Nesse sentido, abordar os meios de comunicação é abordar 
também as mediações, a cultura e a política de um povo. O autor divide o processo de constituição do massivo, ou seja, dos meios de comunicação de massa, em duas etapas: a primeira, relacionada ao populismo, quando se objetivava criar elos entre os povos de cada país, que foi importante para a formação das identidades nacionais; a segunda etapa, a partir de 1960, seria o período em que os meios de comunicação obtêm mais poderes econômicos e as questões políticas e nacionais ficam em segundo plano. Nesse segundo momento, as questões econômicas e transnacionais ficam mais evidenciadas.

Ao apresentar as relações entre os meios de comunicação massivos e a formação das culturas dos povos latino-americanos, entre 1930 e 1950, MartínBarbero (2013, p. 233) afirma:

[...] o papel decisivo que os meios massivos desempenham nesse período residiu em sua capacidade de se apresentarem como porta-vozes da interpelação que a partir do populismo convertia as massas em povo e o povo em Nação. Interpelação que vinha do Estado, mas que só foi eficaz na medida em que as massas reconheceram nela algumas de suas demandas mais básicas e a presença de seus modos de expressão.

Nesse sentido, é possível dizer que os países latino-americanos também se formam enquanto Nação ao se identificarem com certos elementos da cultura popular, que são trazidos e transmitidos pelos meios de comunicação de massa. É dessa forma, por exemplo, que o Brasil fica conhecido como a terra do samba e do carnaval, motivados pelos programas de rádio da época, o mesmo acontece com o radioteatro argentino, que aposta no melodrama e tem o tango como música de fundo, contribuindo para configurar uma identidade nacional argentina com uma veia para o dramático e emocional.

Segundo Martín-Barbero (2013), enquanto na etapa inicial de entrada dos meios de comunicação na América Latina, existia o pensamento de os meios contribuírem para a criação da ideia de nação, a segunda etapa da constituição dos meios de comunicação de massa aqui foi marcada por estratégias de desenvolvimentismo nos próprios meios. Dessa forma, como a prioridade nesse segundo momento era desenvolver e ampliar as empresas de comunicação, a função social exercida até então pelos meios de comunicação de massa, que consistia na criação de identidades nacionais, ficou em segundo plano, os interesses privados ficaram mais evidenciados. Segundo o autor: "a ideologia se torna agora sim informadora de um discurso de massa, que tem como função fazer os pobres sonharem o mesmo sonho que os ricos" (p. 234).

Nessa mudança de perspectiva, ocorrida a partir de 1960, o receptor passou a ser pensado pela indústria midiática como um consumidor, como um 
sujeito a quem os meios de comunicação vão levar aos sonhos de consumo e de uma vida melhor, abandonando a ideia de nação para pensar no individual e na possibilidade de ascensão social, em que os meios de comunicação se tornam transnacionais e visam essencialmente ao lucro. Nesse segundo momento, o receptor dos meios de comunicação também não é mais o mesmo, ele começa a resistir e mobilizar, é um receptor mais exigente, pois já conhece os meios de comunicação e começa a desenvolver uma visão mais crítica deles.

Segundo palavras de Martín-Barbero, em entrevista ao Programa RodaViva da TV Cultura, exibido em 22 de outubro de $2002^{6}$ : "O controle pelos meios de comunicação aumentou com a globalização, mas ainda há brechas. [...] Nunca os meios de comunicação irão controlar os espectadores o quanto acham que controlam." Seguindo esta mesma lógica, García Canclini (2008b) afirma que os próprios receptores usam da mídia para chamar atenção para questões sociais, por exemplo, ao fazerem manifestações de rua para aparecerem nos noticiários da TV, o que indica que o receptor já conhece melhor o meio e, a partir das brechas, cria novos espaços de expressão de suas ideias.

Porém, vale ressaltar que é importante os sujeitos serem educados e formados para entender a linguagem e a perspectiva dos meios de comunicação e da indústria cultural; além disso, é preciso ter em mente que se o espectador muda, a linguagem também muda, ou seja, é necessário uma atualização constante dos espectadores, pois a indústria cultural se recicla cotidianamente. Nas palavras de Martín-Barbero (2000, p. 58):

O cidadão de hoje pede ao sistema educativo que o capacite a ter acesso à multiplicidade de escritas, linguagens e discursos nos quais se produzem as decisões que o afetam, seja no campo de trabalho como no âmbito familiar, político e econômico. Isso significa que o cidadão deveria poder distinguir entre um telejornal independente e confiável e um outro que seja mero porta-voz de um partido ou de um grupo econômico, entre uma telenovela que esteja ligada ao seu país, inovando na linguagem e nos temas e uma telenovela repetitiva e simplória. Para tanto, necessitamos de uma escola na qual aprender a ler signifique aprender a distinguir, a tomar evidente, a ponderar e escolher onde e como se fortalecem os preconceitos ou se renovam as concepções que temos sobre política, família, cultura e sexualidade.

Nesse sentido, caberia à escola ensinar outras linguagens que vão além da língua oficial do país. É preciso que se aprenda nas escolas as linguagens ligadas ao audiovisual e às tecnologias, ou seja, é necessário que ocorra uma literacia digital e fílmica/audiovisual. Conforme Kellner \& Share (2008, p. 689690):

\footnotetext{
${ }^{6}$ Disponível em: <https://www.youtube.com/watch?v=fiPo2yGOMf8>. Acesso em: 28 ago. 2015.
} 
No contexto da contínua expansão da transformação tecnológica e econômica, a alfabetização crítica da mídia é um imperativo para a democracia participativa, pois as novas tecnologias de informação e comunicação, associadas a uma cultura de mídia com base no mercado, fragmentaram, conectaram, convergiram, diversificaram, homogeneizaram, estabilizaram, ampliaram e remodelaram o mundo. Essas mudanças estão reconstruindo a maneira como as pessoas pensam e reestruturando as sociedades, nos níveis local e global.

Na perspectiva dos Estudos da Comunicação latino-americanos, o receptor ganha destaque e não é visto apenas como aquele que recebe a informação, ou, nas palavras de Sousa $(1995$, p. 23): "O receptor se confunde ora com o consumidor social ora com o desbravador de si mesmo: é um consumidor que não se resume a depositário sedento do irrefletido de desejos, nem à busca desesperada de si". Mas para que isso de fato ocorra, é preciso investir na formação deste receptor/consumidor/cidadão.

A partir da concepção de que o receptor se confunde com o produtor, visto que dá subsídios para criação de produtos comunicacionais, é que apresento os conceitos e discussões que me levaram a analisar as representações de juventudes na interação de jovens com narrativas audiovisuais. Entendo os meios de comunicação como um espelho que pode refletir a cultura, mas que também pode deixar-se refletir por ela.

Nessa perspectiva, compreendo a relação entre mídia e espectador a partir do que Sarlo (2013, p. 105) comenta sobre a lógica do encontro entre espectador e televisão:

Mimética e ultrarrealista, a televisão constrói seu público a fim de poder refleti-lo, e o reflete para poder construí-lo: no perímetro desse círculo, a televisão e o público estabelecem o pacto de um programa mínimo, tanto do ponto de vista estético quanto do ponto de vista ideológico. Para produzir-se como televisão, basta ler o livro da televisão. Depois o público usa a televisão como lhe parece melhor, ou como pode; e a televisão não deixa de fazer o mesmo. O mercado audiovisual, que ficcionaliza a todos como iguais, reside neste pacto que não é necessário às possibilidades técnicas do veículo, e sim à lei capitalista da oferta e da procura.

Essa compreensão aponta ainda para as possíveis interseções entre política e cultura que, segundo Martín-Barbero (2013), estão no cerne da constituição do público receptor latino-americano. Para o autor, a população conquistou, nas últimas décadas, a capacidade de não apenas assistir aos produtos veiculados pelos meios de comunicação, mas também de analisar e contestar estes meios; o receptor se percebe não só como alguém que vê, mas que quer conhecer a técnica e manipulá-la, hibridizando visualidade e tecnicidade (Martín-Barbero \& Rey, 2004, p. 16).

Segundo García Canclini (2008b, p. 51): "Os textos e as imagens vão existindo à medida que o leitor ou o espectador os usam ou reinterpretam." As 
funções de receptor e produtor se complementam, pois em ambas há ação e estão aí as chamadas "brechas" que permitem o aparecimento de discursos contraditórios nos meios de comunicação para atender à diversidade de seu público receptor.

Nessa mesma direção, García Canclini (2008b) esclarece que o consumidor pode ser considerado o receptor, ou ainda, o usuário de um serviço ou de produtos culturais que foram absorvidos pela Indústria Cultural. O autor assinala, no entanto, que a diminuição da pluralidade de ofertas pode tornar o consumidor mais susceptível ao discurso hegemônico dos meios. Pode parecer contraditório afirmar a diminuição da pluralidade de ofertas em um contexto de ampliação de possibilidades de acesso à produção midiática, com canais de TV por assinatura, repositórios de vídeo e produtos audiovisuais disponíveis na internet. No entanto, os meios de comunicação seguem sendo comandados por poucas e gigantescas corporações, a maioria delas sediadas nos EUA, que, de certo modo, ainda determinam padrões estéticos ${ }^{7}$, ideológicos ${ }^{8}$ e narrativos ${ }^{9}$. García Canclini (2008b, p. 20) exemplifica isso ao tratar dos campos culturais como mercado:

\begin{abstract}
A fusão de empresas acentua essa integração multimídia e a sujeita a critérios de rentabilidade comercial que prevalecem sobre a pesquisa estética. Um dos exemplos mais citados é o grupo Time: dedicado à mídia impressa, uniu-se ao mega-produtor audiovisual Warner. Transformados, assim, nos maiores fabricantes de espetáculos e conteúdos (Time-Warner), em 2000 aliaram-se a um mega-provedor da internet (AOL). Por outro lado, a empresa Cobis Corporation, de Bill Gattes, ao comprar mais de vinte milhões de imagens fotográficas, pictóricas e de desenhos, acrescenta, a seu controle digital de edição e transmissão, a gestão exclusiva de uma enorme parte da informação visual sobre arte, política e guerras. Logo, essas corporações concentram a capacidade de selecionar e interpretar os acontecimentos históricos.
\end{abstract}

Segundo o autor, há uma transformação do consumidor em cidadão, ao lutar por melhores condições de uso e acesso aos bens culturais. Porém, ao discorrer sobre a cidadania, García Canclini (2008b, p. 29) alerta que:

[...] faltam aos movimentos de consumidores, de telespectadores, formas de representação de cidadãos como a do ombudsman dos direitos comunicacionais e culturais. Poucos jornais em castelhano têm a figura do defensor do leitor. $\mathrm{Na}$ televisão, vários países europeus moderam o tempo da publicidade e a espetacularização violenta dos conflitos íntimos e dos dramas sociais por meio de

\footnotetext{
7 Neste trabalho, uso o conceito clássico de estético que vem do grego aisthésis: percepção, sensação, sensibilidade, diretamente ligado aos fundamentos da arte.

${ }^{8}$ Ao tratar de termos como "ideologia" e "ideológico" o farei a partir de Althusser (1996, p. 114), que cita os três pilares da ideologia: 1) "a ideologia é uma 'representação' imaginária dos indivíduos com suas condições reais de existência"; 2) "a ideologia tem uma existência material"; 3) "a ideologia interpela os 'indivíduos' como sujeitos".

9 O termo "narrativa", neste trabalho, tem o significado de exposição de fatos ou formas de contar histórias.
} 
conselhos de cidadãos ou integrados por diversos setores (governo, sociedade civil, empresas de comunicação e criadores). Os governos e empresários latinoamericanos rejeitam essas ações, invocando uma suposta capacidade de autoregulação ética dos canais, embora sua trajetória mostre dificuldades para situar a caça aos espectadores dentro de normas públicas. Continuamos esperando a tradução midiática de uma descoberta do século passado: o fato de que a democratização da sociedade não passa unicamente por rotinas eleitorais ou outros comportamentos expressamente políticos.

É importante destacar que, apesar da falta de políticas mais incisivas que regulem os meios de comunicação, os próprios usuários têm criado caminhos alternativos que apontam para uma regulação de mercado, os meios audiovisuais são uma prova disso: se até bem pouco tempo atrás contávamos apenas com a televisão e o cinema, hoje são múltiplas as possibilidades de acesso às produções audiovisuais, pois além da TV aberta e salas de cinema, tem-se a possibilidade de assistir aos canais por assinatura e utilizar, como consumidor e/ou como produtor, os repositórios de vídeos da internet.

Em palestra proferida na Casa de Rui Barbosa, no Rio de Janeiro, em 17 de abril de 2015, García Canclini afirmou que a cada aparição de um novo suporte midiático, acredita-se que o anterior acabaria, porém, o que se percebem são novas possibilidades e suportes para assistir a velhas narrativas. As salas de cinema não fecharam com o aparecimento da TV, e ambos não perderam totalmente seu público com a disseminação das videolocadoras ou os filmes disponíveis na rede mundial de computadores.

Assim como García Canclini, Jenkins (2009, p. 41-42) acredita que: "Os velhos meios de comunicação não estão sendo substituídos. Mais propriamente, suas funções e status estão sendo transformados pela introdução de novas tecnologias." Este autor afirma, ainda, que as mudanças estão relacionadas à ideia de protocolos, cunhada por Lisa Gitelman, que trata, grosso modo, do vínculo que estabelecemos com cada suporte midiático, podendo sofrer mudanças a todo o momento. Para Jenkins (2009), ao tratar deste conceito, cada espectador ou usuário estabelece diferentes vínculos com os suportes e estes mudam. Por exemplo, um espectador pode acompanhar em canal aberto uma determinada telenovela, porque gostou do tema, porque está de férias ou porque gostou da atuação de algum ator e tem tempo para isso; ao acabar a telenovela ele não se vê obrigado a acompanhar a próxima, mesmo que neste horário ele não tenha compromisso que o impeça de ver TV. O mesmo acontece com as redes sociais, o usuário pode acompanhar por um tempo, depois sair e, se quiser, mais tarde, volta a fazer parte dela, pois não há nada que o impeça de fixar-se àquele suporte. 
Todas essas tecnologias convivem simultaneamente, uma não exclui a outra e são espaços e ferramentas importantes para disseminação cultural. Beatriz Sarlo (2013) defende que a novas tecnologias criam novas maneiras de leitura, que não é mais apenas a leitura de letras, mas uma leitura dos sons, das imagens, permitindo diversos leitores sociais possíveis.

Porém, vale ainda destacar que as escolhas entre um ou outro suporte, uma tecnologia ou outra, não são tão autônomas quanto parecem, o mercado influencia as escolhas e as condições socioeconômicas do usuário também definem o suporte por ele usado. Nesta perspectiva, a seção seguinte discute as relações entre a indústria cultural e o mercado cinematográfico.

\section{2 \\ Hollywood e a indústria cultural}

Conforme apresentei na introdução deste trabalho, a indústria cinematográfica estadunidense é extremamente poderosa e os filmes produzidos em Hollywood são lançados quase que simultaneamente no mundo inteiro, atingindo grandes bilheterias e servindo como modelo e inspiração também para filmes de grandes bilheterias locais. Além disso, são esses filmes, considerados de sucesso, visto que são assistidos por um grande público, que são lançados em DVD, transmitidos pelos canais de TV fechados e, mais tarde, pelos canais abertos.

Ao referir-se à oferta de músicas e filmes na televisão, nos vídeos e na internet, García Canclini (2015, p. 238) entende que:

A enorme capacidade das majors de Hollywood - Buena Vista, Columbia, Fox, Universal e Warner Bros. - para manejar combinadamente os circuitos de distribuição nesses três meios, em todos os continentes, permite-lhes controlar a quase totalidade dos mercados em benefício de suas produções. A Índia é o único país de grandes dimensões que resiste, concedendo aos filmes estadunidenses só $4 \%$ do tempo de exibição. Até na Europa, onde vários países tratam de diminuir o impacto estadunidense e preservar a diversidade cinematográfica com subvenções à produção e cotas para a difusão, aproximadamente $70 \%$ das salas são ocupadas por filmes de Hollywood.

É importante, ainda, mencionar que a indústria de cinema é a terceira que mais arrecada nos Estados Unidos, perdendo apenas para a indústria armamentista (que arrecadou 150 bilhões de dólares em 2011), segundo dados 
da "Revista Exame"10 e para a de tecnologia - incluindo nesta os jogos de computadores. A arrecadação anual dos filmes produzidos em Hollywood é de cerca de 40 bilhões de dólares, sendo que em 2015, foram 11 bilhões apenas em bilheterias, conforme notícia do site $\mathrm{UOL}^{11}$. Segundo dados do site Motion Picture Association of America ${ }^{12}$ (MPAA), da associação de cinema americana que representa as seis maiores companhias de cinema de Hollywood (Disney, Paramount, Sony Pictures, 20th Century Fox, Universal e WB), a indústria de filmes e TV estadunidense é constituída por 88 mil empresas e gera 17 bilhões em exportações em todo o mundo. É necessário ainda mencionar que, desde os anos 1950, as grandes corporações passaram a controlar a indústria cinematográfica dos Estados Unidos e os setores da mídia, o que se traduz num controle sobre a veiculação dos filmes produzidos, além dos produtos que frequentemente acompanham esses filmes.

As seis companhias mencionadas são as maiores e dominam o mercado de filmes, tanto nos Estados Unidos quanto no restante do mundo. Sendo assim, em função desse domínio no processo de produção, veiculação e circulação dos filmes, a indústria cinematográfica é dominada por uma única maneira de fazer filmes, levando-se em conta os gêneros, desta forma, os filmes de horror, de guerra, as comédias, os musicais e outros têm suas convenções. Existe, portanto, uma padronização na forma de fazer filmes, principalmente os que obtêm grandes bilheterias. Segundo Champangnatte (2016, p. 416):

\begin{abstract}
A atividade cinematográfica é composta de três etapas: a produção, a distribuição e a exibição. A primeira refere-se à criação do filme por parte de uma produtora. A segunda, à copiagem e à distribuição das cópias pelas salas de cinema, por parte das distribuidoras. A terceira etapa refere-se à exibição dos filmes para o público, realizada pelas salas de cinema. Então, para um filme chegar ao cinema, ele precisa passar por essas três instâncias e cada uma delas demanda um investimento elevado.
\end{abstract}

Os altos investimentos financeiros desses filmes não são feitos aleatoriamente, por isso, dificilmente o mercado cinematográfico investe em projetos muito ousados, há pesquisas de mercado para atender a certas demandas. Os filmes são feitos pensando em determinado público-alvo. Conforme analisa Matta (2008), a segmentação de público ocorrida no cinema a partir do pós-guerra fez surgir, nos anos 1970, os filmes chamados

\footnotetext{
${ }^{10}$ Disponível em: <https://exame.abril.com.br/revista-exame/a-industria-de-150-bilhoesm0051720/>. Acesso em: 15 jun. 2017.

${ }_{11}$ Disponível em: <https://cinema.uol.com.br/noticias/redacao/2015/12/30/hollywood-bate-recordehistorico-e-fatura-us-11-bilhoes-em-2015.htm>. Acesso em: 15 jun. 2017.

${ }^{12}$ Disponível em: <http://http://www.mpaa.org/>. Acesso em: 20 jun. 2016.
} 
blockbusters $^{13}$; destinados ao público jovem, entre 14 e 24 anos, este tipo de filme, além de pensar na produção, investe muito no marketing. Segundo o autor:

\begin{abstract}
A evolução das estratégias de lançamento de blockbusters fez surgir um novo conceito de salas de exibição: o sistema multiplex - complexo de exibição, contando com um conjunto de salas num mesmo empreendimento comercial, onde se pode auferir receitas também com a concessão de serviços acessórios, como com a venda de lanches ou a exploração de máquinas de jogos. $\mathrm{O}$ modelo multiplex permitiu maior eficiência e eficácia nos lançamentos mundiais dos blockbusters. Com o avanço tecnológico e surgimento de novas mídias que compuseram a indústria audiovisual, os lançamentos da indústria cinematográfica desenvolveram a estratégia de windowing. Nela, as salas de cinema assumem a posição de mercado primário de exibição. Após serem comercializados nos cinemas nacionais e estrangeiros, os filmes são revendidos para os mercados subseqüentes com baixos custos adicionais, atingindo, passo a passo, as diversas janelas de exibição caseiras: pay per views, vídeos e DVDs, TVs pagas, TVs abertas nacionais e estrangeiras e quaisquer outras mídias (transmissões via internet, telefones celulares, etc.). (Matta, 2008, p. 13).
\end{abstract}

Os dados trazidos por Matta (2008) demonstram que os filmes que atingem grandes bilheterias são também aqueles que chegam mais rápido a outros suportes e são abalizados pelos resultados de outras pesquisas, tais como as realizadas por Sacramento (2008) e Duarte (2008) que apontam que a relação de crianças e jovens com o audiovisual se estabelece essencialmente a partir da TV aberta que exibe, principalmente, os filmes estadunidenses de grandes bilheterias.

O que foi apontado por Matta (2008) e Champangnatte (2016) pode ser sintetizado nas palavras de García Canclini (2015 p. 245-246):

\begin{abstract}
No campo cinematográfico, o predomínio mundial do cinema estadunidense do pós-guerra em diante converteu-se em oligopólio a partir da década de 1980, ao controlar simultaneamente a produção, distribuição e a exibição em mais de uma centena de países. Numa operação mais expansiva do que em qualquer outro campo cultural, Hollywood impôs um formato de filmes quase único: produções de mais de 10 milhões de dólares - nas quais mais da metade de orçamento destinase a marketing -, com preferência pelos gêneros de ação (thrillers, policiais, aventuras, catástrofes e guerras) com temas de fácil repercussão em todos os continentes.
\end{abstract}

Em 1947, quando escreveu sobre a indústria cultural, Theodor Adorno tinha como referência o rádio e o cinema, que eram as duas mídias de maior alcance na época. Para o filósofo, estes não tinham mais necessidade de serem definidos como arte, visto que, naquele período, já eram negócios rentáveis e serviam para vender uma ideologia. O criador da Escola de Frankfurt afirmava que o cinema, o rádio (e aqui se pode inserir a TV, meio de comunicação ainda

\footnotetext{
${ }^{13}$ Blockbuster é uma palavra de origem inglesa que indica um filme (ou outra expressão artística) produzido de forma exímia, sendo popular para muitas pessoas e que pode obter elevado sucesso financeiro.
} 
não disseminado no período de seus estudos), são parte integrante da indústria cultural. Segundo ele:

Os interessados adoram explicar a indústria cultural em termos tecnológicos. A participação de milhões em tal indústria imporia métodos de reprodução que, por seu turno, fazem com que inevitavelmente, em numerosos locais, necessidades iguais sejam satisfeitas com produtos estandardizados. [...] Os clichês seriam causados pelas necessidades dos consumidores: por isso seriam aceitos sem oposição. Na realidade, é por causa desse círculo de manipulações e necessidades derivadas que a unidade do sistema torna-se cada vez mais impermeável. (Adorno, 2015, p. 8-9).

Ao tratar da relação do espectador com a indústria cultural, Adorno (2015, p. 27) afirma que esta se adapta aos desejos por ela evocados, enquanto o espectador "se satisfaz com a reprodução do sempre igual". Na perspectiva de Adorno, a indústria cultural, aqui representada principalmente pelo cinema estadunidense, já conhece o público que assiste a filmes e lança produtos para atender a ele, portanto, não há mudanças muito profundas na estrutura das narrativas audiovisuais. Martín-Barbero (2013), ao tratar do cinema estadunidense no final da Primeira Guerra, aponta para a mesma direção de Adorno. Para ele, "os artistas foram controlados por aquilo em que os produtores acreditavam, os distribuidores foram controlados por aquilo em que os exibidores acreditavam, e estes por aquilo que o público desejava." (Martín-Barbero, 2013, p. 203).

O filme A culpa é das estrelas (Josh Boone, 2014), um dos filmes visualizados na pesquisa de campo, estreou no Brasil em 5 de junho de 2014 e teve a maior bilheteria no país nesse ano; nove meses depois, estreou em canal fechado (Telecine Premium), em horário nobre, e em 29 de setembro de 2016 estreou no horário nobre de filmes da Rede Globo (canal aberto), batendo o recorde de audiência (26 pontos).

A partir do exemplo deste filme, é preciso entender que mesmo com novos suportes, a TV aberta ainda é responsável pelo entretenimento do público brasileiro e, na maioria das vezes, o que chega até ela são os filmes de grandes bilheterias estadunidenses. Dessa forma, torna-se essencial compreender a contribuição do audiovisual para a formação cultural brasileira, e investigar como isso afeta as juventudes que estão imersas nessas formas de visualidades. 


\section{3 Juventudes e jovens espectadores do audiovisual}

Em pesquisa sobre a cultura das juventudes argentinas no início da década de 1990, Sarlo (2013, p. 49) afirma que juventude é uma "estética da vida cotidiana". Segundo a autora, é possível notar os estilos juvenis a partir das roupas que os jovens usam, dos modos de andar, dos modos de se relacionar com os outros em qualquer rua de Buenos Aires. Existem, para a autora, culturas juvenis ou modos de ser jovem, que não é uma característica apenas da Argentina, é possível perceber essa "estética" em todos os lugares do mundo.

García Canclini (2015, p. 209), na mesma direção de Sarlo, aponta:

Um avanço notório no conhecimento sobre juventude foi indagar o que significa ser jovem não como uma pergunta geracional, e menos ainda, pedagógica ou disciplinar. Quero examinar em que sentido é uma pergunta social, ou seja, uma averiguação sobre o sentido intercultural do tempo.

Dessa forma, minha preocupação, assim como a de García Canclini, é entender quais representações de juventudes são possíveis hoje a partir das relações estabelecidas com os meios de comunicação e, mais especificamente com audiovisual. Segundo o autor, referindo-se aos jovens da década de 1990:

Os jovens atuais são a primeira geração que cresceu com a televisão em cores e o vídeo, o controle remoto, o zapping e - uma minoria - com o computador pessoal e a internet. Entre as décadas de 1970 e 1980, a pergunta era o que significava ser a primeira geração na qual a televisão era componente habitual da vida familiar. Agora se trata de entender como a espetacularização permanente à distância modifica, ou, dito de outro modo: essa estranha combinação de midiatização e interconectividade. A midiatização afasta, esfria e, ao mesmo tempo, a interconectividade proporciona sensações de proximidade e simultaneidade. (García Canclini, 2015, p. 216).

Posso acrescentar que os jovens dos anos 2000, além do controle remoto, contam com a internet para ter acesso ao audiovisual. Mesmo que exista uma diferença de acesso entre as diferentes classes sociais, hoje há maiores possibilidades de conexão do que nas décadas de 1970 a 1990.

Ao traçar um histórico da criação da juventude, Savage (2009) afirma que essa fase da vida por muito tempo foi ignorada como sendo um hiato entre a infância e a idade adulta. Segundo o autor, é no século XIX que começa a aparecer uma literatura autobiográfica que aponta para representações de juventudes; antes dessa época, as juventudes eram silenciadas, deixadas num limbo social, os jovens ou eram vistos como crianças ou como adultos precoces.

Para o autor, a partir da obra "Emílio", de Rousseau (1762), dos poemas de Rimbaud (a partir de 1870, França), do lançamento do diário de Marie 
Bashkirtseff (em 1887, França), da divulgação das cartas do jovem assassino Jesse Pomeroy (entre 1885 e 1887, Estados Unidos), do lançamento do livro "O retrato de Dorian Gray", de Oscar Wilde (1890, Inglaterra) começaram a circular as questões que afetavam a juventude e que estavam ligadas a elementos como sexualidade, medo do futuro, vontade de viver intensamente o presente, contato com o álcool e as drogas, individualismo exacerbado, entre outros elementos. Ao ter contato com esses escritos, a aristocracia europeia da época percebeu características de uma delinquência que precisava ser contida.

Em função dessa preocupação da aristocracia, a juventude começou a receber mais atenção dos governos, no sentido de manter os corpos mais disciplinados, além de escolas públicas, para manter a elite mais tempo nas instituições, longe dos perigos das ruas e do contato com um mundo considerado perverso.

Segundo Savage (2009), nesse período, aumentou o número de crimes cometidos por jovens, tanto nos Estados Unidos quanto na Europa, o que levou as autoridades a criarem instituições prisionais para esse segmento social, além de escolas para ensinar ofícios para a classe operária. Além disso, muitos jovens ingressavam no mercado de trabalho, tornando-se consumidores e, a partir daí, vários produtos seriam destinados a esse público. Nas palavras de Savage (2009, p. 82):

O termo definitivo para o longo hiato entre infância e idade adulta foi cunhado por
um psicólogo chamado G. Stanley Hall. Durante o ano de 1898 , ele lutou para
completar o seu imenso compêndio sobre a segunda década da vida. Ele vinha
coletando dados havia no mínimo cinco anos e, numa conferência naquele verão,
ele deu a sua primeira definição de idade para o que chamou de "adolescência". A
sua grande realização foi perceber que, na sociedade americana e ocidental, o
estado intermediário do que Rousseau havia ao mesmo tempo exaltado e feito
advertência a respeito, não era só determinado biologicamente, mas socialmente
construído.

A perspectiva da juventude como algo construído social e culturalmente é defendida por Sarlo (2013), Reguillo (2003), Dayrel (2003, 2007), Carrano (2014) e outros que entendem as juventudes como múltiplas e suas representações partem de seus contextos sócio-históricos.

Ao abordar a temática da juventude, é importante entender que, na contemporaneidade, existem inúmeras maneiras de ser jovem, que passam pelas condições sociais, culturais, de gênero, além das questões espaciais e geográficas, o que me leva a referir-me a juventudes, usando o termo no plural. Conforme Dayrel \& Carrano (2014, p. 104), "não podemos trabalhar com a noção 
de que existe uma juventude, pois são muitas as formas de ser e experimentar o tempo de juventude. Assim, digamos: JUVENTUDES."

Segundo Dayrel (2007, p. 113-114):

[...] é cada vez mais difícil definir modelos na transição para a vida adulta. As trajetórias tendem a ser individualizadas, conformando os mais diferentes percursos nessa passagem. Podemos dizer que, no Brasil, o princípio da incerteza domina o cotidiano dos jovens, que se deparam com verdadeiras encruzilhadas de vida, nas quais as transições tendem a ser ziguezagueantes, sem rumo fixo ou predeterminado.

Assim como Dayrell $(2003,2007)$, entendo que a juventude é um tipo de representação e, ao mesmo tempo, uma condição social. É possível falar na fase da juventude como um momento de transformação física e psicológica, maior independência e autonomia dos sujeitos em relação à família, à escola e às possibilidades de estar no mundo, mas, ao mesmo tempo, cada jovem exercerá essa autonomia à sua maneira e de acordo com as suas possibilidades. Nesse sentido, cada trajetória será feita de maneira diferente, fazendo com que cada jovem tenha um percurso singular.

Neste trabalho, não faço um recorte de juventude ligado a uma determinada faixa etária, sigo a perspectiva proposta por Enne (2014, p. 135): "Juventude, embora ainda apareça associada a uma faixa etária em algumas leituras, é agora uma forma de ver e ser no mundo [...]." Além disso, este trabalho traça um panorama sociológico das juventudes, sendo assim, conforme Dayrell \& Carrano (2014, p. 109):

De uma forma genérica, podemos afirmar que, nesse contexto, a psicologia tende a utilizar a noção de adolescência na perspectiva de uma análise que parte do sujeito particular e de seus processos de transformação. Já as Ciências Sociais, em especial a Sociologia e a Antropologia, tendem a utilizar-se da noção de juventude se centrando nas relações sociais passíveis de serem estabelecidas por sujeitos ou grupos particulares nas formações sociais, no processo de traçar vínculos ou rupturas entre eles.

Ainda, segundo esses autores:

A definição da juventude por idade encontra elementos objetivos no aspecto da maturidade biológica e sua delimitação se reveste de importância para as políticas públicas, notadamente quando se pensa em contagem de população, definição de políticas e recursos orçamentários. Compreender os jovens apenas pelo fator idade, contudo, seria simplificar uma realidade complexa que envolve elementos relacionados aos campos simbólico e cultural e aos condicionantes econômicos e sociais que estruturam as sociedades. (Dayrell \& Carrano, 2014, p. 110).

Ainda nessa mesma direção, o estudioso italiano Massimo Canevacci (2005) caracteriza os jovens como intermináveis; segundo ele, não se pode reduzir a idade a um ciclo, o jovem à taxa demográfica: "Cada jovem, ou melhor, 
cada ser humano, cada indivíduo pode perceber sua condição de jovem como não-terminada e inclusive como não-terminável." (Canevacci, 2005, p. 29).

É necessário frisar que ao tratar de juventudes é importante não criar determinados estereótipos ou ideias que muitos já cristalizaram. Dayrell (2003) afirma que muitos estudos acabam fazendo recortes de juventudes, algumas vezes, apresentando o jovem e a juventude em apenas um contexto. Segundo o autor, há aqueles que veem esta fase como a da transitoriedade, passando a ideia do "vir a ser", ou seja, o jovem ainda não exerce de fato um papel social, está se preparando para tal; outros entendem a juventude como período da liberdade, em um ideal romântico, como tempo das experimentações sem compromissos. Há ainda um terceiro grupo que concebe a juventude apenas no campo da cultura, além de outro grupo que analisa a juventude sob o prisma da crise de personalidade. Todos esses recortes caminham para a criação de um modelo, mas não dão a real dimensão do que sejam as juventudes.

Cabe destacar que, ao me referir aos jovens como sujeitos sociais, entendo-os em seus processos de constituição e suas relações com o mundo que os cerca, por isso, as representações juvenis são tão diversas, pois expressam a diversidade dos contextos em que cada um está inserido e como esta inserção se dá.

Na mesma linha de Dayrell $(2003,2007)$, Carrano $(2014$, p. 3) aponta que: "Uma das questões mais impactantes para a educação escolar tem sido o reconhecimento de que o aluno é também um jovem" e, sendo assim, cabe à escola e a outras instituições, como a própria família, perceber as diversas formas de ser jovem no mundo atual.

Segundo Carrano \& Brenner (2017, p. 441):

As realidades juvenis são vivências de relacionamentos, tramas sociais, oportunidades abertas, interdições experimentadas e narrativas sobre segregações em múltiplas experiências de espaços-tempos. As práticas sociais podem ser incorporadas a um conceito ampliado de educação, uma vez que essas compreendem em suas dinâmicas culturais próprias de realização a formação de valores, a troca de saberes e, em última instância, a própria constituição da subjetividade.

Sarlo (2013) argumenta que existe certa pressão para levar os jovens a parecerem iguais, tentando criar uma única identidade juvenil e isso se dá, muitas vezes, inclusive por pressões do mercado, que tenta criar um consumidor ideal. Para a autora, os meios de comunicação de massa, tendo como ideal a indústria cultural e de consumo, são capazes de criar gostos que vão além das atividades culturais juvenis, estabelecendo maneiras de ser jovem e de se 
socializar com os outros a partir das atividades culturais. Um exemplo disso, para ela, é a cultura do rock, cuja expressão vai muito além da música.

As juventudes contemporâneas convivem, frequentemente, com culturas que vão além de determinado elemento: na música, por exemplo, o hip-hop e o funk, nas narrativas, é interessante notar uma convergência midiática: filmes que viram jogos, livros que viram filmes e com isso, criam-se ídolos, modos de se vestir e afinidades com outros fãs, além de maneiras de colocar-se no mundo a partir desses elementos midiáticos. Para Sarlo (2013, p. 54): "O mercado ganha relevo e corteja a juventude, depois de instituí-la como protagonista da maioria de seus mitos."

Na mesma direção de Sarlo (2013), Enne (2014, p. 132) afirma: “a criação da categoria de juventude, dentro do processo da modernidade está intrinsecamente ligada à criação, consolidação e desenvolvimento da indústria cultural e dos aparatos tecnológicos que a envolvem."

Ao tratar das juventudes e das mídias, Enne (2014) acredita que seja essencial tratar da cultura juvenil do consumo; para a autora, essas três categorias "são fundamentais para pensarmos a cultura globalizada contemporânea, bem como os processos de construção e desconstrução das identidades pessoais e coletivas" (p. 132).

A autora discorre, ainda, que a eletricidade permitiu o surgimento de uma cultura de massa e, consequentemente, dos meios de comunicação de massa, representados pela $\mathrm{TV}$, cinema e rádio e, mais recentemente, pelos meios digitais (ou www), e que esta pode ter um potencial democratizador ou pode ser uma poderosa ferramenta de dominação. Segundo a autora, apesar dos limites de acesso e mesmo cognitivos, as novas mídias podem oferecer um caminho mais aberto para os sujeitos, em especial para as juventudes, visto que estes estão "mais ambientados com esse novo arsenal tecnológico" (Enne, 2014, p. 133).

Ao tratar da convergência das mídias, Jenkins (2009) aponta para uma visão parecida com a de Enne (2014); para ele, o público mais captado por este fenômeno de mercado são as juventudes e, dessa forma, para o mercado produtor de artefatos culturais, estes são vistos como consumidores em potencial de vários suportes midiáticos. Portanto, quando não é possível igualálos, é necessário diferenciá-los para a criação de nichos. Ao explicar o processo de transmídia ocorrido com o filme e todos os produtos de Matrix (EUA, 1999, irmãos Wachowski), o autor afirma: 
Mídias diferentes atraem nichos de mercado diferentes. Filmes e televisão provavelmente têm públicos mais diversificados; quadrinhos e games, os mais restritos. Uma boa franquia transmídia trabalha para atrair múltiplas clientelas, alterando um pouco o tom do conteúdo de acordo com a mídia. Entretanto, se houver material suficiente para sustentar as diferentes clientelas - e se cada obra oferecer experiências novas - é possível contar com um mercado de intersecção que irá expandir o potencial de toda franquia. (JENKINS, 2009, p. 138-139).

A partir do conceito de transmídia, é possível entender que, para muitos, as juventudes são grupos de consumidores em potencial e são analisadas para inserirem-se em diferentes nichos da indústria cultural.

Dayrell (2007) amplia essa definição de juventudes e pontua que as constituições dessas se dão na escola, no trabalho, na família, nas socializações, nas atividades culturais, além da estrutura socioeconômica de cada um. Entendo que essas constituições se imbricam o tempo todo, por isso, muitas vezes, torna-se difícil analisá-las isoladamente, posto que as socializações, por exemplo, envolvem todos os outros elementos: escola, trabalho, família, cultura e condições sociais, ao mesmo tempo em que acredito que as atividades culturais podem ocorrer na escola, ou em função da socialização, ou seja, nos grupos de que esses jovens fazem parte.

Carrano \& Fávero (2014, p. 11), no prefácio do livro do qual são organizadores, afirmam:

\begin{abstract}
A temática "juventude" alcançou maior visibilidade nos últimos quinze anos no Brasil como produto da intersecção de vários domínios da vida social e da ação de diferentes atores. Os jovens entram na pauta das políticas públicas como parte da questão social e do crescimento da violência no país. Iniciativas também observadas nesse período, em um primeiro momento nas prefeituras e posteriormente em âmbito federal, tentam trazer para a arena pública novas visibilidades em torno dos segmentos juvenis, considerados como atores capazes de agir e promover interlocução política.
\end{abstract}

Os autores ainda esclarecem que o estudo das juventudes não representa um campo do saber ou área disciplinar, mas trata-se de uma área fronteiriça que recebe subsídios teóricos e metodológicos de diversos campos e "múltiplos atores" (p. 12). Ainda nas palavras dos autores:

As culturas juvenis se constituem em territórios usados na multiplicidade de processos societários produtores de espaços na contemporaneidade, sejam eles as praças ocupadas para as manifestações políticas e culturais, as mídias e as práticas de consumo ou a redes da internet que fazem fluir não apenas informações, mas também subjetividades coletivas. (Carrano \& Fávero, 2014, p. 13).

Nesse contexto em que se começa a apontar para novas interações nos estudos das juventudes, principalmente às ligadas às questões culturais e das relações com as mídias e o consumo, torna-se relevante estudar as interações 
de jovens com a produção audiovisual. Acredito que este movimento levará a mais informações acerca das representações juvenis, permitindo, dessa maneira, um reconhecimento dessas identidades e das possibilidades de ser jovem num mundo em que essas juventudes estão cercadas pelas diversas mídias, porém, nem todos têm acesso a elas, além disso, muitas dessas mídias apresentam um perfil de juventude estereotipado, ligado à violência, criminalidade e hedonismos.

Ao tratar das relações entre as mídias e as juventudes, Pacheco (2009, p. 33) afirma que "a juventude influencia e é influenciada nesta relação com os media, com o discurso político, social, acadêmico e das mais diversas ordens, criando-se representações de senso comum que são atribuídas à juventude."

A autora ainda aponta uma questão importante ao apresentar pesquisas realizadas pela Agência Nacional de Notícias dos Direitos das Crianças (ANDI). Segundo ela, a agência monitorou notícias que trazem personagens adolescentes e jovens e estas foram caracterizadas de três formas: centradas no mito da hiperdimensão, no da periculosidade e no mito da impunidade. No primeiro caso, centra-se nas notícias em que o adolescente é infrator e leva-se o leitor a pensar que o caso foi mais sério do que o fato registrado; no segundo mito, os casos de jovens e adolescentes registrados pela imprensa são aqueles mais graves, fazendo os leitores suporem que estes são sempre muito violentos e perigosos e, no terceiro mito, difunde-se a ideia de que jovens infratores sempre saem imunes e são ancorados pelo Estatuto da Criança e do Adolescente (ECA), que não os pune, quando na verdade, o estatuto, "prevê e disponibiliza medidas de correção quando se trata de questões relativas à chamada 'delinquência juvenil'." (Pacheco, 2009, p. 36).

É importante ressaltar que com base nos equívocos e excessos cometidos pelos meios de comunicação, muitas pessoas acreditam que jovens são violentos, não respeitam as entidades públicas e devem ser punidos drasticamente, principalmente relacionando essas representações aos jovens de classes populares. Nas palavras de Pacheco (2009, p. 34): “As imagens, o olhar que o público tem sobre crianças e jovens, certamente influenciam a sua forma de agir e pensar e a principal fonte de divulgação dessas imagens são os media."

Além dessas transformações sociais, é importante considerar também as transformações tecnológicas, que fazem com que todos, mas em maior destaque os jovens, lidem de maneira completamente nova com as mídias eletrônicas. A 
relação entre juventudes e essas mídias, em especial as que se estruturam em linguagem audiovisual, provavelmente reflete e configura formas de representação do que é ser jovem hoje.

Neste trabalho, parto da concepção de que, conforme os autores aqui apresentados, as juventudes são diversas e podem ser definidas a partir de inúmeros olhares, portanto, os jovens que foram pesquisados também apresentam suas peculiaridades: estudam numa escola pública, moram no bairro em que estudam e permanecem boa parte do dia na escola, que é o local de aprendizagens tanto formais quanto estético-culturais, nesta perspectiva, ao apresentá-los e também as atividades desenvolvidas na pesquisa, estas características aparecerão no decorrer do percurso metodológico e analítico.

Durante o desenvolvimento da pesquisa, o espaço escolar foi fundamental para entender estes jovens, além disso, foi neste espaço que pude entender as relações que eles estabelecem com o audiovisual e com as mídias de maneira geral, uma das principais evidências foi, por exemplo, entender que apesar de conhecerem vários suportes midiático-tecnológicos, muitos não têm acesso a eles por questões socioeconômicas desfavoráveis, o que os coloca, muitas vezes, à margem das inovações tecnológicas a que outros jovens convivem mais diretamente.

Nos próximos capítulos, tratarei especificamente dos jovens sujeitos da pesquisa, seus gostos, seus hábitos culturais e o espaço escolar em que atuam por ser o espaço que passam mais tempo do seu dia. Além disso, apresentarei os suportes teórico-metodológicos e práticos usados no desenvolvimento da pesquisa de campo. 


\title{
4 \\ Metodologia da pesquisa
}

\author{
Uma pesquisa é sempre, de alguma forma, um relato de longa \\ viagem empreendida por um sujeito cujo olhar vasculha lugares \\ muitas vezes visitados. Nada de absolutamente original, \\ portanto, mas um modo diferente de olhar e pensar \\ determinada realidade a partir de uma experiência e de uma \\ apropriação do conhecimento que são, aí sim, bastante \\ pessoais. (Duarte, 2002, p. 140).
}

A pesquisa empreendida para elaboração deste trabalho ocorreu durante todo o ano letivo de 2016. Desenvolvida como pesquisa-intervenção, envolveu a realização de oficinas de visualização ${ }^{14}$ de filmes, diário de campo, questionários, áudio e videogravações e registros impressos de atividades desenvolvidas pelos sujeitos ${ }^{15}$ da pesquisa.

Neste capítulo, apresento os procedimentos metodológicos adotados na produção e na análise do material empírico. Assim, partindo da perspectiva da epígrafe apresentada, o esforço de escrita deste é para dar ao leitor do texto a dimensão do que foi desenvolver esta pesquisa. Dessa forma, seguindo o proposto por Duarte (2002, p. 140), entendo que: "relatar procedimentos de pesquisa, mais do que cumprir uma formalidade, oferece a outros a possibilidade de refazer o caminho e, desse modo, avaliar com mais segurança as afirmações que fazemos."

\section{1}

\section{Como e por que desenvolver pesquisa qualitativa?}

Conforme já anunciado, meu interesse nesta pesquisa é compreender como as narrativas audiovisuais participam da representação das juventudes, na perspectiva de jovens de classes populares. Optei por essa classe social por entender que eles configuram um segmento importante da população que assiste a filmes, sendo estes, muitas vezes, um dos poucos acessos que este

\footnotetext{
${ }^{14}$ Optei pelo termo "visualização" de filmes, por entender que as oficinas foram momento de exibição mediada dos filmes, cujo objetivo não era apenas ver os filmes, mas refletir e discutir sobre a construção narrativa e estética deles, para isso, todas as exibições foram previamente preparadas e o material empírico produzido por mim para o momento do debate. Neste sentido, entendo que os termos exibição e fruição não seriam apropriados para esta proposta.

${ }^{15}$ Neste trabalho, as expressões "sujeitos de pesquisa", "atores envolvidos", "pesquisados", "sujeitos pesquisados", "alunos participantes da pesquisa", "jovens" e "alunos" serão usadas como sinônimos para que o texto não fique repetitivo.
} 
público tem à produção cultural. Para os jovens de camadas populares, as mídias estão entre as principais fontes de entretenimento e de informação.

Tendo como perspectiva este objetivo, minha pesquisa é de cunho qualitativo. Ao definir a pesquisa qualitativa, Ludke e André (1986), apoiadas em Bogdan e Biklen (1982), apresentam cinco características básicas deste tipo de pesquisa, entre as quais se destaca a importância dos dados descritivos, tanto relacionados ao espaço da pesquisa, quanto aos sujeitos e às situações envolvendo o processo de pesquisa e o cotidiano dos sujeitos pesquisados. As autoras apontam como uma característica básica desse tipo de pesquisa a importância de o processo ser, muitas vezes, mais relevante do que o produto ou resultado final, por isso numa pesquisa de cunho qualitativo apontar os caminhos metodológicos é tão importante quanto mostrar o resultado.

Sendo assim, torna-se importante apresentar todos os passos da pesquisa de campo e caracterizá-la a partir dos caminhos percorridos para a obtenção do produto final, que como as autoras destacam, é sempre indutivo, ou seja, parte das evidências encontradas, mas também das abstrações do pesquisador e tomará diferentes rumos dependo do grau de envolvimento deste. Traçar os caminhos da pesquisa antes que ela acontecesse foi essencial, mesmo com as várias mudanças de cronogramas sofridas em função de paralisações de professores ou falta de material para o desenvolvimento das oficinas previstas.

Esta pesquisa pode ser caracterizada como sendo uma pesquisaintervenção ou pesquisa-ação, visto que a metodologia de produção de dados empíricos envolve ações de intervenção direta no lócus onde se realizou e no cotidiano dos sujeitos de pesquisa. Não se trata de realizar observações e/ou registros acerca de situações ou circunstâncias regulares do local onde se deu o estudo, mas de agir e intervir nesse contexto, propondo atividades e registrando o desenvolvimento destas e as reações daqueles de que delas participaram. Trata-se, portanto, de construir uma parceria direta com os sujeitos de pesquisa, em contexto de investigação. Segundo Dionne (2007, p. 69): “A associação entre pesquisadores e atores está no centro do processo de pesquisa-ação, mas ela só terá valor se tiver efeitos de mudança e se puder alimentar a própria ação e o engajamento dos participantes na ação". De acordo com Dionne (2007, p. 77):

A pesquisa-ação é antes de tudo um modo de intervenção coletiva que se insere em um processo de mudança social. É realizada junto a grupos reais e é centrada em uma situação concreta, que constitui um problema. Sua duração é a de um projeto de intervenção. Persegue dois objetivos concomitantes: modificar uma dada situação e adquirir novos conhecimentos. Pressupõem-se vínculos estreitos entre pesquisadores e atores. Fortalece o relacionamento entre teoria e prática. 
Permite gerar conhecimentos novos e originais. Tem um alcance sociopolítico maior.

As atividades de pesquisa foram realizadas no contraturno das turmas do ensino fundamental de uma escola e, sendo realizadas desta forma, como proposta de um projeto extracurricular, mas ligado à formação dos alunos da escola em questão, criou-se, conforme Dionne (2007), um vínculo de cooperação entre atores e pesquisadores, o que contribui para uma aproximação maior entre pesquisadores e pesquisados. Nas palavras do autor:

A elaboração e a partilha dos conhecimentos ocorrem em relações de convivência que incitam, ao mesmo tempo, o pesquisador a coletar os conhecimentos derivados da ação e 0 ator a contribuir diretamente para a produção de conhecimentos. A divisão social do trabalho profissional entre pesquisador e o participante-ator tende a desvanecer-se, tornando-se um coletivo engajado em uma mesma intervenção. (Dionne, 2007, p. 34).

Para o desenvolvimento da pesquisa foram propostas oficinas de visualização de filmes com os alunos do ensino fundamental II da escola pesquisada. Entendo o trabalho com oficinas, assim como Andrade e Lucinda (2011), como um espaço de desenvolvimento prático de temas do cotidiano. Partindo do conceito clássico de oficina como local de consertos ou, ainda, "de aprendizagem de certo grau de habilidades, desenvolturas ou competências ao campo das artes" (p. 258), a oficina pode ser um espaço em que se "aprende trabalhando". Para esses autores, há duas características essenciais para uma oficina: "(1) trabalho coletivo e (2) processos de ensino-aprendizagem que integra teoria e prática" (p. 259). No desenrolar desta pesquisa, essas duas características ficaram evidenciadas no desenvolvimento das oficinas de visualização de filmes. Isso comprovou a relação direta das oficinas com a pesquisa-ação ou pesquisa-intervenção, visto que, tendo realizado as atividades propostas, os participantes não saíram da mesma forma que entraram, ou seja, mesmo que não possam ser mensuradas, as oficinas desenvolvidas durante a pesquisa, modificaram o modo de ver filmes dos atores envolvidos.

Nessas oficinas, usei os materiais da escola, como computador, TV, DVD, projetor multimídia e caixas de som, que foram instalados na sala destinada às atividades da pesquisa. Os filmes selecionados foram comprados por mim em DVD para que pudessem ser exibidos para os alunos; além disso, foi também de minha responsabilidade preparar os materiais utilizados nas rodas de conversa, momento posterior à visualização dos filmes.

É importante ressaltar que oficinas como recurso de pesquisa são muito comuns, quando se quer analisar fenômenos grupais, principalmente quando os 
interesses da pesquisa estão ligados a aspectos subjetivos e sociais. Nesses casos, grupos focais ou perguntas direcionadas, como uma entrevista, por exemplo, podem fazer com que os sujeitos ajam e/ou falem de maneira superficial, ou sintam-se pouco à vontade para expressar o que pensam de maneira clara e direta.

Segundo Lima e Abade (2009), as oficinas pressupõem um estabelecimento de relações, posto que envolvem os sujeitos de maneira integral, levando-se em conta suas formas de agir, sentir e pensar. Dessa forma, há sempre elementos disparadores que levarão ao debate ou a outras atividades que proporcionarão aos sujeitos a possibilidade de manifestarem-se sobre o tema proposto sem se sentirem pressionados ou intimidados pelo pesquisador.

Um fator relevante envolvendo o método de oficinas é que, à medida que os encontros vão acontecendo, é possível trazer novas estratégias e dinâmicas para envolver mais o grupo e essas dinâmicas são os elementos disparadores das atividades propostas. Afonso (2000) aponta que o planejamento deve ser flexível, visto que implica a contínua transformação, enquanto fluir o processo grupal. Lima e Abade (2009) afirmam que a definição da sequência de temas e técnicas é feita ao longo do processo da oficina, o que torna possível perceber a demanda dos sujeitos. No caso desta pesquisa com jovens, a expectativa inicial era deixá-los à vontade para manifestarem-se a respeito das representações das juventudes no audiovisual e, ao longo das semanas, percebi que o clima para o debate foi ficando mais favorável; do primeiro ao último encontro a relação entre mim e eles ficou mais próxima, o que facilitou o diálogo entre os envolvidos.

Para o desenvolvimento das oficinas, foi essencial fazer um planejamento que frequentemente começava com o levantamento de dados sobre o filme a ser exibido (produção, custos, seleção dos atores, notícias veiculadas, campanha publicitária, críticas e comentários veiculados, entre outros). Depois disso, os filmes selecionados eram assistidos e eram feitas anotações sobre cenas ou questões importantes que ajudariam na elaboração dos elementos disparadores das atividades a serem realizadas nas rodas de conversa. Esses elementos disparadores podiam ser desde uma cena do filme exibido, que merecia ser discutida, ou escolhas estéticas na composição de algum personagem (aspectos físicos, figurino, ângulos, fotografia, trilha musical, etc.) e da narrativa (cenários, planos, estrutura, roteiro, organização, fotografia, trilha musical, etc.) ou um texto ou reportagem que analisasse o filme ou a proposta de escrita a partir da ação de um personagem, entre outras atividades que foram sendo criadas ao longo do processo. 
Segundo Afonso (2000), citando Lewin (1988) e Mailhiot (1991), as oficinas em grupo permitem a interação face a face, em que os indivíduos participam de um processo de comunicação "intersubjetivo, com linguagem verbal e nãoverbal" (p. 13).

Inicialmente, a partir desse entendimento de que as ações dos sujeitos seriam tão importantes quanto a fala, visto que existe uma linguagem não verbal fazendo parte dos acontecimentos, optei por registrar as oficinas em vídeo. Porém, levantei a possibilidade de a videogravação alterar as ações dos sujeitos, pois alguns poderiam ficar mais retraídos e outros mais dispostos a falar para a câmera, e não necessariamente para mim e os colegas. Sendo assim, após essa avaliação, optei pela gravação das oficinas em áudio, pois além de ser mais fácil, sendo necessário apenas um gravador potente, era mais cômodo para transportar para o campo de pesquisa; o gravador é uma ferramenta que chama menos atenção e tende a distrair menos os sujeitos pesquisados, não comprometendo a dinâmica das oficinas.

Porém, eu tinha o entendimento de que é importante não apenas registrar a fala dos sujeitos de pesquisa, mas suas expressões faciais, corporais, as reações diante do filme, das falas dos colegas e outros, portanto, a captação da imagem em movimento seria importante neste tipo de pesquisa, pois talvez apenas as anotações feitas por mim e as audiogravações não capturassem a dinâmica do ambiente. Dessa forma, em alguns momentos, foram feitas videogravações, usando o celular e uma máquina fotográfica caseira e estes recursos também foram usados em algumas atividades da roda de conversa, momento das oficinas em que eu abria para o debate do filme visto.

Segundo Garcez, Duarte e Eisenberg (2011, p. 253), no caso de pesquisas com crianças em grupos, "é importante lembrar que elas falam ao mesmo tempo, interagem, brincam, sentam, levantam, não param quietas e comunicam-se entre si e com os pesquisadores durante todo o tempo." Penso que o mesmo ocorre com grupos de jovens, principalmente, neste caso, em que os jovens já têm uma convivência anterior, ou seja, não se reuniram apenas em função da pesquisa de campo. A videogravação foi um registro importante para o momento das atividades em grupo, em que alguns sujeitos faziam intervenções interessantes para o desenvolvimento da pesquisa e que poderiam passar despercebidos, permitindo revisitar o campo a partir da gravação. O mesmo ocorreu com as audiogravações: a partir do momento em que os sujeitos já se tornaram conhecidos, era possível identificar suas vozes e as reações nos registros de áudio. 
Garcez, Duarte e Eisenberg (2011) enfatizam também que ver os vídeos gravados, ainda durante o desenvolvimento da pesquisa, pode contribuir para melhorar a performance do pesquisador durante o período em que a pesquisa está acontecendo, o que permite ajustes que podem ser feitos em suas próximas idas ao campo. Penso que o mesmo ocorre com as gravações em áudio. Depois dos encontros com os alunos, eu ouvia as gravações, via as fotos tiradas durante as oficinas, entendendo que estas atividades serviam como um exercício de reflexão e de retomada de alguns aspectos que poderiam ter se perdido no momento do encontro. Além disso, durante as atividades, é importante ter em mãos um caderno para anotar as impressões do campo. Nas primeiras atividades, as anotações serviram de suporte para pensar os desdobramentos da pesquisa e fazer, inclusive, algumas modificações dos procedimentos preestabelecidos.

Ao final do trabalho de campo, as audiogravações, videogravações, fotos, atividades desenvolvidas pelos jovens pesquisados e as notas de campo foram submetidas à análise de conteúdo (AC).

Garcez, Duarte e Eisenberg (2011) alertam que é necessário, após as videogravações, catalogar o material gravado para posterior análise, o mesmo ocorre com os áudios. Assim, todo o material foi catalogado e organizado em pastas virtuais, por encontro, o que facilitou a busca e identificação de conteúdo, em especial de falas que haviam chamado a minha atenção e tinham sido, por essa razão, registradas no caderno de campo, sendo mais fácil, voltar à gravação daquele momento e reconstituir a cena.

As autoras alertam que a transcrição do material pode provocar perda de qualidade, visto que a linguagem escrita pode não ser capaz de registrar as ações captadas nas imagens. Elas recomendam o uso da $A C$ de vídeo. A AC permite a análise sintática e semântica, ou seja, vai da palavra e suas dimensões gramaticais e formais para os possíveis sentidos em que elas são empregadas. Esta técnica foi adotada na análise dos dados desta pesquisa, pois se mostrou coerente com o tipo de material produzido nas oficinas.

Segundo Bauer (2013, p. 195):

A AC trabalha tradicionalmente com materiais textuais escritos, mas procedimentos semelhantes podem ser aplicados a imagens [...] ou sons [...]. Há dois tipos de textos: textos que são construídos no processo de pesquisa, tais como transcrição de entrevista e protocolo de observação; e textos que já foram produzidos para outras finalidades quaisquer, como jornais ou memorandos de corporações. Os materiais clássicos da $A C$ são textos escritos que já foram usados para algum outro propósito. Todos esses textos, contudo, podem ser manipulados para fornecer respostas às perguntas do pesquisador. 
No caso da pesquisa em tela, a AC serviu como suporte para análise do material coletado em campo (áudios, vídeos, fotos e materiais produzidos pelos sujeitos de pesquisa). Para proceder à análise deste material, foi utilizada a versão 8.0 do programa ATLAS Ti, que é uma ferramenta que permite trabalhar com diversos formatos de mídia e extensão de arquivos. Além disso, no caso da vídeo e da audiogravação, o programa permite a codificação direta do material, tornando a análise possível sem a necessidade da transcrição das falas e situações. No que se refere ao material produzido na pesquisa de campo, ao escutar os áudios, por exemplo, era possível marcar os trechos mais significativos, sendo esses trechos transcritos por mim. A utilização do programa e os procedimentos de análise serão mais bem detalhados na apresentação dos resultados.

\section{2}

\section{Preparação do trabalho de campo}

Desde o início dos estudos para esta pesquisa, era de meu interesse desenvolvê-la numa escola pública da cidade de Juiz de Fora, visto ser a cidade onde moro e na qual atuava como professora de Língua Portuguesa, nas séries finais do ensino fundamental e no ensino médio.

Durante o processo de escrita do projeto, procurei alguns professores e escolas em que a pesquisa pudesse ser desenvolvida, ainda fazendo um levantamento inicial das possibilidades de abertura dessas escolas e dos docentes que nelas atuam. Como a pesquisa consistia em oficinas de visualização de filmes e o ideal seria realizar encontros semanais, havia a dificuldade de uso dos horários das disciplinas curriculares para tal atividade, visto que os tempos de aula são de $50 \mathrm{~min}$ e grande parte dos filmes selecionados para exibição tinha mais de uma hora e meia de duração, o que comprometia a dinâmica do tempo escolar.

Após conversas com professores da rede municipal de educação de Juiz de Fora, encontrei uma escola que desenvolve projetos interdisciplinares no contraturno e uma professora ofereceu seu projeto para o desenvolvimento da pesquisa.

Os filmes selecionados para exibição obedeciam a um critério bem específico: foram filmes que tinham jovens como protagonistas e que integraram a lista de filmes de maiores bilheterias dos cinemas brasileiros no ano de 2014 . 
É importante mencionar que, ao final de cada ano, a Ancine faz este levantamento e divulga no início do ano seguinte a lista dos 20 filmes com maiores bilheterias do ano anterior. $E$ foi a partir desse levantamento da Ancine (2015), que cheguei a oito filmes:

1) A culpa é das estrelas - dirigido por Josh Boone, inspirado no romance de John Green, lançado no Brasil em 5 de junho de 2014, filme classificado como drama, com 125 minutos de duração e não recomendado para menores de 12 anos;

2) Malévola - dirigido por Robert Stromberg, lançado no Brasil em 29 de maio de 2014, filme com 96 minutos e não recomendado para menores de 10 anos;

3) X-Men: dias de um futuro esquecido - dirigido por Bryan Singer, lançado no Brasil em 22 de maio de 2014, um filme de ação, com 131 minutos de duração e não recomendado para menores de 12 anos;

4) Jogos vorazes: a esperança - parte 1 - dirigido por Francis Lawrence, lançado no Brasil em 19 de novembro de 2014, com 193 minutos e não recomendado para menores de 14 anos;

5) Capitão América 2: o soldado invernal - dirigido por Anthony Russo, lançado no Brasil em 10 de abril de 2014;

6) O espetacular Homem-Aranha 2 - dirigido por Mark Webb, lançado no Brasil em $1^{\circ}$ de maio de 2014;

7) O Hobbit: a batalha dos cinco exércitos - dirigido por Peter Jackson, baseado na obra de J. R. Tolkien, lançado no Brasil em 11 de dezembro de 2014;

8) Guardiões da galáxia - dirigido por James Gunn, lançado no Brasil em 31 de julho de 2014.

A escolha pelo ano de 2014 se deu em função de estes filmes já terem sido lançados em DVD; dessa forma, os filmes foram adquiridos na versão original para não comprometer a qualidade da exibição.

Desde o início da escolha dos filmes, deixei em aberto se todos aqueles selecionados seriam exibidos, visto que contaria com a receptividade da proposta pelos participantes da pesquisa e os percursos do campo poderiam apontar outros caminhos. De qualquer forma, optei por exibi-los pela ordem do ranking divulgado pela Ancine. Durante o desenvolvimento da pesquisa, houve algumas mudanças e desta seleção inicial, apenas os quatro primeiro filmes foram exibidos, por isso são descritos mais detalhadamente. 
Enquanto aguardava as aprovações dos Conselhos de Ética da PUC e da Secretaria de Educação Municipal de Educação de Juiz de Fora, fui adquirindo os filmes, assistindo-os e preparando atividades que motivassem a discussão. A ideia era, após a exibição dos filmes, promover um debate com os participantes da pesquisa que girasse em torno dos elementos narrativos apresentados e das representações de juventudes. Nesse sentido, a cada filme, além do debate, pensei na criação de um material concreto que retratasse o que eles pensavam: um desenho, uma frase, uma questão que fosse respondida e devolvida para posterior análise, esses materiais foram considerados como elementos disparadores das oficinas e compuseram o corpus empírico de análise desta tese.

Ao começar a assistir aos filmes, percebi que eu teria dificuldades em exibi-los e discuti-los em um só encontro. Conforme destacado anteriormente, os tempos escolares acabam desfavorecendo determinadas atividades. Nesse período, já havia encontrado a escola que satisfazia aos pressupostos da pesquisa, porém, eu só teria $1 \mathrm{~h} 20 \mathrm{~min}$ (o que equivale a $80 \mathrm{~min}$ ) por semana com cada turma. O tempo de oficina era insuficiente para exibição e discussão dos filmes.

A única solução para esse problema seria dividir os filmes em duas partes, exibindo a parte maior no primeiro dia e deixando a segunda parte e o debate para a semana seguinte, porém, em uma semana, muitas informações poderiam se perder.

Para avaliar a adequação dos procedimentos planejados foi realizada uma oficina piloto em outra escola da rede, que tinha um perfil próximo ao da escola selecionada para a pesquisa, dividindo o tempo de exibição do filme, conforme seria feito no trabalho de campo definitivo.

\subsection{1}

\section{Oficina piloto}

No início de março de 2016, procurei alguns colegas e um professor de educação física sugeriu que eu desenvolvesse o piloto da primeira oficina na escola municipal onde ele trabalhava, com seus alunos do $9^{\circ}$ ano. Da mesma forma que a escola pesquisada, esta é de porte pequeno, com alunos de classes populares. Sendo também uma escola da rede municipal de Juiz de Fora e com uma infraestrutura parecida a da escola em que a pesquisa seria realizada. 
O projeto piloto foi realizado nos dias 16 e 23 de março de 2016. Para esse primeiro contato, havia planejado uma rápida apresentação da dinâmica e a visualização de uma hora do filme $A$ culpa é das estrelas, planejado para a pesquisa de campo. Com a demora na montagem do equipamento, após a apresentação da dinâmica, iniciamos a exibição do filme e passamos apenas os primeiros $50 \mathrm{~min}$, faltando, portanto, $10 \mathrm{~min}$. Paramos o filme em um momento que ocorre uma mudança no cenário onde vivem as personagens, procurando assegurar uma boa expectativa para continuidade na semana seguinte.

A turma em que o filme foi exibido tinha 22 alunos, com idades entre $13 \mathrm{e}$ 15 anos. Ao chegar, conversei rapidamente com eles, montamos o projetor, alguns alunos ajudaram a colocar um pano branco em cima do quadro negro (na verdade, no segundo dia, percebi que não era um pano branco e sim um pôster de algum evento colocado ao contrário - do lado branco) e pedi que ficassem sentados mais à vontade, em lugares que facilitassem a visualização do filme. Os alunos fecharam as cortinas, o que deixou o ambiente mais propício para a visualização do filme.

Uma das alunas perguntou qual filme veríamos, eu mostrei a capa do filme, pedi que passassem entre eles e alguns leram a sinopse; muitos se mostraram interessados, perguntei se alguém já tinha visto e apenas uma aluna respondeu afirmativamente. Avisei a eles que veríamos apenas metade do filme e que a outra metade só seria exibida na semana seguinte e eles não demonstraram ficar contrariados com isso. Disse que, ao final da exibição da primeira parte, eu gostaria que dois deles se candidatassem a fazer a sinopse do que foi visto para relembrar aos colegas na semana seguinte. Eles pediram que o filme fosse exibido com legenda, mas dublado em português, pois não conseguiam acompanhar a legenda. O pedido foi acatado e essa estratégia também foi utilizada na pesquisa de campo, pois há uma preferência entre eles pelos filmes dublados. Vários jovens relataram a dificuldade em acompanhar imagem e leitura da legenda.

Durante a exibição do filme, os jovens ficaram muito atentos, alguns comentavam cenas com os colegas mais próximos. Quando faltavam dois minutos para o término da aula, interrompi o filme, que já estava nos 50 minutos. Um aluno e uma aluna se candidataram para fazer a sinopse do que foi visto, o que seria feito na semana seguinte, antes da exibição da segunda parte do filme. Apesar de não ter conseguido exibir o filme até onde eu pretendia, o resultado havia sido positivo, pois houve uma boa recepção e eles pareceram não ter se chateado com o fato de não verem o filme todo. Outra coisa importante: eles 
assistiram ao filme antes do intervalo para o recreio, dessa forma, caso ocorresse algum imprevisto, eu poderia contar com alguns minutos do intervalo para encerrar alguma atividade e isso foi preciso ser feito na semana seguinte, conforme será relatado.

Em função de ter de montar o equipamento, combinei com a professora de língua portuguesa, que daria a aula anterior, e com o professor de educação física que chegaria mais cedo à escola e usaria os $50 \mathrm{~min}$ da aula de língua portuguesa, e não apenas os $20 \mathrm{~min}$, como na primeira oficina, assim teria de $8 \mathrm{~h} 05$ até as $9 \mathrm{~h} 45$ (o que equivalia a $1 \mathrm{~h} 40$, sendo repostos os 10 minutos perdidos na primeira oficina) para montar o equipamento de exibição do filme, pedir aos sinopsistas para fazer o feedback do filme até o momento, exibir o restante do filme e propor a atividade preparada, além de desmontar o equipamento e fazer um desfecho da atividade com a turma. É preciso lembrar que na escola selecionada para a pesquisa, o equipamento já fica montado na biblioteca, onde foram realizadas as oficinas, o que diminui o tempo com as atividades que antecedem a exibição, porém, no cotidiano da pesquisa, nem sempre pude usar o espaço da biblioteca, o que gerou algumas dificuldades que serão relatadas mais adiante.

Essas dificuldades na projeção dos filmes são parecidas com as encontradas por Medeiros (2016), ao tratar dos recursos materiais e da disposição do espaço físico para a projeção dos filmes que faziam parte de sua pesquisa de campo, a qual consistia na visualização de filmes com alunos do curso de pedagogia da Faculdade de Educação da UFJF. Segundo o autor:

É importante reiterar o significativo fato de a Faculdade de Educação, como grande parte das escolas, não possuir instalações adequadas para a fruição fílmica. Improvisamos uma sala com equipamento de DVD e data show, além de um precário aparelho de uso doméstico de amplificação de som. Em quase todas as sessões, os equipamentos deram problemas, ocasionando interrupções que não favoreciam o mergulho dos espectadores no tempo-espaço fílmicos. (Medeiros, 2016, p. 141).

Essa temática do tempo-espaço escolar para a visualização de filmes remete à discussão feita por Merlo (2014), ao tratar da experiência com o Programa de Alfabetização Audiovisual, desenvolvido em escolas públicas do Rio Grande do Sul:

Se pensarmos no contexto da escolarização formal, pouco pode ser feito nos estreitos tempos/espaços já demarcados na escola. O tempo escolar, fracionado em dias letivos, períodos, avaliações, pareceres e seus programas, convida à fragmentação e à aceleração dos processos. Mais do que acelerar, abrevia o necessário tempo de repouso e de retomada das aprendizagens, reduzindo a sua maturação e consolidação pelos alunos. (p. 294- 295). 
Merlo (2014) avalia que na educação integral há uma flexibilidade maior com os tempos/espaços e isso favorece a alfabetização audiovisual. No desenrolar desta pesquisa, identifiquei que mesmo a educação integral tem amarras e formatos que, em alguns momentos, servem como grades e a flexibilidade fica bastante controlada.

$\mathrm{Na}$ semana seguinte, cheguei à escola bem mais cedo, junto com os alunos e aguardei o término da primeira aula, de língua portuguesa (de 7h15 às 8h05) na sala dos professores. Em seguida, a professora dessa disciplina me convidou para entrar na sala e recomeçar a atividade da semana anterior.

Como na primeira semana, os alunos foram até a diretoria, pegaram o projetor e o pôster para colar no quadro e eles próprios prepararam o ambiente para a visualização da segunda parte do filme. A professora pediu licença para ficar na sala e permaneceu acompanhando a exibição do filme até as 8h05, quando foi dar aula em outra turma. Nesse momento, entrou o professor de educação física, que permaneceu conosco até o fim das atividades. Dezoito alunos estavam presentes na segunda parte da oficina.

Antes de começar a exibição do filme, pedi que lembrassem as cenas do filme que já havíamos visto, dois alunos tinham sido selecionados para isso, porém eles ficaram envergonhados e, para não atrasar a exibição do filme, eu tomei a atitude de ir perguntando a eles algumas particularidades do enredo, o que eles responderam prontamente. Essa parte da oficina foi gravada em áudio, por meio do qual é possível perceber que muitos deles conversavam antes do início da exibição do filme, porém quando o filme começou, eles se calaram rapidamente, inclusive com uns pedindo aos outros para que permanecessem em silêncio.

Nesse dia, diferentemente do anterior, percebi que a turma estava mais agitada; além disso, fora da sala de aula havia uma maior movimentação, pois os funcionários da escola estavam fazendo faxina no pátio próximo à sala, o barulho e as vozes vindas de fora atrapalharam um pouco; como era véspera de feriado, achei a turma mais dispersa em alguns momentos do filme. Porém, como aconteceu no primeiro dia, em vários momentos eles comentaram algumas cenas entre eles, mostrando-se interessados.

Quando faltavam 20min para o filme terminar e começarmos a discussão, a luz de toda a escola acabou. O professor informou que isso não era comum, mas quando acontecia, podia demorar a voltar. Para não perder tempo, resolvi antecipar a roda de conversa e pedi a eles para preencherem a ficha que preparei para aquela ocasião com questões sobre o filme, e depois começamos 
a discussão em torno das respostas deles. A atividade estava prevista para $20 \mathrm{~min}$, mas como a luz não havia voltado, durou 35min, até que a luz voltasse. Quando a luz voltou, continuamos a exibição do filme, o sinal para o intervalo bateu e falei com os alunos que eles não eram obrigados a permanecer na sala. Alguns preferiram ficar, outros foram buscar a merenda e voltaram. O filme terminou junto com o intervalo e, no final, quase todos os alunos estavam em sala e bateram palmas, assim como no primeiro dia.

Além do preenchimento das fichas sobre as personagens, pedi aos alunos que respondessem se gostaram ou não do filme e justificassem, tendo gravado as respostas em áudio. Saí de lá com a sensação de que por mais que nos programemos, a pesquisa de campo é sempre uma surpresa e por mais que estejamos preparados, sempre acontecem imprevistos.

Porém, minha maior preocupação - a de ser um grande problema para a pesquisa dividir os filmes em partes - foi amenizada, pois percebi que os alunos de uma semana para outra não esqueceram detalhes do filme e que a discussão da segunda semana foi bastante produtiva.

\subsection{2 \\ Alguns ajustes após o projeto piloto}

Inicialmente eu havia pensado em fazer audiogravações apenas dos momentos de debate e apresentação dos filmes, porém, percebi que durante a exibição dos filmes, há alguns comentários dos jovens que podem contribuir com a análise e, a partir disso, resolvi gravar todo o tempo em que eu estivesse com os sujeitos de pesquisa: das conversas que antecedem aos filmes até os comentários após a visualização, passando pelo momento de exibição dos filmes. O referencial teórico que trata da metodologia da análise de conteúdo, de videogravações e audiogravações na pesquisa de campo em ciências sociais foi essencial para a tomada dessa decisão.

Outra ideia inicial era aproveitar o espaço antes da exibição dos filmes para apresentar algum elemento do cinema, ou algum conceito, porém, vi que poderia ficar "didatizante", o que não é objetivo desta pesquisa; além disso, o tempo era bastante limitado e o ideal, portanto, era priorizar a exibição dos filmes e o debate em torno da representação das juventudes no cinema.

Outra questão importante: da mesma forma que alguns alunos faltaram à aula no segundo dia de exibição, enfrentei essa mesma questão durante a 
pesquisa de campo, porém, percebi que isso não atrapalhou grandemente o desenvolvimento das oficinas, desde que a retomada do que aconteceu antes fosse feita obrigatoriamente. Dessa forma, o momento de resumo do que vimos na sessão anterior foi importante não só para lembrar quem estava acompanhando o filme, mas também para dar uma noção parcial para aqueles que perderam a primeira parte e, mesmo assim, assistiram à segunda. $A$ vivência dessa situação na oficina piloto deu ciência de que essa era uma situação que poderia ocorrer no trabalho de campo e era preciso saber conduzir esta questão para não atrapalhar a pesquisa e nem os demais sujeitos envolvidos.

Assim como tive de me reorganizar quando a luz acabou no trecho final do filme, no desenrolar da pesquisa outras situações inesperadas ocorreram. Nesse sentido, é importante que o pesquisador esteja ciente de que podem ocorrer situações que fogem completamente ao nosso controle. Dessa forma, penso que o projeto piloto foi de extrema importância para ajustar questões de procedimento (como o áudio, por exemplo) como também para dar mais segurança na entrada definitiva ao campo de pesquisa.

Nas atividades desenvolvidas na escola selecionada para a pesquisa, segui, na maioria das vezes, os mesmos procedimentos de ação adotados no projeto piloto: conversa inicial, exibição e atividade prática envolvendo as questões do filme. Todos os encontros foram registrados em diário de campo e será apresentado um quadro-resumo dessas atividades no capítulo seguinte.

No próximo capítulo, os sujeitos da pesquisa e o campo empírico, além das categorias de análise serão evidenciados. 


\title{
5 \\ Campo empírico
}

\begin{abstract}
São muitos os jovens aprisionados no espaço e no tempo presos em seus bairros periféricos e com enormes dificuldades para articularem projetos de vida. Sujeitos que, por diferentes razões têm pouca experiência de circulação pela cidade e se beneficiam pouco ou quase nada das atividades e das redes culturais públicas ofertadas em espaços centrais e mercantilizados de nossas cidades. (Dayrell \& Carrano, 2014, p. 127).
\end{abstract}

Neste capítulo, tratarei das motivações para a pesquisa na escola selecionada, o cenário da pesquisa, os atores envolvidos, além de uma síntese da pesquisa de campo.

\section{1}

\section{A escola pesquisada}

A opção pelo campo de pesquisa se deu em função de ser uma escola de tempo integral que mantém regularmente oficinas diversas no contraturno, chamadas de "projetos", e são desenvolvidas durante um semestre letivo. Além dessa característica da escola, em conversa informal com a professora do Projeto Contadores de Histórias, ela se mostrou interessada em uma parceria para o ano letivo de 2016. Vale destacar, ainda, que o perfil dos alunos da escola preenchia ao desejado para a pesquisa: jovens de classe popular, moradores de bairros periféricos. O questionário respondido por esses jovens (apresentado na seção seguinte) corrobora essas impressões iniciais. Além disso, o questionário respondido por eles na Prova Brasil/2015 confirma o perfil mencionado.

Segundo o projeto político pedagógico (PPP) da escola:

A Escola Municipal $\mathrm{X}^{16}$ foi fundada em 1969 no bairro A para atender a uma população proveniente de áreas rurais. Durante muitos anos o nível de ensino priorizado atendia até a $4^{\text {a }}$ série do ensino fundamental, sendo o tempo organizado em séries. A partir do ano 2000 as discussões sobre a organização do tempo escolar em ciclos de formação transformaram o perfil da escola, resultando num processo de transformação pedagógica. A escola apresenta uma organização curricular que tem como eixos os Estudos Antropológicos, fomentando a reflexão sobre os processos de construção de identidades, as relações étnico-raciais no cotidiano escolar e a diversidade. (PPP da Escola, 2013, $\mathrm{s} / \mathrm{p}$.).

\footnotetext{
${ }^{16}$ Chamarei a escola pesquisa de $\mathrm{X}$ e o bairro onde ela foi fundada de $\mathrm{A}$.
} 
Além das mudanças na estrutura curricular, os anos 2000 foram de mudanças intensas na escola, pois, segundo o PPP (2013), em 2002, a escola passou a atender a todos os anos do ensino fundamental e da educação infantil. Com espaço físico limitado, no segundo semestre de 2008, a unidade ganhou nova sede, mudando-se do bairro A para outro bairro a dois quilômetros de distância da sede anterior.

Com a nova sede inaugurada, a Secretaria de Educação de Juiz de Fora propõe que a escola seja uma das cinco primeiras escolas da rede a tornar-se uma unidade de tempo integral, visto que, desde 2002, ela desenvolvia projetos com oficinas no contraturno das atividades escolares. Esses projetos eram opcionais e participavam deles os alunos cujos pais autorizavam a permanência na escola após as atividades curriculares.

Com a mudança de sede e a perspectiva de uma política de tempo integral sendo engendrada pela prefeitura de Juiz de Fora, a escola assumiu o desafio de manter os alunos durante oito horas sob sua tutela. Atualmente, houve uma diminuição no horário e a escola funciona de $7 \mathrm{~h} 30$ as $15 \mathrm{~h} 30$. No caso dos anos finais do ensino fundamental (6ำ ao $9^{\circ}$ ano), a partir de 2010 , os alunos passaram a ter, pela manhã, as disciplinas curriculares e à tarde participam das oficinas.

A escola tem aproximadamente 300 alunos, sendo uma turma para cada nível de ensino. Há em torno de 100 alunos do 6oa ao anos. É importante destacar que, desde a implementação do tempo integral, várias mudanças foram ocorrendo, tanto para atender às necessidades dos alunos, quanto do restante da comunidade, inclusive questões ligadas à infraestrutura, pois há poucas salas disponíveis e materiais como TV, projetor e DVD, por exemplo, são escassos.

O espaço físico da escola compreende 11 salas de aula, quatro banheiros (dois masculinos e dois femininos), um laboratório de informática, uma biblioteca, uma sala para a diretoria e outra para a secretaria, além de uma sala de professores com dois banheiros, dois almoxarifados, uma cozinha, um refeitório, uma quadra coberta e dois pátios cobertos.

Nos últimos anos, as oficinas funcionam de $12 \mathrm{~h} 30$ as $15 \mathrm{~h} 30$. Até o ano de 2015, acontecia uma oficina por dia e a cada bimestre os alunos trocavam de oficina. A partir de 2016, ano da realização da pesquisa, eles passaram a participar de duas oficinas por dia e trocavam de atividades a cada semestre, sendo que algumas oficinas eram programadas para serem ministradas durante o ano inteiro, caso, por exemplo, da oficina de teatro, em que, ao final de cada do ano, os alunos fazem uma apresentação teatral. 
Na primeira semana de aulas, os alunos escolhem as oficinas de que irão participar durante o semestre e a essa prática da escolha dos alunos foi dado 0 nome de GIROS. A ideia é que eles, durante os anos que passam pela escola, possam vivenciar várias atividades. As turmas das oficinas têm entre 10 e 20 alunos e, quando existe uma procura muito grande por uma mesma oficina, é feito um sorteio e os alunos não sorteados são encaminhados a outra oficina que tenha vaga. As oficinas têm duração de $1 \mathrm{~h} 20$, portanto, os alunos participam de duas oficinas por dia, conforme citado anteriormente.

Essas atividades são ministradas pelos professores efetivos ou pelos contratados, pertencentes ao quadro da Rede Municipal de Educação, ou seja, são docentes da escola, portanto, não ocorre como no Programa Mais Educação, promovido pelo Governo Federal (iniciado em 2007), que funciona com oficineiros: pessoas contratadas para ministrar oficinas específicas por um determinado tempo ${ }^{17}$. Ao consultar as oficinas oferecidas pela escola, é possível notar algumas semelhanças entre elas e os Macrocampos, propostos pelo Programa Mais Educação, porém, o tempo integral na escola existe independentemente dessa política de âmbito federal.

A escola oferece as seguintes oficinas: Projeto de Xadrez, Projeto AfetivoSexual, Projeto Contadores de História, Projeto de Fotografia, Projeto Meio Ambiente, Projeto de Informática, Projeto Fios da História, Projeto de Leitura, Projeto de Artesanato, Projeto de Teatro, Projeto Mãos na Terra (de plantação e cultivo de uma horta) e Estudos Orientados (reforço de Língua Portuguesa e Matemática - obrigatório para os alunos do 9aa).

É importante salientar que, no início de cada ano, os professores responsáveis pelos projetos apresentam no conselho de classe como serão desenvolvidas as atividades daquele ano. No caso do projeto que serviu para a pesquisa de campo - os Contadores de História - houve a proposta da professora de que, no ano de 2016, as oficinas seriam com visualização de filmes e não com leitura ou contação oral de estórias, como nos anos anteriores.

No final do ano letivo, há uma semana em que os resultados das oficinas são apresentados para toda a comunidade escolar, como uma forma de socialização das atividades e das produções realizadas. É importante destacar que as turmas dos projetos são mistas, compostas por alunos do 6ํㅡㅁ ao 9ำ anos.

\footnotetext{
${ }^{17}$ As escolas da rede pública de todo o país podem aderir ao Programa Mais Educação através do site PDDE Interativo, uma ferramenta de apoio à gestão escolar oferecido para todas as escolas públicas do país. O site está disponível em: <http://pddeinterativo.mec.gov.br>. Acesso em: 22 nov. 2014.
} 


\section{2 0 entorno da escola}

Para caracterização dos sujeitos da pesquisa, é necessário entender o ambiente em que vivem e o bairro onde está localizada a escola. $O$ bairro $Y^{18}$, onde atualmente está situada a escola pesquisada, fica na zona oeste da cidade, uma das oito regiões administrativas em que a cidade é dividida pelo Plano Diretor elaborado pela prefeitura de Juiz de Fora com participação dos agentes sociais e que foi revisto no ano de 2015. Segundo dados do "Mapa Social de Juiz de Fora" (Juiz de Fora, 2012), o bairro fica a 14,5 quilômetros do centro da cidade. A região oeste é caracterizada da seguinte forma:

É localizada no sentido leste-oeste, do Morro do Imperador até a Bacia do Córrego São Pedro. [...] A área é composta por 27 bairros urbanos, dentre estes destacamos a existência de 10 condomínios, 01 região rural - Lagoa e 01 parcialmente rural - Recanto dos Bruggers. Este território encontra-se em grande fase de expansão, devido à sua posição geográfica de acesso pela Avenida Independência, BR 040 e UFJF. (Juiz de Fora, 2012, p. 145).

A seguir, apresento um mapa com a divisão das oito regiões da cidade:

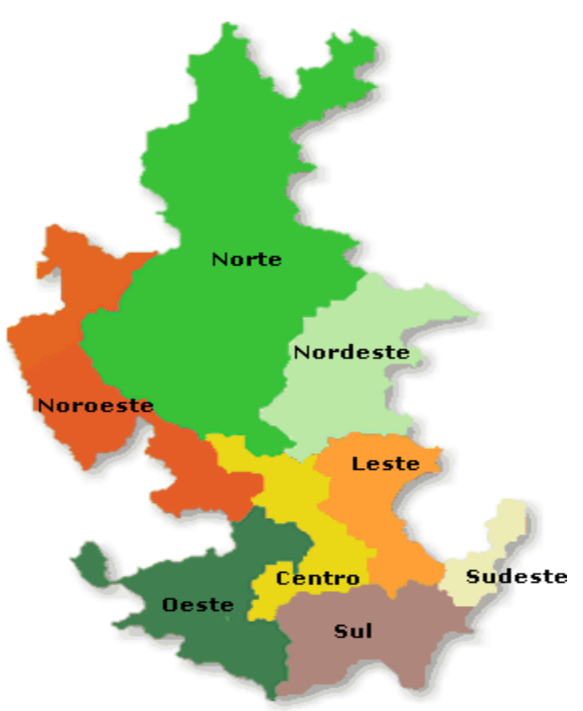

Figura 1 - Mapa administrativo de Juiz de Fora, dividido por regiões Fonte: Portal acessa.com.

A região oeste, em verde escuro no mapa, também conhecida como Cidade Alta, é dividida em 9 microrregiões, cujo nome de referência é a do bairro considerado de maior projeção, no caso da microrregião em que está localizado o bairro $\mathrm{Y}$ é denominada Novo Horizonte.

\footnotetext{
${ }^{18} \mathrm{O}$ bairro onde atualmente está situada a escola será chamado de $\mathrm{Y}$.
} 
É importante ressaltar que até o início dos anos 2000, muitos bairros da região oeste de Juiz de Fora eram formados basicamente de propriedades rurais e casas cujos proprietários usavam aos fins de semana para lazer e descanso, visto que é uma região mais afastada da região central da cidade e com muita área verde. A partir desse período, muitos loteamentos e casas populares foram sendo construídos na região, alguns inclusive com subsídios do Programa Minha Casa, Minha Vida do governo federal. Devido a isso, houve um crescimento desordenado na região, que não conta com espaços públicos de cultura e lazer, além disso, há muitas ruas sem asfalto e o transporte público é insuficiente. No caso do bairro onde a escola está situada, por exemplo, não há uma linha de ônibus que atenda exclusivamente esse bairro, com cinco linhas coletoras de outros bairros que passam por ali.

Vale, ainda, destacar que esse crescimento populacional na região foi bastante criticado, principalmente, pelos donos das "casas de fim de semana", que se preocuparam com a desvalorização de seus imóveis. A nota intitulada "Fora de Lugar", publicada na coluna social do jornal "Tribuna de Minas", de maior circulação na cidade, ilustra bem esse conflito: A construção de um conjunto habitacional financiado pelo programa "Minha Casa,
Minha Vida", do Governo Federal, na Nova Califórnia, está tirando o sono de
muitos moradores do bairro. Situado em plena Cidade Alta, o terreno escolhido
para o projeto - na Rua Nestor Vasconcellos Neto - fica em meio a uma área
residencial nobre, composta de granjas e casas de elevado padrão de construção.
Uma região que, por sinal, não atende aos requisitos do programa, por não estar
próxima à escola, creche, posto de saúde e nem dotada de várias linhas de
transporte coletivo. Preocupados com a notícia-surpresa, os proprietários de
imóveis próximos ao local estão se mobilizando, inicialmente com abaixo-
assinado, no sentido de reverterem a iniciativa, fruto de parceria entre a Caixa
Econômica Federal e a Prefeitura. (Tribuna de Minas, 5 de setembro de 2010,
s/pág.).

A nota se refere ao bairro Nova Califórnia, um dos bairros da cidade alta, e indica o quanto os moradores recém-chegados à região e que ocuparam as moradias populares sofreram resistência de outros grupos economicamente favorecidos.

O único equipamento público situado no bairro é a escola pesquisada, que tem cumprido um papel que vai além do ensinar, promovendo atividades culturais nos projetos de contraturno que, muitas vezes, são a única fonte de aproximação dos jovens estudantes com a produção cultural (dança, teatro, capoeira, cinema e outros). Além disso, eventualmente a escola promove atividades para as mães dos alunos, ressaltando, dessa forma, que seu papel social vai além das atividades envolvendo os alunos, mas numa perspectiva de aproximar a família do ambiente escolar. 
Outros equipamentos públicos, como praça e posto de saúde estão localizados no Bairro São Pedro, que é o lugar de referência de toda a região oeste, situado a $3 \mathrm{~km}$ do bairro onde a escola está localizada. Este último não conta com uma escola que atenda aos alunos do ensino médio. Segundo relatos dos jovens da escola pesquisada, ao terminarem o ensino fundamental, a escola recomenda que eles se matriculem na escola estadual situada no bairro São Pedro, porém, segundo eles, há uma rivalidade entre os jovens dos dois bairros. Em função disso, muitos familiares deles, que estão no ensino médio, preferiram estudar nas escolas próximas do centro ou da zona sul da cidade.

Na região, há vários clubes campestres: Associação Portuguesa de Juiz de Fora (a $3 \mathrm{~km}$ do bairro), Sesc Pousada (a $1 \mathrm{~km}$ do bairro), Clube Campestre dos Bancários (a $3 \mathrm{~km}$ do bairro), entre outros, porém, nenhum deles é aberto ao público. O parque público mais próximo do bairro é o Parque da Lajinha, que fica a aproximadamente $5 \mathrm{~km}$ de distância e é um espaço onde a escola costuma levar seus alunos em datas comemorativas.

O cinema mais próximo do bairro fica a $6 \mathrm{~km}$ de distância e está localizado num shopping que atende às classes $A$ e $B$ da cidade, sendo considerado um lugar mais elitizado, o que, muitas vezes, inibe a presença de pessoas das classes populares. Há outro cinema, localizado em um shopping popular, que fica a 9 km de distância do bairro.

A UFJF está localizada a aproximadamente $6 \mathrm{~km}$ do bairro, porém, apesar da instituição desenvolver alguns projetos de extensão e cultura, nos últimos anos, para a comunidade em geral, ainda há um distanciamento do público que mora nos bairros do entorno e que não aposta na universidade como um espaço de democratização cultural. Há mais de uma década, foi criado o programa de extensão Boa Vizinhança, com o intuito de oferecer cursos de línguas, prévestibular, atendimento médico, nutricional e muitos outros à população em geral e preferencialmente aos moradores dos bairros mais próximos da universidade.

A Pró-Reitoria de Cultura da universidade tem promovido, mais enfaticamente no último ano, dois projetos para atender ao público do entorno da universidade: o Som Aberto e o Domingo no Campus. O primeiro acontece mensalmente aos sábados na Praça Cívica da universidade e, além de contar com uma feira de artesanato, oferece música, teatro, dança e várias atrações culturais. O segundo ocorre no mesmo espaço e conta com atividades para atender também ao público infantil, com várias atividades de recreação.

A partir da descrição feita que situa o bairro e a região onde a escola pesquisada está localizada, é possível perceber o quanto o espaço da escola 
torna-se importante para o público atendido por ela e a centralidade que ela tem na vida dos sujeitos desta pesquisa.

\section{3 \\ Os atores envolvidos}

Para conhecer os jovens participantes da pesquisa e traçar um perfil socioeconômico deles, recorri aos dados do questionário socioeconômico que os alunos da escola preencheram ao fazer a Prova Brasil ${ }^{19}$. Usei os dados do questionário da edição 2015, disponibilizados pelo $Q E d U^{20}$, com 51 questões que envolvem desde a idade do respondente, até o número de cômodos da sua casa e seus hábitos de leitura. O questionário é divido em duas áreas: Perfil (subdividido em Sociocultural, Econômico e Cotidiano) e Estudos (Trajetória, Incentivo e Deveres).

Para caracterizar o perfil socioeconômico dos atores envolvidos na pesquisa, mencionarei mais especificamente as questões que tratam do perfil do respondente, visto que estas estão mais diretamente relacionadas a esta pesquisa. É importante destacar que na edição 2015, duas turmas da escola deveriam ter feito a Prova Brasil e como a turma de 9ำ ano tinha menos de 20 alunos - número mínimo exigido para participação na prova -, apenas os alunos do 5a ano participaram e responderam ao questionário. Ressalto que o aluno deve comparecer à prova, mas não necessariamente responder ao questionário; nessa edição, apenas 17 alunos o fizeram. As questões respondidas pelos alunos que serão tomadas como referência para caracterização socioeconômica dos sujeitos desta pesquisa.

As questões de 5 a 13, que tratam dos bens de consumo das famílias, faz um levantamento dos aparelhos eletrônicos que os alunos possuem em suas casas, além de pesquisar se suas famílias têm automóvel próprio.

A partir das questões que tratam dos bens de consumo, respondidas pelos alunos, é possível verificar que todos eles têm geladeira e máquina de lavar em

\footnotetext{
19 A Prova Brasil é um exame nacional em larga escala criado em 2005 pelo Ministério da Educação. É complementar ao Sistema Nacional de Avaliação da Educação Básica e um dos componentes para o cálculo do Índice de Desenvolvimento da Educação Básica (Ideb). É aplicada aos alunos do $5^{\circ}$ e 9ำ anos de todas as escolas públicas do país que atendam às prescrições de aplicação, como, por exemplo, número mínimo de alunos em cada ano.

${ }_{20}$ Site criado pela Fundação Lemman e Merit Educacional, que disponibiliza e analisa os dados de avaliações educacionais em Larga Escala. Ressalto que, para esta pesquisa, usei apenas o material bruto disponibilizado pelo site, não me interessando pelas análises feitas, visto que meu objetivo é traçar um perfil socioeconômico dos sujeitos que frequentam a escola pesquisada.
} 
casa, que a maioria tem pelo menos dois aparelhos de televisão, um aparelho de rádio e um aparelho videocassete e/ou DVD. Chama atenção que um dos alunos não tenha nenhum aparelho de TV em casa, o que demonstra que, apesar de ser um bem popularizado, ainda há aqueles que não têm acesso nem aos canais de TV aberta. A pesquisa ainda aponta que grande parte das famílias dos jovens respondentes não tem carro, ou seja, depende do transporte público. Quase metade dos alunos não tem computador em casa, grande parte deles tem apenas um, sendo assim, para esse público, o computador não é um aparelho pessoal, sendo compartilhado com outros membros da família.

Pelos dados do questionário, é possível concluir que os respondentes vivem em condições básicas, ou seja, todos têm banheiro em casa, as casas têm pelo menos um quarto e um deles conta com empregada doméstica todos os dias da semana para realizar as tarefas do dia a dia.

Entre os respondentes, $70 \%$ moram com três ou mais pessoas em suas casas; ao relacionar o número de cômodos e bens de consumo presentes nas casas desses jovens com o número de moradores, fica evidente que grande parte deles divide quarto, banheiro, computador, rádio, videocassete e/ou DVD e televisão com outros membros da família, o que evidencia uma estrutura econômica básica, ou seja, características de classes populares que têm acesso aos bens de consumo, mas não em grande escala.

A questão de no 42 aborda a relação dos respondentes com o trabalho: "Atualmente você trabalha fora de casa (recebendo ou não um salário)?"; 3 estudantes responderam que sim. Levando em conta que eles estão no início do ensino fundamental II, este é um dado preocupante, pois muitos alunos trabalhadores acabam abandonando a escola antes de terminar o ensino médio.

Ao tratar da relação dos jovens com o trabalho, Corrochano (2014) aponta que eles, muitas vezes, entram no mercado de trabalho de maneira precária, em atividades cujo salário é muito baixo, pois ainda não têm qualificação para concorrer a postos de mais prestígio e estabilidade. A autora afirma que "Até os 16 anos, qualquer tipo de inserção no mercado de trabalho é proibida no Brasil, salvo nas condições de aprendiz (entre 14 e 15 anos)." (Corrochano, 2014, p. 215). Por isso, a questão fala do trabalho informal, quando usa a expressão "recebendo ou não um salário", pois é provável que esses alunos façam trabalhos informais, os chamados "bicos". Ainda segundo Corrochano (2014, p. 213):

No Brasil, assim como em países da América Latina, a transição para o trabalho depois de finalizada a escolaridade básica não é uma realidade e duas 
características importantes marcam a relação entre escola e trabalho no país: o ingresso precoce no mercado e a conciliação ou superposição de estudo e trabalho. Aqui, boa parte dos jovens envolve-se com o trabalho e, especialmente, com os bicos desde muito cedo, mobilizando múltiplas estratégias para ganhar a vida. (Grifos no original).

Os dados apresentados a seguir sobre a caracterização dos sujeitos desta pesquisa tratam de suas experiências e práticas cotidianas em relação ao audiovisual. Vale ressaltar que eles foram obtidos a partir de um questionário com 16 questões (Apêndice B), que foi respondido em um dos primeiros encontros realizados na pesquisa de campo. No início das atividades do projeto, participavam 27 jovens e foram estes que responderam o questionário; depois houve um acréscimo de cerca de dez alunos, mas o perfil geral das turmas não mudou. Nesse primeiro momento, 14 meninas e 13 meninos participaram das atividades da pesquisa de campo e as idades variaram entre 10 e 14 anos, conforme o gráfico a seguir:

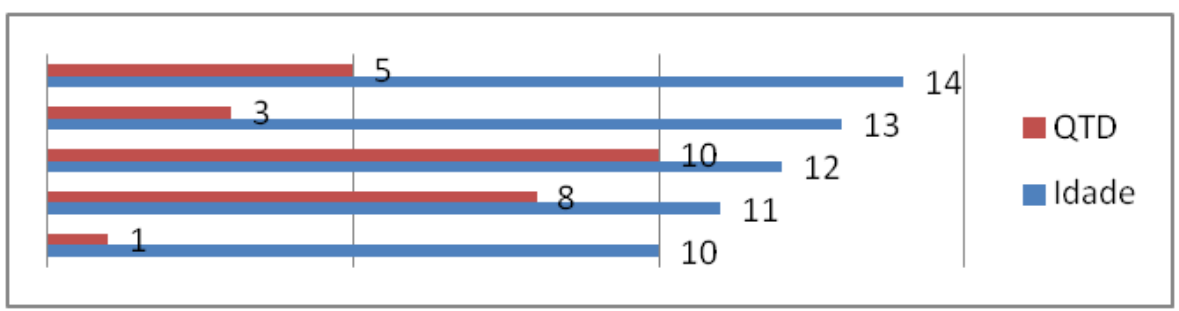

Gráfico 1 - Idade dos participantes da pesquisa

Fonte: Elaboração própria com base nos dados da pesquisa.

Conforme exposto anteriormente, as turmas eram mistas: participaram das atividades do primeiro semestre 2 alunos do $9^{\circ}$ ano, 3 alunos do $8^{\circ}$ ano, 11 do $7^{\circ}$ ano e 11 do $6^{\circ}$ ano.

Ao serem perguntados se viam filmes quando eram crianças, apenas um dos jovens respondeu que não. Em relação à idade que começaram a ver filmes, o gráfico a seguir apresenta os dados recolhidos no questionário:

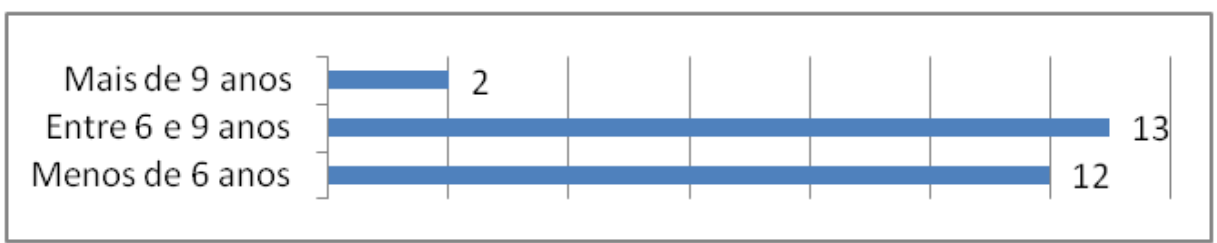

Gráfico 2 - Idade em que os jovens começaram a ver filmes Fonte: Elaboração própria com base nos dados da pesquisa.

Praticamente metade dos sujeitos da pesquisa respondeu que começou a ver filmes antes dos 6 anos de idade; 13 responderam que começaram a assistir entre 6 e 9 anos e apenas dois respondentes afirmaram ter começado a assistir 
a filmes depois dos 9 anos de idade. Esses dados confirmam a pesquisa de Sarmento (2008) que, ao tratar da relação de crianças de uma instituição de saúde com o cinema, constata que estes se estabelecem muito precocemente, amparados pelos modos de ver TV. Ou seja, apesar de grande parte dos sujeitos da pesquisa não ter tido contato próximo e frequente com o cinema, esses contatos haviam sido intensamente mediados pela TV, plataforma em que assistem a filmes.

Ainda sobre a relação das crianças com o audiovisual, a pesquisa realizada pelo Grupo de Pesquisa em Educação e Mídia (Grupem) da PUC-Rio, cujo objetivo era saber o que as crianças pensam sobre o que veem na TV, aponta que a TV aberta no Brasil está presente em $98 \%$ dos lares brasileiros. A partir dos dados dessa pesquisa:

As crianças compõem o segmento mais significativo de espectadores de televisão (estimativas realizadas pelo IBOPE sugerem que espectadores de 8 a 14 anos representam o maior percentual de público das telenovelas, incluindo as exibidas em horário nobre, em geral classificadas como inadequadas para essa faixa de idade). Canais especialmente voltados para crianças (Cartoon Network, Fox Kids, Discovery Kids, Disney Chanel, Nickelodeon, entre outros) são veiculados pela tevê por assinatura, com programação destinada a atender ao "gosto" infantil vinte e quatro horas por dia. Cerca de $48 \%$ das crianças que participaram da pesquisa relatada neste livro afirmam ter em casa tevê por assinatura, a cabo ou via satélite (Migliora, 2007). No Brasil, crianças e adolescentes de diferentes camadas sociais são maioria na locação de filmes [...]. (Duarte, 2008, p. 17-18).

Quanto ao local em que viam filmes, os participantes da pesquisa tinham três opções para responder: (1) em casa (TV, DVD); (2) na casa de amigos ou parentes; (3) no cinema. A alternativa 2 não foi marcada por nenhum dos respondentes. Os dados encontrados confirmam as pesquisas de Sarmento (2008) e do Grupem (Duarte, 2008). O gráfico a seguir apresenta os resultados desta questão:

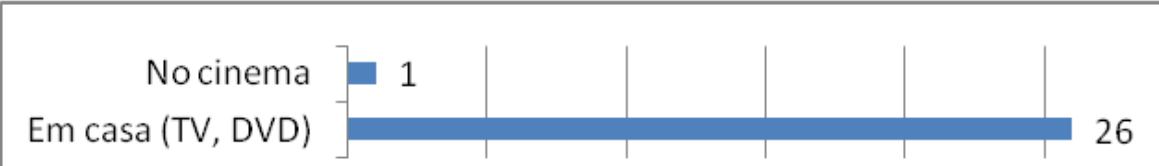

Gráfico 3 - Onde os jovens informaram ver filmes na infância Fonte: Elaboração própria com base nos dados da pesquisa.

Perguntados se gostam de assistir a filmes, todos responderam sim e essa resposta corrobora a opção pela oficina, pois eles tinham conhecimento de que durante o ano de 2016, o projeto Contadores de Histórias seria de visualização de filmes. 
Sobre o fato de os alunos irem ao cinema quando eram crianças, as respostas foram organizadas no gráfico a seguir:

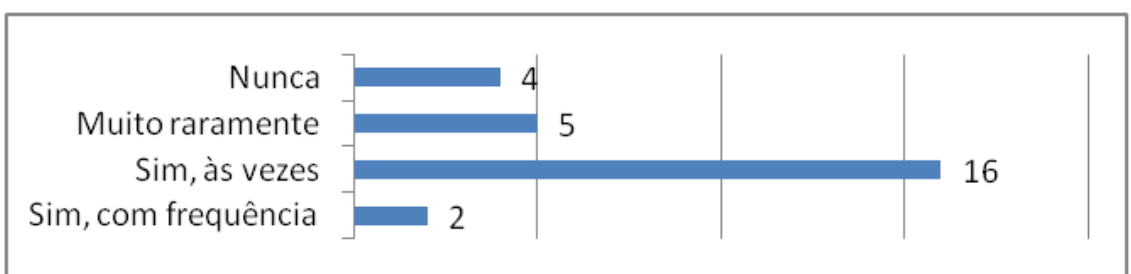

Gráfico 4 - Frequência com que os jovens iam ao cinema na infância Fonte: Elaboração própria com base nos dados da pesquisa.

Quando perguntados com quem iam ao cinema, 15 alunos responderam que iam com os pais, 7 que iam em atividades promovidas pela escola e outros 5 deram respostas variadas. Perguntados se costumam ir ao cinema atualmente, 15 responderam que sim e 12 participantes, que não. As respostas a essas duas questões indicam que, apesar de assistirem a filmes, muitos não frequentam salas de cinema, ou seja, assistem a filmes principalmente em outros lugares; sinalizam também que a escola é a responsável por muitas das atividades culturais de que eles participam fora do ambiente escolar.

Foi possível justificar essas questões levantadas ao analisar as respostas que tratam da frequência em que esses alunos vão ao cinema, como mostra o gráfico a seguir:

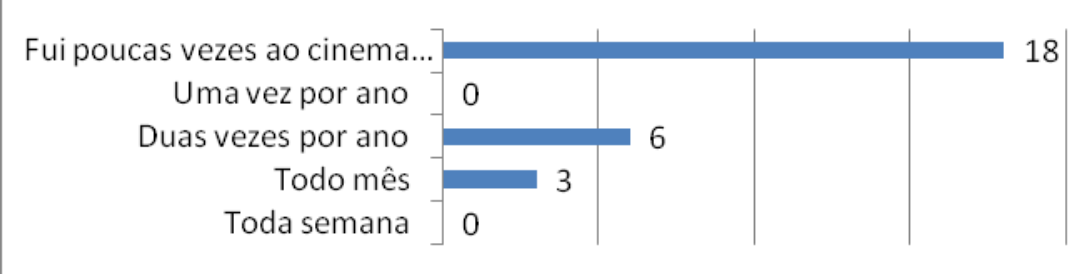

Gráfico 5 - Frequência com que os jovens vão ao cinema

Fonte: Elaboração própria com base nos dados da pesquisa.

Grande parte deles (18 alunos) foi poucas vezes ao cinema e apenas três jovens responderam que vão ao cinema todo mês. A partir das respostas dos alunos, foi possível concluir que para eles, a TV é o contato mais direto com filmes, o que confirma os estudos de Martín-Barbero, Orozco e outros autores que apontam o quanto a TV tem enorme relevância no Brasil e nos demais países da América Latina.

A "Pesquisa brasileira de mídias", encomendada pela Secretaria de Comunicação da Presidência da República (Secom), em 2014, aplicada junto a 18 mil entrevistados pelo Instituto Brasileiro de Opinião Pública e Estatística 
(lbope), afirma que a televisão é a mídia mais acessada pelo brasileiro. Segundo a pesquisa, 95\% dos entrevistados afirmam ver TV, com a média diária de tempo de consumo dos brasileiros: 4h30.

É importante destacar que, no Brasil, há muitas cidades que não têm nenhuma sala de cinema, isso faz com que a única maneira de assistir a filmes seja a TV, pois é também a forma mais barata de ter acesso a filmes. Dados da Ancine (2015) revelam, por exemplo, que 50\% do público que vai ao cinema está nos estados do Rio de Janeiro e São Paulo, onde encontram-se aproximadamente $50 \%$ das salas de cinema do país. Em contrapartida, o Estado do Acre, na região Norte, tem apenas 5 salas de cinema. O Estado de Minas Gerais, onde a pesquisa foi realizada, conta hoje com $8 \%$ do total de salas de cinema do território nacional. Em Juiz de Fora há aproximadamente 15 salas de cinema, todas elas em shoppings centers ou complexos pertencentes a grandes empresas exibidoras (Cinemark, Kinoplex, Cinemais e outras) ${ }^{21}$.

Além do acesso limitado, devido ao número reduzido de salas, o ingresso de cinema teve o valor médio nacional calculado em 2015 em $R \$ 13,59$ (Ancine, 2016), porém este é o valor médio, pois há salas com ingresso acima de $R \$$ 40,00 , o que pesa no orçamento familiar, visto que os pais pagam seus ingressos e os dos filhos, isso dificulta a presença constante de famílias de classes populares nas salas de cinema.

A pesquisa "MídiaFatos", realizada em 2013 e divulgada em 2014, aponta que o público consumidor de TV por assinatura está mais concentrado nas classes $A B$, há predominância do público masculino, e do público infantil e os assinantes estão na faixa etária entre 25 e 49 anos (ABTA, 2014).

Em relação à classe econômica dos consumidores de TV por assinatura no Brasil, a "MídiaFatos 2014" aponta os seguintes dados: 49\% são da classe B, $36 \%$ na classe $\mathrm{C}, 12 \%$ na classe $\mathrm{A}$ e $3 \%$ na classe D. Esses dados nos remetem a um afirmação de Martín-Barbero (2013) que diz que os mais ricos, ou seja a classe A, tendem a usar a TV principalmente para informação, pois não necessitam dela para ter acesso aos meios culturais, pois têm acesso a outros dispositivos culturais como cinema, teatro, livros.

A informação da pesquisa MídiaFatos pode ser confirmada pela pesquisa "Cultura em Números" (2010), que aponta como público mais frequente às salas de cinema, aquele de renda mais elevada, chegando a $21 \%$ de frequência por

${ }^{21}$ O último cinema de rua de Juiz de Fora, o Cinearte Palace, com exibidor independente foi fechado no dia 14 de junho de 2017. Neste espaço funcionava o Cube do Professor (com ingressos mais baratos para professores e uma sessão gratuita aos sábados) e a Sessão Cidadão (com ingressos a $R \$ 1,00$ ): dois projetos que visavam à formação de público. 
renda. No caso do número reduzido de membros da classe $\mathrm{D}$ com TV por assinatura, deve-se ao custo desta; estes, provavelmente, desfrutam apenas dos canais abertos de TV.

A MídiaFatos destaca ainda que São Paulo, Rio de Janeiro e Brasília são as cidades com maior número de assinantes de TV paga, seguidos por Porto Alegre e Florianópolis. Segundo essa agência há uma predominância dos canais de filmes e séries, que são, ao todo, 58 .

Dessa forma, é possível entender que grande parte do público de TV por assinatura assiste a filmes e séries, visto que há um bom número de ofertas deste gênero, pois dos 199 canais disponíveis, mais de 25\% são de filmes e séries, como mostra o quadro a seguir:

\begin{tabular}{|l|c|}
\hline \multicolumn{1}{|c|}{ Gênero } & $\begin{array}{c}\text { Quantidade de canais de } \\
\text { TV por Assinatura }\end{array}$ \\
\hline Filmes e séries & 58 \\
\hline Esportivos & 25 \\
\hline Infantojuvenil & 18 \\
\hline Variedades e entretenimento & 16 \\
\hline Lifestyle & 14 \\
\hline Documentários/ Factuais & 13 \\
\hline Étnicos & 11 \\
\hline Eróticos & 10 \\
\hline Jornalísticos e informativos & 08 \\
\hline Poder público & 07 \\
\hline Entretenimento jovem & 05 \\
\hline Musicais & 05 \\
\hline Educativos e profissionalizantes & 04 \\
\hline Agrobusiness & 03 \\
\hline Televendas & 01 \\
\hline Meteorológico & 01 \\
\hline Quadro 1 Canais de TV por assinatura div
\end{tabular}

Quadro 1 - Canais de TV por assinatura divididos por gênero

Fonte: Elaborado pela autora a partir dos dados de MídiaFatos (ABTA, 2014).

A questão em que são perguntados em que plataforma assistem a filmes com mais frequência, confirma a inferência de que está na TV aberta o principal acesso dos jovens desta pesquisa aos filmes, conforme expresso no gráfico: 


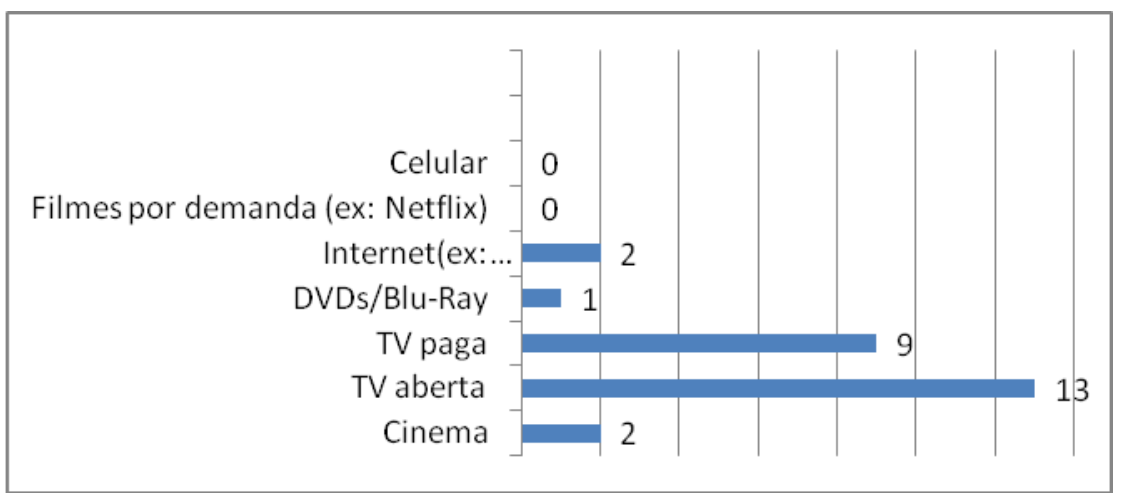

Gráfico 6 - Dispositivos em que os jovens assistem a filmes com mais frequência

Fonte: Elaboração própria com base nos dados da pesquisa.

Perguntados sobre quantos filmes eles assistem por semana, foi possível perceber que assistem a quase um filme por dia:

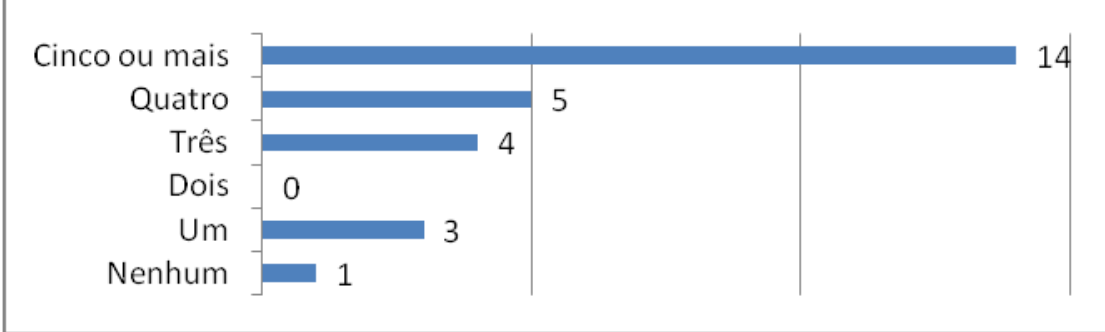

Gráfico 7 - Média do número de filmes que os jovens assistem por semana Fonte: Elaboração própria com base nos dados da pesquisa.

Quando perguntados se costumam assistir a filmes na escola, 21 responderam que sim e apenas 6 disseram que não. Perguntados, ainda, se os filmes assistidos na escola estavam relacionados a alguma disciplina, 23 responderam que sim e apenas 4 disseram não. Ao serem questionados sobre quais disciplinas eram essas, as que mais apareceram foram: história, ciências e os projetos de fotografia e afetivo-sexual.

A penúltima questão do questionário era aberta e solicitava que eles escrevessem o nome do último filme que viram e as respostas foram as seguintes: 


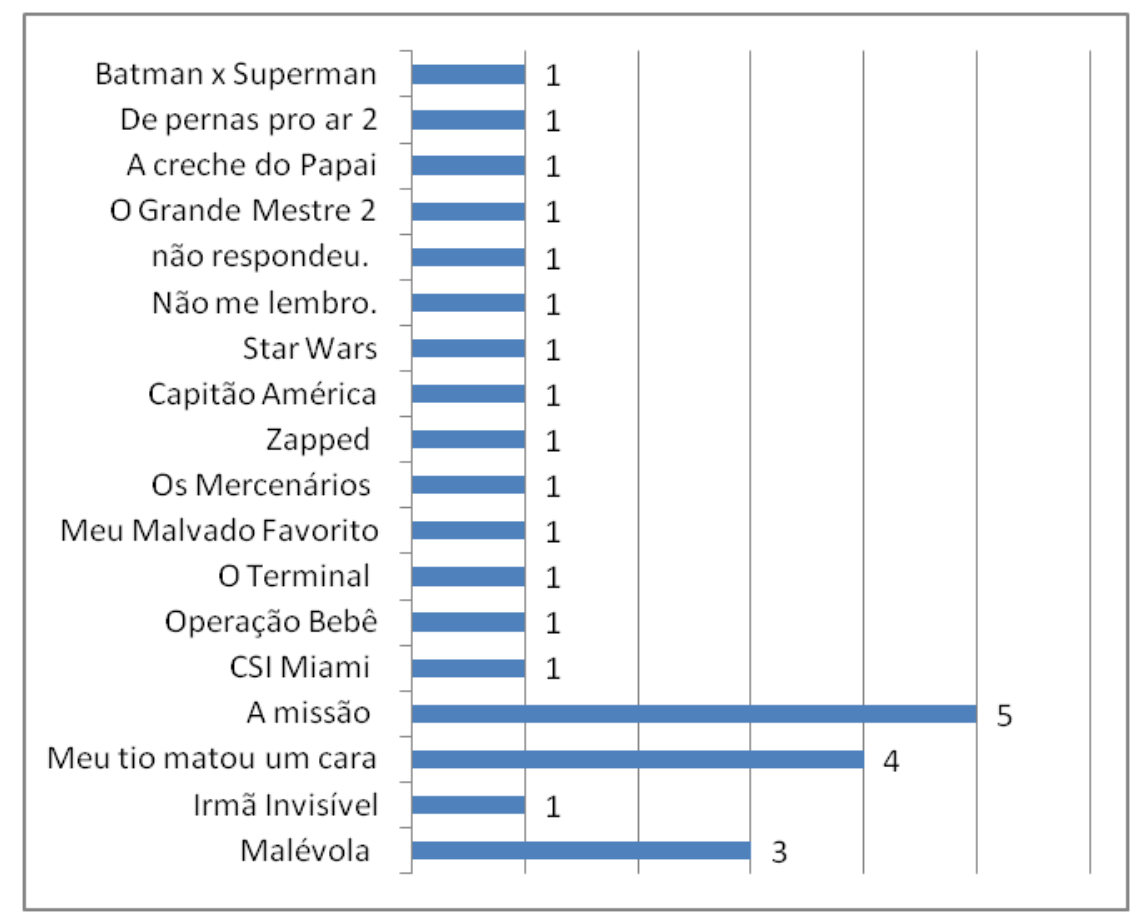

Gráfico 8 - O último filme a que os jovens assistiram

Fonte: Elaboração própria com base nos dados da pesquisa.

Vale destacar que o filme mais visto pelos alunos, $A$ missão (Roland Joffé, 1986) foi exibido na escola e faz parte do conteúdo da disciplina de História ${ }^{22}$; dos 27 alunos, 5 responderam ser este o último filme que viram, 3 participantes disseram ter visto Malévola, que era o filme que estava sendo visualizado na oficina desta pesquisa.

A última questão, também aberta, solicitava a eles que escrevessem o nome de um filme que eles gostariam de assistir e 6 jovens responderam que não tinham nenhum filme que gostariam de ver. É interessante notar que 17 filmes foram citados, sendo apenas três deles brasileiros: 1) O escaravelho do Diabo (Carlos Milani, 2016), filme baseado num livro que eles estavam lendo no Projeto de Leitura e que estreou em 2016; à época do questionário, eles estavam se preparando para ir ao cinema assistir a este filme; 2) Os dez mandamentos (Alexandre Avancini, 2016), também estava em cartaz nos cinemas e com inúmeras propagandas em um canal de TV aberto, realizador do filme que foi adaptação de uma novela do canal; 3) Copa de elite (Vitor Brandt 2014), uma comédia que faz uma paródia do filme Tropa de elite (José Padilha, 2007). Os resultados de todas as respostas constam no gráfico a seguir:

\footnotetext{
${ }^{22}$ O filme trata das missões jesuíticas realizadas no Brasil no século XVIII e é classificado como um filme histórico.
} 


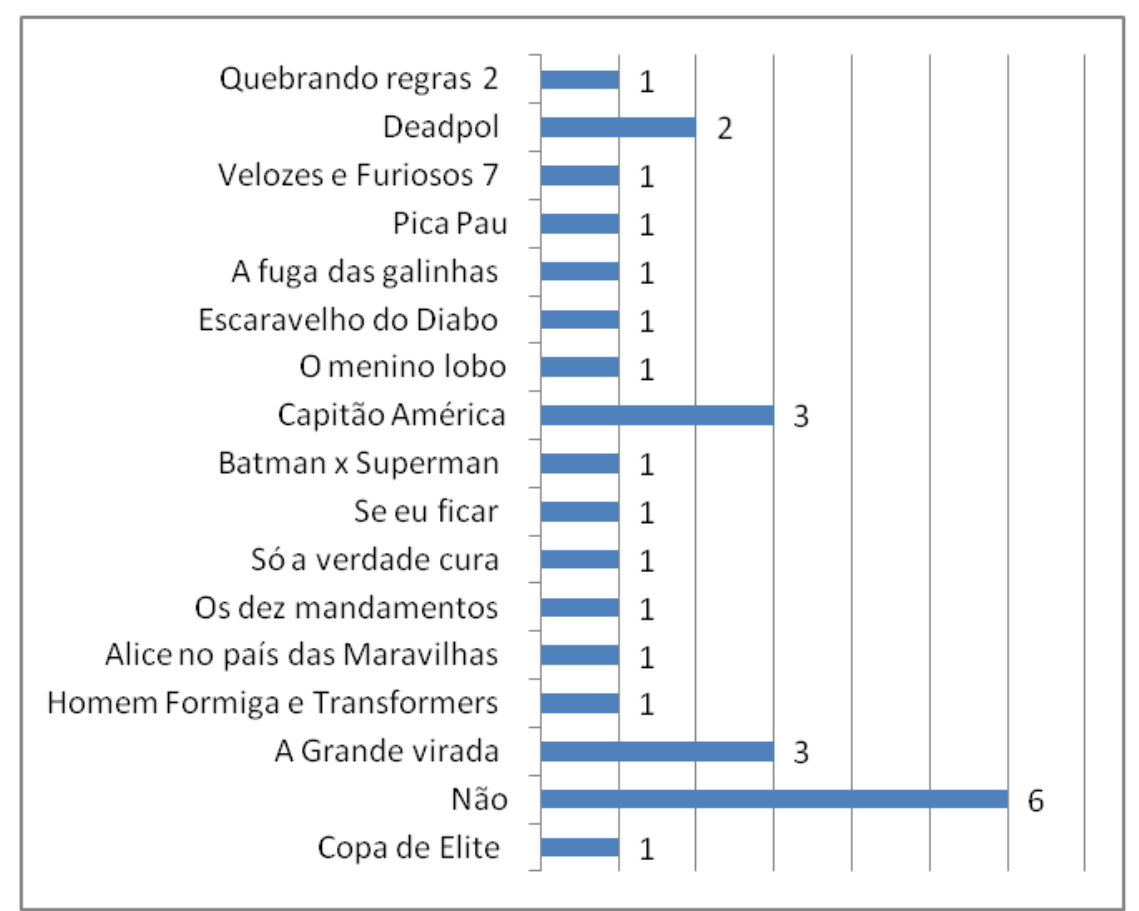

Gráfico 9 - Filmes a que os jovens gostariam de assistir Fonte: Elaboração própria com base nos dados da pesquisa.

A partir dos dados levantados no questionário, percebi que os jovens pesquisados não têm o hábito de ir ao cinema e, portanto, as atividades escolares que trabalham com visualização de filmes têm um significado bastante importante na formação deles, pois os filmes vistos na escola foram lembrados por muitos como sendo os últimos filmes que assistiram. É necessário destacar, ainda, que a TV aberta é o principal suporte desses sujeitos para visualização de filmes.

\section{4 \\ A pesquisa}

Para o desenvolvimento das atividades, fui à escola no dia 18 de fevereiro de 2016 para me apresentar à diretora, que se colocou à disposição para auxiliar na pesquisa. Aproveitei para conhecer os espaços da escola e a biblioteca, onde foi realizada grande parte das oficinas. O espaço da biblioteca me chamou atenção, pois à frente das prateleiras com livros há mesas redondas e não carteiras enfileiradas, o que deixa o ambiente mais descontraído e propício para o debate, para as atividades em grupo e para as discussões. Além disso, é uma sala que já é usada com frequência para exibição de filmes, portanto já há 
cortinas e, quando necessário, os alunos usam um tecido preto para deixar a sala mais escura.

Nesse dia, aproveitei também minha ida à escola para conhecer os jovens que participariam da pesquisa, eles estavam divididos em duas turmas, uma no primeiro horário que chamei de Turma 1 e outra no segundo horário, denominada Turma 2. Apresentei a proposta de exibição de filmes para os jovens e conversei com eles sobre a dinâmica, aproveitei para lembrá-los de que as atividades seriam áudio ou videogravadas em alguns momentos, mas que eles iriam se acostumar rapidamente com esses recursos.

Além desse encontro informal, tive outros 29 encontros com essas turmas para o desenvolvimento das oficinas de visualização de filmes, contando também com as oficinas de produção de um curta-metragem, que não estavam previstas inicialmente, mas surgiram como uma demanda dos alunos. Nosso último encontro ocorreu em 15 de dezembro de 2016 e todos serão brevemente relatados. As atividades ocorreram em grande parte na biblioteca às quintasfeiras. Em alguns dias, foi preciso mudar de sala para atender a algum professor que necessitava daquele espaço.

O quadro a seguir traz um resumo das atividades desenvolvidas na pesquisa de campo:

\begin{tabular}{|c|c|c|}
\hline & & Atividades desenvolvidas \\
\hline $11^{0}$ & & isualização da primeira hora do filme $A$ culpa é das estrelas. \\
\hline $2^{\circ}$ & 07/04 & $\begin{array}{l}\text { Visualização da segunda parte do filme } A \text { culpa é das estrelas e } \\
\text { dinâmica envolvendo a reescrita do roteiro com os elementos da } \\
\text { narrativa. }\end{array}$ \\
\hline $3^{\circ}$ & $28 / 04$ & $\begin{array}{l}\text { Retomada da dinâmica do filme } A \text { culpa é das estrelas. } \\
\text { Entrega dos termos de consentimento para os alunos (Apêndice C) e } \\
\text { pais assinarem (Apêndice D). } \\
\text { Visualização do curta-metragem: Confusões de adolescente. }\end{array}$ \\
\hline $4^{\circ}$ & $05 / 05$ & me Malévola. \\
\hline $5^{\circ}$ & $19 / 05$ & $\begin{array}{l}\text { Aplicação do questionário sobre a experiência dos jovens com o } \\
\text { audiovisual e suas práticas cotidianas (Apêndice B). } \\
\text { Em função da falta de DVD na escola, os participantes da pesquisa } \\
\text { fizeram desenhos das personagens marcantes para eles e, divididos } \\
\text { em grupos, reencenaram uma parte do filme que tenha chamado sua } \\
\text { atenção. }\end{array}$ \\
\hline $6^{\circ}$ & 02/06 & $\begin{array}{l}\text { Visualização da segunda parte do filme Malévola. } \\
\text { Visualização dos minutos iniciais de X-Men: dias de um futuro } \\
\text { esquecido. }\end{array}$ \\
\hline $7^{\circ}$ & 09/06 & $\begin{array}{l}\text { Visualização da segunda parte de X-Men: dias de um futuro } \\
\text { esquecido. }\end{array}$ \\
\hline $8^{0}$ & 06 & e um futuro esquecido. \\
\hline 90 & $23 / 06$ & $\begin{array}{l}\text { ro esquecido e } \\
\text { ulgadas na TV }\end{array}$ \\
\hline
\end{tabular}




\begin{tabular}{|c|c|c|}
\hline & Data & Atividades desenvolvidas \\
\hline $10^{\circ}$ & 04/08 & $\begin{array}{l}\text { Discussão em torno das atividades do semestre anterior e proposta de } \\
\text { Desafio para o mês de setembro }{ }^{23} \text {. }\end{array}$ \\
\hline $11^{\circ}$ & $11 / 08$ & $\begin{array}{l}\text { Visualização da primeira parte de Jogos vorazes: a esperança - parte } \\
1 .\end{array}$ \\
\hline $12^{\circ}$ & $18 / 08$ & $\begin{array}{l}\text { Visualização da segunda parte de Jogos vorazes: a esperança - parte } \\
1 .\end{array}$ \\
\hline $13^{\circ}$ & $25 / 08$ & Visualização da parte final de Jogos vorazes: a esperança - parte 1. \\
\hline $14^{\circ}$ & $01 / 09$ & $\begin{array}{l}\text { Visualização da primeira parte do filme As crônicas de Nárnia: o Leão, } \\
\text { a Feiticeira e o Guarda-Roupa. Um dos filmes escolhidos pelos } \\
\text { participantes da pesquisa no Desafio de setembro. }\end{array}$ \\
\hline $15^{\circ}$ & $08 / 09$ & $\begin{array}{l}\text { Leitura e discussão de resenhas que tratavam do filme As crônicas de } \\
\text { Nárnia: o Leão, a Feiticeira e o Guarda-Roupa. Falta de equipamentos } \\
\text { para a projeção do restante do filme. }\end{array}$ \\
\hline $16^{\circ}$ & $15 / 09$ & $\begin{array}{l}\text { Visualização da parte final do filme As crônicas de Nárnia: o Leão, a } \\
\text { Feiticeira e o Guarda-Roupa somente para a Turma } 1 .\end{array}$ \\
\hline $17^{\circ}$ & $22 / 09$ & $\begin{array}{l}\text { Dinâmica do filme As crônicas de Nárnia: o Leão, a Feiticeira e o } \\
\text { Guarda-Roupa e visualização do filme João e Maria: caçadores de } \\
\text { bruxas (escolhido pelos participantes da pesquisa) para a Turma 1. A } \\
\text { Turma } 2 \text { terminou de assistir As crônicas de Nárnia: o Leão, a } \\
\text { Feiticeira e o Guarda-Roupa e fez a mesma dinâmica que a Turma } 1 \\
\text { fez no encontro anterior. }\end{array}$ \\
\hline $18^{\circ}$ & 29/09 & $\begin{array}{l}\text { Visualização do restante do filme João e Maria: caçadores de bruxas } \\
\text { para a Turma } 1 \text { e dinâmica envolvendo o roteiro do filme visualizado. } \\
\text { Visualização do filme João e Maria: caçadores de bruxas na Turma } 2 \text {. }\end{array}$ \\
\hline $19^{\circ}$ & $06 / 10$ & $\begin{array}{l}\text { Visualização da hora inicial de Jurassic World: o mundo dos } \\
\text { dinossauros na Turma } 1 \text {. } \\
\text { A Turma } 2 \text { terminou de assistir aos minutos finais de João e Maria: } \\
\text { caçadores de bruxas, fez a dinâmica sobre o filme e começou a ver o } \\
\text { filme Jurassic World: o mundo dos dinossauros. }\end{array}$ \\
\hline $20^{\circ}$ & $20 / 10$ & Primeira parte da Oficina de Produção de filmes com as duas turmas. \\
\hline $21^{\circ}$ & $21 / 10$ & Segunda parte da Oficina de Produção de filmes com as duas turmas. \\
\hline $22^{\circ}$ & $27 / 10$ & $\begin{array}{l}\text { Visualização da parte final de Jurassic World: o mundo dos } \\
\text { dinossauros (Turma 1). } \\
\text { Visualização de grande parte do filme Jurassic World: o mundo dos } \\
\text { dinossauros (Turma 2). }\end{array}$ \\
\hline $23^{\circ}$ & $03 / 11$ & $\begin{array}{l}\text { Visualização da parte final do filme Jurassic World: o mundo dos } \\
\text { dinossauros na Turma } 2 \text { e conversas sobre os filmes visualizados } \\
\text { durante o ano nas duas turmas e sobre o roteiro do filme que eles } \\
\text { estão produzindo. }\end{array}$ \\
\hline $24^{\circ}$ & $10 / 11$ & Novas conversas sobre o roteiro do filme em produção. \\
\hline $25^{\circ}$ & $24 / 11$ & Gravação do curta-metragem 3 Forces ${ }^{24}$ produzido pelos jovens. \\
\hline $26^{\circ}$ & $25 / 11$ & Gravação do curta-metragem 3 Forces produzido pelos jovens. \\
\hline $27^{\circ}$ & $01 / 12$ & $\begin{array}{l}\text { Visualização do filme As melhores coisas do mundo, indicado por mim } \\
\text { para os participantes da pesquisa. }\end{array}$ \\
\hline $28^{\circ}$ & $08 / 12$ & $\begin{array}{l}\text { Visualização da última parte do filme As melhores coisas do mundo e } \\
\text { atividade de análise do filme. }\end{array}$ \\
\hline $29^{\circ}$ & $15 / 12$ & $\begin{array}{l}\text { Apresentação do curta-metragem produzido pelos jovens para a } \\
\text { comunidade escolar. }\end{array}$ \\
\hline
\end{tabular}

Quadro 2 - Resumo dos encontros realizados na pesquisa

Fonte: Elaborado pela autora a partir dos dados de pesquisa.

\footnotetext{
${ }^{23} \mathrm{O}$ Desafio do mês de setembro consistia na escolha feita por eles dos filmes a serem exibidos em setembro. Foi feita uma votação dos filmes indicados por eles e os mais votados foram exibidos e discutidos. Os filmes indicados e os mais votados encontram-se relacionados no Apêndice A, nas notas de campo do $10^{\circ}$ encontro.

${ }^{24}$ O vídeo está hospedado no YouTube no endereço:

https://www.youtube.com/watch?v=swiZ7TObn2U\&t=335s. Acesso em: 10 mar. 2017.
} 
Todos os filmes visualizados durante as oficinas tinham jovens como protagonistas e a percepção dos jovens sobre esses filmes será discutida nos próximos capítulos, à luz do referencial teórico apresentado e tendo como suporte metodológico a análise de conteúdo, conforme já discutido em capítulo anterior.

\section{5}

\section{Eixos analíticos e categorias de análise}

A análise dos dados apontou a existência de cinco eixos analíticos. Quais sejam:

a) Padrão Estético-narrativo;

b) Formação do Gosto;

c) Padronização de Juventude;

d) Diferenças entre os filmes brasileiros e os estadunidenses;

e) Fantasia e magia versus realidade.

Os três primeiros eixos estão relacionados à padronização de juventude nos filmes estadunidenses visualizados e os demais às relações de identificação entre os jovens e os filmes.

Na categoria padronização de juventude, emergiu uma subcategoria que aborda a relação dos jovens com os super-heróis.

Nos capítulos seguintes estes eixos serão analisados a partir do referencial metodológico da análise de conteúdo e do referencial teórico apresentado no capítulo 3 desta tese. 


\title{
A política da estética ou a estética da política?
}

\author{
Em geral, a mídia cria um sistema de cultura organizado \\ segundo uma variedade de indústrias, tipos de gêneros e \\ subgêneros e ciclos de gênero. Nisso, segue o modelo da \\ produção industrial que é dividida em suas próprias regras, \\ convenções e fórmulas. (Kellner, 2001, p. 87-88).
}

Neste capítulo, além da análise dos três primeiros eixos analíticos, quais sejam: Padrão Estético Narrativo, Formação do Gosto e Padronização de Juventude com sua subcategoria que analisa a relação dos jovens com os super-heróis, cabe fazer uma discussão inicial tratando da força política e estética da indústria cultural e o quanto esta força influencia o gosto do espectador.

O título do capítulo nos levanta uma questão no intuito de provocar: é a política da estética que influencia o espectador ou a estética da política? Ao tratar da primeira conceituação, refiro-me à área de conveniência com os modos de apresentar, de narrar, dessa forma, há uma fórmula das narrativas audiovisuais e, de certa forma, tudo que se difere da fórmula cria um estranhamento, a política da estética, neste sentido está diretamente relacionada a um padrão e uma padronização estética, ou a partir da afirmação de Carrière (2014, p. 147): "Fazemos uma porção de filmes, talvez não criemos mais cinema algum. Perdemos o espírito de invenção, o espírito de aventura. [...] Ao permanecermos fiéis à forma, frequentemente traímos a essência".

O termo que trata da estética da política está relacionado à manipulação de como se faz uma narrativa sem perder o controle da audiência. O termo ainda pode ser explicado a partir da epígrafe deste capítulo que trata das convenções e fórmulas, este está diretamente ligado ao primeiro termo (política da estética), um complementa o outro e um existe em função do outro, se o primeiro relaciona-se à maneira de apresentar ao espectador determinada narrativa, o segundo diz da maneira com que se deve construir a narrativa para atender ao espectador. Nesta perspectiva, além da narrativa, há uma preocupação com o mercado, ou seja, as maneiras de apresentar o filme ao público. Envolve, portanto, não somente a produção, mas a divulgação da narrativa audiovisual. Segundo Carrière (2014, p. 20): "Numa mídia visual, nada é percebido mais imediatamente por uma plateia do que o velho efeito, algo já visto, algo já 
realizado. Ou as plateias o rejeitam, ou o acolhem como se fosse um velho amigo."

Neste capítulo, tratarei o quanto estes dois conceitos estão diretamente relacionados aos filmes visualizados pelos jovens participantes da pesquisa e o quanto este padrão estético narrativo os conforta.

\section{1 Padrão estético e narrativo ou a "reprodução do sempre igual"}

Os filmes assistidos pelos participantes desta pesquisa, durante as oficinas de visualização, seguem determinados padrões, tanto relacionados à produção, o que envolve as questões estéticas e de narrativa - ou a política da estética, quanto à distribuição, o que está ligado a questões de mercado e arrecadação a estética da política.

O filme A culpa é das estrelas, o primeiro visualizado na pesquisa, é equiparado, em matéria publicada pela Revista Veja (CARNEIRO, 2014) ${ }^{25}$, a outros filmes dramáticos de grandes bilheterias, como Titanic (James Cameron, 1997) e Menina de Ouro (Clint Eastwood, 2004). Na matéria, o ator que faz o personagem principal é comparado a Leonardo DiCaprio (ator de Titanic $^{26}$ ) e a atriz é lembrada pelo filme que protagonizou anteriormente, Divergente (Neil Burger, 2014). Todos esses elementos oferecem ao leitor os parâmetros que orientarão seu olhar. A matéria termina comparando o filme aos demais lançamentos do ano de 2014, direcionados ao público jovem:

$\mathrm{Na}$ contramão dos últimos sucessos infantojuvenis da literatura e do cinema, que apostam em tramas fantasiosas, com bruxos e vampiros, ou distopias violentas, John Green surge como um respiro honesto e que não subestima seu público. Os adolescentes perceberam isso e o escritor se tornou uma grife: seus livros são presença constante na lista de mais vendidos. A culpa é das estrelas não deverá ter uma continuação como outras séries teens. Porém, a carreira de Green no cinema está só começando e promete ser brilhante. (Carneiro, 2014, s/pág., grifos no original).

Em relação às questões de mercado que envolvem o lançamento, a divulgação, as cifras investidas e arrecadadas, além da exibição de um filme, é possível perceber, a partir do quadro a seguir, que os filmes vistos seguem um

25 Disponível em: <http://veja.abril.com.br/entretenimento/assim-como-o-livro-a-culpa-e-dasestrelas-e-filme-para-ser-sentido/>. Acesso em 24 jun. 2017.

26 Titanic foi um filme lançado em 1997 com enorme sucesso. Teve 14 indicações para o Oscar, recebendo 11 prêmios, incluindo Melhor Filme e Melhor Diretor. Com uma bilheteria total de 2,1 bilhões de dólares, este foi o primeiro filme a arrecadar mais de 1 bilhão mundialmente, permanecendo como filme de maior arrecadação da história por 12 anos, sendo ultrapassado por Avatar, do mesmo diretor, em 2009. 
mesmo padrão mercadológico, o que inclui o orçamento, passando pelo número de cópias e de salas que irá exibi-los, até a arrecadação em bilheteria: 


\begin{tabular}{|c|c|c|c|c|c|c|c|}
\hline Filme & $\begin{array}{l}\text { Orçamento (em } \\
\text { dólar) }\end{array}$ & Produtora & Distribuidora & $\begin{array}{c}\text { Ano de } \\
\text { lançamento }\end{array}$ & $\begin{array}{c}\text { Número de } \\
\text { ingressos } \\
\text { vendidos no } \\
\text { Brasil }\end{array}$ & $\begin{array}{c}\text { Número de } \\
\text { salas no Brasil } \\
\text { (estreia) }\end{array}$ & $\begin{array}{c}\text { Arrecadação } \\
\text { em bilheteria } \\
\text { mundial (em } \\
\text { dólar) }\end{array}$ \\
\hline A culpa é das estrelas & 12 milhões & $\begin{array}{l}\text { 20th Century } \\
\text { Fox }\end{array}$ & $\begin{array}{l}\text { 20th Century } \\
\text { Fox }\end{array}$ & 2014 & 6.165 .705 & 950 & 280 milhões \\
\hline Malévola & 180 milhões & Disney & Disney & 2014 & 5.755 .409 & 796 & 800 milhões \\
\hline $\begin{array}{l}X-M e n: \text { dias de um } \\
\text { futuro esquecido }\end{array}$ & 200 milhões & $\begin{array}{c}\text { 20th Century } \\
\text { Fox }\end{array}$ & $\begin{array}{c}\text { 20th Century } \\
\text { Fox }\end{array}$ & 2014 & 4.923 .664 & 1.419 & 748 milhões \\
\hline $\begin{array}{l}\text { Jogos vorazes: a } \\
\text { esperança - parte } 1\end{array}$ & 125 milhões & $\begin{array}{l}\text { Lionsgate } \\
\text { Films }\end{array}$ & Paris Films & 2014 & 4.755 .582 & 1.580 & 700 milhões \\
\hline $\begin{array}{l}\text { As crônicas de Nárnia: } \\
\text { o Leão, a Feiticeira e o } \\
\text { Guarda-Roupa }\end{array}$ & 180 milhões & Walden Media & $\begin{array}{l}\text { Disney/ } \\
\text { Buena Vista }\end{array}$ & 2005 & 2.726 .150 & 488 & 745 milhões \\
\hline $\begin{array}{l}\text { João e Maria: } \\
\text { caçadores de bruxas }\end{array}$ & 50 milhões & $\begin{array}{l}\text { Paramount } \\
\text { Pictures }\end{array}$ & $\begin{array}{l}\text { Paramount } \\
\text { Pictures }\end{array}$ & 2013 & 3.716 .154 & 509 & 226,3 milhões \\
\hline $\begin{array}{l}\text { Jurassic World: o } \\
\text { mundo dos dinossauros }\end{array}$ & 150 milhões & Universal & Universal & 2015 & 6.356 .559 & 1.001 & $\begin{array}{c}1 \text { bilhão } 671 \\
\text { milhões } 713 \text { mil } \\
208^{27}\end{array}$ \\
\hline
\end{tabular}

Quadro 3 - Dados de mercado dos filmes vistos pelos jovens nas oficinas

Fonte: Elaboração própria a partir de dados da Ancine ${ }^{28}$ e de sites especializados em cinema.

\footnotetext{
${ }^{27}$ O filme Jurassic World: o mundo dos dinossauros é a quarta maior bilheteria da história do cinema mundial. Fica atrás de Avatar (James Cameron, 2009), Titanic (James Cameron, 1997) e Star Wars: o despertar da força (J.J. Abrams, 2015).
}

${ }^{28}$ Disponível em: <http://ancine.gov.br>. Acesso em: 21 maio 2017. 
Dos sete filmes vistos, apenas dois não foram produzidos pelas seis grandes empresas de cinema de Hollywood, que formam a MPAA, e apenas um não é distribuído por nenhuma delas, o que evidencia a concentração de demandas em poucas empresas e confirma o investimento elevado na distribuição dos filmes, visto que, para cada sala em que o filme é distribuído, há necessidade de uma cópia da obra. Em países como o Brasil, em que a língua não é o inglês, essas cópias ainda dependem de legenda ou dublagem. Dessa forma, para atuar no mercado, é preciso forte poder econômico para aguardar o retorno do investimento vindo das bilheterias.

Todos os filmes vistos nas oficinas tiveram retorno de bilheteria maior do que pelo menos quatro vezes seu gasto de produção, ou seja, nenhum deles fracassou nas bilheterias. Vale destacar que $A$ culpa é das estrelas é considerado um filme com baixo orçamento e alto retorno em bilheteria, pois rendeu 23 vezes o seu orçamento, somente com o arrecadado nas bilheterias pelo mundo.

Os sete filmes estrearam no Brasil com exibição em no mínimo 450 salas, sendo que Jogos vorazes: a esperança - parte 1 bateu o recorde de salas (1.580) até aquele momento, ou seja, até 2014 , este foi o filme com o maior número de salas disponibilizadas no lançamento, o que equivale a mais da metade das salas de cinema do Brasil, que segundo a Ancine (2015), contava com 2.833 salas em funcionamento.

Para que seja possível dimensionar o poder mercadológico desses filmes e o espaço que eles ocupam no cenário brasileiro, ao comparar os dados deles com os do filme brasileiro mais assistido em 2014, Até que a morte nos separe 2

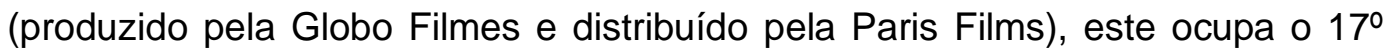
lugar no ranking de filmes mais vistos no país naquele ano, foi lançado em 778 salas e teve público de 2.930.693. Este é o único título brasileiro na lista dos 20 filmes de maior bilheteria no Brasil e seu público só é maior do que o filme $A s$ crônicas de Nárnia: o Leão, a Feiticeira e o Guarda-Roupa, que teve estreia em 488 salas brasileiras e é a produção mais antiga das sete assistidas, datada de 2005.

Segundo a Ancine (2015, p. 13): "Em 2014, 31 filmes estrangeiros e apenas três filmes brasileiros foram lançados em mais de 500 salas." Além disso, a agência indica que 9 filmes estrangeiros foram lançados em mais de mil salas, o que contribui para uma restrição do espaço para filmes brasileiros e de outras nacionalidades. 
O acesso fácil a filmes estadunidenses é também responsável pela formação estética dos espectadores: há uma maior facilidade para visualizá-los, pois estão em todas as salas de cinema e, em seguida, na TV, na internet e, em algumas cidades, em locadoras de DVD e há, ainda, a facilidade na visualização das narrativas, que são bastante lineares e de fácil compreensão. Além disso, a manutenção do padrão narrativo e do elenco tende a criar, para o espectador, uma espécie de "garantia de qualidade", que mantém o círculo vicioso do "mais do mesmo". Sobre a questão do acesso, vale recorrer à discussão proposta por Champangnatte (2016, p. 417):

A maioria das distribuidoras, que atuam no Brasil, é americana, inclusive, distribuem os próprios filmes nacionais. Isso interfere na quantidade de filmes brasileiros que vão para as salas de exibição, pois só são exibidos os que passam pelo crivo das distribuidoras, ou seja, os que têm características lucrativas. O diagnóstico é de que poucos filmes nacionais entram em cartaz no cinema brasileiro, sendo que há grande prevalência de filmes americanos, principalmente dos gêneros comédia e ação (AMORIM, 2011). A dominação americana nos cinemas nacionais, segundo Ballerini (2012), sempre ocorreu e faz parte das estratégias do cinema americano desde sua ascendência nos anos 1920. Porém, essa dominação foi intensificada a partir dos anos 1990, com o fechamento da EMBRAFILME pelo presidente Fernando Collor. A EMBRAFILME - Empresa Brasileira de Filmes - era uma empresa estatal que centralizava e financiava a produção, a distribuição e a exibição cinematográfica nacional.

Porém, é importante ter em mente que este não é só um problema brasileiro. Ao analisar o cenário do audiovisual francês do início dos anos 2000, Bergala (2008, p. 20) relata que:

A cultura do espectador estava mudando rapidamente com a chegada dos multiplex e dos cartões de fidelidade, e com o novo modo de relação com o filme que o DVD começava timidamente a introduzir. A concentração cada vez maior das redes de distribuição e de exibição deixava entrever um estado de oferta cinematográfica em que em que um terço das salas francesas acabaria por exibir na mesma quarta-feira, na mesma fatídica sessão das quatorze horas, o mesmo filme em milhares de salas ao mesmo tempo, deixando para os filmes menos bem dotados (de trunfos de sedução comercial ou verbas de lançamento) cada vez menos chances de encontrar seus espectadores. Onde a concorrência entre dois filmes se dava às vezes a 1.500 cópias contra 3.

Esse é, portanto, o cenário mundial do audiovisual, em que existe uma contundente e bem planejada estratégia de sedução na venda de um produto altamente lucrativo e de forte potencial de influência cultural. A culpa é das estrelas, por exemplo, foi lançado em 16 de maio de 2014, nos Estados Unidos, e 15 dias depois no Brasil, o primeiro trailer do filme foi divulgado em 29 de janeiro e teve mais de 3 milhões de visualizações em apenas 24h e 15 milhões uma semana depois. Além disso, a 20th Century Fox lançou clipes do filme no YouTube e uma promoção para fãs assistirem ao filme com o autor e o elenco, o que ocorreu em Miami, Cleveland, Nashiville e Dallas. 
A partir da premissa de Adorno (2015), apresentada no capítulo 3 desta tese, de que existe uma reprodução de elementos iguais e de que esta satisfaz o espectador, e amparada nas discussões feitas por Martín-Barbero (2013) e García Canclini (2008b) de que os atores envolvidos perdem a autonomia para tomar decisões e são levados a produzir em função de um mercado consumidor, apresento, no quadro a seguir algumas informações sobre os sete filmes visualizados pelos sujeitos desta pesquisa: 


\begin{tabular}{|c|c|c|c|c|c|c|c|}
\hline Filme & Gênero & Direção & Atriz principal & Ator principal & Roteiro & $\begin{array}{l}\text { Tempo de } \\
\text { duração }\end{array}$ & $\begin{array}{l}\text { Faz parte de } \\
\text { uma série? }\end{array}$ \\
\hline A culpa é das estrelas & Drama & Josh Boone & $\begin{array}{c}\text { Shailene } \\
\text { Woodley (Hazel) }\end{array}$ & $\begin{array}{l}\text { Ansel Elgort } \\
\text { (Gus) }\end{array}$ & $\begin{array}{l}\text { Baseado no Best- } \\
\text { Seller de John Green }\end{array}$ & $125 \mathrm{~min}$ & Não \\
\hline Malévola & $\begin{array}{l}\text { Fantasia/ } \\
\text { Ação }\end{array}$ & $\begin{array}{l}\text { Robert } \\
\text { Stromberg }\end{array}$ & $\begin{array}{l}\text { Elle Fanning } \\
\text { (Aurora) } \\
\text { Angelina Jolie } \\
\text { (Malévola) }\end{array}$ & $\begin{array}{l}\text { Sharlto Copley } \\
\text { (Rei Stefan) }\end{array}$ & $\begin{array}{l}\text { Paráfrase do conto de } \\
\text { fadas A Bela } \\
\text { Adormecida }\end{array}$ & $96 \mathrm{~min}$ & Não \\
\hline $\begin{array}{l}X \text {-Men: dias de um } \\
\text { futuro esquecido }\end{array}$ & $\begin{array}{c}\text { Fiçãão } \\
\text { científica/ } \\
\text { Suspense } \\
\end{array}$ & Bryan Singer & $\begin{array}{l}\text { Jenifer Lawrence } \\
\text { (Mística) }\end{array}$ & $\begin{array}{l}\text { Hugh Jackman } \\
\text { (Logan) }\end{array}$ & $\begin{array}{c}\text { Baseado nos super- } \\
\text { heróis da Marvel } \\
\text { Comics }\end{array}$ & $131 \mathrm{~min}$ & Sim \\
\hline $\begin{array}{l}\text { Jogos vorazes: a } \\
\text { esperança - parte } 1\end{array}$ & $\begin{array}{l}\text { Fantasia/ } \\
\text { Fiçãão } \\
\text { Científica }\end{array}$ & $\begin{array}{l}\text { Francis } \\
\text { Lawrence }\end{array}$ & $\begin{array}{c}\text { Jenifer Lawrence } \\
\text { (Katniss } \\
\text { Everdeen) }\end{array}$ & $\begin{array}{c}\text { Josh } \\
\text { Hutcherson } \\
\text { (Peeta Mellark) }\end{array}$ & $\begin{array}{l}\text { Adaptação do livro de } \\
\text { Suzanne Collins }\end{array}$ & $123 \mathrm{~min}$ & Sim \\
\hline $\begin{array}{l}\text { As crônicas de Nárnia: } \\
\text { o Leão, a Feiticeira e } \\
\text { o Guarda-Roupa }\end{array}$ & $\begin{array}{l}\text { Fantasia/ } \\
\text { Aventura }\end{array}$ & $\begin{array}{l}\text { Andrew } \\
\text { Adamson }\end{array}$ & $\begin{array}{l}\text { Anna Popplewell } \\
\text { (Susana) } \\
\text { Goergie Henley } \\
\text { (Lúcia) }\end{array}$ & $\begin{array}{c}\text { Skandar } \\
\text { Keynes } \\
\text { (Edmundo) } \\
\text { William } \\
\text { Moseley } \\
\text { (Pedro) }\end{array}$ & $\begin{array}{c}\text { Baseado nos } \\
\text { romances de L.S. } \\
\text { Lewis }\end{array}$ & $150 \mathrm{~min}$ & Sim \\
\hline $\begin{array}{l}\text { João e Maria: } \\
\text { caçadores de bruxas }\end{array}$ & $\begin{array}{l}\text { Fantasia/ } \\
\text { Ação }\end{array}$ & Tommy Wirkola & $\begin{array}{l}\text { Gemma Arteton } \\
\text { (Maria) }\end{array}$ & $\begin{array}{c}\text { Jeremy Renner } \\
\text { (João) }\end{array}$ & $\begin{array}{l}\text { Paráfrase do conto de } \\
\text { fadas João e Maria }\end{array}$ & $98 \mathrm{~min}$ & Sim \\
\hline $\begin{array}{l}\text { Jurassic World: o } \\
\text { mundo dos } \\
\text { dinossauros }\end{array}$ & $\begin{array}{l}\text { Fiçção } \\
\text { científica/ } \\
\text { Suspense }\end{array}$ & Colin Trevorrow & $\begin{array}{l}\text { Bryce Dallas } \\
\text { Howard (Claire } \\
\text { Dearing) }\end{array}$ & $\begin{array}{l}\text { Chris Pratt } \\
\text { (Owen Grady) }\end{array}$ & Roteiro original & $124 \mathrm{~min}$ & Sim. \\
\hline
\end{tabular}

Quadro 4 - Ficha técnica dos filmes vistos pelos jovens nas oficinas

Fonte: Elaboração própria a partir de dados da Ancine e de sites especializados em cinema. 
Dos sete filmes vistos, apenas um é classificado como drama, os demais ficam entre fantasia e ficção científica, o que parece atender ao gosto dos jovens: filmes que podem fazer o espectador sair da sua rotina diária e levá-lo a imaginar a fantasia como possibilidade de vida. As narrativas audiovisuais tornam-se momentos de supressão temporária da realidade ou, nas palavras de Eco (1970, p. 247), ao mencionar a identificação dos homens com a imagem do Superman, é o momento em que "as exigências de poder que o cidadão nutre e não pode satisfazer" são realizadas através da ficção. É possível afirmar que os espectadores colocam-se no lugar de determinadas personagens e se realizam através delas.

As falas de alguns participantes da pesquisa, ao assistirem aos filmes, confirmam essa possibilidade de identificação com situações que são fantasiosas ou estão longe do cotidiano deles. A aluna que se autoidentificou como Malévola ${ }^{29}$, ao se referir a uma cena do filme de mesmo nome, na qual o pai ignora a personagem Aurora, afirma "Nossa, eu matava este cara, na moral!" Essa mesma jovem afirmou, durante a visualização de outra narrativa, que neste tipo de filme ninguém morre, ou seja, eles sabem que não existe compromisso com a realidade e parecem se sentir confortáveis com isso, ao mesmo tempo em que se colocam no papel de um dos personagens. Segundo Nogueira (2010, p. 27), nos filmes classificados como fantásticos: "as relações de causa-efeito como as conhecemos são constantemente desafiadas: seja na mente das personagens seja na mais reconhecível banalidade, tudo acaba por, a certo momento e em certas condições, se tornar possível." A jovem já compreendeu esse mecanismo e sabe que as possibilidades em filmes de fantasia são diversas. A ficção científica segue basicamente a mesma lógica, mas o que está em jogo é a especulação sobre outros mundos ou o futuro da humanidade numa aproximação da fantasia com a realidade, ou seja, a verossimilhança ${ }^{30}$.

Para Nogueira (2010), a classificação por gêneros no audiovisual cumpre papel parecido com os gêneros na literatura ou nas artes, que é o de balizar o espectador sobre aquilo que ele irá encontrar. Ao responder o que é um gênero, o autor afirma:

Um género será uma categoria classificativa que permite estabelecer relações de semelhança ou identidade entre as diversas obras. Desse modo, será possível, seguindo o raciocínio genérico, encontrar a génese comum de um conjunto de

\footnotetext{
${ }^{29}$ Os nomes dos participantes da pesquisa são fictícios e foram mudados para preservá-los, eles mesmos escolheram seus nomes, neste capítulo, mais a frente, será explicado como se deu esta escolha. .

${ }^{30}$ Verossimilhança é um termo que vem da crítica literária e que está relacionado à criação de um ambiente ficcional, mas que tem uma lógica e coerência que o fazem parecer plausível.
} 
obras, procurando nelas os sinais de uma partilha morfológica e ontológica assim, através da ínfima comunhão de determinadas características por parte de um conjunto de obras, poderemos sempre proceder a genealogia mais remota das mesmas, o que haverá de permitir compreender melhor o seu processo criativo e efectuar a arqueologia das ideias fundamentais que veiculam ou das situações que retratam. (NOGUEIRA, 2010, p. 4).

Para o autor, a classificação por gêneros no cinema cumpre funções em pelo menos seis contextos: produção, consumo, criação, crítica, análise e divulgação. Ao analisar os contextos propostos por Nogueira (2010), fica evidenciado que a função principal da classificação por gêneros no audiovisual é a padronização na fórmula de fazer filmes, o que facilita a identificação do espectador, que sabe o tipo de repertório a esperar.

Ainda em relação à classificação dos filmes por gênero, García Canclini (2008b) adverte que nas videolocadoras, por exemplo, a insatisfação dos usuários não é pela falta de diversidade de filmes, mas por não ter cópias suficientes do último lançamento. Segundo o autor:

As locadoras principalmente blockbusters, ordenam os filmes por "gêneros": comédia, drama, terror, erótico, infantis. Todos são dos Estados Unidos e falado em inglês, enquanto a parte restante, minoritária, de produções europeias, asiáticas e latino-americanas, é agrupada por "filmes estrangeiros". (García Canclini, 2008b, p. 26-27).

Dos filmes vistos, apenas Jurassic World: o mundo dos dinossauros tem roteiro original, os outros seis filmes são baseados ou adaptados de outras obras já existentes (livros, estórias em quadrinhos ou contos de fadas). Cinco dos sete filmes são continuidade ou tiveram continuidade em outra narrativa fílmica, são as chamadas cinesséries ou franquias, o que aponta para a possibilidade de criação de um público para a série de filmes, ou seja, o espectador possivelmente irá novamente ao cinema para ver a continuação do filme ou o assistirá na TV ou em DVD, quando estiver disponível.

Além dessas questões técnicas, duração do filme, as cinesséries, os gêneros e outros, as narrativas que compuseram as oficinas de visualização de filmes apresentavam enredos fáceis e bastante padronizados, posto que seguiam a uma estrutura básica que consistia na apresentação das personagens e cenário (ambientação), passavam, em seguida para apresentação do conflito e terminavam com o desfecho dos fatos. O quadro a seguir traz um resumo das narrativas: 


\begin{tabular}{|c|c|c|c|}
\hline Filme & Ambientação & Conflito & Desfecho \\
\hline A culpa é das estrelas & Ocorre nos EUA nos dias atuais. & $\begin{array}{l}\text { Casal com câncer se conhece em um grupo de } \\
\text { apoio e vive um romance. }\end{array}$ & $\begin{array}{l}\text { Um deles morre, mas consegue deixar } \\
\text { a outra com esperanças para } \\
\text { continuar a viver. }\end{array}$ \\
\hline Malévola & $\begin{array}{l}\text { Em uma floresta, em um tempo } \\
\text { distante. }\end{array}$ & $\begin{array}{l}\text { Malévola se apaixona por Stefan, mas ele se } \\
\text { casa com a princesa e ela amaldiçoa Aurora, filha } \\
\text { dele. }\end{array}$ & $\begin{array}{l}\text { Malévola e Aurora ficam amigas e o rei } \\
\text { morre. }\end{array}$ \\
\hline $\begin{array}{l}X \text {-Men: dias de um } \\
\text { futuro esquecido }\end{array}$ & $\begin{array}{l}\text { Começa no futuro com uma luta } \\
\text { entre X-Men e Sentinelas. }\end{array}$ & $\begin{array}{l}\text { Logan volta a } 1973 \text { para impedir que Mística mate } \\
\text { o criador dos Sentinelas. Para resolver o conflito } \\
\text { do futuro é preciso resolver simultaneamente o do } \\
\text { passado. }\end{array}$ & $\begin{array}{l}\text { Os X-Men conseguem vencer os } \\
\text { Sentinelas. }\end{array}$ \\
\hline $\begin{array}{l}\text { Jogos vorazes: a } \\
\text { esperança - parte } 1\end{array}$ & $\begin{array}{l}\text { É ambientado em um país } \\
\text { fictício e Katniss luta contra o } \\
\text { presidente ao lado dos rebeldes. }\end{array}$ & $\begin{array}{l}\text { O Distrito } 12 \text { foi destruído e Katniss é resgatada } \\
\text { pelos rebeldes do Distrito } 13 \text {. Ela tenta salvar seu } \\
\text { namorado Peeta, que está como refém do } \\
\text { presidente. }\end{array}$ & $\begin{array}{l}\text { Katniss consegue trazer Peeta para o } \\
\text { Distrito } 13 .\end{array}$ \\
\hline $\begin{array}{l}\text { As crônicas de Nárnia: } \\
\text { o Leão, a Feiticeira e } \\
\text { o Guarda-Roupa }\end{array}$ & $\begin{array}{l}\text { Durante os bombardeios da } \\
\text { Segunda Guerra Mundial de } \\
\text { Londres, quatro irmãos são } \\
\text { enviados para uma casa de } \\
\text { campo onde eles estarão } \\
\text { seguros. }\end{array}$ & $\begin{array}{l}\text { Os irmãos descobrem uma passagem secreta } \\
\text { dentro do guarda-roupa da casa de campo que os } \\
\text { leva à Nárnia. Lá eles devem salvar a todos da } \\
\text { Feiticeira. }\end{array}$ & $\begin{array}{l}\text { Com ajuda de Aslan, os irmãos salvam } \\
\text { Nárnia da Feiticeira e são coroados } \\
\text { príncipes. }\end{array}$ \\
\hline $\begin{array}{l}\text { João e Maria: } \\
\text { caçadores de bruxas }\end{array}$ & $\begin{array}{l}\text { Na idade média, em um } \\
\text { lugarejo. }\end{array}$ & $\begin{array}{l}\text { João e Maria precisam salvar uma cidade onde } \\
\text { as bruxas estão matando todas as crianças. }\end{array}$ & $\begin{array}{l}\text { Eles matam a bruxa negra e deixam a } \\
\text { cidade livre. }\end{array}$ \\
\hline $\begin{array}{l}\text { Jurassic World: o } \\
\text { mundo dos } \\
\text { dinossauros }\end{array}$ & A ilha fictícia Nublar. & $\begin{array}{l}\text { Os sobrinhos de Claire vão passear no Jurassic } \\
\text { World, mas algo acontece com um novo } \\
\text { dinossauro que deixa todo o parque sob ameaça. }\end{array}$ & $\begin{array}{l}\text { Claire e Owen conseguem salvar os } \\
\text { sobrinhos dela e todo o parque. }\end{array}$ \\
\hline
\end{tabular}

Quadro 5 - Construção narrativa dos filmes vistos pelos jovens nas oficinas

Fonte: Elaboração própria partir de dados da Ancine e de sites especializados em cinema. 
Dos sete filmes, o único que não tem uma narrativa linear é $X$-Men: dias de um futuro esquecido, pois neste o personagem vivido por Hugh Jackman (Logan/ Wolverine) volta no tempo para impedir que Mística (Jenifer Lawrence) seja capturada por Bolivar Trask (Peter Dinklage). Ao voltar ao passado, Logan encontra o Professor Xavier (James McAvoy), Magneto (Michael Fassbender) e outros mutantes ainda jovens. Há, em vários momentos da narrativa, passagens de tempo e referências a fatos futuros; além disso, o filme já começa com o conflito (a guerra entre mutantes e sentinelas) e há também várias referências a outros filmes da série, o que torna sua narrativa mais complexa e pouco linear. Várias personagens são vividas por dois atores diferentes, um representando a personagem no passado e outro, no futuro. Todos os filmes terminam com um happy end, ou seja, com o conflito resolvido, mesmo aqueles que terão continuação, o que atende a uma convenção na estrutura dos filmes hollywoodianos de grandes bilheterias.

Para checar os interesses pessoais por filmes, dos jovens que participaram desta pesquisa, solicitei a eles que fizessem uma lista dos 10 filmes que eles mais gostaram de assistir. Para essa atividade, não estabeleci nenhuma regra mais específica, poderia ser filme visto em qualquer época da vida deles, de qualquer gênero e sem restrição dos tipos de personagens.

No dia da atividade, 26 participantes estavam presentes e fizeram suas listas. Na lista de 22 deles, constava um mesmo filme: Velozes e furiosos. $\mathrm{O}$ filme mais votado é uma cinessérie que já está no oitavo filme, este último lançado no Brasil em 2015. Como havia uma variação entre as diversas sequências, levei em conta como sendo um único filme. Porém, alguns votaram mais de uma vez, pois escolheram mais de um filme da série, outros indicaram na mesma linha todos os filmes da série (de 1 a 8) e houve, ainda, aqueles que escolheram um filme específico e outros que colocaram apenas o nome do filme sem escolher um em especial. O mesmo ocorreu com outros filmes que têm continuidade, pois, muitas vezes, foram informados com o nome geral sem mencionar qual parte específica da série de filmes o aluno se referia.

A série Velozes e furiosos teve o primeiro filme lançado em 2001 e, praticamente, a cada dois anos uma nova saga é levada a público. As histórias têm sempre muita ação e giram em torno de corridas automobilísticas ilegais, além de assaltos e crimes. Alguns dos filmes tiveram locações fora dos Estados Unidos, com cenas gravadas no Rio de Janeiro e em Tóquio. Vin Diesel é o ator principal da série e está em sete dos oito filmes lançados. Segundo o site Papo de cinema: 
Os seis primeiros filmes arrecadaram mais de US $\$ 2,7$ bilhões nas bilheterias de todo o mundo, e esse impacto junto ao público tem crescido a cada novo lançamento, aumentando as expectativas e os valores envolvidos, deixando tudo ainda mais espetacular e impressionante. Muita ação, adrenalina à flor da pele, carros superpoderosos e astros jovens e bonitos: uma combinação que não tinha, mesmo, como dar errado. ${ }^{31}$

Os dados de bilheteria do filme no cinema são realmente impressionantes, a última sequência rendeu, apenas nos três primeiros dias em cartaz após o lançamento mundial, 384 milhões de dólares, sendo que o orçamento do filme foi de 250 milhões, o que significa dizer que em apenas três dias o filme cobriu o orçamento e teve um lucro de mais de 100 milhões de dólares, fora os outros produtos para os quais o lançamento faz estabelecer uma vitrine para vendas posteriores.

Os outros filmes apontados pelos participantes das oficinas seguem o mesmo padrão: grandes bilheterias, filmes que chegam rapidamente à TV, muitas propagandas que costumam começar meses antes do lançamento, linguagem fácil e estrutura narrativa linear, sendo, a maioria deles, cinesséries.

Nos quadros a seguir, apresento os filmes mais indicados na preferência dos meninos e das meninas, fiz esta divisão por gênero, pois 17 meninos fizeram suas listas e apenas 9 meninas participaram desta etapa da pesquisa, que ocorreu no final da pesquisa de campo, quando eles já haviam visualizado os filmes do projeto. Optei pela divisão por gêneros, pois constatei que o número muito menor de meninas poderia interferir no resultado.

No primeiro quadro, com as preferências dos meninos aparecem os filmes que tiveram até 5 votos; 173 filmes foram citados, mas a concentração maior de votos ficou entre os oito primeiros listados. Cito no quadro os anos de lançamentos de todas as sequências dos filmes, quando estes fazem parte de uma série:

\footnotetext{
${ }^{31}$ Disponível em: <http://www.papodecinema.com.br/especiais/saga-velozes-e-furiosos>. Acesso em 29 de maio de 2017.
} 


\begin{tabular}{|c|c|c|}
\hline & Meninos & 173 filmes \\
\hline $1^{0}$ & $\begin{array}{l}\text { Velozes e furiosos (EUA, 2001, 2003, 2006, 2009, 2011, } \\
2013,2015,2017)\end{array}$ & 14 \\
\hline $2^{\circ}$ & Guardiões da galáxia (EUA, 2014, 2017) & 8 \\
\hline $3^{\circ}$ & A era do gelo (EUA, 2002, 2006, 2008, 2009, 2016) & 7 \\
\hline $4^{0}$ & Jurassic Word (EUA, 1993, 1997, 2001, 2015) & 6 \\
\hline $5^{0}$ & $X-M e n(E U A, 2000,2003,2006,2009,2011,2014,2016)$ & 6 \\
\hline $6^{0}$ & Chucky (EUA, 1988, 1990, 1991, 1998, 2004, 2013) & 5 \\
\hline $7^{0}$ & $\begin{array}{l}\text { Harry Potter (Reino Unido/EUA, 2002, 2004, 2005, } 2007, \\
\text { 2010, 2011) }\end{array}$ & 5 \\
\hline $8^{\circ}$ & João e Maria: caçadores de bruxas (2013) & 5 \\
\hline
\end{tabular}

Quadro 6 - Lista de filmes dos meninos ${ }^{32}$

Fonte: Elaboração própria.

Vale notar que, dos 8 filmes mais votados pelos meninos, apenas o último não faz parte de uma série, todos os outros apresentam continuação e são filmes de grandes bilheterias no mundo inteiro. Dos filmes mais votados, 3 foram exibidos durante a pesquisa de campo: Jurassic World (sequência de 2015), $X$ Men (sequência de 2014) e João e Maria: caçadores de bruxas (2013). Destes, o primeiro e o último foram escolhidos pelos jovens para visualização durante a pesquisa de campo, conforme relatado anteriormente, o que confirma o gosto deles por esses filmes.

Para dimensionar o valor de mercado desses filmes, se tivermos como parâmetro os 8 filmes que compõem a saga Harry Potter, por exemplo, o sétimo mais votado entre os meninos e o quinto mais votado pelas meninas (conforme apresento no quadro a seguir), veremos que eles estão entre os 50 filmes de maior bilheteria da história do cinema e, apesar de a história ter sido escrita por uma britânica, todos os filmes foram produzidos pela indústria cinematográfica hollywoodiana, tendo como produtora a Heyday Films e como distribuidora, a Warner Bros. A receita de todos esses filmes foi de quase 8 bilhões de dólares.

\footnotetext{
32 Os nomes dados a cada um das sequências dos filmes são: 1) Velozes e furiosos (2001), Mais velozes e mais furiosos (2003), Velozes e furiosos: desafio em Tóquio (2006), Velozes e furiosos 4 (2009), Velozes e furiosos 5 (2011), Velozes e furiosos 6 (2013), Velozes e furiosos 7 (2015) e Velozes e furiosos 8 (2017); 2) Guardiões da galáxia (2014) e Guardiões da galáxia 2 (2017); 3) A era do gelo (2002), A era do gelo 2 (2006), A era do gelo 3 (2008), A era do gelo 4 (2009) e $A$ era do gelo 5 (2016); 4) Jurassic Park: o parque dos dinossauros (1993), O mundo perdido: Jurassic Park (1997), Jurassic Park 3 (2001) e Jurassic World: o mundo dos dinossauros (2015); 5) X-Men: o filme (2000), X-Men 2 (2003), X-Men: o confronto final (2006), X-Men: origens Wolverine (2009), $X-M e n:$ primeira classe (2011), X-Men: dias de um futuro esquecido (2014), X-Men: apocalipse (2016); 6) Brinquedo assassino (1988), Brinquedo assassino 2 (1990), Brinquedo assassino 3 (1991), A noiva de Chucky (1998), O filho de Chucky (2004), A maldição de Chucky (2013); 7) Harry Potter e a câmara secreta (2002), Harry Potter e o prisioneiro de Azkaban (2004), Harry Potter e o cálice de fogo (2005), Harry Potter e a Ordem da Fênix (2007), Harry Potter e o enigma do príncipe (2009), Harry Potter e as relíquias da morte: parte 1 (2010), Harry Potter e as relíquias da morte: parte 2 (2011).
} 
No quadro seguinte, trago os 8 filmes mais votados pelas meninas, que escolheram 88 filmes diferentes.

\begin{tabular}{|c|l|c|}
\hline & \multicolumn{1}{|c|}{ Meninas } & $\mathbf{1}$ \\
\hline $1^{\circ}$ & $\begin{array}{l}\text { Velozes e furiosos (EUA, 2001, 2003,2006, 2009, 2011, } \\
\text { 2013, 2015, 2017) }\end{array}$ & 8 \\
\hline $2^{\circ}$ & A Bela e a Fera (EUA, 2017) & 6 \\
\hline $3^{\circ}$ & A culpa é das estrelas (EUA, 2014) & 5 \\
\hline $4^{\circ}$ & Malévola (EUA, 2014) & 5 \\
\hline $5^{\circ}$ & $\begin{array}{l}\text { Harry Potter (Reino Unido/EUA, 2002, 2004, 2005, 2007, } \\
\text { 2010, 2011) }\end{array}$ & 4 \\
\hline $6^{\circ}$ & Esquadrão suicida (EUA, 2016) & 3 \\
\hline $7^{\circ}$ & Jurassic Word (EUA, 1993, 1997, 2001, 2015) & 3 \\
\hline $8^{\circ}$ & Alice através do espelho (EUA, 2016) & 2 \\
\hline
\end{tabular}

Quadro 7 - Lista de filmes das meninas

Fonte: Elaboração própria.

Assim como os meninos, o filme mais votado pelas meninas foi Velozes e furiosos, sendo que apenas uma delas não citou este como um de seus 10 favoritos. Além deste, mais dois filmes foram comuns a meninos e meninas: Harry Potter e Jurassic World. Estes também foram os únicos três filmes votados pelas meninas que são cinesséries, os demais não seguem uma sequência. Dos 8 filmes mais votados pelas meninas, três foram visualizados durante a pesquisa de campo: A culpa é das estrelas (2014), Malévola (2014) e Jurassic World (2015).

O resultado desse levantamento confirma a análise feita por García Canclini (2015, p. 249):

A essas condições os estudos realizados em vários países latino-americanos sobre consumo cultural acrescentam a sintonia entre os gostos do público e os estilos de filmes estadunidenses. Os "gêneros" preferidos pelos públicos latinos e latino-americanos são os de ação (thrillers, aventura, espionagem), ou seja, os mais bem cultivados por Hollywood. Essa preferência é maior entre homens das gerações adultas, enquanto as mulheres mostram inclinação pelos temas "sentimentais" e "familiares". Essas tendências acentuam-se no crescente público juvenil, cujo gosto pelos filmes de ação aparece mais acentuado e uniforme entre os sexos.

Em relação ao filme Alice através do espelho (2016), no ano letivo de 2016, em um dos projetos desenvolvidos pela escola, foi feita a leitura do livro de mesmo nome do escritor britânico Lewis Carroll (1832-1898), que foi adaptado para o cinema, e este projeto escolar culminou na ida dos alunos ao cinema para assistir ao filme adaptado do livro. A pesquisa com os filmes preferidos dos jovens foi feita semanas depois desta ida ao cinema. 
O filme A Bela e a Fera, escolhido por 6 das 9 alunas, é a versão nova produzida pela Disney e, à época da pesquisa, ainda não tinha sido lançada nos cinemas. A escolha por esse filme confirma que mesmo sem ir ao cinema com frequência, muitos jovens têm acesso aos filmes por outras plataformas, até mesmo através das cópias piratas ${ }^{33}$ de filmes. Ao tratar de filmes vistos por crianças, a pesquisa de Sacramento (2008, p. 53) aponta esse dado e, segundo o autor:

No contato direto com as crianças, logo percebemos que, apesar de não freqüentarem salas de exibição, o acesso delas a filmes é extremamente amplo quantitativamente, vale dizer - inclusive a títulos produzidos para o público adulto. Por meio de aparelhos de DVD e o acesso quase irrestrito a cópias, na maioria das vezes não autorizadas, elas têm acesso a um grande volume de títulos e, não raro, acompanham o ritmo dos lançamentos em grande circuito.

Nesse sentido, além da TV, os jovens participantes desta pesquisa contam com a opção de assistirem a seus filmes preferidos através do DVD ou via internet, muitas vezes, usando cópias ilegais, mesmo antes de esses filmes chegarem às salas de cinema.

Todos os filmes mais votados tanto pelos meninos quanto pelas meninas são estadunidenses, e apenas Harry Potter tem coprodução do Reino Unido, conforme já mencionado.

Se levarmos em conta os 261 filmes citados, apenas um jovem citou um filme brasileiro, Tropa de elite, dirigido por José Padilha, lançado em 2007 e premiado no festival de Berlim. O filme foi exibido em 321 salas de cinema no Brasil e teve um público de 2.241.295 pagantes (Ancine, 2017). A sequência deste filme, Tropa de elite 2 (2010), foi a indicação do Brasil para concorrer ao Oscar de Melhor Filme Estrangeiro, sendo este o filme mais visto da história do cinema brasileiro, com 11.146 .723 pagantes, distribuído em 763 salas.

A partir desses dados levantados sobre a preferência dos jovens participantes da pesquisa, retomo a pesquisa de Sacramento (2008) que solicitou às crianças de sua pesquisa uma lista de filmes que tinham visto nos últimos tempos, apontando aqueles de que mais gostaram. O autor categorizou a lista das respostas como "mais do mesmo":

[...] como uma possibilidade de descrição da relação dessas crianças com produtos audiovisuais. Pode-se dizer que a produção a que elas têm acesso seja ela realizada para tevê ou para cinema, segue um padrão narrativo mais ou menos recorrente: temática simples, montagem linear, personagens padronizados

${ }^{33}$ Cópias piratas ou não autorizadas são aquelas gravadas ilegalmente, sem autorização do distribuidor e, muitas vezes, sem a mesma qualidade da original. Essas cópias são vendidas geralmente nos centros comerciais, facilmente encontradas em camelôs e lojas populares não apenas de grandes cidades, mas em vários locais espalhados pelo país, desde rodoviárias até shoppings. 
e pouco complexos, conflitos mais ou menos superficiais que acabam bem resolvidos, no final da trama. Em sua maioria, produções altamente comerciais, realizadas nos Estados Unidos, destinadas ao grande público. (Sacramento, 2008, p. 62).

Durante a pesquisa, pude perceber o quanto a padronização estética e narrativa dos filmes vistos pelos jovens cotidianamente pode inferir diretamente na criatividade deles. Logo no início da pesquisa, depois da visualização do filme A culpa é das estrelas, pedi que se colocassem no lugar do criador do filme e preenchessem uma ficha fazendo as mudanças do filme que eles achavam necessárias. A ficha consta no Apêndice $F$ deste trabalho e traz a seguinte orientação:

\begin{abstract}
Após assistir ao filme: A culpa é das estrelas e conhecer Hazel e Agustus, as personagens principais, se você fosse o autor do roteiro do filme, como você caracterizaria as personagens principais (seus gostos/ suas características físicas/ em que cidade morariam?/ onde se conheceriam?/ idade/ para onde iriam viajar?/ o que seria o empecilho para eles viajarem?/ quem eles gostariam de conhecer?/ como o ídolo deles os trataria?/ como seria o desfecho do filme?).
\end{abstract}

Participaram dessa dinâmica 27 jovens e apenas dois apontaram mudanças significativas nas características das personagens ou na estrutura do filme. Os demais praticamente reproduziram o filme que viram e, quando fizeram alguma mudança, esta ocorreu frequentemente no desfecho do filme, deixando o final da narrativa menos triste o que indica que os filmes de ficção podem ser, conforme supunha Adorno (2015), uma válvula de escape ou uma fuga da realidade, o que faz com que narrativas fantasiosas com finais felizes obtenham mais sucesso junto ao público do que os dramas com finais trágicos.

Pude notar, também, que as cidades escolhidas pelos alunos para o desenrolar da narrativa e para servir de cenário para a viagem das personagens foram cidades estadunidenses, como: Los Angeles, Nova lorque, São Francisco, além disso, o lugar escolhido para a viagem das personagens por grande parte dos jovens foi a Disney, provavelmente por ser uma influência midiática, ou seja, são lugares que eles não conhecem, mas têm contato a partir dos filmes e material audiovisual a que assistem. Apareceram outras referências a lugares, como China, Dubai, Japão, Rio de Janeiro, Holanda (para onde as personagens principais viajaram no filme visto).

Também me chamou atenção as modificações na estrutura narrativa feita por um dos alunos, pois diferente dos demais, ele mudou inclusive o argumento central, que é a doença das personagens principais. Porém, ao ler a atividade dele, percebi que ele reescreveu as mudanças a partir de outra saga de muito sucesso, e fiz logo o seguinte comentário: "O filme que o Edward inventou já 
existe, é Crepúsculo", o aluno logo sorriu concordando, o que comprova o quanto esses filmes de grandes bilheterias estão no cotidiano desses jovens. Eu disse isso, pois o roteiro apresentado por ele mencionava vampiros e imortalidade, mote central da saga a qual me referi.

Crepúsculo (Catherine Hardwiche, 2008) é um filme que, segundo dados da Ancine (2009), foi distribuído para 403 salas brasileiras de cinema, o que é um número considerado alto para aquele período, visto que segundo o relatório anual de distribuição em salas de 2008 , os filmes com maiores números de distribuição foram aqueles com um pouco mais de 500 salas de projeção, sendo que aquele com mais fitas distribuídas foi Madagascar 2 (Tom McGrath e Eric Darnell, 2008), com 578 salas. Crepúsculo é uma história de vampiros com temática jovem, segue os mesmos padrões dos filmes de grandes bilheterias vistos pelos jovens durante o período de realização da pesquisa, é o primeiro filme de uma cinessérie, baseado nos livros de Stephenie Meyer e, assim como a saga de Harry Potter, fez enorme sucesso no mundo inteiro. A sinopse do filme, segundo o site Adoro Cinema, é:

\begin{abstract}
Isabella Swan (Kristen Stewart) e seu pai, Charlie (Billy Burke), mudaram-se recentemente. No novo colégio ela logo conhece Edward Cullen (Robert Pattinson), um jovem admirado por todas as garotas locais e que mantém uma aura de mistério em torno de si. Eles aos poucos se apaixonam, mas Edward sabe que isto põe a vida de Isabella em risco. ${ }^{34}$
\end{abstract}

Ainda com relação a um modelo pré-determinado de estrutura narrativa, após a visualização de alguns filmes, resolvi repetir a experiência da atividade feita com o filme A culpa é das estrelas, em que pedi a eles para recriarem o cenário e características centrais da narrativa, desta vez com um dos filmes escolhidos por eles: João e Maria: caçadores de bruxas (o modelo da atividade consta no Apêndice $H$ ). Apesar de um envolvimento com outras atividades da pesquisa em que pudemos discutir sobre a padronização dos filmes, o resultado foi muito parecido ao da primeira atividade, ou seja, poucas mudanças nos roteiros recriados, o que evidencia a necessidade de conhecerem outras narrativas audiovisuais, diferentes das que estão acostumados a assistir.

Nessa atividade, ainda foi possível discutir com os jovens que os roteiristas do filme, assim como em Malévola, usaram um conto de fadas infantil bastante conhecido e puderam transformar a narrativa em um filme de ação, tudo isso para incentivar a recriação deles a partir dos elementos do filme, porém, os resultados não foram diferentes.

\footnotetext{
${ }^{34}$ Disponível em: <http://www.adorocinema.com/filmes/filme-131377/>. Acesso em: 31 maio 2017.
} 
Essa atividade foi desenvolvida por 35 participantes, a resposta de uma das jovens à última questão que os orienta para escreverem a sinopse do filme que eles criariam, ilustra bem a posição deles em não fazer mudanças significativas no roteiro. Ela escreveu: "Eu não tenho imaginação, mas gostaria de fazer tipo o mesmo filme, porém colocaria um boy para a Maria, coitada." (Lince Negra). A resposta da aluna nos remete a Adorno (2015, p. 16), ao afirmar que:

É uma tensão tão automática que não há sequer necessidade de ser atualizado a cada caso para que reprima a imaginação. Aquele que se mostra de tal forma absorvido pelo universo do filme - pelos gestos, imagens, palavras - a ponto de não ser capaz de lhe acrescentar aquilo que Ihe tornaria um universo, não estará, necessariamente por isso, no ato da exibição, ocupado com os efeitos particulares da fita. Os outros filmes e produtos culturais, que necessariamente deve conhecer, tornam-Ihe tão familiares as provas de atenção requeridas que estas se automatizam. A violência da sociedade cultural opera nos homens de uma vez por todas.

Nesse sentido, é possível inferir, a partir da resposta da aluna, que o filme atingiu os objetivos, ou seja, os espectadores gostaram do que viram, e que alguma mudança não seria para agradar ao espectador, mas sim a um das personagens da narrativa.

A partir desses exemplos é possível entender que existe, portanto, uma impermeabilidade nos filmes que são produzidos, principalmente pela indústria cinematográfica hollywoodiana, que virou referência de grande negócio para o cinema mundial com grandes bilheterias e narrativa fácil de ser digerida. Segundo Adorno (2015, p. 9):

Os clichês seriam causados pelas necessidades dos consumidores: por isso seriam aceitos sem oposição. Na realidade, é por causa desse círculo de manipulações e necessidades derivadas que a unidade do sistema torna-se cada vez mais impermeável.

O clichê passa por narrativas muito parecidas, mas passa também pela apresentação de imagens que deixará o espectador com a sensação de conforto, pois novidades em excesso podem assustá-lo e causar estranhamento. O cinema vira, portanto, um "museu de grandes novidades" 35 , e quando uma fórmula dá certo, pode ser repetida à exaustão. Ao apresentar para os participantes da pesquisa a capa do filme Jogos vorazes: a esperança - parte 1, um deles, ao perceber que a atriz que interpretava a personagem principal era a Jennifer Lawrence, a mesma que fez a personagem Mística no filme $X$-Men: dias de um futuro esquecido, filme que tínhamos visto anteriormente, fez o seguinte

\footnotetext{
${ }^{35}$ Referência à letra da música "O tempo não para", composta por Cazuza em 1988 e veiculada no LP de mesmo nome.
} 
comentário: "Eles não trocam? Estão usando a mesma atriz de novo?" (HomemAranha).

A observação do jovem pode nos levar à discussão feita por Adorno (2015, p. 68) de que "cada filme é a apresentação do filme seguinte, que promete reunir outra vez a mesma dupla sob o mesmo céu exótico: quem chega atrasado fica sem saber se assiste ao 'em breve neste cinema' ou ao filme propriamente dito." Ao mesmo tempo, essa fala é um indício de que, apesar de toda a estrutura forte e poderosa dos filmes hollywoodianos, que nos faz pensar que só eles sabem produzir filmes, existem brechas, conforme nos apresenta Martín-Barbero (2013) e estas podem nos fazer rever determinados padrões e questioná-los. Para o autor, não podemos olhar a indústria cultural a partir de um "facilismo maniqueísta", pois "nem toda assimilação do hegemônico pelo subalterno é signo de submissão, assim como a mera recusa não o é de resistência" (p. 114).

Dessa forma, é possível dizer que em alguns momentos, os próprios jovens, sujeitos desta pesquisa, conseguem perceber a padronização nos filmes que viram e são capazes de questionar essas padronizações, mesmo que estas causem conforto.

Fica evidente que os jovens participantes da pesquisa não propõem mudanças nas narrativas, pois os filmes vistos atendem ao seu gosto e, por isso, devem continuar como estão, ou seja, não há necessidade de atualização, sendo a repetição de elementos confortável ou, ainda, nas palavras de Adorno (2015, p. 17): “Infalivelmente, cada manifestação particular da indústria cultural reproduz os homens como aquilo que já foi produzido por toda a indústria cultural." Mas ainda assim, em momentos esporádicos, eles questionam alguns elementos vistos nas narrativas, o que nos dá elementos para discutir a formação do gosto dos sujeitos desta pesquisa.

\section{2 \\ Formação do gosto}

Conforme discutido na seção anterior, há uma padronização estética das narrativas vistas pelos participantes desta pesquisa. Isso tem uma relação direta com 0 acesso que estes têm a essas narrativas, em sua grande parte estadunidenses. Na perspectiva de incentivar a circulação de conteúdos audiovisuais produzidos no Brasil, foram criadas duas leis importantes que podem contribuir para o acesso a materiais audiovisuais de cunho nacional e, 
em um segundo momento, colaborar para a formação do gosto do público brasileiro. São elas: a lei no 12.485/11, que trata da circulação de conteúdo audiovisual produzido no Brasil nos canais de TV pagos e a lei oㅜ 13.006/14, que trata da exibição de filmes de produção nacional nas escolas de educação básica.

A lei no 12.485 entrou em vigor em 12 de setembro de 2011 e ficou conhecida como a Lei de Cotas de Tela. Ela regulamentou o serviço de TV por assinatura no Brasil, antes dispersa em diferentes comandos legais. Essa lei estabelece a veiculação de 3 h30 semanais de programação de conteúdos brasileiros nos canais de espaço qualificado ${ }^{36}$ e, também, determina que todos os pacotes ofertados ao assinante constem de canais brasileiros, numa proporção de 3 por 1, ou seja, a cada três canais de espaço qualificado, pelo menos um deve ser de programadora brasileira.

A defesa da Ancine à lei de cotas caminha na direção de uma concorrência mais justa entre filmes estrangeiros e nacionais, visto que grande parte da cinematografia brasileira não tem grande sucesso de bilheteria e para cumprir os gastos de produção, dependem da venda do produto para a TV. Como visto anteriormente, vários filmes estadunidenses têm enorme lucro apenas com bilheteria, o que contribui para que, em muitos casos, sejam vendidos mais baratos, ou, ainda, são feitos pacotes promocionais e o canal de TV compra 30 filmes, por exemplo, mas só paga pela metade deles, levando os outros de brinde, pois já obtiveram lucro nas salas de cinema. Sendo assim, as cotas buscam compensar essa concorrência, além de contribuir para a divulgação da cultura local. De acordo com o documento da Ancine ${ }^{37}$ :

A política de obrigação de veiculação de conteúdos nacionais não se apoia somente em questões econômicas, mas também em aspectos culturais. Cotas mínimas para conteúdos nacionais geram diversidade nos mercados audiovisuais e são instrumentos legítimos reconhecidos pela comunidade internacional, por meio de Convenção sobre a Proteção e Promoção da Diversidade das Expressões Culturais, assinado em Paris, em 20 de outubro de 2005 por quase todos os países do mundo - exceto EUA e Israel. (ANCINE, 2017, s/pág.).

García Canclini (2015) alerta que a chamada globalização, inclusive dos meios de comunicação, ampliou as desigualdades sociais: "em meio a tantos intercâmbios ou comunicações mundializadas e simultâneas, muitas localidades e regiões sofrem desglobalização" (p. 251), ou seja, enfrentam uma política de isolamento, o que também compromete a diversidade cultural, pois não têm

\footnotetext{
${ }^{36}$ Espaços qualificados são aqueles que exibem predominantemente filmes, séries, animação e documentário.

${ }^{37}$ Disponível em: <https://www.ancine.gov.br/pt-br/faq-lei-da-tv-paga>. Acesso em: 19 jun. 2017.
} 
forças para se inserir no mercado global, muitas vezes, nem como consumidores e ficam restritas ao consumo da produção local de suportes culturais. Por outro lado, segundo o autor, os Estados Unidos dominam o mercado do audiovisual, instaurando um padrão estético. Para ele, mesmo com a posição dos mecanismos internacionais (OMC, Unesco e outros), que defendem a projeção das indústrias culturais nacionais, os Estados Unidos empreendem uma campanha de desqualificação da diversidade cultural, colocando-se contrários às políticas de cotas para conteúdos nacionais, visto que a indústria cultural do país seria a grande prejudicada. Atualmente, segundo García Canclini (2015, p. 247) "96\% dos filmes são administrados por 13 companhias", todas elas estadunidenses. Dessa forma, apostar nesta política de cotas é também colocarse de maneira incisiva contra os oligopólios da indústria cultural, investindo na diversidade e acreditar que "Nem tudo é padronização" (García Canclini, 2008, p. 54). Ainda de acordo com este autor:

Em nenhum lugar, essa conversão de nações numerosas, com alta produção artística, em expressões menores é tão chocante quanto nos Estados Unidos. Enquanto esse país exige absoluta liberação dos mercados, sem cotas de exibição e sem nenhuma política de proteção para os filmes nacionais, o sistema de distribuição e exibição estadunidense combina vários fatores para assegurar um rígido favoritismo dos filmes do seu país. (García Canclini, 2015, p. 246).

Certamente a lei de cotas não garante que filmes brasileiros sejam mais vistos e aprovados pelo espectador de canal fechado, mas impulsiona a produção de audiovisual no Brasil e visibiliza essas produções, garantindo maior acesso a elas. Nesse sentido, pode ser um caminho para o aumento de produção e para que mais produtos nacionais sejam exibidos na programação, levando à ampliação do público.

A lei $n^{\circ}$ 13.006/14, aprovada no dia 26 de junho de 2014, acrescenta $\S 8^{\circ}$ ao artigo 26 da LDB, que estabelece as diretrizes e bases da educação nacional. Segundo este parágrafo, "a exibição de filmes de produção nacional constituirá componente curricular complementar integrado à proposta pedagógica da escola, sendo a sua exibição obrigatória por, no mínimo duas horas mensais."

Entendo que esta lei tem como objetivo, mais do que divulgar o cinema nacional ao público infantil e jovem que frequenta as escolas brasileiras, apresentar para este público filmes aos quais eles não teriam acesso em seu cotidiano, pois muitas vezes, ficam restritos a poucas salas de cinema ou aos canais fechados de TV. Segundo Fonseca (2016, p. 38):

Os projetos atuais que levam cinema para a escola buscam a formação de pensamento crítico, criação de repertório, formação de gosto e produção, voltados para a autoria e criticidade dos alunos que não são apenas espectadores dos 
filmes antes escolhidos por outrem, mas curadores e organizadores de cineclubes nas escolas, roteiristas de vídeos, criadores de animações, entre outros.

Acredito que a lei sozinha, sem a formação de professores para o audiovisual, infraestrutura física e material (salas adequadas com material para projeção, além do acesso às obras brasileiras, que muitas vezes, não são disponibilizadas em DVD) e espaço para discussão dos filmes a serem vistos não altera em nada ou quase nada o cenário atual em que, como já apresentado neste trabalho, muitas escolas não dispõem nem mesmo de um espaço e material para projeção audiovisual. Porém, o fato de a lei ter sido aprovada abre espaço para discutirmos todas essas questões levantadas e faz com que os agentes ligados à educação e ao cinema possam pensar em caminhos e possibilidades deste vir a ser um diferencial na formação dos alunos. Nas palavras de Fresquet e Migliorin (2015, p. 9):

A lei cria a possibilidade da escola garantir o acesso a toda criança - e famílias escolarizada ao cinema, mas, mais do que isso, a possibilidade de acesso a sistemas de expressão e signos, blocos de ideias e estéticas marginalizadas pelo mercado e pelo sistema oligopolista de exibição.

Acredito que a aprovação da lei seja uma oportunidade de tratar da literacia fílmica nas escolas brasileiras e ampliar o olhar de meninas e meninos que não têm acesso ao cinema cotidianamente a filmes que não são encontrados com tanta facilidade, quanto os filmes visualizados durante esta pesquisa. Mas também tenho consciência de que a lei só faz sentido se possibilitar o diálogo e o surgimento de propostas inovadoras e que sejam capazes de unir criticidade, autoria e autonomia, conforme defendido por Fonseca (2016).

Fresquet e Migliorin (2015, p. 9) resumem bem o papel desta lei, ao tratar do jogo presente na relação entre cinema e escola:

O cinema na escola opera imediatamente a transmutação de todos em espectadores. Diante da tela acontece uma horizontalização de nossa condição, até nas posturas dos corpos, professor e alunos não estão mais contrapostos em dois lados, mas se viram para juntos assistir ao filme, se colocam no mesmo lugar, com a tela como foco de atenção. Esse lugar do espectador, entretanto, não é simples. Para Comolli (2008), assistimos hoje a uma luta feroz por duas concepções de espectador: a primeira que quer a alienação e a submissão do mesmo pela dependência do divertimento e o controle da subjetividade, e a segunda que postula a promessa de maior liberdade e responsabilidade dos sujeitos-espectadores pela intensificação das experiências subjetivas e pela possibilidade de desenvolver uma consciência crítica e criativa. Fica claro que qualquer redução do cinema ao entretenimento ou à lógica do espetáculo retira o próprio cinema da cena educacional.

Dessa forma, essas duas leis podem, em longo prazo, ampliar o repertório fílmico dos espectadores, apresentar outras formas de produzir o audiovisual, 
formar novos gostos e contribuir para que o espaço das mídias seja mais democrático e menos globalizante/desglobalizante ${ }^{38}$.

Bourdieu (2013), em texto intitulado Gostos de classe e estilos de vida ${ }^{39}$, apresenta uma questão bastante cara às experiências culturais, o conceito de habitus:

As práticas e as propriedades constituem uma expressão sistemática das condições de existência (aquilo que chamamos "estilo de vida") porque são o produto do mesmo operador prático, o habitus - sistema de disposições duráveis e transferíveis que exprime sob a forma de preferências sistemáticas as necessidades objetivas das quais ele é produto. (p. 73).

Para o autor, não é possível traçar uma relação direta e definitiva entre alto salário e gosto de luxo e entre baixo salário e gosto modesto, porém, essa relação existe, apesar das transitoriedades e transversalidades e são essas relações que criam o habitus, que está ligado ao estilo de vida ou modo com que as pessoas vivenciam os diversos dispositivos culturais. Seguindo tal premissa, o autor entende que a classe popular tem preferências pela cultura popular, enquanto a burguesia se interessa pela cultura erudita:

Os integrantes das classes populares e as frações menos ricas em capital cultural das classes médias recusam sistematicamente a sofisticação propriamente estética quando a encontram em espetáculos que Ihes são familiares, como os programas de variedades televisionadas. Do mesmo modo que no cinema muitas vezes fica desconcertado com os flash-backs, o público popular gosta de intrigas lógicas e cronologicamente orientadas para um happy end e se situa melhor em situações e personagens simples do que nas "histórias" ambíguas e simbólicas, sem ordem aparente e remetendo a experiências e problemas totalmente estranhos à experiência ordinária. (Bourdieu, 2013, p. 81-82)

Apesar de defender, no início do seu texto, que as relações entre a posição social e o gosto não são irreversíveis e nem diretas, ao apresentar sua pesquisa, Bourdieu (2013) cria convenções diretas entre gosto e classe social. Sua pesquisa veio a público em 1976 e foi problematizada, anos depois, por estudiosos que tratam das relações entre os meios de comunicação, cultura e poder. Nas palavras de García Canclini (2015, p. 22):

Se estamos numa época pós e multi, se há tempos é impossível instalar-se no marxismo, nos estruturalismo ou outra teoria como se fosse a única, o trabalho conceitual precisa aproveitar diferentes contribuições teóricas, debatendo suas interseções. Depois de utilizar durante anos a concepção bourdieana - ela mesma uma teoria que articula e discute Marx, Weber e Durkheim - para realizar investigações sobre campos intelectuais, consumos culturais e o vínculo sobre sociedade-cultura-política, avalio melhor os limites dos seus enfoques.

\footnotetext{
${ }^{38}$ Usei a expressão globalizante/desglobalizante inspirada em García Canclini (2015), pois o que vemos hoje não é uma globalização de fato, mas o domínio de filmes estadunidenses no cotidiano brasileiro, como já apresentado neste trabalho.

${ }^{39}$ Escrito em 1976, o artigo foi publicado no Brasil em 1983, em edição organizada por Renato Ortiz, atualizada em 2013.
} 
O autor ainda afirma que as contribuições de Bourdieu são importantes e que foram de extrema relevância para sua época, porém, nas sociedades de nossa época, a configuração dos sujeitos se dá de maneira muito mais dinâmica. Dessa forma, ele aposta que as ligações entre o público e as práticas culturais podem ser sempre reestabelecidas:

Embora o habittus tenda a reproduzir as condições objetivas que o engendram, um novo contexto, a abertura de possibilidades históricas diferentes, permite reorganizar as disposições adquiridas e produzir práticas transformadoras. (García Canclini, 2015, p. 197).

García Canclini (2015) acredita que faltou ao investigador francês atentarse mais para as práticas e menos para os processos de reprodução:

Embora Bourdieu reconheça esta diferença entre habittus e prática, detém-se mais no primeiro do que nas segundas. [...] Não examina, por isso, como o habittus pode variar segundo o projeto de reprodução ou transformação de diferentes classes e grupos. (García Canclini, 2015, p. 197).

As leis apresentadas nesta seção podem ser vistas como práticas possíveis na mudança do cenário e na democratização de acesso a diferentes narrativas. Penso que o espaço escolar tem enorme responsabilidade nisso, portanto, colocar a lei ํㅜ 13.006/14 em prática deve ser compromisso de todos os atores que acreditam que a educação pode ser mais do que a reprodução de valores e de condições sociais.

$\mathrm{Na}$ escola em que a pesquisa foi realizada, por exemplo, não existe uma proposta com visualização de filmes em seu projeto pedagógico, mas há espaços físicos e curriculares que permitem a abertura para isso. Inclusive, pude perceber que os alunos veem filmes com frequência, principalmente nos projetos que ocorrem no contraturno. Assim, o espaço dos projetos poderia ser pensado para atender a essa demanda, com a criação de um projeto específico para visualização e produção audiovisual.

É importante, ainda, mencionar que há na biblioteca da escola uma caixa com vários filmes que são usados pelos professores em momentos emergenciais, quando falta um professor e o outro fica com uma turma cheia, em momentos de descontração, ou mesmo quando alguma atividade ao ar livre não pode acontecer por causa de chuva. Porém, o acervo de filmes que eu pude identificar nessa caixa não é diferente daqueles que estão no gosto dos alunos, gosto este que não pode ser considerado definitivo, visto que muitos deles só conhecem esse tipo de narrativa audiovisual, portanto, só gostam dele por isso, não há outro para que possam comparar. Acredito que a escola pode pensar maneiras de levar outros filmes para compor o acervo e levar a seus alunos a 
diversidade que eles ainda não conhecem por falta de acesso. Acredito, ainda, que é importante não só ver os filmes, mas discutir sobre eles, inclusive questionar por que uma mesma forma de contar histórias faz tanto sucesso.

Dessa forma, se a escola pudesse apresentar outros filmes ou outras maneiras de vê-los, talvez os alunos pudessem se interessar por eles. Ou, ainda, segundo Bergala (2008, p. 46): "Oferecer aos alunos outras referências e abordar com eles os filmes com confiança, sem uma desconfiança prévia muito marcada, seria sem dúvida, hoje, a verdadeira resposta aos filmes ruins."

Vale, inclusive, discutir que nem todo produto audiovisual padronizado precisa ser classificado como ruim, desenvolvendo assim a criticidade na leitura fílmica e contribuir neste debate para mudar o olhar até de muitos professores que ainda resistem ao audiovisual no espaço escolar.

\section{3}

\section{Padronização de representação das juventudes}

Durante a pesquisa, em vários momentos, eu disse aos participantes que o resultado final da visualização dos filmes, das rodas de conversas e das atividades planejadas durante o ano de 2016 no projeto Contadores de História seria uma tese escrita por mim em que eles seriam os personagens, porém, eu não poderia usar seus nomes no texto e queria que cada um deles escolhesse o nome pelo qual quisesse ser identificado.

Na última atividade, em que fiz um pequeno balanço do ano com eles, pedi que escolhessem três nomes pelos quais eles gostariam de ser identificados e informei que usaria um deles na tese. A pergunta foi formulada da seguinte maneira: "Na minha tese de doutorado, quando eu for falar de você, usarei um apelido (ou nome fictício). Como você gostaria de ser chamado? Escolha três nomes de personagens de filmes e justifique sua escolha."

Antes que eles começassem a responder, alguns jovens perguntaram se poderia ser outros nomes que não só de personagens de filmes, se poderia, por exemplo, ser o nome de uma atriz no lugar do nome da personagem, ou de uma cantora, um jogador de futebol ou personagens de algum livro. Eu aceitei essas outras opções e disse a eles que escolheria entre as três sugestões dadas, pois corria o risco de muitos escolherem o mesmo nome.

Participaram desta atividade 30 jovens, sendo 16 meninas e 14 meninos. Os que não fizeram a atividade ganharam codinomes escolhidos por mim a partir 
das preferências demonstradas ao longo da pesquisa. Para fazer a seleção do nome, optei sempre pela primeira escolha do aluno, só passei para a segunda ou terceira opções quando o nome preferencial já tinha sido dado a outro aluno.

Os nomes escolhidos foram: Aline Barros, Bella I, Homem-Aranha, Batman, Hulk, Homem de Ferro, Wolverine, Emma Watson, Kaulder, Claire, Lúcia, Alice $\mathrm{I}^{40}$, Bela II, Malévola, Thor, Lince Negra, Luna, Mercúrio, Kauan, Olaf, Harry Potter, Coringa, Aruna, Troll, Owen, Maria, Alice II, Hazel Graze, João e Lola. Os nomes dados por mim: Edward, Cristiano Ronaldo, Augustus, Justin Bibier, He-Man, Susana e Tati.

Grande parte dos nomes escolhidos é de personagens de filmes que vimos durante o desenvolvimento da pesquisa, porém outros fazem parte da cultura audiovisual desses jovens e, a partir deles, é possível fazer uma análise dos materiais midiáticos que chegam até esses sujeitos de pesquisa e que, de certa forma, seguem um padrão, inclusive no que diz respeito à composição dos personagens, se levarmos em conta os filmes vistos durante a pesquisa e outros filmes e programas de TV mencionados por eles nas atividades de pesquisa. Para facilitar esta análise, no quadro a seguir apresento de forma resumida quem são as personagens escolhidas:

\footnotetext{
${ }^{40}$ Duas alunas escolheram Alice e outros dois nomes que já haviam sido escolhidos, como consegui que todos os outros alunos fossem chamados por um dos nomes que escolheram, para seguir a mesma norma, uma será Alice I e outra será Alice II. O mesmo aconteceu com o nome Bela, uma escolheu a Bella do Crepúsculo (Bella I) e outra a Bela do filme $A$ Bela e a Fera (Bela II).
} 


\begin{tabular}{|c|c|c|}
\hline $\begin{array}{c}\text { Nome } \\
\text { escolhido }\end{array}$ & Quem é? & Breve história \\
\hline $\begin{array}{l}\text { Aline } \\
\text { Barros }\end{array}$ & Cantora Gospel brasileira. & $\begin{array}{l}\text { Nasceu em uma família evangélica e desde } \\
\text { muito cedo é cantora gospel. Faz } \\
\text { apresentações para grandes públicos, } \\
\text { apresenta-se em canais de TV aberta e tem } \\
\text { gravações para o público infantil. }\end{array}$ \\
\hline Bella I & $\begin{array}{l}\text { Protagonista do filme } \\
\text { Crepúsculo. }\end{array}$ & $\begin{array}{l}\text { Interpretada pela atriz Kristen Stewart, é a } \\
\text { mocinha da saga Crepúsculo e namorada de } \\
\text { Edward. }\end{array}$ \\
\hline $\begin{array}{l}\text { Homem- } \\
\text { Aranha }\end{array}$ & $\begin{array}{l}\text { Herói de vários filmes de } \\
\text { Hollywood, também pode } \\
\text { ser visto em desenhos } \\
\text { animados e jogos. O } \\
\text { primeiro filme do super- } \\
\text { herói é de } 1977 \text { e o último } \\
\text { (Homem Aranha: de volta } \\
\text { ao lar) estreou em } 6 \text { de } \\
\text { julho de } 2017 \text { no Brasil. }\end{array}$ & $\begin{array}{l}\text { É um personagem das histórias em } \\
\text { quadrinhos do Universo Marvel, publicadas } \\
\text { pela Marvel Comics, criado em 1941. Tanto } \\
\text { nos filmes como nos quadrinhos, temos Peter } \\
\text { Parker, um estudante universitário e fotógrafo } \\
\text { de um jornal que foi picado por uma aranha e } \\
\text { ganhou superpoderes. }\end{array}$ \\
\hline Batman & $\begin{array}{l}\text { É a identidade secreta de } \\
\text { Bruce Wayne. Herói de } \\
\text { vários filmes de } \\
\text { Hollywood, dos desenhos } \\
\text { animados e quadrinhos. }\end{array}$ & $\begin{array}{l}\text { É um personagem das histórias em } \\
\text { quadrinhos publicadas pela DC Comics. Foi } \\
\text { criado pelo escritor Bill Finger e pelo artista } \\
\text { Bob Kane e apareceu pela primeira vez na } \\
\text { revista de maio de } 1939 \text {. Ao contrário dos } \\
\text { outros super-heróis, ele não tem } \\
\text { superpoderes, usa de seu intelecto para } \\
\text { proteger a cidade fictícia de Gotham City. }\end{array}$ \\
\hline Hulk & $\begin{array}{l}\text { Herói de inúmeros filmes e } \\
\text { desenhos animados. }\end{array}$ & $\begin{array}{l}\text { Na história original dos quadrinhos, Hulk é o } \\
\text { selvagem e poderoso alter ego do Dr. Robert } \\
\text { Bruce Banner, um cientista que foi atingido } \\
\text { por raios gama enquanto salvava um } \\
\text { adolescente durante o teste militar de uma } \\
\text { bomba desenvolvida por ele. É um } \\
\text { personagem das histórias em quadrinhos do } \\
\text { Universo Marvel, publicadas pela Marvel } \\
\text { Comics, criado em } 1962 \text {. }\end{array}$ \\
\hline $\begin{array}{l}\text { Homem } \\
\text { de Ferro }\end{array}$ & $\begin{array}{l}\text { Assim como o Homem- } \\
\text { Aranha, Hulk, Batman e } \\
\text { outros, ele nasceu nos } \\
\text { quadrinhos, passou a } \\
\text { desenho animado e } \\
\text { aparece em vários filmes } \\
\text { de Hollywood. }\end{array}$ & $\begin{array}{l}\text { É um personagem dos quadrinhos publicados } \\
\text { pela Marvel Comics. Sua identidade } \\
\text { verdadeira é a do empresário e bilionário } \\
\text { Tony Stark, que usa armaduras de alta } \\
\text { tecnologia no combate ao crime. Foi criado } \\
\text { em } 1963 .\end{array}$ \\
\hline Wolverine & $\begin{array}{l}\text { Personagem do filme } X \text { - } \\
\text { Men: dias de um futuro } \\
\text { esquecido e da cinessérie } \\
X-M e n .\end{array}$ & $\begin{array}{l}\text { É um mutante que possui sentidos sobre- } \\
\text { humanos, atributos físicos melhorados e uma } \\
\text { poderosa capacidade regenerativa. É um } \\
\text { personagem das histórias em quadrinhos do } \\
\text { Universo Marvel, publicadas pela Marvel } \\
\text { Comics. Vivido na série de filmes X-Men pelo } \\
\text { ator Hugh Jackman. }\end{array}$ \\
\hline $\begin{array}{l}\text { Emma } \\
\text { Watson }\end{array}$ & $\begin{array}{l}\text { Atriz da cinessérie Harry } \\
\text { Potter. }\end{array}$ & $\begin{array}{l}\text { E atriz britânica, conhecida por interpretar } \\
\text { Hermione Granger nos filmes da série Harry } \\
\text { Potter e também a protagonista de } A \text { Bela e a } \\
\text { Fera, além de outros filmes dirigidos ao } \\
\text { público jovem. }\end{array}$ \\
\hline
\end{tabular}




\begin{tabular}{|c|c|c|}
\hline $\begin{array}{c}\text { Nome } \\
\text { escolhido }\end{array}$ & Quem é? & Breve história \\
\hline Kaulder & $\begin{array}{l}\text { Protagonista do filme } O \\
\text { último caçador de bruxas. }\end{array}$ & $\begin{array}{l}\text { Vivido por Vin Diesel, ator da cinessérie } \\
\text { Velozes e furiosos, Kaulder é um imortal } \\
\text { caçador de bruxas que tem como tarefa salvar } \\
\text { Nova lorque. }\end{array}$ \\
\hline Claire & $\begin{array}{l}\text { Personagem do filme } \\
\text { Jurassic World: o mundo } \\
\text { dos dinossauros. }\end{array}$ & $\begin{array}{l}\text { Interpretada por Bryce Dallas Howard é a } \\
\text { mocinha do filme e gerente de operações do } \\
\text { Jurassic Park. }\end{array}$ \\
\hline Lúcia & $\begin{array}{l}\text { Uma das protagonistas do } \\
\text { filme As crônicas de } \\
\text { Nárnia: o Leão, a Feiticeira } \\
\text { e o Guarda-Roupa. }\end{array}$ & $\begin{array}{l}\text { Interpretada pela atriz britânica Georgie } \\
\text { Henley, é a irmã mais nova de Pedro, Suzana } \\
\text { e Edmundo. É responsável pela descoberta } \\
\text { de Nárnia, um mundo paralelo. }\end{array}$ \\
\hline Alice I & $\begin{array}{l}\text { Protagonista de Alice } \\
\text { através do espelho. }\end{array}$ & $\begin{array}{l}\text { Vivida pela atriz australiana de ascendência } \\
\text { polonesa Mia Justine Reid. Encontra um } \\
\text { espelho mágico numa festa, atravessa este } \\
\text { espelho e vai parar no país das Maravilhas, } \\
\text { onde sua função é ajudar o chapeleiro } \\
\text { mágico. }\end{array}$ \\
\hline Bela II & $\begin{array}{l}\text { Protagonista do filme } A \\
\text { Bela e a Fera. }\end{array}$ & $\begin{array}{l}\text { Interpretada pela atriz britânica Emma Watson } \\
\text { é a mocinha do filme inspirado no conto de } \\
\text { fadas de mesmo nome. }\end{array}$ \\
\hline Malévola & $\begin{array}{l}\text { Personagem do filme } \\
\text { Malévola. }\end{array}$ & $\begin{array}{l}\text { Interpretada por Angelina Jolie. Esta quando } \\
\text { jovem, vive uma desilusão amorosa que a } \\
\text { transforma em uma mulher vingativa. }\end{array}$ \\
\hline Thor & $\begin{array}{l}\text { Personagem da mitologia } \\
\text { germânica, conhecido } \\
\text { como Deus do Trovão. Foi } \\
\text { transformado em } \\
\text { quadrinhos e teve versões } \\
\text { em desenho animado e } \\
\text { filmes. }\end{array}$ & $\begin{array}{l}\text { Este personagem teve versões em } \\
\text { quadrinhos em editoras como Fox Feature } \\
\text { Syndicate e DC Comics, porém, a sua versão } \\
\text { mais famosa é da Marvel Comics, foi também } \\
\text { para o cinema. Sua arma é um martelo, } \\
\text { referência à cultura viking. }\end{array}$ \\
\hline $\begin{array}{l}\text { Lince } \\
\text { Negra }\end{array}$ & $\begin{array}{l}\text { Personagem do filme } X- \\
\text { Men: dias de um futuro } \\
\text { esquecido. }\end{array}$ & $\begin{array}{l}\text { É uma personagem das histórias em } \\
\text { quadrinhos do Universo Marvel, publicadas } \\
\text { pela Marvel Comics. No filme é vivida pela } \\
\text { atriz Ellen Page. Possui a capacidade de } \\
\text { teletransporte e tem a missão de levar } \\
\text { Wolverine para o passado no filme de } 2014 \text {. }\end{array}$ \\
\hline Luna & $\begin{array}{l}\text { Personagem do desenho } \\
\text { animado brasileiro O show } \\
\text { da Luna. }\end{array}$ & $\begin{array}{l}\text { É uma série de TV de animação brasileira } \\
\text { criada e dirigida por Célia Catunda e Kiko } \\
\text { Mistrorigo, produzida por Ricardo Rozzino, da } \\
\text { produtora TV PinGuim, é exibida na Discovery } \\
\text { Kids. Foi exportada para os Estados Unidos e } \\
\text { países da Europa e mostra as aventuras de } \\
\text { Lola, uma menina de seis anos de idade que } \\
\text { adora ciências. É recomendado para o público } \\
\text { infantil. }\end{array}$ \\
\hline Mercúrio & $\begin{array}{l}\text { Personagem do filme } X- \\
\text { Men: dias de um futuro } \\
\text { esquecido. }\end{array}$ & $\begin{array}{l}\text { E um personagem das histórias em } \\
\text { quadrinhos do Universo Marvel, publicadas } \\
\text { pela Marvel Comics. No filme é vivido por } \\
\text { Evan Peters. Ele tem o poder da velocidade, } \\
\text { podendo viajar mais rápido que a velocidade } \\
\text { do som. }\end{array}$ \\
\hline
\end{tabular}




\begin{tabular}{|c|c|c|}
\hline $\begin{array}{c}\text { Nome } \\
\text { escolhido }\end{array}$ & Quem é? & Breve história \\
\hline Kauan & $\begin{array}{l}\text { O aluno escolheu este } \\
\text { nome por ser um nome } \\
\text { bonito. }\end{array}$ & $\begin{array}{l}\text { Segundo dados do IBGE (2010), este nome e } \\
\text { suas variantes (Cauã, Kauam, Cauam, Kauã) } \\
\text { cresceu } 3.924 \% \text { nos anos 2000. Uma das } \\
\text { hipóteses para este crescimento é o sucesso } \\
\text { do ator da Rede Globo de Televisão Cauã } \\
\text { Reymond. }\end{array}$ \\
\hline Olaf & $\begin{array}{l}\text { Personagem do filme } \\
\text { Frozen: uma aventura } \\
\text { congelante. }\end{array}$ & $\begin{array}{l}\text { Olaf é um boneco de neve, criado por Elsa, } \\
\text { que ganha vida. Ele ajuda as irmãs Elsa e } \\
\text { Anna a vencerem vários obstáculos na } \\
\text { narrativa. }\end{array}$ \\
\hline $\begin{array}{l}\text { Harry } \\
\text { Potter }\end{array}$ & $\begin{array}{l}\text { Protagonista da cinessérie } \\
\text { Harry Potter. }\end{array}$ & $\begin{array}{l}\text { Interpretado pelo ator britânico Daniel } \\
\text { Radcliffe é o bruxo mais famosos da Escola } \\
\text { de Magia e Bruxaria de Hogwarts, onde se } \\
\text { passa a narrativa. }\end{array}$ \\
\hline Coringa & $\begin{array}{l}\text { É o inimigo } n^{\circ} 1 \text { do } \\
\text { Batman. Está em todos os } \\
\text { filmes e desenhos } \\
\text { animados do super-herói. }\end{array}$ & $\begin{array}{l}\text { É um supervilão que apareceu inicialmente } \\
\text { nos quadrinhos publicados pela DC Comics. } \\
\text { Está presente desde a revista número } 1 \text { do } \\
\text { Batman. }\end{array}$ \\
\hline Aruna & $\begin{array}{l}\text { Personagem da novela } A \\
\text { terra prometida produzida } \\
\text { e exibida pelo canal aberto } \\
\text { TV Record. }\end{array}$ & $\begin{array}{l}\text { Vivida pela atriz Thais Melchior, é uma das } \\
\text { mocinhas da narrativa. }\end{array}$ \\
\hline Troll & $\begin{array}{l}\text { Personagem da animação } \\
\text { Trolls (2016). }\end{array}$ & $\begin{array}{l}\text { Os Trolls são um povo feliz que vivem numa } \\
\text { floresta, mas são perseguidos pelos Bergens. } \\
\text { A narrativa gira em torno das aventuras } \\
\text { daqueles para se livrarem de seus inimigos e } \\
\text { continuarem felizes. }\end{array}$ \\
\hline Owen & $\begin{array}{l}\text { Personagem do filme } \\
\text { Jurassic World: o mundo } \\
\text { dos dinossauros. }\end{array}$ & $\begin{array}{l}\text { Interpretado por Chris Pratt, é um ex-militar } \\
\text { estadunidense que cuida dos dinossauros do } \\
\text { parque e os treina. Tem a missão de salvar o } \\
\text { parque do ataque de um dos dinossauros que } \\
\text { foi criado geneticamente. }\end{array}$ \\
\hline Maria & $\begin{array}{l}\text { Protagonista do filme João } \\
\text { e Maria: caçadores de } \\
\text { bruxas. }\end{array}$ & $\begin{array}{l}\text { Interpretada pela atriz britânica Gemma } \\
\text { Arterton. É responsável, junto com seu irmão, } \\
\text { de eliminar as bruxas negras de um lugarejo } \\
\text { na idade média. }\end{array}$ \\
\hline Alice II & $\begin{array}{l}\text { Protagonista do filme Alice } \\
\text { através do espelho. }\end{array}$ & $\begin{array}{l}\text { Vivida pela atriz australiana de ascendência } \\
\text { polonesa Mia Justine Reid. Encontra um } \\
\text { espelho mágico numa festa, atravessa este } \\
\text { espelho e vai parar no país das Maravilhas, } \\
\text { onde sua função é ajudar o chapeleiro } \\
\text { mágico. }\end{array}$ \\
\hline $\begin{array}{l}\text { Hazel } \\
\text { Grace }\end{array}$ & $\begin{array}{l}\text { Protagonista do filme } A \\
\text { culpa é das estrelas. }\end{array}$ & $\begin{array}{l}\text { Vivida por Shailene Woodley da série de } \\
\text { filmes Divergente. É a mocinha sofredora do } \\
\text { filme, que com câncer no pulmão, conhece } \\
\text { Augustus e juntos vão conhecer a Holanda. }\end{array}$ \\
\hline João & $\begin{array}{l}\text { Protagonista do filme João } \\
\text { e Maria: caçadores de } \\
\text { bruxas. }\end{array}$ & $\begin{array}{l}\text { Vivido por Jeremy Lee Renner, um ator, } \\
\text { produtor cinematográfico, maquiador e ex- } \\
\text { músico estadunidense. É responsável, junto } \\
\text { com sua irmã, por eliminar as bruxas negras } \\
\text { de um lugarejo na idade média. }\end{array}$ \\
\hline
\end{tabular}




\begin{tabular}{|c|c|c|}
\hline $\begin{array}{c}\text { Nome } \\
\text { escolhido }\end{array}$ & Quem é? & Breve história \\
\hline Lola & $\begin{array}{l}\text { Personagem da animação } \\
\text { inglesa Charlie e Lola. }\end{array}$ & $\begin{array}{l}\text { Charlie e Lola são duas personagens criadas } \\
\text { pela escritora inglesa Lauren Child. Os dois } \\
\text { irmãos foram lançados primeiramente em } \\
\text { uma série de livros infantis e logo depois em } \\
\text { uma série de televisão. }\end{array}$ \\
\hline Edward ${ }^{41}$ & $\begin{array}{l}\text { Protagonista do filme } \\
\text { Crepúsculo. }\end{array}$ & $\begin{array}{l}\text { Interpretado pelo ator, modelo e músico } \\
\text { britânico, Robert Pattinson, conhecido por } \\
\text { interpretar o bruxo Cedric Diggory no filme } \\
\text { Harry Potter e o cálice de fogo. É o vampiro } \\
\text { da série Crepúsculo. }\end{array}$ \\
\hline $\begin{array}{l}\text { Cristiano } \\
\text { Ronaldo }\end{array}$ & $\begin{array}{l}\text { Jogador da seleção } \\
\text { portuguesa de futebol e do } \\
\text { time espanhol Real } \\
\text { Madrid. }\end{array}$ & $\begin{array}{l}\text { Foi eleito melhor jogador do mundo pela } \\
\text { Federação Internacional de Futebol (FIFA) } \\
\text { quatro vezes }(2008,2013,2014,2016) \text {. }\end{array}$ \\
\hline Augustus & $\begin{array}{l}\text { Protagonista do filme } A \\
\text { culpa é das estrelas. }\end{array}$ & $\begin{array}{l}\text { Interpretado pelo ator, cantor e DJ Ansel } \\
\text { Elgort, que já havia sido par romântico de } \\
\text { Shailene Woodley na série de filmes } \\
\text { Divergente. Na narrativa, conhece a mocinha } \\
\text { num grupo de apoio de pessoas com câncer e } \\
\text { juntos fazem uma viagem para Holanda. }\end{array}$ \\
\hline $\begin{array}{l}\text { Justin } \\
\text { Bibier }\end{array}$ & Cantor pop canadense. & $\begin{array}{l}\text { Faz shows para multidões em todo o mundo. } \\
\text { É considerado um ídolo pop adolescente e } \\
\text { está sempre nas revistas de celebridades. }\end{array}$ \\
\hline He-Man & $\begin{array}{l}\text { É um personagem da linha } \\
\text { de brinquedos Master of } \\
\text { the universe, foi dos } \\
\text { quadrinhos (da DC } \\
\text { Comics) para o desenho } \\
\text { animado. }\end{array}$ & $\begin{array}{l}\text { E um espírito poderoso que incorpora no } \\
\text { jovem Adam, um príncipe que vive no planeta } \\
\text { Etérnia, um mundo medieval, mas repleto de } \\
\text { tecnologias avançadas. Sua missão é impedir } \\
\text { o vilão Esqueleto de dominar o castelo de } \\
\text { Grayskull e assim ter o controle de todo o } \\
\text { universo. }\end{array}$ \\
\hline Susana & $\begin{array}{l}\text { Uma das protagonistas do } \\
\text { filme As crônicas de } \\
\text { Nárnia: o Leão, a Feiticeira } \\
\text { e o Guarda-Roupa. }\end{array}$ & $\begin{array}{l}\text { Interpretada pela atriz britânica Anna } \\
\text { Popplewell, é a irmã mais velha de Pedro, } \\
\text { Lúcia e Edmundo. Junto com os irmãos, } \\
\text { salvam Nárnia da Feiticeira Branca. }\end{array}$ \\
\hline Tati & $\begin{array}{l}\text { Uma das protagonistas do } \\
\text { curta-metragem } \\
\text { Confusões de } \\
\text { adolescente. }\end{array}$ & $\begin{array}{l}\text { Vivida pela atriz lasmin Farias, é a } \\
\text { responsável por várias cenas de confusão } \\
\text { criadas na narrativa, é apaixonada por Pedro, } \\
\text { o protagonista. }\end{array}$ \\
\hline \multicolumn{3}{|c|}{$\begin{array}{l}\text { Quadro } 8 \text { - Nomes escolhidos pelos participantes das oficinas e breve história } \\
\text { das personagens } \\
\text { Fonte: Elaboração própria. }\end{array}$} \\
\hline
\end{tabular}

\footnotetext{
${ }^{41}$ Deste nome em diante, eu escolhi o codinome dos sujeitos de pesquisa, pois no dia da atividade de escolha dos codinomes estes não participaram das atividades.
} 
Ao levar em conta, para essa análise, apenas os 30 primeiros nomes, ou seja, aqueles escolhidos e registrados na atividade realizada na oficina, algumas questões me chamaram a atenção:

- uma das meninas, escolheu como primeira opção uma personagem masculina (Owen, do filme Jurassic World: o mundo dos dinossauros);

- o menino que escolheu o nome Kauan, o escolheu porque, para ele, é um nome bonito, porém, é também o nome de um dos atores de maior sucesso da televisão brasileira da atualidade e, conforme apresentado no quadro anterior, o registro deste nome em crianças nascidas a partir dos anos 2000 aumentou mais de mil por cento;

- dos 14 meninos que participaram da pesquisa, 7 escolheram nomes de super-heróis (Homem-Aranha, Batman, Hulk, Homem de Ferro, Wolverine, Thor e Mercúrio); um escolheu o nome de um supervilão (Coringa); dois escolheram nomes de personagens fortes e responsáveis por resolver os conflitos das narrativas (Kaulder e João); dois escolheram nomes de personagens não humanos (Troll e Olaf); e um optou pelo nome de um adolescente com poderes mágicos, que é quase um superherói (Harry Potter), pois apesar da aparência frágil, tem a magia como ponto forte; o último escolheu Kauan, nome já mencionado. Este tópico me surpreendeu pelo número de super-heróis mencionados pelos meninos, o que fez emergir uma subcategoria que será explorada num tópico específico deste capítulo;

- entre os nomes escolhidos pelas meninas, há 2 nomes de pessoas reais (Aline Barros e Emma Watson); uma personagem de novela (Aruna); 2 personagens de desenhos animados infantis (Luna e Lola); e todas as outras são personagens de filmes vistos ou comentados em sala de aula durante a pesquisa (Alice I, Alice II, Bella I, Bela II, Claire, Lúcia, Malévola, Lince Negra, Maria, Hazel Grace).

É importante notar que das personagens ficcionais escolhidas, muitas existem em mais de um suporte midiático; os super-heróis, por exemplo, vão dos quadrinhos para os desenhos animados e logo em seguida para série de filmes. Alguns têm filmes próprios, mas também aparecem em outras narrativas, como é o caso, por exemplo, de Wolverine, que participa da série X-Men, mas também tem sua narrativa solo. Há aqueles que apareceram nos livros e foram para o cinema, alguns foram dos livros direto para a TV, outros são quadrinhos, desenhos animados e já existe a versão do brinquedo, o que aponta para o que 
Jenkins (2009) conceitua como convergência das mídias. Mesmo as personagens reais ganham capas de revista, programas de TV, ou seja, são levados para todos os espaços, a fim de atender ao público até o esgotamento. Segundo o autor:

Por convergência, refiro-me ao fluxo de conteúdos através de múltiplas plataformas de mídia, à cooperação entre múltiplos mercados midiáticos e ao comportamento migratório dos públicos dos meios de comunicação, que vão a quase qualquer parte em busca de experiências de entretenimento que desejam. Convergência é uma palavra que consegue definir transformações tecnológicas, mercadológicas, culturais e sociais, dependendo de quem está falando e do que imaginam estar falando. (Jenkins, 2009, p. 29).

Essa convergência leva o público a criar espaços de discussão em que analisam e debatem a representação das personagens nas diversas mídias. Fãs de quadrinhos, por exemplo, ficam inconformados com as mudanças sofridas por algumas personagens ao ganharem vida no cinema. Porém, mesmo a recepção negativa rende lucros às empresas envolvidas, pois garante o debate, a polêmica e a venda dos produtos. Segundo Jenkins (2009, p. 29): "No mundo da convergência das mídias, toda história importante é contada, toda marca é vendida e todo consumidor é cortejado por múltiplas plataformas de mídia."

Os nomes de personagens e celebridades escolhidos pelos sujeitos desta pesquisa me levam, ainda, à discussão proposta por Morin (1989) acerca do star system. Publicado originalmente em 1957 e só traduzido no Brasil em 1989, com o título "As estrelas: mito e sedução no cinema", o livro oferece uma perspectiva interessante para entendermos a maneira com que a indústria do entretenimento contribui para estabelecer relações entre os fãs e seus ídolos.

Para Morin (1989), alguns artistas estão vinculados a um mesmo tipo de personagem, mesmo que haja alguma flexibilidade, eles ficam presos a determinados padrões. Três exemplos já discutidos aqui confirmam essa ideia: o par romântico de A culpa é das estrelas e de Divergente é o mesmo: os atores Shailene Woodley e Ansel Elgort. Vin Diesel é sempre escalado para fazer homens fortes e dispostos a enfrentar todos os obstáculos para atingir seus objetivos e participa frequentemente de filmes cuja violência é evidenciada; os filmes Velozes e furiosos e $O$ último caçador de bruxas comprovam isso. A atriz Jennifer Lawrence estrelou dois filmes de ação de 2014 como heroína (X-Men: dias de um futuro esquecido e Jogos vorazes: a esperança - parte 1) e interpretou basicamente o mesmo tipo de personagem, ou seja, uma heroína em conflito e que no fim da narrativa consegue superar seus medos e vencer, pelo menos em parte, as batalhas. Todas as mocinhas escolhidas pelas jovens participantes desta pesquisa (expostas no Quadro 9) têm um padrão físico e 
estético muito parecidos (brancas, olhos claros, aparência frágil e, com exceção da personagem de A culpa é das estrelas, que vivenciava na narrativa um tratamento contra o câncer, todas têm longos cabelos lisos). Psicologicamente, suas personalidades transitam entre o exercício do poder e um conflito, que as impede de exercê-lo plenamente. Essa é a trama de todas as narrativas: a crise de identidade que essas personagens precisam passar para atingir seus objetivos.

A discussão do star system ganha ecos em Bergala (2008, p. 71), quando ele afirma:

O argumento de venda que se encontra hoje nos cartazes: do mesmo diretor de... (quando não: pelo produtor de...!) evidentemente não tem mais nada a ver com a política dos autores, na qual se trata de destacar a singularidade do cineasta. Cada novo filme de Hitchock, que foi o primeiro a anunciar seu nome como argumento de venda, surpreendia com relação ao anterior. Hoje, trata-se de apenas de garantir ao cliente que ele encontrará o mesmo produto e o mesmo prazer, numa política de marcas.

Segundo o autor, vende-se a perspectiva de encontrar elementos conhecidos do espectador, seja a atriz principal, os mesmos efeitos especiais ou a personagem vivida por determinado ator, em desempenho que lembra o último filme interpretado por ele.

O sistema de estrelato ou star system transforma pessoas comuns (o jogador de futebol, a cantora, a atriz que vive a mocinha no filme de grande bilheteria, o ator que interpreta o super-herói) em grandes estrelas que são imitados, vigiados, admirados pelo grande público. Sendo assim, eles passam até mesmo a colocarem-se no lugar da celebridade e querer pensar e agir da mesma forma que esta. Todos os nomes escolhidos pelos sujeitos desta pesquisa podem ser considerados estrelas midiáticas e, além de venderem filmes, aumentam as cifras de revistas, brinquedos e muitos outros produtos, estando todos vinculados a um padrão estético e de comportamento vendidos pela mídia.

Ao analisar filmes de guerra produzidos por Hollywood na década de 1980, Kellner (2001, p. 108) afirma: "A cultura da mídia produz imagens que mobilizam o desejo do espectador para certos modos de pensamento, comportamento e modelos que servem aos interesses da manutenção e da reiteração do status quo." Mais de 30 anos nos separam dos filmes analisados por Kellner, mas a lógica de produção e criação dos filmes e composição das personagens ainda é a mesma: satisfazer o público e criar nele uma sensação de proximidade com os astros e estrelas e, para isso, muitas vezes, as personagens são criadas para 
atender a uma linha de produção, ou seja, seguem modelos e características que já foram aprovados pelo grande público.

Em relação às características físicas das personagens dos filmes apresentados nesta pesquisa, como já mencionado, tanto as "mocinhas" quanto os "mocinhos" têm padrões físicos muito semelhantes, o que, por exemplo, nos remete à falta de representatividade das diversas etnias. Não há, nos filmes comentados, por exemplo, um negro em papel de destaque. O único filme com personagens negros é $X$-Men: dias de um futuro esquecido, que apresenta a personagem Vampira, vivida pela atriz Halle Berry, e o mutante Bishop, vivido por Omar Sy. Ambos aparecem em cenas curtas e são responsáveis por proteger os demais mutantes dos Sentinelas, mas não são o foco central da narrativa.

Apesar de cenas curtas e que poderiam ser interpretadas por qualquer outro ator ou atriz, já que em nenhum momento da narrativa a etnia deles é destacada ou mencionada, assim como das demais personagens, entendo que 0 fato de estes atores terem sido escalados aponta para o direcionamento político que esta marca de produtos midiáticos representa. Desde sua criação nos quadrinhos, em 1963, os X-Men têm uma atuação importante em defesa das minorias. Stan Lee e Jack Kirby, os criadores dos quadrinhos, criaram os mutantes na perspectiva de representarem alegoricamente todas as minorias (negros, homossexuais, imigrantes, judeus e outros) e nos quadrinhos, assim como nos filmes, o professor Xavier e Magneto representam as duas faces da luta pela igualdade, o primeiro propondo a união entre os diferentes e o outro, o rompimento e a luta pela igualdade de direitos. Nesse sentido, essa narrativa destoa das demais, visto que há, também no roteiro do filme, uma questão envolvendo a coletividade e o pertencimento forte a um grupo, o que leva as personagens a abrirem mão de questões pessoais em função dos demais. Nas demais narrativas, mesmo quando as personagens são responsáveis por salvar um grupo ou localidade, o fazem movidos por questões pessoais, tais como recompensa (João e Maria: caçadores de bruxas) ou proteção à família (Jogos vorazes: a esperança - parte 1).

Ainda sobre a questão da representatividade étnica, no filme João e Maria: caçadores de bruxas, as bruxas são divididas em dois grupos: as boas e as más, que são chamadas de "Bruxas Negras". Ao ouvir isso, o jovem que se autoidentificava como Homem-Aranha imediatamente questionou: "Aí, como eu sou negro, eu sou mau?" É bastante comum os suportes audiovisuais e também a literatura fazerem essa relação entre bondade e brancura, maldade e 
negritude, que são formas de representação carregadas e difusoras de preconceito. O questionamento do jovem é um indício de que essas representações precisam ser problematizadas.

No caso do filme visto, caracterizar as bruxas más como bruxas negras é colocá-las como ameaçadoras de uma ordem social, o que chamou a atenção do jovem para a reprodução de estereótipos, em geral aceitos sem muito questionamento.

Como mencionado em seção anterior, uma das atividades que desenvolvi com os jovens ao final da visualização do filme $A$ culpa é das estrelas foi a tentativa de recriação do roteiro, que como já mencionado, pouco foi modificado. Em relação às características das personagens principais (Hazel e Augustus), apenas um jovem mudou substancialmente as características físicas de Augustus. Ele deu a essa personagem suas próprias características físicas ("olhos verdes e pele negra"), tendo sido o único que de fato atribuiu características muito diferentes das originais. Eu tinha a expectativa de que outros fizessem o mesmo, seguindo a ideia de identificação comum entre o espectador e as personagens dos filmes a que assistem, mas todos os outros jovens caracterizaram Augustus e Hazel seguindo as mesmas características do filme: brancos, bonitos, olhos claros, altos, como se este fosse o padrão comum.

Ao comentar porque não mudou as características das personagens, a menina Malévola afirma: "Porque eles são todos bonitos." A partir dessa perspectiva, entendo que os sujeitos desta pesquisa já se acostumaram ao padrão estético definido por esse tipo de filme e, ao que parece, para eles as personagens que saem desse padrão são consideradas feias, por isso é melhor mantê-las como são.

É importante entender que a construção estética de personagens de narrativas audiovisuais está ligada a um discurso do que é belo, configurado e/ou reforçado pela indústria cultural e assimilado pelos consumidores como algo natural. Nesse sentido, cabe aqui a afirmação de Sefton e Martins (2004) que, ao pesquisarem as representações de corpo na literatura infantojuvenil, depararamse com um único padrão de beleza:

[...] ao trabalhar com conceitos de desnaturalização, de que padrões são construídos histórica, social e culturalmente, compreende-se que o corpo é significado e ressignificado ao longo do tempo e nas diferentes culturas. Portanto, cabe sublinhar o quanto cada época, cada sociedade, cada cultura, prescrevem o que é certo/errado, bonito/feio, saudável/não-saudável, estético/grotesco, sendo estes conceitos construídos por homens/mulheres, podendo ser datados e localizados no tempo, no espaço, nos discursos dominantes, e, portanto, não são naturais, não foram sempre assim e não o serão para todo o sempre. (p. 284). 
Nesta perspectiva, uma das maneiras de problematizar estes padrões estéticos é levantar a discussão em sala de aula ao tratarmos dessas narrativas padronizadas, sejam elas literárias ou audiovisuais contrapor as concepções culturais e naturais é sempre uma boa opção.

As personagens do filme $A$ culpa é das estrelas viajam para encontrar-se com Peter Van Houten (vivido por Wiliem Dafoe), um escritor de quem Hazel é fã. Na atividade desenvolvida após a visualização do filme, pedi aos jovens que escolhessem alguém do qual essas personagens poderiam ser fãs. Esta foi uma das poucas questões em que eles criaram outras possibilidades de reelaboração do roteiro, diferente das demais questões. Dos 27 respondentes, apenas 5 mantiveram o nome do escritor fictício, os demais trocaram para nomes de astros e estrelas da música ou do futebol. A maioria dos escolhidos são cantores brasileiros, o que pressupõe uma identificação deles com a situação vivida pelas personagens. As personalidades escolhidas pelos jovens para serem os ídolos de Hazel e Augustus estão apresentados no quadro a seguir:

\begin{tabular}{|l|l|c|}
\hline \multicolumn{1}{|c|}{ Nome } & \multicolumn{1}{c|}{ Quem é? } & Votos \\
\hline Anitta & Cantora brasileira de funk. & 06 \\
\hline Luan Santanna & Cantor brasileiro de música sertaneja. & 06 \\
\hline Zé Felipe & Cantor brasileiro de música sertaneja. & 05 \\
\hline Michael Jackson & $\begin{array}{l}\text { Foi um importante cantor estadunidense, } \\
\text { considerado o artista mais rico da história. }\end{array}$ & 02 \\
\hline Neymar & Jogador de futebol da seleção brasileira. & 02 \\
\hline Ludmilla & Cantora brasileira de funk. & 02 \\
\hline MC Tati Zaqui & Cantora brasileira de reggaeton. & 02 \\
\hline Justin Bibier & Cantor canadense de música pop. & 01 \\
\hline Cristiano Ronaldo & Jogador de futebol, considerado o melhor do mundo. & 01 \\
\hline Mano Brown & Rapper brasileiro. & 01 \\
\hline Paula Fernandes & Cantora brasileira de música sertaneja. & 01 \\
\hline Demi Lovato & Cantora e atriz estadunidense. & 01 \\
\hline Shakira & Cantora colombiana internacionalmente conhecida. & 01 \\
\hline Rihanna & Cantora nascida em Barbados e radicada nos & 01 \\
\hline Denzel Washington & estados Unidos. & 01 \\
\hline Katty Perry & Cantora estadunidense. & 01 \\
\hline MC Th & Cantor brasileiro de funk. & 01 \\
\hline Mc Rodolfinho & Cantor brasileiro de funk. & 01 \\
\hline Sorriso Maroto & Grupo de pagode. & 01 \\
\hline
\end{tabular}

Quadro 9 - Personalidades escolhidas para serem ídolos dos protagonistas de A culpa é das estrelas ${ }^{42}$

Fonte: Elaboração própria.

\footnotetext{
${ }^{42}$ No quadro constam 37 respostas somadas às 5 respostas que mantiveram o nome do escritor fictício da trama, cheguei a 42 respostas. Este número de respondentes ocorreu, pois os jovens poderiam escolher um ídolo para cada personagem, quando eles repetiram o nome do ídolo para os dois personagens, considerei o nome apenas uma vez.
} 
Essas escolhas evidenciam a presença de cantores e músicos brasileiros no universo cultural dos jovens participantes da pesquisa. Ritmos musicais como funk, sertanejo e pop fazem parte das referências culturais deles, pois foram os artistas destes gêneros os mais citados. Tanto os cantores nacionais quanto os de outros países e, com maior evidência, os estadunidenses, estão presentes no cotidiano deles, além disso, o futebol também aparece com dois ídolos, o brasileiro Neymar e o português Cristiano Ronaldo. É interessante notar que, no filme, as personagens viajaram para encontrar um escritor de romances do qual eles eram fãs, mas nenhum dos jovens escolheu como ídolo um autor de livros, nem mesmo aqueles que escreveram os livros que foram adaptados para os filmes de que eles gostam. A identificação mais direta parece ser mesmo com o audiovisual e a música, não com a literatura, mesmo eles tendo projetos escolares voltados à leitura e discussão de textos literários.

Ainda com relação à padronização na construção das personagens, esta gera, aparentemente, uma sensação de conforto no espectador, que pode ser comprovada, por exemplo, quando em outro momento da pesquisa foi pedido que eles recriassem o figurino da Katniss Everdeen, heroína vivida por Jennifer Lawrence no filme Jogos vorazes: a esperança - parte 1. Nessa atividade, muitos jovens optaram por fazer figurinos inspirados em outras personagens da ficção ou que estão em evidência na mídia, ou até mesmo figurinos que agradassem a eles.

Essa atividade consistia em desenhar em dois bonecos, o figurino da personagem e dizer em que ou em quem eles se inspiraram para criá-lo (Apêndice G). Selecionei algumas justificativas dadas na atividade, que mostram uma inspiração em outras personagens conhecidas no audiovisual. Eis o diálogo travado entre mim e eles durante esse momento:

Carla: O Wolverine está me dizendo aqui que fez o dele inspirado na Angelina Jolie em Tomb Raider, a Lara Croft.

Claire: Eu inspirei minha boneca no que eu vejo por aí.

Lince Negra: Os looks são inspirados no Superman, mas é um look mais para jantares, reuniões, etc. Eu escolhi me inspirar nele, pois sempre que falam em heróis, eu me lembro dele.

Mercúrio: Inspirado na Psylocke de X-Men Apocalipse.

Thor: Essas roupas foram inspiradas no X-Men e no Capitão América, mas acima de tudo no poder da mulher.

Homem de Ferro: Me inspirei em Tartarugas Ninjas porque elas são muito flexíveis e têm vários golpes maneiros.

He-Man: O primeiro é baseado na She-ra, uma mulher que só faz o bem e o segundo é baseado no filme Elektra, uma heroína em ação. 
Lola: Eu me inspirei em duas cantoras: Shakira e Beyoncé.

A personagem Lara Croft, inspiração do jovem Wolverine, é uma heroína dos jogos eletrônicos da série Tomb Raider, lançada em 1996. Ao todo, a série conta com seis jogos, com 89 milhões de unidades vendidas, que levaram Lara Croft para o "Guiness Book" como a heroína mais bem-sucedida no mundo dos games. Em 2001, o jogo virou filme e a atriz Angelina Jolie interpretou a protagonista. O filme Lara Croft: Tomb Raider (Simon West, 2001) arrecadou cerca de 274 milhões de dólares em bilheterias e se tornou o mais lucrativo estrelado por uma mulher e maior bilheteria de uma adaptação de jogo para o cinema. O filme teve uma continuação em 2003 (Lara Croft: Tomb Raider - a origem da vida [Jan de Bont, 2003]), também com Jolie no papel principal. Já está sendo gravado e deve estrear até 2018 o terceiro filme da série, que trará a atriz sueca Alicia Vikander como a protagonista.

Em relação ao figurino da heroína, são roupas esportivas, algumas remetem ao hipismo, sempre justas e sensuais e, além disso, ela aparece de cabelos muito longos, arrumados em uma trança ou rabo de cavalo. Em algumas cenas, a personagem usa óculos escuros.

A Psylocke, inspiração do jovem que se autoidentificava como Mercúrio, é uma personagem dos quadrinhos, do cinema e também dos games. No filme mencionado pelo jovem ( $X$-Men apocalipse), a mutante interpretada pela atriz estadunidense Olivia Munn aparece com maiô de látex e uma meia-calça de mesmo tecido com vários furos pela perna; muitos consideraram o figurino vulgar e, em entrevistas, na época do lançamento do filme, a atriz considerou o figurino sexy e fiel à personagem dos quadrinhos.

Elektra, a personagem dos quadrinhos Marvel, que foi uma das inspirações do jovem autoidentificado como He-man, foi eleita uma das cem mulheres mais sexy dos quadrinhos. Ela usa uma roupa vermelha bastante decotada e com inúmeras fendas, o que deixa o corpo bem evidenciado, além disso, usa os longos cabelos soltos e um lenço do mesmo tecido da roupa para compor o visual.

Os outros heróis e heroínas que inspiraram as criações dos participantes das oficinas usam macacões colados no corpo, feitos de material elástico como o látex e alguns, como Superman e She-ra, usam capas para compor o figurino. She-ra é uma das poucas heroínas que usa uma minissaia acompanhada de maiô e capa. 
É interessante notar que uma das meninas se inspirou em duas cantoras pop. Os figurinos de shows dessas cantoras são bem parecidos com as roupas das heroínas dos filmes de ação e quadrinhos. É possível dizer que, há, em certa medida, um padrão nas roupas de heroínas e estrelas da música pop internacional.

Foi possível perceber também que, apesar da proposta da atividade ser a de desenhar o figurino da personagem, quase a totalidade dos jovens participantes da pesquisa se preocuparam também com o cabelo, ou um adereço na cabeça, além disso, todos os cabelos são longos, o que ocorre também com as personagens que eles usaram como inspiração. Fica evidente a repetição de alguns elementos: botas quase sempre longas, roupas que destacam o corpo, como os corpetes e calças ou macacões bastante justos. Há, portanto, para estes jovens um modelo de herói ou heroína nos filmes de ação que passa não só por suas ações e poderes, mas também pelo cenário, comportamento e figuro usados.

Algumas alunas optaram por criar um figurino que elas gostariam de usar, sendo assim, inspiraram-se nos seus gostos para se vestir e suas falas evidenciam isso:

Porque eu gosto desta roupa, amo! (Aruna).

É uma roupa que combina com ela e se identifica com o meu estilo. (Bela II).

Essa roupa é baseada em mim. (Malévola).

Eu fiquei inspirada no meu jeito de vestir e várias outras maneiras. (Susana).

Para essas alunas, o figurino deixa de ser o de uma heroína e passa a ser o figurino que elas podem usar no dia a dia, ou seja, elas conseguem se ver no lugar da personagem, assim como o aluno que descreveu o Augustus, do filme $A$ culpa é das estrelas, com as características físicas dele e não mais do ator que o interpretava. A partir desses dados, cabe aqui ressaltar o que propõe MartínBarbero (2013, p. 236): "As pessoas vão ao cinema para se ver, numa sequência de imagens que mais do que argumentos lhes entrega gestos, rostos, modos de falar e caminhar, paisagens, cores."

Nesta atividade e em outras desenvolvidas durante a pesquisa, inclusive a da escolha dos nomes para serem usados nesta tese, pude notar uma forte relação entre os jovens pesquisados e os super-heróis, o que fez emergir, durante a análise, uma subcategoria que será discutida na subseção que segue. 


\subsection{1 \\ Os super-heróis e a cultura de massa}

Conforme apresentado no início desta seção, a subcategoria que trata dos super-heróis apareceu de maneira muito evidente em alguns momentos da pesquisa, principalmente na escolha dos meninos por codinomes dessas personagens. Os argumentos para eleger os nomes variavam desde o fato de serem fãs dessas personagens, até associar esses nomes à força e à imortalidade:

Porque o Homem-Aranha é meu herói desde criança! (Homem-Aranha).

Wolverine, Mercúrio e Hulk porque no filme estes personagens pra mim eles são os mais fodas! (Wolverine).

Kaulder é um personagem bem desenhado e no filme ele não morre. (Kaulder).

Thor, porque tenho aparência de um Deus Viking! Superman porque sou forte e capitão América por causa da minha bravura! (Thor).

Os exemplos apresentados evidenciam o super-herói como bravo, forte, imortal além de destacar a aparência e o fato de o personagem escolhido já fazer parte do imaginário dos sujeitos pesquisados.

Ao tratar da figura do herói, Feijó (1984) expõe a trajetória deste, começando pelo herói mitológico, que servia para justificar determinados feitos realizados por homens e que estes, aos poucos, chegavam ao patamar de deuses ou semideuses; apresenta fatos históricos, que também foram responsáveis pela mitificação de determinadas figuras, recorrendo também à literatura, que deu um tom de ficção a suas personagens épicas, capazes de vencer tudo e todos. O autor termina apresentando a indústria cultural, que conseguiu reunir todos esses heróis, transformando-os em símbolos da cultura de massa. Tais símbolos são altamente identificáveis e padronizados, conforme sugere a fala de uma das participantes da pesquisa: "Engraçado que todo filme que fala de poder, os poderosos nunca morrem, né!?" (Malévola).

O autor ainda faz a distinção entre o herói e o super-herói. Para ele, o herói está ligado a diferentes aspectos e a diversas culturas, vai dos clássicos deuses mitológicos (com poderes e imortalidades), passa por justiceiros, valentes e arruaceiros do bem, até chegar aos santos católicos, que têm em comum a possibilidade de resolver grandes problemas que afligem a determinado grupo, sociedade ou até mesmo à humanidade. Esse é o caso de João (João e Maria: caçadores de bruxas) e Kaulder ( $O$ último caçador de 
bruxas), personagens escolhidos por dois dos alunos, que conseguem salvar das bruxas das cidades em que os filmes se ambientam e, assim, libertam seus moradores - o que acontece usando força e perspicácia. Apesar de ficarem várias vezes diante da morte, eles conseguem cumprir seus objetivos.

Para o autor, o super-herói surge na indústria cultural através dos quadrinhos, indo depois para o cinema e a cultura de massas em geral. Ainda segundo Feijó (1984), enquanto o herói era inspirado em alguém real, ou seja, uma pessoa que fazia parte da sociedade e foi ganhando estima até tornar-se herói, o super-herói é fruto da fantasia:

[...] os super-heróis se incorporam aos mitos de nosso tempo, desenvolvendo-se num contexto de concentração econômica e alienação, mas menos perigosos do que muitas vezes se supõe. Ou seja: não dá para igualá-los aos mitos das sociedades primitivas pela simples razão de que nessas os indivíduos tinham seus heróis como reais (só que num outro tempo e espaço), ao passo que todos nós sabemos que os super-heróis são fruto de uma indústria altamente lucrativa, onde até o herói virou mercadoria. (Feijó, 1984, p. 92).

Porém, não podemos ignorar o potencial do super-herói para criação dos mitos da atualidade, mesmo que estes sejam descartáveis ou que não tenham a unanimidade do público, ainda assim são cultuados quase como os deuses da antiguidade. Eco (1970) nos lembra que os super-heróis foram criados pelos quadrinhos e hoje dominam os meios de comunicação de massa:

A civilização de massa oferece-nos um exemplo evidente de mitização na produção do mass media e, em particular, na indústria dos comic strips, as "estórias em quadrinhos": exemplo evidente e singularmente adequado ao nosso objetivo, porque aqui assistimos a co-participação popular de um repertório mitológico claramente instituído de cima, isto é criado por uma indústria jornalística, porém particularmente sensível aos caprichos do seu público, cuja exigência precisa enfrentar. (Eco, 1970, p. 244).

Vale ressaltar que todos os super-heróis escolhidos pelos alunos Homem-Aranha, Batman, Hulk, Wolverine, Homem de Ferro, Thor, Mercúrio são oriundos das histórias em quadrinhos (HQs), o que confirma a afirmação de Eco (1970) de que a indústria vai incorporando suas ofertas, seguindo os caprichos do público que atende. Alguns desses super-heróis, como Thor, partem das antigas narrativas mitológicas, vão para os quadrinhos e chegam aos cinemas. Outros, apesar de não virem de tão longe, ganham narrativas tão mitológicas quanto as de Thor e persistem no imaginário popular, como é o caso do Superman, um dos heróis mais populares do planeta, o primeiro super-herói de verdade (Feijó, 1984). Ao descrever o Superman, Eco (1970, p. 247) afirma que ele agrada ao cidadão comum, pois é um herói positivo: 
Superman é o mito típico de tal gênero de leitores: o Superman não é um terráqueo, mas chegou à Terra, ainda menino, vindo do planeta Crípton. Crípton estava para ser destruído por uma catástrofe cósmica e o pai do Superman, hábil cientista, conseguira pôr o filho a salvo construindo um veículo espacial. Crescido na Terra, o Superman vê-se dotado de poderes sobre-humanos. Sua força é praticamente ilimitada, ele pode voar a uma velocidade igual à da luz, e quando ultrapassa essa velocidade atravessa a barreira do tempo, e pode transferir-se para épocas. [...] é belo, humilde, bom e serviçal: sua vida é dedicada à luta contra as forças do mal e a polícia tem nele um colaborador incansável.

A maioria dos super-heróis seguem essas características, ou seja, seus superpoderes foram adquiridos de forma exógena, de fora para dentro, como: a picada de um inseto; uma experiência científica que deu errado; mutações genéticas provocadas por fatores ambientais; ou mesmo o fato de virem de outro planeta. Grande parte deles é caracterizada com personalidade boa e com a determinação de salvar o mundo e, quando não o são, durante a narrativa, passarão por um processo de regeneração. Vale ainda lembrar os casos do Homem de Ferro e do Batman, que apesar de não terem superpoderes são inteligentes e astutos, capazes de criar experimentos que compensam a falta de uma habilidade sobre-humana.

Ao tratar das diferenças entre a literatura culta e a literatura popular, Sodré (1978) afirma que em ambas o herói está presente, porém, na literatura culta celebrava-se o herói da antiguidade ou o gênio superior, enquanto:

A literatura de massa, ao contrário da culta, vai acentuar na "ressurreição" do mito heróico, a onipotência (supra-humana) do personagem. O herói dos romances policiais, de aventuras, etc., tem do herói tradicional, algo de solaridade (a invencibilidade, o triunfo "solar" sobre as sombras), de supra-humanidade (a mística da demiurga e salvação do mundo), de misoginia (a mulher se apresenta freqüentemente como um obstáculo para a ação grandiosa) e de companheirismo heróico (a temática do "duplo"), do amigo que funciona como alter-ego do herói. (p. 83).

Não por acaso, todas as características levantadas por Sodré para tratar do herói da literatura de massas servem também para caracterizar os superheróis do audiovisual. Homem-Aranha, Superman, Hulk, Wolverine e Mercúrio têm poderes supra-humanos. A maioria deles apresenta trajes muito coloridos e ligados ao dia, apenas o Batman, que é associado ao morcego, é um superherói notívago. Todos têm compromisso com a salvação do mundo ou de alguma comunidade/cidade, muitas vezes, devem salvar Nova lorque, por exemplo, que nos filmes é considerada a capital do mundo.

Além de terem que salvar o mundo, é muito comum serem responsáveis por proteger alguma mulher: Lois Lane está sempre em perigo e é resgatada pelo Superman; em vários filmes, o resgate dela coloca em jogo o tempo que ele tem para salvar o mundo. Com o Homem-Aranha e Mary Jane ocorre o mesmo, 
o super-herói inclusive, em um dos filmes, já quis deixar de usar seus poderes para poder se unir a ela e não deixá-la correr nenhum risco. A Mulher-Gato aparece, em alguns filmes, como a antagonista do Batman. O principal conflito do filme $X$-Men: dias de um futuro esquecido ocorre justamente por uma ação da Mística, a personagem feminina de maior destaque no filme. Muitos deles têm alter egos que são pessoas comuns: Homem-Aranha é Peter Parker, Superman é Clark Kent, Batman é Bruce Wayne, Hulk é Robert Bruce Banner.

Assim como os heróis clássicos, os super-heróis integram o imaginário popular contemporâneo e, além de estarem presentes nos quadrinhos e filmes, ganham também versões em brinquedos, jogos, camisas, jogos eletrônicos e uma infinidade de outros produtos. Nesse sentido, a partir do que apresenta Jenkins (2009) como convergência das mídias, é possível inferir que os espectadores do audiovisual ganham status de consumidores, pois não querem apenas ver o filme de seu super-herói favorito, é preciso ter acesso aos produtos que fazem referência àquele herói, pois assim, tem-se a sensação de maior proximidade com o personagem. É como se os quadrinhos ganhassem o cinema, quando se produz um filme inspirado nos super-heróis das HQs, e o cinema ganhasse todo o resto da indústria cultural ou consumo de massas.

É evidente que, no cinema e na indústria cultural como um todo, os heróis e super-heróis não têm o compromisso com a realidade, por isso, mesmo os considerados mortais são capazes de aventuras e ações inimagináveis na realidade e conseguem sair ilesos de suas aventuras. É a partir dessa ideia do herói como alguém quase imortal e completamente invencível que Kellner (2001) explica, por exemplo, o sucesso mundial do personagem Rambo, vivido pelo ator Syvester Stallone na década de 1980:

Em filmes, a ideologia é transmitida por imagens, figuras, cenas, códigos genéricos e pela narrativa como um todo. A posição da câmara e da iluminação em Rambo ajuda a enquadrar Syvester Stallone como um herói mítico; uma grande abundância de ângulos baixos da câmara apresenta Rambo como um guerreiro mítico, enquanto os frequentes closes o apresentam como um ser humano maior do que na vida real. O foco em seus bíceps luzidios, no seu corpo escultural e no físico poderoso apresenta-o como um símbolo sexual masculino, como um emblema de virilidade, que provoca a admiração das mulheres pela força masculina e talvez uma fascinação homoerótica pelo guerreiro masculino. As tomadas de cena em travelling e a câmera lenta codificam Rambo como uma força da natureza, que percorre a selva sem esforço, enquanto a música triunfante codifica seus feitos como super-heroicos. Sua regeneração como super-herói é apresentada em tomadas nas quais ele se projeta magicamente fora da água, purificado e potente, dignificado para vingar e triunfar. (p. 93).

É interessante notar que os heróis e super-heróis escolhidos pelos jovens vivenciam, também, nas narrativas apresentadas, experiências de purificação e 
de regeneração. Wolverine, por exemplo, em X-Men: dias de um futuro esquecido, é um homem fisicamente tão forte quanto Rambo e considerado tão explosivo quanto ele, por isso, precisa aprender a controlar sua raiva para vencer as batalhas que aparecem. Em uma das cenas do filme, ele cai no mar e é resgatado com uma aparência mais serena e lúcida, como se a água o tivesse purificado.

É evidente também a força física dos atores Jeremy Renner (João, de João e Maria: caçadores de bruxas) e Vin Diesel (o Kaulder, d'O último caçador de bruxas), que, assim como Rambo, no decorrer das narrativas em que aparecem, vão sendo elevados à categoria de super-heróis pela ambientação do filme, a trilha sonora, a aproximação com a morte, o movimento de câmeras e outros elementos fílmicos que descrevem a transformação lenta e progressiva pela qual eles passam.

Os super-heróis que não têm aparência física forte, como Mercúrio, Homem-Aranha, professor Xavier e outros, apresentam superpoderes que compensam a força física e, por isso, conquistam a admiração dos espectadores. O mesmo ocorre com Batman e o Homem de Ferro, que compensam a força com a inteligência. Isso foi observado nas argumentações de alguns alunos, ao serem perguntados especificamente sobre as personagens de $X$-Men: "De todas as personagens de $X$-Men: dias de um futuro esquecido, de qual você escolheria os poderes e as fraquezas? Por quê?":

Eu escolheria os poderes e fraquezas do Mercúrio porque são vários poderes e uma só fraqueza, que pode ser controlada se eu quiser, se for paciente. (Olaf).

O professor Xavier, que fez esta escola, porque o poder dele é incrível! E eu não ligo de ter a fraqueza dele, porque se ele não tivesse passado por tudo isso que passou ele não conseguiria ficar bem com os humanos e não conseguiria lutar pelos direitos deles, etc. (He-Man).

Eu escolheria o Mercúrio e a fraqueza do Wolverine, porque pra mim é fácil controlar as emoções. (Thor).

As repostas apresentadas pelos jovens pesquisados indicam que para eles, é possível trocar a força física pela intelectual ou controle das emoções, visto que Mercúrio tem o poder de movimentação rápida, o que pode causar uma sensação de monotonia, pois vê o mundo em câmera lenta, mas, diante de seu poder, segundo a argumentação de um dos alunos, é possível controlar sua fraqueza. O professor Xavier é altamente inteligente e capaz de controlar as mentes dos outros, mas não tem o movimento das pernas, porém, para eles, sua força intelectual é capaz de superar sua deficiência física; enquanto Wolverine é forte fisicamente, mas extremamente fraco emocionalmente, o que para os 
alunos, assim como mostrado no filme, pode ser superado. Nesse sentido, esses jovens, em suas respostas, argumentam ser possível compensar a força física com a força intelectual ou emocional e vice-versa. No entanto, percebem que a força excepcional continua em evidência, ou seja, que é uma característica presente nos heróis masculinos dos cinemas assim como na literatura de massas. Ao tratar do cinema nos anos 1940 e 1950, Louro (2000, p. 238) afirma:

O cinema hollywoodiano era, fundamentalmente, construído a partir de uma ótica masculina e heterossexual. Essa era também uma ótica branca e de classe média. Assim como ocorria na ciência, nas doutrinas religiosas ou na educação, essa ótica masculina, branca, heterossexual (e usualmente judaico-cristã) pretendia-se universal, era ela que propunha a estética e a ética que de fato contavam. Como resultado de um jogo de poder nem sempre claramente enunciado, as "outras" identidades culturais eram tornadas invisíveis ou eram representadas sob formas subordinadas ou marginalizadas.

A afirmativa de Louro (2000) remete ainda ao que Sodré (1978) apresenta como caracterização dos heróis da literatura de massa e, comprovado a partir de exemplos apresentados também nos quadrinhos e no audiovisual, ou seja, existe, ainda, uma forte primazia masculina na produção de cinema e de HQs por isso, talvez, a misoginia ainda prevaleça.

Outros nomes escolhidos pelos jovens pesquisados, como Olaf, Harry Potter ou Troll, também, de certa forma, heróis, pois são responsáveis por resolverem alguma trama nas narrativas. Olaf, no filme Frozen: uma aventura congelante, é um boneco de neve que ganha vida, uma espécie de herói, pois além de sua transformação de ser inanimado a quase humano, foi eleito pelas irmãs Ana e Elsa como uma espécie de cuidador delas, em quem depositaram confiança, visto que elas não precisam de um homem forte para resolver seus conflitos. Ele, então, cumpre o papel do príncipe dos contos de fadas que, de uma maneira mais sutil, orienta as irmãs, é também um dos responsáveis por cenas mais descontraídas do filme, tirando um pouco o peso emocional que a narrativa trata.

Nesse sentido, é possível dizer que os meninos pesquisados sentem-se confortáveis ao serem representados como heróis nos filmes que veem, e ao assumirem essas representações, eles entendem que estão representados nos cinemas como fortes (fisicamente, intelectualmente e/ou emocionalmente) e que são imbatíveis, portanto, apesar de poderem questionar essa identidade masculina, e isso, algumas vezes, ocorre, como mencionado por Louro (2000), é uma identidade segura, construída ao longo de anos e que atende ao grande público. A partir disso, vale questionar: e as identidades femininas traduzidas 
pelas imagens do cinema têm o mesmo eco que a identidade masculina do herói ou super-herói representa para os meninos?

As meninas desta pesquisa, que responderam à atividade de escolha dos nomes, optaram pela mocinha sofredora (Hazel Grace, Bella I, Bela II, Claire e outras), pela heroína (Lince Negra), pela anti-heroína (Malévola) ou por nenhuma delas, recorrendo a cantoras, atrizes ou mesmo a personagens masculinas. A partir dessas evidências, é possível inferir que o cinema vem desconstruindo o padrão de identidade feminino que foi sendo construído ao longo de sua história, mas ainda não chegou a um estereótipo do feminino que conquistasse inteiramente o grande público. Ao mesmo tempo, algumas características femininas, como a leitura mais emocional da trama, são mantidas, mudando apenas os graus de emotividade das personagens retratadas. Segundo Louro $(2008,2013)$, ao analisar as representações de gênero no cinema a partir dos anos 1950, é possível notar transformações nas últimas décadas. Este é um fato importante, pois, segundo a autora, havia predominantemente dois papéis femininos que se contrapunham: "a mulher respeitável e a prostituta" (Louro, 2013, p. 175), que serviam de escada para o personagem masculino que era o protagonista de fato.

Em outro artigo, a autora expõe mais detalhadamente questões ligadas às diversas mudanças pelas quais passou o personagem homossexual nos filmes, que vão do repulsivo, chegando ao cômico e adquirindo papel central em algumas tramas dramáticas. Porém, ao falar das personagens femininas, nos anos 1950, ela afirma:

Num tempo de pós-guerra, parecia necessário, de algum modo, deter ou reverter o avanço feminino que fora possibilitado pelo longo conflito. $O$ cinema ajudaria a promover a "volta ao lar" e a recomposição da estrutura familiar tradicional. Roteiros de inúmeras comédias, romances ou dramas passavam a tratar daquele que se colocava como o novo dilema feminino: a escolha entre a família (casamento e filhos) ou a carreira profissional. Um happy end recompensava as mulheres que escolhiam certo, isto é, o lar, enquanto que as outras, muitas vezes representadas como "masculinizadas", duras e amargas, terminavam sós e infelizes. (Louro, 2008, p. 83).

Nos filmes visualizados pelos alunos, a questão não perpassa o casamento, nem nas qualidades das personagens, não há mocinhas lineares, por exemplo, mas, em muitos deles, apesar de diferentes estereótipos as mulheres estão diante de grandes amores e a escolha entre o amor e a guerra. Exemplos disso estão em Jogos vorazes e Malévola, além disso, a personagem Mística, de $X$-Men, parece ter de escolher entre o amor de Xavier e de Magneto, e tomar essa decisão é também garantia de tomar partido de um dos lados do 
conflito posto para a humanidade. Vale ressaltar que as personagens femininas retratadas nos filmes vistos, apesar de inúmeras diferenças, agem muito mais tomadas por decisões emocionais do que racionais, fazendo o grande público crer que essa é uma característica feminina, conforme citado anteriormente.

Outro fato que chamou atenção foi quando ao desenvolver uma atividade em que a heroína e personagem central da narrativa é uma jovem, uma das meninas recriou o figuro dessa personagem inspirando-se no Superman, conforme apresentado anteriormente: "Os looks são inspirados no Superman, mas é um look mais para jantares, reuniões, etc. Eu escolhi me inspirar nele, pois sempre que falam em heróis, eu me lembro dele." (Lince Negra). A resposta da aluna à atividade torna evidente o poder do super-herói masculino não só no imaginário dos meninos, mas também no imaginário feminino, visto que, segundo Eco (1970, p. 246): "O herói provido de poderes superiores aos do homem comum é uma constante da imaginação popular, de Hércules a Sigfrid, de Roldão a Pantagruel e até a Peter Pan." Ou seja, esses heróis masculinos estão nas narrativas orais, na literatura, nos quadrinhos e foram para o cinema, é um discurso de séculos esse de que para ser herói, primeiro é preciso ser do gênero masculino. Mesmo que o cinema, as artes e a cultura de massas em geral já apresentem outras possibilidades na criação do herói, o discurso é forte e como vem de longe, não dá para mudá-lo em poucas décadas. É preciso persistir em construções de outros tipos de personagens, mas é preciso também a aceitação do espectador para o novo.

O fato de algumas jovens optarem por outros nomes que não de personagens do cinema, pode ser porque, apesar de todas as tentativas, as heroínas fílmicas não as representem de fato, visto que as personagens são apresentadas mais humanas, menos poderosas e ainda dependentes das tomadas de decisões masculinas, mesmo que em menor grau. Se comparadas ao universo das personagens masculinas, veremos que as personagens têm fraquezas mais difíceis de resolver ao longo da narrativa. Há uma diferença na representação do feminino e do masculino no cinema que, mesmo com todas as tentativas da indústria cultural, ainda não foi resolvida, talvez seja por esse fato que esta vem tentando vários padrões para as personagens femininas ao longo das últimas décadas, enquanto grande parte das personagens masculinas segue um mesmo padrão que destaca força e inteligência, além da impulsividade. Este pode ser um apontamento de que o público também é capaz de mudar o modo como a indústria do entretenimento age e produz seus artefatos culturais. 


\title{
A necessidade da fantasia: a mágica como solução de conflitos
}

\author{
A arte é necessária para que o homem se torne capaz de \\ conhecer e mudar o mundo. Mas a arte também é necessária \\ em virtude da magia que lhe é inerente. (Fischer, 1959, p. 20).
}

A epígrafe que abre este capítulo, do filósofo austríaco Ernst Fischer, apresenta as expressões artísticas como tendo características que são paradoxais e ao mesmo tempo complementares. Segundo o autor, a arte pode transformar o mundo quando faz pensar sobre ele, levando os espectadores a agirem pela transformação e pode também apresentar-se como magia, propondo o entretenimento e a fruição, levando o espectador à contemplação. Nessa mesma perspectiva, o poeta maranhense Ferreira Goulart teve uma de suas frases imortalizada e repetida por ele inúmeras vezes em entrevistas e palestras: "A arte existe porque a vida não basta."

Nesse sentido, é possível entender o cinema numa perspectiva estética que serve para refletir sobre o mundo, mas também para desligar-se do mundo e criar uma fantasia em torno da narrativa.

Ao tratar da linguagem do cinema, Carrière (2014, p. 81) enfatiza:

No cinema, qualquer atividade é familiar e corriqueira. Os personagens sabem nadar, ler, dançar, cavalgar e falar outros idiomas. Sempre conseguem um quarto de hotel, e, quando chamam o mensageiro, ele aparece de imediato. Os carros pegam na primeira tentativa e a cavalaria (quase) sempre chega bem na hora. [...] E quando uma jovem com aparência bem intelectual é tocada pelo sopro do amor, ocorre um verdadeiro milagre ótico: ela repentinamente deixa de usar óculos, sem qualquer efeito aparente sobre sua habilidade de ler e escrever.

A magia do cinema está também nessas repetições, clichês e nas cenas em que o inusitado só acontece quando está previsto para acontecer. Dessa forma, quando algumas dessas repetições não acontecem, podem causar algum estranhamento no espectador.

Os filmes assistidos pelos jovens, nas oficinas desenvolvidas no âmbito desta pesquisa, em sua maioria, são classificados nos gêneros fantasia ou ficção científica e o fato de terem ocupado os primeiros lugares das listas das maiores bilheterias sugere que o público desses filmes, em sua maioria jovens, apreciam vivenciar experiências bastante diferentes de suas realidades cotidianas. Isso ocorreu também com os jovens que participaram das oficinas. 
Ao mesmo tempo, aparentemente afastando-se de temáticas mágicas e da fantasia, ao criarem seu próprio filme, esses jovens optaram por um tema bastante ligado ao seu cotidiano, o bullying, e ambientaram esse tema no espaço escolar, onde certamente vivenciam situações desse tipo, porém, trouxeram ao problema levantado uma solução fantasiosa (conforme será apresentado a seguir). Dessa forma, eles formulam o problema ancorados na realidade e, conforme Fischer (1959, p. 20), incitam a ação, mas a forma que escolhem para enfrentá-lo parece compartilhar do pressuposto de que "um resíduo mágico na arte não pode ser inteiramente eliminado [...]."

É importante, ainda, destacar que, dos quatro primeiros filmes de maior bilheteria em 2014, listados pela Ancine - com jovens como protagonistas e assistidos pelos participantes da pesquisa -, apenas um deles era drama ( $A$ culpa é das estrelas). Os demais foram classificados como fantasia ou ficção científica. Outros que foram selecionados inicialmente para serem exibidos durante a pesquisa, mas não foram visualizados - Capitão América 2, 0 espetacular Homem-Aranha 2, 0 Hobbit: a batalha dos cinco exércitos e Guardiães da galáxia - foram descartados no decorrer das atividades, por tratarem de fantasia e ficção científica, além de serem filmes de super-heróis, categoria já bastante discutida a partir dos filmes $X$-Men: dias de um futuro esquecido e Jogos vorazes: a esperança - parte 1. Porém, ao ser pedido aos alunos que escolhessem os filmes aos quais gostariam de assistir, esses gêneros se mantiveram predominantes, a partir dos títulos: As crônicas de Nárnia: o Leão, a Feiticeira e o Guarda-Roupa, João e Maria: caçadores de bruxas e Jurassic World: o mundo dos dinossauros, evidenciando o apreço deles pelas narrativas de fantasia/magia.

Este capítulo está subdividido em duas partes: na primeira analiso a percepção dos sujeitos pesquisados em relação aos filmes de grandes bilheterias e também aos filmes brasileiros visualizados; na segunda parte, analiso o processo de produção do curta-metragem realizado por eles.

\section{1}

\section{Dois filmes, duas concepções, dois olhares}

No início das atividades da pesquisa de campo, exibi um curta-metragem brasileiro para os alunos. A ideia inicial era que eles visualizassem o filme em 
nosso primeiro encontro para começarmos a discussão em torno da temática, porém, a exibição ocorreu em nosso terceiro encontro.

O filme exibido chama-se Confusões de adolescentes (2012), um curtametragem brasileiro de aproximadamente $25 \mathrm{~min}$, disponível no YouTube. O canal que hospeda o filme nessa rede social traz a seguinte sinopse:

Confusões de adolescentes é um curta-metragem brasileiro de comédia que narra as confusões presentes dentro de um grupo de adolescentes de forma leve e divertida. Fala sobre o amor e os entremeios causados pela conturbada fase adolescente. $^{43}$

Além da sinopse, há vários comentários de espectadores que interagem com um dos atores principais e este reponde aos comentários. Somente no site em que está hospedado, o filme teve 691.954 visualizações até o início de 2016.

É importante destacar que o nome do filme é uma referência a outro audiovisual brasileiro, produzido no início da década de 1990, chamado Confissões de adolescente (Daniel Filho e Cris D’Amato, 2014), uma série de TV baseada em um livro escrito pela atriz Maria Mariana, que foi adaptado para o teatro e, mais recentemente, foi lançado um filme baseado nos produtos anteriores. No material produzido por Maria Mariana há relatos sobre uso de drogas, aborto e outros temas, que o filme Confusões de adolescentes descarta completamente.

O curta-metragem apresenta uma trama leve, que gira em torno de dois casais de adolescentes vivendo suas primeiras paixões; tem como cenário uma cidade de praia e não há muitos adultos no enredo, a única personagem adulta com destaque na narrativa não está no núcleo principal. Essa trama simples, sem grandes conflitos e recheada de cenas descontraídas, facilmente pode remeter-se a filmes hollywoodianos que têm como cenário as férias de verão de adolescentes, cuja narrativa gira em torno de namoros, festas e eventuais desentendimentos entre amigos.

No quadro a seguir, são apresentadas as principais personagens do filme Confusões de adolescentes e suas características mais marcantes:

\footnotetext{
${ }^{43}$ Disponível em: <https://www.youtube.com/watch?v=An6fR8EBlp8>. Acesso em: 23 fev. 2016.
} 


\begin{tabular}{|l|l|}
\hline \multicolumn{1}{|c|}{ Personagens } & \multicolumn{1}{c|}{ Características } \\
\hline Pedro Henrique (PH) & $\begin{array}{l}\text { Jovem, descolado, tem vários amigos, é bonito e líder da } \\
\text { turma, é surfista e esportista. }\end{array}$ \\
\hline Ruy & $\begin{array}{l}\text { Amigo de PH, jovem tímido, gosta muito de jogos e é } \\
\text { considerado nerd. }\end{array}$ \\
\hline Tamara & \begin{tabular}{l} 
Irmã de Pedro. \\
\hline Maria
\end{tabular} \\
\hline Tati & $\begin{array}{l}\text { Amota nova que chega ao condomínio e desperta o amor } \\
\text { Amiga dedro, apaixonada por ele e vai tramar situações } \\
\text { para conquistá-lo. }\end{array}$ \\
\hline Helena & $\begin{array}{l}\text { E uma menina que fará o papel de cupido e conselheira de } \\
\text { Tati e de Tamara. }\end{array}$ \\
\hline Madrasta da Helena & $\begin{array}{l}\text { A única adulta da narrativa com papel de destaque. Não } \\
\text { está no núcleo principal, que é o dos adolescentes, } \\
\text { interage apenas com Helena. }\end{array}$ \\
\hline
\end{tabular}

Quadro 10 - As principais personagens de Confusões de adolescentes

Fonte: Elaboração própria

A história começa apresentando Pedro e Tamara, dois irmãos adolescentes que, logo no início da narrativa, conhecem Maria, a filha da namorada do pai deles. Pedro logo se interessa por Maria. Tati, que é amiga de infância dos irmãos, fica chateada, pois gosta de Pedro, mas ele só a vê como uma amiga. Pedro conversa com Ruy por uma rede social e conta da chegada de Maria. Tati está triste e aparece uma menina de aproximadamente 8 anos que dá conselhos amorosos a ela. A menina é Helena, que está se escondendo da madrasta. A narrativa continua com encontros e desencontros, cenas na praia, no salão de beleza e na casa dos irmãos. O final feliz é garantido e a narrativa termina tão leve quanto começou.

O filme foi muito bem recebido pelos jovens pesquisados, nenhum deles disse não ter gostado. Muitos anotaram o endereço do filme no YouTube para revê-lo em casa e mostrar para os amigos; uma das turmas pediu para rever o final, pois havia sobrado tempo para isso. Um dos jovens, no encontro seguinte, comentou que gostou muito da narrativa e tinha revisto em casa.

Como atividade prática, pedi a eles que respondessem: "Qual é o personagem do filme que você destacaria? Por quê?" 27 jovens responderam a esta atividade, sendo 12 meninos e 15 meninas. A personagem mais votada foi Pedro (ou PH), que teve 10 votos, em seguida a menina Helena, com 8 votos, Ruy obteve 4 votos, Tati 3 votos, Maria um voto e todas as meninas um voto. As justificativas para a escolha de determinada personagem ficaram em torno da função que ela exerce na narrativa ou das características da personagem, uma espécie de projeção/identificação com o herói.

No caso da justificativa em torno da narrativa, podemos destacar a escolha por Helena, como mostram algumas respostas: 
A Helena, porque ajudou as meninas. (Alice II).

A Helena, porque ela resolve o caso das meninas e ela aparece mais. (Owen).

Helena, porque ela é fofa e dá conselhos. (Aruna).

A Helena, porque ela entende de relacionamento. (Lola).

Ao ler as repostas dos jovens em relação à Helena, é possível notar que ela é considerada peça-central para o desenvolvimento da narrativa, por isso, foi considerada uma personagem de destaque. Ela se destaca dentro da trama justamente por ter o papel da conselheira, daquela que impulsiona as demais personagens, levando-as a agir.

No caso da escolha por Pedro, a justificativa fica em torno das características da personagem, ou seja, estão mais ligadas ao processo de projeção e identificação entre personagem e espectador:

$\mathrm{O} \mathrm{PH}$, porque o estilo dele é bem legal e pegador. (Não identificado).

Eu quero ser o $\mathrm{PH}$ para pedir para fazer pipoca de micro-ondas. (Troll).

$\mathrm{PH}$, porque eu quero ser igual a ele. (Cristiano Ronaldo).

$\mathrm{PH}$, para beijar a Tati. (Augustus).

Eu gostei do PH, porque ele é bonito. (Malévola).

As respostas dos alunos mostram que muitos deles se colocaram no lugar de $\mathrm{PH}$, personagem provavelmente criada para isso: ser aquele que muitos gostariam de ser, pois é bonito, ou seja, segue os padrões de beleza estabelecidos pela mídia, tem atitude e luta para realizar seus desejos e vontades; sua personagem faz oposição ao amigo Ruy, que é calado, tímido e não confia em si mesmo, mas também atinge seus objetivos, no entanto, está sempre à sombra do amigo. O processo de projeção e identificação, conforme Freitas (2002), está relacionado à capacidade do espectador de se colocar no lugar do herói. As respostas dadas pelos jovens para a escolha de $\mathrm{PH}$ parecem evidenciar esse processo.

O fato de o filme ser estética e narrativamente próximo aos filmes estadunidenses, aos quais os pesquisados estão acostumados a assistir, cria uma rápida harmonia com o que está sendo visualizado, por isso a opinião de que o filme é bom aparece rapidamente nas falas desses sujeitos.

Já ao final da pesquisa de campo, em um dos últimos encontros, sugeri ao grupo que víssemos outro filme de nacionalidade brasileira. Essa ideia surgiu, pois em vários momentos da pesquisa, quando falavam de filmes brasileiros, 
eles sempre tinham um tom de deboche ou se referiam a estes de maneira pejorativa. A jovem Malévola, em um dos encontros disse: "Ô professora, por que a maioria dos filmes legal vem de países ricos? Já vou deixar claro, hein, eu não gosto do Brasil!"

A ideia de assistir com eles a outro filme brasileiro era para ter mais elementos para avaliar se eles não gostavam de filmes produzidos aqui ou se eles os desconheciam, posto que são filmes, como visto no capítulo 6 , que enfrentam problemas com distribuição e, portanto, muitas vezes, não atingem o grande público.

O filme escolhido para a exibição na oficina foi As melhores coisas do mundo, de Laís Bodansky, que é veiculado com a seguinte sinopse:

\begin{abstract}
Mano tem 15 anos, adora tocar guitarra, sair com amigos e andar de bike. Um acontecimento na família faz com que ele perceba que virar adulto não é brincadeira. O bullying na escola, a primeira transa, o relacionamento em casa, as inseguranças, os preconceitos e a descoberta do amor transformam a adolescência numa travessia nada simples. Com roteiro de Luiz Bolognesi, direção de Laís Bodansky, com produção da Gullane, o filme é livremente inspirado na série de livros "Mano", escritos por Gilberto Dimenstein e Heloisa Prieto. (Contracapa do DVD).
\end{abstract}

Lançado em abril de 2010, tem em seu elenco vários atores vinculados às produções da Rede Globo de Televisão, como: Caio Blat, Paulo Vilhena, Denise Fraga, Zé Carlos Machado, Gustavo Machado, Fiuk, Francisco Miguez, entre outros, ou seja, são atores já conhecidos do grande público.

Na narrativa, Mano (Francisco Miguez) passa por inúmeros problemas e descobertas: vê o pai separar-se da mãe e começar a namorar um aluno, acompanha as crises de ciúmes do irmão com a namorada, é acusado de cometer bullying, sofre bullying, vive sua primeira experiência sexual, lança uma chapa para o grêmio da escola, briga com sua melhor amiga e percebe-se perdido diante das escolhas que precisa fazer. A trama se passa quase que integralmente em uma escola de classe média paulistana, mas há cenas externas nas ruas da cidade de São Paulo, no ônibus, na casa de Mano, na casa do pai de Mano e na casa do professor de guitarra.

Diferente do curta-metragem Confusões de adolescentes, nesse filme a trama aborda problemas graves da vida familiar e social e há muitos adultos. Mano vive conflitos mais sérios do que ter de escolher entre uma paixão e outra, a vida familiar dele é cheia de situações complexas que precisam ser resolvidas e, na escola, as relações também são muito conflitantes.

Laís Bodanski dirigiu filmes como Bicho de sete cabeças (2000), Chega de saudades (2007), O mundo invisível (2012), Uma história de amor e fúria (2013), 
Mulheres olímpicas (2013) e Como nossos pais (2017). Ela é uma das diretoras mais respeitadas no cinema brasileiro da atualidade e, além de direção e roteiro, faz com Luiz Bolognesi um trabalho com cinema itinerante, na perspectiva de formação de público para o audiovisual. Desde 2004, ela leva o Cine Tela Brasil para vários municípios, apresentando filmes nacionais e infantis para mais de 230 mil espectadores e a partir de 2007, começou a dar oficinas de produção audiovisual em comunidades carentes.

Tendo começado sua carreira com documentários, seus filmes costumam mexer com o espectador, pois mesmo ficcionais, partem de uma realidade possível e discutem a fundo inúmeros problemas. Seus filmes parecem ter um compromisso com a discussão de questões complexas.

O filme visualizado pelos sujeitos desta pesquisa não tem cenas óbvias e, em vários momentos, trabalha com zonas de sombra (Carrière, 2014), ou seja, deixa de mostrar algo e passa para o espectador a ação de imaginar determinado cenário ou situação, pois alguns cortes, luzes diferentes e sons propõem cenas que são somente sugeridas e precisam ser imaginadas. Isso ocorre, por exemplo, quando Pedro (interpretado pelo ator Fiuk), irmão de Mano, tenta suicídio em um quarto de hotel, tomando um determinado medicamento. Vê-se na composição da cena, o quarto, na penumbra, o ator, com forte expressão corporal de sofrimento, móveis, o vidro com os compridos entre outros objetos e há um corte, após o qual se vê uma ambulância chegando. A cena seguinte traz a família reunida num quarto de hospital, conversando com Pedro, que se encontra no leito. O tratamento do tema não é óbvio e nem apela para simplificações.

Durante a exibição do filme, escutei várias vezes os jovens dizerem: "Tem coisas deste filme que a gente já viu aqui na escola." Uma das cenas em que este comentário ocorreu, foi quando uma aluna do colégio de Mano teve uma foto nua divulgada entre os grupos de WhatsApp da escola. Em uma cena em que Mano ajuda a mãe a limpar a cozinha, outra jovem comentou: "Ah! Faço isso lá em casa também, mas a maioria das vezes é minha mãe." (Malévola).

Ao final da exibição, perguntados se haviam gostado do que assistiram, uma das jovens responde: "Gostei. Ele é um filme realista, diferente de outros que vimos." (Lince Negra). Os demais não se manifestaram, mas a fala dessa aluna é importante, pois evidencia que ela percebeu a diferença desse filme para os demais; ao usar a palavra "realista", ela parece querer dizer que o filme tem um compromisso maior com a realidade, ou com a verdade. 
É possível, ainda, analisar a fala dessa jovem à luz de uma afirmação de Carrière (2014, p. 82): “O cinema, que tão frequentemente se aventura pelo irreal, constantemente renuncia a uma realidade que considera difícil demais de ser engolida." Nesse filme, a diretora optou, em vários momentos, por abordar esse tipo de realidade e isso causou estranhamento em muitos dos jovens pesquisados, acostumados com filmes em que "certas mentiras resultam de omissão" (Carrière, 2014, p. 80).

Vale ressaltar que após todas as exibições de filmes, eu sempre perguntava se eles haviam gostado, em todas as outras vezes, as respostas foram efusivas e, em grande parte das vezes, os filmes eram classificados por todos como muito bons. Neste filme, especificamente, vi que muitos não gostaram ou ficaram mais incomodados com a narrativa visualizada. Supus que, diferente dos demais, este filme necessitava de mais tempo para ser elaborado por eles, talvez por ser um dos poucos filmes visualizados que estavam mais próximo do cotidiano deles.

Após a exibição do filme e de alguns comentários sobre ele, pedi que respondessem por escrito quatro questões (Apêndice I):

1) Você gostou do filme? Por quê?

2) Destaque uma cena que você tenha gostado mais. Justifique a escolha.

3) Em relação aos filmes norte-americanos, o que você percebe de diferença? Isso é bom ou ruim? Por quê?

4) Você recomendaria este filme? Por quê?

Participaram dessa atividade 33 jovens. Em relação à primeira questão, 20 responderam que gostaram do filme, 9 que não gostaram e 4 que gostaram mais ou menos. Em relação à quarta questão, 22 responderam que recomendariam, 3 responderam que talvez recomendassem, e 8 que não.

É importante frisar que as justificativas para essas duas respostas são bastante parecidas. Aqueles que gostaram e recomendariam o filme desenvolveram suas justificativas levando em conta o enredo e a temática apresentada. Os que não gostaram do filme e/ou não recomendaram, tomaram essa decisão em função das questões técnicas ou do gênero do filme, além de alguns que reforçaram não gostar de filmes brasileiros.

Eis algumas respostas dadas à primeira questão:

Não gostei muito, porque algumas coisas estavam na cara. (Emma Watson).

Gostei. Porque o filme foi muito bom e porque o Mano foi muito corajoso de não ter ficado com vergonha do próprio pai. (Hazel Grace). 
Gostei. Porque o filme passou uma mensagem muito legal sobre o preconceito e porque é parecido com a realidade dos jovens. (Owen).

Gostei. Porque parece com a nossa realidade. (Claire).

Gostei da forma como a história foi contada. (Homem de Ferro).

Não. Porque não gosto de filme brasileiro, só gosto de filme estrangeiro, esse filme é péssimo e o áudio é horrível. (He-man).

Não, porque o filme é brasileiro e os filmes brasileiros não são muito editados. (Luna).

Os jovens que gostaram do filme destacaram o fato de ele estar próximo da realidade deles e de ser uma narrativa que passa uma mensagem, os que não gostaram destacaram o fato de não apresentar suspense e as cenas serem óbvias ou "verdadeiras" demais ou, ainda, criticam as questões técnicas, como áudio e edição.

As respostas dadas à questão 4 mantêm um escopo muito próximo das respostas dadas à questão 1 . Nesse sentido, é possível perceber uma coerência em relação ao gosto e à recomendação dos filmes. Há, por exemplo, jovens como a de codinome Emma Watson, que não gostou do filme, mas na questão 4 respondeu: "Eu recomendaria, pois talvez a pessoa goste desse tipo de filme." Há outras respostas que a recomendação para assistir ou não está mais diretamente relacionada à impressão que os pesquisados tiveram do filme e suas justificativas seguiram essa lógica:

Sim, porque ele parece com a nossa realidade e é bem legal. (Claire).

Talvez, pois só recomendo filme que eu gosto muito. (Aline Barros).

Sim, pois ele é bom e não é americano e é bem realista. (Lince Negra).

Sim. Pois a história é real e a fotografia é muito bem feita. (Mercúrio).

Sim, o filme é ruim, mas a mensagem que o filme traz é boa. (Wolverine).

Não e sim. Não porque não gostei e sim por que há quem esteja na mesma situação que o filme. (Malévola).

A partir das respostas dadas pelos sujeitos desta pesquisa, fica evidente que alguns recomendam o filme por ele tratar da realidade, destacando assim a mensagem narrativa; poucos jovens destacam as questões técnicas para recomendá-lo e outros acreditam que o filme deve ser visto apenas por quem está vivenciando as situações narradas ali.

Em relação à questão 3, que era para eles escolherem uma cena do filme de que mais gostaram, quatro cenas são recorrentes, por ordem de maior 
escolha: o beijo entre a Carol e o Mano (uma das cenas finais), a tentativa de suicídio de Pedro, a revelação da homossexualidade do pai de Mano e o abaixoassinado na escola. É interessante notar que a que é mais mencionada é, talvez, a cena mais leve do filme, pois é a cena final, em que os conflitos temporariamente se resolvem, em uma espécie de happy end.

As outras três cenas mais citadas são aquelas em que atitudes são tomadas por algumas das personagens e que podem mudar o rumo da narrativa, duas delas (quando o pai conta aos filhos que está namorando outro homem e a tentativa de suicídio de Pedro) são de ordem mais pessoal e, apesar do tom realista, os filhos, ao final da narrativa, se entendem com o pai e Pedro consegue se salvar da morte, o que levou ao comentário de uma das jovens no momento da visualização do filme: "Não falei, não falei... É igual novela: gente esses caras não morrem não!!!" (Malévola).

A última cena com maior número de menções é a que narra uma atitude social e política de Mano, que faz um abaixo-assinado na escola para evitar a saída de um professor; vários participantes da pesquisa entenderam que a atitude do jovem foi muito justa e corajosa. Das três cenas, esta última altera a narrativa, mas para dissolver um conflito, enquanto as duas anteriores são criações de conflitos que, ao longo da história, se resolvem, talvez por isso uma das alunas, ao responder por que não gostou do filme, justifica afirmando que "algumas coisas estavam na cara", ou seja, que o conflito seria posteriormente resolvido.

A terceira questão respondida pelos jovens trata das diferenças percebidas entre o filme brasileiro e os filmes estadunidenses vistos anteriormente. Responderam essa questão, 24 jovens e todos apontaram alguma diferença entre os filmes visualizados antes e o filme As melhores coisas do mundo. Ao analisar as justificativas para a percepção das diferenças que eles evidenciaram, cataloguei-as em quatro grupos: 12 respondentes evidenciaram diferenças técnicas, 7 apontaram questões de gosto, 3 destacaram a diferença na narrativa e 2 evidenciaram técnica e gosto. Eis duas respostas para cada um dos grupos:

Os filmes internacionais são produções mais caras e trabalhadas. (Mercúrio, grupo 1).

O som deste é ruim, porque o som parece meio velho. (Claire, grupo 1).

Os filmes norte-americanos são melhores, porque têm mais aventura. Bom, porque fica melhor de ver. (Lúcia, grupo 2).

Eu prefiro os americanos porque têm comédia. (Bela I, grupo 2). 
A diferença é que este é mais realista. É bom! (Lince Negra, grupo 3).

Eu percebo de diferente o jeito dos personagens. (Hazel Grace, grupo 3).

Os filmes norte-americanos são melhores mil vezes que esse filme, o áudio é bom, a qualidade é boa. Já o brasileiro, muito ruim, muito sem graça. (He-man, grupo 4).

Penso que cada lugar tem um estilo de filme e isso é bom. (Bela II, grupo 4).

A visualização deste filme proporcionou aos alunos o rompimento com o contato apenas com um tipo de narrativa fílmica, possibilitando a ampliação do olhar deles para o audiovisual. Nesse sentido, comungo com Ramos e Teixeira (2010), que ao tratar da obra de Bergala, sugerem que o trabalho com cinema na escola:

É algo que causa estranheza, porque rompe com a cultura escolar instituída na qual o cinema, quando nela está, costuma ser didatizado e instrumentalizado como mero recurso metodológico, entre outras de suas restritas formas de habitar os territórios escolares. Contrariando essa lógica, o cinema pensado como alteridade interroga o já visto, remove o instituído, desloca os olhares, inventa ideias, possibilidades. Outros enredos. Novas linguagens. Luminosidades tantas (Ramos \& Teixeira, 2010, p. 7-8).

A partir da concepção de que a pesquisa desenvolvida com esses jovens teve um caráter interventivo, ou seja, pode levá-los a ter um olhar mais atento para os filmes que assistem e proporcionar a eles uma experiência estética diferente, penso que a visualização desse filme, permitiu que eles tivessem esse novo olhar para o audiovisual, ampliando, dessa forma, a ideia de cinema que tinham e propiciando a eles um olhar mais abrangente acerca das narrativas nacionais, muito pouco conhecida deles.

O fato de 24 dos 33 sujeitos desta pesquisa manifestarem a percepção das diferenças entre o filme brasileiro e os filmes estadunidenses e de alguns deles não estabelecerem uma relação de preferência entre um e outro, aponta que há possibilidades de um trabalho pedagógico produtivo em torno da lei $n^{0} \mathbf{1 3 . 0 0 6}$, que trata da exibição de filmes brasileiros nas escolas. Acredito que essa lei, se de fato implementada no interior das escolas, pode criar um público para o cinema brasileiro e ampliar o repertório dos alunos das escolas públicas, hoje, muito restrito às grandes bilheterias.

Dessa forma, recorro à Bergala (2008, p. 32) que, ao falar da proposta de cinema na escola na França, defende:

Finalmente, a única questão de fundo que realmente vale a pena ser colocada é a seguinte: será que uma instituição como a Educação nacional pode acolher a arte (e o cinema) como um bloco de alteridade? [...] Esse trabalho cabe à escola? Tem ela condições de fazê-lo? Uma resposta se impõe: a escola, tal como funciona, não foi feita para esse trabalho, mas ao mesmo tempo, ela representa hoje, para a 
maioria das crianças, o único lugar onde esse encontro com a arte pode se dar. Portanto, ela deve fazê-lo, ainda que sua mentalidade e seus hábitos sofram um pequeno abalo. Pois, excluindo-se os "herdeiros" no sentido de Bourdieu, tudo o que a sociedade civil propõe à maioria das crianças são mercadorias culturais rapidamente consumidas, rapidamente perecíveis e socialmente "obrigatórias".

Penso que o mesmo argumento serve para a introdução do cinema nacional e de outras narrativas fílmicas que fogem ao padrão de filmes estadunidenses nas escolas públicas do Brasil: possibilitar fruição e experiência estética aos jovens e crianças que, muitas vezes, frequentam apenas este espaço público.

Acredito que muitas das concepções iniciais, levantadas pelos jovens, pesquisados de que o filme brasileiro é ruim ou de baixa qualidade, poderiam ser revistas a partir do olhar que tiveram do filme que assistiram; o fato de muitos deles perceberem diferenças técnicas (como áudio baixo, produção mais barata), não foi empecilho para que grande parte, apesar de um estranhamento inicial, abrisse outro olhar para o audiovisual.

\section{2 \\ O cinema como um espelho desfocado ou Vamos produzir um filme?}

Ao tratar da importância do cinema ser produzido em diferentes países e para diferentes culturas, Carrière (2014, p. 174) afirma:

Assim, num nível mais profundo, devemos questionar se a imagem cinematográfica é necessária às nações. A habilidade de contar a nós mesmos nossas próprias histórias, utilizando os meios mais modernos, de estudar a nós mesmos, em nossos próprios espelhos, será apenas uma forma de realçar a vida ou será essencial para a vida em si? Acredito que seja essencial para a vida.

Partindo de perspectiva semelhante, Martín-Barbero (2013) afirma que o cinema é uma maneira de olharmos para nós mesmos e nos vermos através de um espelho que, às vezes, parece desfocado, pois nos mostra algo um tanto diferente do que pensamos que somos, dando um tom mais elevado ou performático ou amenizando determinados tons.

Durante a pesquisa de campo, alguns jovens pesquisados me procuraram sugerindo que fizéssemos um filme, abordando a temática da juventude. Entendi que esse seria um desafio, mas também um importante passo para a pesquisa, pois parecia uma chance deles contarem, por si mesmos, sua própria história, criando seus próprios espelhos. 
Para desenvolver o trabalho de produção audiovisual com eles, contei com a importante parceria de Elizabeth Caldas, membro do Grupem, roteirista e diretora de cinema, com experiência em oficinas de produção audiovisual. Elizabeth esteve duas tardes com os jovens para tratar de produção de roteiro e questões técnicas, como fotografia, plano, iluminação, trilha sonora, além da importância da definição de um roteiro com todos esses elementos. Depois disso, os jovens, com minha ajuda, montaram um grupo no WhatsApp para finalização do roteiro e definições sobre produção.

Houve dois encontros para gravação do curta-metragem, a partir do roteiro concebido pelo grupo e, como o tempo era curto, Elizabeth ficou responsável pela edição, a partir das marcações deles. No último encontro da pesquisa, pudemos ver o filme e exibi-lo para toda a escola, como uma espécie de estreia.

Antes de analisar o produto final, o curta-metragem produzido pelos sujeitos desta pesquisa, é importante entender o processo de construção e concepção da narrativa, ou seja, compreender como eles chegaram ao roteiro do filme.

\subsection{1 \\ Vamos falar sobre o quê?}

Após apresentar as questões técnicas envolvidas na produção de um filme, Elizabeth pediu que falassem sobre o que pretendiam desenvolver no filme, numa espécie de tempestade de ideias. Nesse primeiro momento, 11 temas sugiram: alunos começaram a ter poderes; crepúsculo/vampiro; pósapocalipse; alunos no bar bêbados; cenas na piscina; mostrar a realidade; aquecimento global; relações entre pais e filhos; problemas da juventude fora da nossa realidade; e casos de ficção.

Nesse primeiro momento, foi possível perceber duas concepções de filme: uma que tratava de temas relacionados à ficção científica, como pós-apocalipse, vampiros e lobisomens e outra que pretendia tratar de temas cotidianos, mais próximos da realidade deles. Ficou evidente, dessa forma, uma divisão da turma entre elementos da ficção/fantasia e elementos que tratam da realidade na produção do filme. É interessante perceber que essa divisão perdurou durante a produção e resistiu no produto final, ou seja, o filme produzido não define a concepção que seria evidenciada. 
Em um segundo momento, os jovens divididos em grupos responderam três questões para embasar a construção do roteiro, visto que precisavam definir mais claramente a proposta do filme. As questões foram: "Do que trata o filme? Quem são os protagonistas? Qual é a mensagem do filme?"

O quadro a seguir apresenta as respostas dos cinco grupos que foram constituídos:

\begin{tabular}{|c|c|c|c|}
\hline & $\begin{array}{l}\text { Questão 1: } \\
\text { Do que trata o filme? }\end{array}$ & $\begin{array}{l}\text { Questão 2: } \\
\text { Quem são os protagonistas? }\end{array}$ & $\begin{array}{c}\text { Questão 3: } \\
\text { Qual é a } \\
\text { mensagem } \\
\text { desse filme? }\end{array}$ \\
\hline 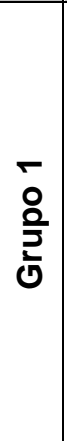 & $\begin{array}{l}\text { Se trata de terror, aventura e } \\
\text { comédia. Seria a história de um } \\
\text { grupo que foi acampar e se } \\
\text { perdeu no meio da mata, e lá } \\
\text { tinha um assassino que andava } \\
\text { com uma foice e máscara de um } \\
\text { diabo vermelha. E nessa } \\
\text { aventura, eles vão ter que } \\
\text { descobrir quem é o assassino. E } \\
\text { esse assassino é uma pessoa } \\
\text { próxima deles. }\end{array}$ & $\begin{array}{l}\text { Primeiro protagonista: lerdo, } \\
\text { engraçado e medroso. } \\
\text { Segundo protagonista: sério, } \\
\text { irônico e não tem medo de nada. }\end{array}$ & $\begin{array}{l}\text { Mesmo que } \\
\text { você seja } \\
\text { retardado e } \\
\text { sonso, não } \\
\text { tenha medo. }\end{array}$ \\
\hline 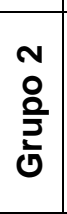 & $\begin{array}{l}\text { Vai se tratar de famílias } \\
\text { divergentes, de famílias que se } \\
\text { dão bem e outras não. }\end{array}$ & $\begin{array}{l}\text { Vai ser a relação entre pais e } \\
\text { filhos, tios e primos. }\end{array}$ & $\begin{array}{l}\text { A mensagem } \\
\text { é de que as } \\
\text { famílias } \\
\text { devem ficar } \\
\text { juntas. }\end{array}$ \\
\hline 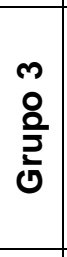 & $\begin{array}{l}\text { Trata-se de uma sala que tinha } \\
\text { muita zoação entre os alunos. } \\
\text { Além de muita zoação tinha } \\
\text { também muito preconceito. }\end{array}$ & $\begin{array}{l}\text { A nerd que vivia apanhando, a } \\
\text { patricinha que fazia bullying, a } \\
\text { maloqueira que vivia fumando, a } \\
\text { funkeira que vivia dançando, a } \\
\text { fofoqueira, o famosinho, a gótica, } \\
\text { o fedorento e a macumbeira. }\end{array}$ & $\begin{array}{l}\text { Não julgar as } \\
\text { pessoas pelas } \\
\text { aparências ou } \\
\text { pelo que elas } \\
\text { são. }\end{array}$ \\
\hline $\begin{array}{l}+ \\
\stackrel{0}{2} \\
\substack{2 \\
0}\end{array}$ & $\begin{array}{l}\text { Nosso filme vai ser de ação, vai } \\
\text { ter luta, morte, violência, roubo } \\
\text { e vingança. }\end{array}$ & $\begin{array}{l}\text { Um homem forte, um homem } \\
\text { vingador e matador. }\end{array}$ & $\begin{array}{l}\text { Nunca faça } \\
\text { violência e } \\
\text { guerra. }\end{array}$ \\
\hline 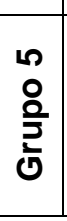 & $\begin{array}{l}\text { O filme se trata de adolescentes } \\
\text { que por algum motivo ganharam } \\
\text { poderes. }\end{array}$ & $\begin{array}{l}\text { Um cara magro que com poderes } \\
\text { fica forte e um cara que era } \\
\text { inteligente e fica mais inteligente } \\
\text { com o poder. }\end{array}$ & $\begin{array}{l}\text { Nunca desista, } \\
\text { mesmo que } \\
\text { seus objetivos } \\
\text { estejam por } \\
\text { um fio. }\end{array}$ \\
\hline
\end{tabular}

Quadro 11 - Respostas dos grupos sobre a proposta de roteiro Fonte: Elaboração própria a partir dos dados da pesquisa.

Vale notar que, ao pensarem na mensagem que o filme iria passar, todos pensaram em algo edificante, uma moral da história seguindo a estrutura de uma fábula. Na concepção deles, a mensagem de um filme deve ser sempre positiva e em forma de algum aprendizado, mesmo aqueles que optaram por filmes de comédia ou suspense, ao final, esperavam "ensinar" algo aos espectadores. 
Das cinco propostas de filme apresentadas, três estão mais ligadas à fantasia e aventura e duas tratam de questões de violência na escola ou conflitos familiares. Apenas uma das propostas apresentam personagens femininas, as demais trazem apenas protagonistas masculinos, sendo que os jovens optam, em todos os cinco grupos, por tipos que são extremamente comuns no cinema: a nerd que sofre bullying, o menino fraco que é muito inteligente, e assim por diante, evidenciando que eles entendem e reconhecem a linguagem ou a gramática dos filmes que costumam ver.

A ideia do que esses alunos pensam sobre a produção de um filme, certamente vem das narrativas que eles estão habituados a ver, o que me remete mais uma vez a Carrière $(2014$, p. 20), que, ao explicar a evolução linguística do cinema afirma:

Os cineastas, que são eles próprios espectadores de filmes feitos por outros, têm uma vaga ideia sobre se serão ou não compreendidos por seus contemporâneos. Este últimos, por sua vez, se adaptam (involuntariamente, com frequência de modo inconsciente) a formas de expressão que por um breve período parecem ousadas, mas logo se tornam lugares comuns. O primeiro homem a fazer a imagem tremer a fim de indicar uma mudança na percepção foi um verdadeiro inovador. O segundo copiou o primeiro, talvez aperfeiçoando o processo. $\mathrm{Na}$ terceira vez, o efeito já era um clichê.

Ao discutirem as cinco propostas apresentadas, os jovens levaram em conta os espaços que seriam usados para locação, dessa forma, logo descartaram a ideia do primeiro grupo, visto que o filme seria todo gravado na escola, no horário das atividades do projeto Contadores de Histórias. A segunda proposta também foi descartada por muitos alunos, que a consideraram muito sem graça. A proposta do grupo 4 foi considerada muito ampla e sem muitos detalhes, por isso também não foi aceita.

Para a construção da ideia central do roteiro, os alunos uniram as ideias apresentadas pelos grupos 3 e 5, porém, nas entrelinhas, ainda é possível ver as propostas 2 e 4, mesmo que elas não tenham aparecido de maneira mais evidente. Depois de muitas discussões e debates eles chegaram ao seguinte argumento: "O filme começa na escola com uma briga geral entre dois dos três protagonistas (João, Ana e Carla). Ana mata João e Carla volta no tempo para consertar o passado."

A partir desse argumento inicial, os jovens coletivamente escreveram o roteiro, usando o WhatsApp e os encontros antes do dia programado para as gravações; eles se organizaram em grupos e cada grupo assumiu funções, tais como: direção, elenco, fotografia, som, técnica, figurino e produção. 


\subsection{2}

\section{Como contar a história?}

Ao acompanhar a produção do roteiro ${ }^{44}$, percebi que a construção de muitas cenas para o curta-metragem foram pensadas tendo como referência os filmes assistidos durante a pesquisa. Vale ressaltar que, até este momento, eles só tinham assistido aos filmes estadunidenses e ao curta-metragem Confusões de adolescentes. O filme As melhores coisas do mundo, que tem a temática do bullying na escola, mesma temática selecionada por eles, ainda não havia sido exibido.

Uma das referências que os alunos usaram está no filme $A$ culpa é das estrelas: depois que saem do hospital, os protagonistas ficam de castigo e conversam via WhatsApp; eles pediram que, neste momento da conversa, fosse usada a mesma técnica do filme, ou seja, aparecessem balõezinhos com suas falas na tela.

Outra referência relaciona-se à narrativa e está ligada à volta no tempo, que ocorre com a personagem Carla. O mesmo ocorreu com a personagem Wolverine em X-Men: dias de um futuro esquecido. O motivo do retorno de ambos é bem parecido: evitar conflitos ou guerra, ou seja, impedir que o conflito do passado estrague o futuro.

Eles escolheram um título em inglês para o filme ( 3 Forces), pois, segundo argumentaram, o filme ficaria mais comercial, uma vez que filmes com títulos em português chamam menos atenção.

Ao pensar o cenário do filme, os jovens tomaram alguns cuidados: escolheram carteiras para a sala de aula que estivessem em melhor estado, optaram por um espaço de uma das salas de aula em que a parede está mais arrumada, pensaram numa cena na entrada da escola, onde tem um jardim e um painel pintado pelos próprios alunos, entre outras escolhas que evidenciaram a vontade de mostrar o que o espaço deles, a escola, tem de melhor. O cenário do hospital foi gravado na cantina e as mesas serviram como macas; para isso, tiveram o cuidado de filmar de baixo para cima, mostrando apenas as partes brancas da cantina, que lembram as paredes de um hospital.

Antes de filmarem, todos se maquiaram e foi possível perceber que as personagens classificadas como más tinham maquiagem mais pesada, assim

\footnotetext{
${ }^{44}$ Como o roteiro foi construído coletivamente, há inúmeros papéis soltos e vários rascunhos que foram usados pelos alunos e depois entregues a mim, porém eles entregaram também um texto em que trabalham o argumento inicial e serve como um resumo do roteiro (Apêndice J).
} 
como acontece com a personagem Malévola, no filme homônimo. Por outro lado, os três alunos nerds, aqueles que sofrem bullying, usam óculos de grau e estão vestidos com uniforme escolar, recorrendo ao clichê de que os inteligentes são representados por símbolos como óculos e roupa mais ajustada ao corpo, além dos cabelos bem assentados.

Outras personagens caracterizadas a partir de clichês foram as enfermeiras, que aplicam injeção nos protagonistas: elas estão de branco, com batons de cores muito fortes e um olhar bastante ameaçador, o que já sugere ao espectador que algo ruim acontecerá. Essa cena foi ensaiada e pensada para dar esse tom, ou seja, eles desejavam que a fisionomia das personagens já indicasse como iriam se desenrolar as cenas seguintes.

$\mathrm{Na}$ cena inicial do filme, os três protagonistas estão sentados nas carteiras bem próximos ao quadro, fazendo uma atividade em grupo. Quando um dos alunos se levanta e pede para copiar o exercício deles, eles não deixam. Logo, outros alunos se levantam e começam a agredi-los com muitos chutes, palavrões, socos e pontapés. Os três são muito agredidos pelos colegas e vão feridos para o hospital.

Nessa cena, em que há uma agressividade muito grande dos alunos que praticam bullying, a violência é forte, tanto física como verbalmente. Destaco que, no momento da preparação do roteiro, um dos sujeitos da pesquisa chegou a comentar que, naquele dia, ele se vingaria, pois sempre havia sofrido bullying dos colegas, mas no filme ele seria o praticante.

\subsection{3}

Quando o espelho causa estranhamento: retratar-se ou apelar para a magia?

Ao analisar a produção criada pelos sujeitos da pesquisa, nos sete minutos e meio de duração da narrativa, percebi três movimentos diferentes: havia ali uma espécie de autorretrato de uma situação incômoda; diante da gravidade do problema e da situação que apresentaram - bullying, sofrimento, violência e morte - eles optaram por uma solução mágica e, ainda, abandonaram a discussão do tema para garantir um happy end.

No primeiro momento, na ambientação da narrativa, é possível perceber claramente a vontade dos jovens de denunciarem a presença do bullying no 
cotidiano escolar. Isso ficou evidente na primeira cena do filme e em todas as vezes que os diretores apresentaram o filme para o público ${ }^{45}$.

Ao apresentarem o curta-metragem, na Mostra Geração do Rio, os jovens disseram:

O nosso filme fala sobre bullying e quando um grupo de amigos sofre bullying, eles vão para o hospital e ganham poderes, porque eles tomam uma injeção e ganham poderes. (Mercúrio).

É importante fazer um filme falando sobre isso porque sempre ocorre casos de bullying e racismo e a gente só pegou essa ideia e transformou num curta. Porque na nossa escola sempre tem este tipo de gente falando que a pessoa é feia, é gorda [...] a gente encontrou um jeito diferente de resolver esta questão. (Coringa).

As falas dos alunos e as cenas iniciais do filme, cheias de agressividade $\mathrm{e}$ um tom sério, anunciavam a vontade de tratar do assunto de maneira a explorar o problema e a pensar em soluções práticas para resolvê-lo.

Porém, nas cenas seguintes, há a opção em resolver o problema simplesmente evitando-o e, para isso, propõem a volta de uma das personagens no tempo, que enfrenta os seus agressores com palavras fortes, um discurso com tom sério, mas, na prática, seria sem efeito. Ela, na verdade, resolve o problema da morte de sua amiga a partir de uma solução mágica (a volta no tempo), mas isso não evitará que, em outras circunstâncias, o fato volte a ocorrer na escola.

O "jeito diferente" que os alunos encontraram para resolver a situação não resolve o problema levantado por eles. Eles mostram que esse conflito ocorre na escola deles e em outras, mas não sabem como resolvê-lo. Talvez por isso a fantasia tenha aparecido ou, ainda, mais adiante, eles tenham abandonado o tema para garantir um desfecho feliz da narrativa.

As soluções encontradas por eles são soluções simplificadoras e extremas, pois evidenciam que elas nunca estão próximas de quem vivencia o problema.

Pensando nas questões de estrutura da narrativa, a morte de uma das protagonistas é uma ruptura ao modo como o tema vinha sendo desenvolvido, que incluía até mesmo a maneira como eles percebem a presença dos pais em seu cotidiano. Em uma das cenas anteriores, a mãe do protagonista o deixa de castigo por causa da briga na escola, logo em seguida, essa mesma

\footnotetext{
${ }^{45} \mathrm{O}$ filme foi apresentado na escola para todos os alunos do $6^{\circ}$ ao $9^{\circ}$ ano como produto final do projeto Contadores de Histórias. Esse curta-metragem foi um dos selecionados para a Mostra Geração do Festival do Rio e parte dos jovens puderam apresentá-lo e assisti-lo numa sala de cinema, assim como outros filmes de jovens que foram selecionados, além disso, apresentaram o filme para outros jovens presentes na mostra.
} 
personagem age com tamanha agressividade contra sua amiga e acaba matando-a. A cena perde verossimilhança e quebra a previsibilidade, além da incoerência dos atos das personagens que, em um momento, parecem tão afetuosas com os que as cercam e, no momento seguinte, agem com tamanha violência. Essa cena da morte é muito diferente do que ocorreu, por exemplo, na cena do hospital, quando o olhar das enfermeiras já adiantava que algo ruim estava para acontecer; nesta, o imprevisível fica inverossímil demais.

No caso da cena da briga, não há nenhuma preparação para a cena seguinte. A personagem Carla, logo em seguida, ao invés de cuidar de sua amiga caída, vai para outro canto chorar e volta no tempo. Não é possível saber o que ocorre com o agressor, que é amigo da vítima. Nesse sentido, há um abandono da discussão do bullying, que seria o tema central da narrativa, e no lugar dele, a solução mágica aparece.

Penso que há duas questões importantes que os jovens pesquisados puderam vivenciar ao produzir o curta-metragem. A primeira foi conhecer algumas técnicas de produção audiovisual, o que os deixou mais atentos para outros filmes que viram e, certamente, mudou o olhar deles para o cinema.

Isso pode ser constatado, por exemplo, quando, na visualização do filme As melhores coisas do mundo, muitos deles comentaram questões técnicas e, na atividade posterior à visualização, mencionaram problemas com som e a diferença entre as técnicas de edição dos filmes estadunidenses e do filme visualizado.

A segunda foi apresentar um tema que, certamente, atinge grande parte da juventude, o bullying, porém, fica evidente que, apesar de ser um tema que os atinge, eles não parecem saber como lidar com ele e nem compreendê-lo em suas múltiplas dimensões e implicações. Parecem também pouco dispostos a enfrentar o tema realisticamente, talvez por não terem "armas" para essa "batalha", provavelmente porque ainda precisem da interferência dos adultos, ou até porque, como nos filmes que eles veem, quisessem apenas que o espectador pudesse apreciar a obra. No padrão narrativo com o qual estão acostumados, isso exige fantasia e final feliz. 


\title{
8 \\ Considerações finais
}

\author{
Porque se chamava moço \\ Também se chamava estrada [...] \\ Porque se chamava homem \\ Também se chamavam sonhos [...] \\ (Clube da Esquina II, Lô Borges e Milton Nascimento, 1972).
}

Durante o desenvolvimento da pesquisa que originou esta tese, ficou bastante evidenciado o enorme poder de mercado da indústria cinematográfica estadunidense. Os filmes hollywoodianos são tidos como referências tanto estético-narrativas quanto em relação à política de distribuição e exibição.

Os dados sobre a indústria cinematográfica que foram apresentados mostram que os filmes de grandes bilheterias no Brasil, e também em vários países do mundo, são os filmes produzidos em Hollywood. Além disso, estes filmes saem das salas de cinema e vão, em curto espaço de tempo, para os canais de TV fechados, suportes streaming (como Netflix e Youtube) e, em seguida, para a TV aberta. O que facilita sua ampla divulgação em curto espaço de tempo.

Vale ressaltar que, nos últimos anos, o tempo entre a estreia de um filme nas salas de cinema e sua chegada aos outros suportes tem sido cada vez menor, o que facilita, conforme apresentado nesta tese, a divulgação destas narrativas, mesmo para o público que não tem o hábito de ir ao cinema.

$\mathrm{Na}$ lista dos 20 filmes mais vistos nas salas de cinema brasileiras, em 2014, há apenas um filme brasileiro, todos os outros são estadunidenses e, destes, metade são filmes para o público jovem ou infantil. Dessa forma, há além de um investimento massivo na produção, distribuição e exibição dos filmes, conforme constatado, também uma estratégia de formação de público , o que pode ser confirmado pelo número de filmes para o público jovem, além de uma padronização estético-narrativa de filmes para este público, o que, na prática, facilita a adesão por um tipo de filme, que passa pela estrutura narrativa, mas também pela imagem e som produzidos, que incluem determinadas características físicas de atores, efeitos especiais, qualidade de áudio e outras questões técnicas a que o espectador se acostuma.

Neste sentido, o audiovisual estadunidense é de alto investimento, porém tem retorno assegurado tanto no que diz respeito à distribuição e exibição, quanto à venda de produtos vinculados à marca dos filmes, através da chamada 
convergência das mídias (Jenkins, 2009). A juventude não consegue ficar imune a todas estas estratégias de mercado e, na maioria das vezes, se identifica com as narrativas apresentadas.

Ao retomar o objetivo geral deste trabalho que é analisar como os jovens se relacionam com a padronização que o cinema faz da juventude em filmes de grandes bilheterias, posso concluir que, apesar das diferenças de acesso que estão muito ligadas às questões socioeconômicas, ou seja, enquanto os jovens das classes mais favorecidas assistem aos filmes na semana de sua estreia nos cinemas, os jovens das classes populares aguardam sua exibição na TV, ou o assistem por meio de um DVD pirata; as juventudes não costumam questionar ou ter um olhar mais atento e crítico para os filmes que assistem. Essa falta de questionamento se dá em função de grande parte dos jovens, independentemente de suas classes sociais, não conhecerem outras estruturas fílmicas, por estarem acostumados às narrativas de grandes bilheterias, sendo assim, qualquer narrativa que saia desse modelo/padrão causa estranhamento.

No caso desta pesquisa, em se tratando da maneira como os jovens perceberam/analisaram as configurações de juventudes nos filmes, é possível supor que, em vários momentos, eles conseguiram identificar muitas semelhanças entre personagens e mesmo algumas simplificações na elaboração do perfil psicológico de alguns deles, mas poucas vezes isso causou incômodo ou foi traduzido numa vontade de verem suas características, sua cultura ou seu contexto social representados em uma narrativa cinematográfica.

Nas atividades em que foram convidados a sugerir novos roteiros para os filmes vistos, eles não propuseram mudanças substanciais no perfil das personagens e nem na estrutura das narrativas. Isso não é falta de criatividade, como alguns poderiam inferir, nem mesmo falta de estrutura semântica e vocabular para propor novos roteiros, mas a percepção deles de que existe um modelo adequado, uma fórmula, um padrão de fazer filmes, e este modelo são os filmes a que têm acesso, ou seja, os filmes da indústria hollywoodiana. Neste sentido, eles não se sentem autorizados a mudar nada, ou quase nada, porque se identificam com essas narrativas e porque supõem que há um "jeito certo" de fazer filmes.

A conformidade com as configurações de jovens que eles veem nos filmes é também confirmada quando desenham modelos de figurinos para uma personagem (Katniss Everdeen, Jogos vorazes: a esperança - parte 1), e estes são, quase unicamente, baseados em outras personagens do cinema, em super-heróis que conhecem e eventualmente inspirados em cantoras pop, 
modelos vistos cotidianamente nos meios de comunicação. Esses modelos e tipos também são reproduzidos no curta-metragem que eles produziram, conforme apresentado no capítulo 7.

A partir destas constatações, que apontam para uma espécie de monopólio das narrativas audiovisuais vindas dos Estados Unidos, que têm um padrão de produção, de distribuição e de exibição e que, em função disso, transformam o público, em especial o público jovem, num mercado consumidor primordial e essencial para a sua manutenção, buscando manter um controle rigoroso sobre este público, penso que há apenas um caminho, na perspectiva de deixar a relação entre juventudes e audiovisual mais equânime: apresentar aos jovens outras narrativas audiovisuais, mas ao mesmo tempo não impedi-los de visualizarem as narrativas com as quais estão familiarizados.

É possível, a partir do escopo fílmico que estes jovens têm que são, em sua maioria, os filmes de grandes bilheterias com narrativas padronizadas, educar para as mídias, apresentando outros olhares e outras possibilidades de intervenção. .

Vale lembrar, neste sentido, conforme Martín-Barbero (2013), que nem toda recusa é resistência, resistir pode ser assimilar para contrapor e subverter. Acredito que diante de uma indústria tão forte quanto a indústria do audiovisual estadunidense, como demonstrado no decorrer deste trabalho, qualquer sujeito ou entidade que tentasse barrar a entrada destas narrativas nas comunidades juvenis seria fortemente criticado e poderia perder a oportunidade de diálogo.

Além disso, penso que a disputa a ser travada é por duas diferentes concepções de espectador (cf. Fonseca, 2016), um primeiro que fica dependente do entretenimento, e este ato tende à alienação, e o segundo que vê o audiovisual como uma prática reflexiva. Este segundo pensamento está muito ligado aos estudos do campo da comunicação latino-americano, do qual MartínBarbero é um dos representantes, enquanto o primeiro se aproxima dos estudos da escola de Frankfurt, cujo representante de maior destaque é Theodor Adorno, já citado nesta tese.

Acredito que seja possível ver os filmes propostos nesta pesquisa não apenas na perspectiva do entretenimento, da submissão à indústria cultural, conforme sugere Adorno (2015), mas a partir de uma conversão do espectador em sujeito crítico, isso é possível, a meu ver, a partir da visualização ou exibição mediada. Entendo que a mediação é capaz de penetrar no sistema "impermeável" em que tenta se configurar a indústria cultural. 
Diante desta perspectiva, a lei oㅜ 12.485/11 (lei de Cotas de Tela) e a lei 13.006/14 (que trata da exibição de 2 horas mensais de filmes nacionais na escola) podem contribuir enormemente para que este caminho seja trilhado. $A$ primeira, porque garante que filmes brasileiros sejam obrigatoriamente exibidos por canais pagos (conforme apresentado no capítulo 6 desta tese), o que, na prática, pode garantir ao espectador a oportunidade de conhecer narrativas audiovisuais brasileiras e interessar-se por elas, percebendo diferenças de contextos entre estas e as narrativas produzidas em outros países, sobretudo as estadunidenses. Para as produtoras de filmes, esta é uma maneira não só de publicizar suas produções, mas também de ganhar financeiramente com elas e, consequentemente, poderem investir na qualidade de seus produtos e competirem por espaços de uma maneira menos desigual com as empresas hollywoodianas.

No caso da lei 13.006/14, que está mais diretamente ligada às relações entre o contexto escolar, o acesso aos bens culturais e a formação estéticoaudiovisual, creio que se ela for bem acolhida e implementada nas unidades educacionais, de maneira a envolver todos os atores da escola, pode ser um caminho para a mudança de concepção dos alunos acerca das narrativas audiovisuais, abrindo oportunidades desses alunos conhecerem não somente as produções de grandes bilheterias que são, na atualidade, as que chegam até eles com mais facilidade, mas seria o momento de terem acesso a outras produções, que partem de outras perspectivas narrativas. Porém, para que, de fato, a implementação desta lei não seja apenas mais um dever legal da escola, é preciso pensar ações que contribuam para a formação tanto dos jovens quanto da comunidade escolar.

Torna-se imprescindível, ainda, que a lei, além de ser de fato implementada na escola, seja de conhecimento dos atores escolares, assim como da comunidade em geral, visto que, apesar de ter sido aprovada em 2014, muitos professores e formadores de profissionais da educação ainda não tiveram acesso ao seu conteúdo ou, simplesmente, desconhecem a existência dela. Além disso, é preciso discutir formas de levá-la ao cotidiano da escola e torná-la, de fato, uma realidade no contexto educacional brasileiro.

Da mesma forma que muitos alunos só têm acesso aos filmes que passam na TV, conforme foi detectado a partir de questionário aplicado aos jovens desta pesquisa, muitos professores também não vão ao cinema com frequência e não tiveram, em sua trajetória, uma formação para o audiovisual, portanto, é preciso, que nos espaços de formação continuada ou formação em contexto dos 
professores sejam abertas possibilidades para a literacia fílmica deles. Isso pode ser feito a partir de contato das escolas e/ou redes de ensino com as universidades próximas ou mesmo com profissionais da Educomunicação, ou ainda, a partir dos próprios profissionais da escola que tiveram ou têm uma relação mais próxima com o cinema. Neste último caso, as trocas e compartilhamentos entre professores que trabalham juntos tendem a ser, muitas vezes, mais eficazes, pois não há aqui um distanciamento entre quem aprende e quem ensina, todos se colocam num mesmo patamar e trocam experiências.

Ainda em relação à lei $13.006 / 14$, penso que exibir filmes de nossa nacionalidade sem uma contextualização ou atividade que contribua para a formação estética dos alunos seja improdutivo, visto que, muitos deles, têm uma concepção de que os filmes brasileiros são ruins. Esse preconceito com filmes brasileiros ficou evidenciado, nesta pesquisa, com a visualização do filme As melhores coisas do mundo, em que, inicialmente, durante a exibição do filme, houve muitas críticas negativas, ou mesmo, quando para produzir o filme deles, ele usaram estratégias vistas em narrativas estadunidense. Porém, no momento seguinte à exibição d'As melhores coisas do mundo, em que houve o debate e a atividade prática em torno do filme, algumas concepções dos jovens mudaram, pois eles puderam refletir acerca da história narrada e, até mesmo, constataram similaridades entre a narrativa e a realidade deles, assumindo assim, um papel mais crítico.

Acredito, neste sentido, que os filmes exibidos na escola devam ter objetivos mais amplos do que cumprir a lei ou servir de entretenimento. Defendo, assim, que o cinema esteja presente na escola na perspectiva da visualização, ou seja, da exibição mediada que leve à reflexão sobre a estrutura estéticonarrativa. Penso que os filmes brasileiros devam ser apresentados em contraponto aos filmes a que os jovens têm mais acesso, ou seja, como uma maneira de subverter a ordem proposta pela indústria cultural e formar um público para o audiovisual com um olhar mais atento e responsável, na perspectiva da educação para as mídias.

É possível pensar, por exemplo, num tempo-espaço mensal entre as disciplinas curriculares ou, no caso das escolas de tempo integral, nos projetos extracurriculares desenvolvidos, em que dois filmes sejam visualizados, um aquele que os alunos já têm acesso e outro, um filme nacional, conforme previsto pela lei. Assim, a lei estaria sendo cumprida de maneira a fazer sentido para o contexto escolar e para o aluno. 
É essencial que essas atividades tenham sempre a mediação de um professor ou um convidado pelo professor ou pelos próprios alunos que possam discutir sobre as diferenças entre os filmes vistos. As discussões posteriores aos filmes podem ser dialogadas ou mesmo podem acontecer a partir de atividades práticas propostas pelo mediador. As visualizações de filmes podem ser complementadas com desenhos, performances, escritas, reescritas, gravações e reproduções de cenas ou outra atividade que embase uma reflexão sobre as narrativas visualizadas.

As questões abordadas podem e devem variar: se no primeiro mês optarem por discutir o figurino das personagens, no mês seguinte, a opção pode ser pela estrutura narrativa, em outro a caracterização das personagens, mais à frente, a biografia dos atores que participam dos filmes e, assim sucessivamente. Creio que desta forma, a escola estará contribuindo de maneira eficaz com a formação crítica e estético-audiovisual de seus alunos, dando oportunidades de enriquecimento cultural para muitos que, como os sujeitos desta pesquisa, têm na escola um de seus principais suportes estético-culturais, quando não o único.

Acredito, ainda, que uma das funções sociais da escola é educar seus alunos para os meios de comunicação de massa, não só para que eles entendam como estes funcionam, mas para que possam fazer parte deles, produzindo, mesmo que em menor escala, produtos audiovisuais que reflitam suas aspirações, desejos, sonhos e reflexões.

Entendo que, além do importante papel social da escola na formação destes jovens para lidar com narrativas audiovisuais, é importante, também, que o poder público formule e implemente políticas culturais mais abrangentes, que cheguem às cidades e bairros periféricos, pois, conforme relatado neste trabalho, muitos dos jovens pesquisados não têm acesso a bens culturais a não ser por meio da escola. A falta de acesso à diversidade da produção cultual enviesa o olhar deles, padroniza gostos e aprofunda as desigualdades econômicas e educacionais.

É preciso que as políticas de cultura promovam o acesso de todos aos bens culturais, posto que a democratização destes é caminho para a formação cidadã e para os demais espaços sociais e políticos. Por isso, a importância de que os jovens pesquisados, assim como os demais, conheçam diversos modelos de narrativas audiovisuais; isso pode contribuir para reforçar o gosto deles pelos filmes com os quais já têm contato e/ou para passarem a gostar de outros tipos de narrativas, aquelas a que eles não têm acesso. Como assinala Fischer (1959, p. 19): "Quanto mais chegamos a conhecer trabalhos de arte há muito 
esquecidos ou perdidos, tanto mais claramente enxergamos, apesar das variedades deles, seus elementos contínuos e comuns".

O que é, na verdade, excludente e amplia as desigualdades sociais, educacionais e culturais é o acesso limitado aos bens culturais disponíveis. $O$ gosto por um ou outro padrão estético só poderia ser, de fato, levado em conta, se os espectadores tivessem acesso a todos eles, fora isso, o espelho sempre estará turvo e impedirá a visão completa do espectador, pois ele estará submisso a uma única possibilidade de narrativa ou de arte.

Ao iniciar esta tese, propus como reflexão, a partir da questão de pesquisa, a metáfora do espelho desenvolvida por Pais $(2009,2014)$, que afirma que "o espelho turva ou deforma a realidade refletida" (Pais, 2014, p. 72), pois só reflete e se deixa refletir. Nos mesmos textos, porém, o autor reconhece que para tratar das representações sociais o ideal seria usar a metáfora da oficina, do caminhante ou da construção. Segundo ele, "se a representação social é apresentada como uma construção, o mundo existe na medida em que se fala ou se escreve sobre ele." (p. 72).

Entendo que, em muitos momentos, os jovens participantes desta pesquisa se viram como espelhos ou espelhados, ou seja, viram as imagens de juventude presentes nos filmes e se identificaram com elas, mesmo percebendo o quanto elas poderiam estar distantes de sua realidade. Em outros momentos, mesmo que timidamente, questionaram a natureza e a veracidade daquelas formas de configuração das juventudes e das narrativas. Nestes momentos, pareciam perceber que as configurações são construídas coletivamente, nas linguagens, e que, portanto, seria possível construir outras imagens, ou seja, de que o espelho pode apresentar outros reflexos.

Vale ressaltar, como exposto neste capítulo final, que os jovens pesquisados têm acesso a um único tipo de narrativa fílmica, o que dificulta, em muitos momentos, uma reflexão mais responsável das narrativas visualizadas, colocando-os numa perspectiva submissa, tentando apenas ver o espelho e não a estrada.

Durante o desenvolvimento da pesquisa, vi muitos espelhos virarem caminhantes e vi também muitos espelhos desfocarem-se, ora por medo de assumirem um caminho diferente do proposto pelos filmes que estão acostumados a ver, ora por não conhecerem outro modo de caminhar.

O caminho e o espelho ficam lado a lado e relutam o tempo todo quando eles querem ser ou se parecer com os jovens representados nos filmes a que assistem, mesmo diante de um distanciamento enorme. Isso fica evidente, por 
exemplo, quando escolhem seus codinomes, muitos deles inspirados nos filmes de grandes bilheterias a que têm acesso. Ou também quando expressam o desejo de ter algum objeto ou bem de consumo igual ao possuído por alguma personagem - os quartos dos protagonistas de $A$ culpa é das estrelas, por exemplo - ou mesmo quando se vestem de forma parecida com aquelas que viram nos filmes que integraram as atividades realizadas na pesquisa ou de outros filmes de mesmo padrão que fazem parte de seu repertório.

Percebi, a partir das histórias compartilhadas com estes jovens, o quanto o cotidiano pode ser duro, mas pode também mostrar-se cheio de fantasias, as quais levam esses jovens a querer agir como os jovens do filme As crônicas de Nárnia, que preferem refugiar-se num armário e vivenciarem um mundo paralelo cheio de outros conflitos existenciais a ter de viver uma guerra de verdade. Nesse sentido, muitas vezes, eles ficam entre a "estrada" e os "sonhos" (que se refletem nos espelhos audiovisuais).

Cabe ressaltar que, neste trabalho, houve a opção por uma pesquisa que retratasse e analisasse um grupo de jovens bastante específico, sujeitos que moram num bairro periférico da cidade de Juiz de Fora e que têm a escola como lugar central em suas vidas, até em função do tempo em que passam nela, cerca de 40 horas semanais. Porém, mesmo sabendo que as juventudes são diversas, é importante perceber que, em determinados momentos, elas são ligadas às culturas juvenis e neste momento os jovens se aproximam. É possível, neste momento de aproximação, ver nestes jovens da periferia traços, gostos e maneiras de ver e interpretar o mundo muito parecidos com outros jovens que têm o acesso mais facilitado aos bens culturais. 


\section{9 \\ Referências bibliográficas}

ADORNO, Theodor W. Indústria cultural e sociedade. Trad. Julia Elisabeth Levy e outros. Seleção de Textos Jorge Mattos Brito de Almeida. 9. ed. São Paulo: Paz e Terra, 2015.

ADORO Cinema. Crepúsculo. Disponível em: Disponível em: <http://www.adorocinema.com/filmes/filme-131377/>. Acesso em: 31 maio 2017.

AFONSO, Maria Lúcia M. Oficinas em dinâmica de grupo: um método de intervenção psicossocial. Belo Horizonte: Edições do Campo Social, 2000.

AGÊNCIA NACIONAL DO CINEMA (Ancine). Tire suas dúvidas sobre a lei da TV Paga. Disponível em: <https://www.ancine.gov.br/pt-br/faq-lei-da-tv-paga>. Acesso em: 19 jun. 2017.

Informe de acompanhamento do mercado. Distribuição em Salas de Exibição - Informe Anual 2014. Publicado no Observatório Brasileiro do Cinema e do Audiovisual (OCA) em 27 maio 2015. Disponível em: <http://oca.ancine.gov.br/sites/default/files/cinema/pdf/Anuario_2014.pdf>.

Acesso em: 06 set. 2015.

Relatório anual: distribuição em salas 2008. Superintendência de Análise de Mercado. Republicação no Observatório Brasileiro do Cinema e do Audiovisual (OCA) em 2015. Disponível em: <http://oca.ancine.gov.br/sites/default/files/cinema/pdf/Relatorio_Distribuicao_20 08.pdf>. Acesso em: 31 maio 2017.

Listagem de filmes brasileiros lançados 1995 a 2012. Publicado no Observatório Brasileiro do Cinema e do Audiovisual (OCA). 2013. Disponível em: $<$ http://oca.ancine.gov.br/sites/default/files/cinema/pdf/2102_0.pdf>. Acesso em: 28 jun. 2017.

ALTHUSSER, Louis. Ideologia e aparelhos ideológicos de estado: notas para uma investigação. In: ZIZEK, Slavoj. Um mapa da ideologia. Rio de Janeiro: Contraponto, 1996. p. 105-142.

ANDRADE, Marcelo; LUCINDA, Maria da Consolação. Oficinas pedagógicas em direitos humanos: uma aposta de formação política com grupos populares. In: CANDAU, Vera Maria; SACAVINO, Suzana (Org.). Educar em tempos difíceis: construindo caminhos. Rio de Janeiro: 7Letras, 2011. p. 253-272.

ASSOCIAÇÃO BRASILEIRA DE TELEVISÃO POR ASSINATURA (ABTA). MídiaFatos TV por assinatura 2014. Publicação Anual da ABTA com dados da TV por assinatura no Brasil. São Paulo, 2014. Disponível em: <http://www.midiafatos.com.br/site2014/index.html\#2/z>. Acesso em: 2 set. 2015. 
ASSOCIAÇÃO BRASILEIRA DE TELEVISÃO POR ASSINATURA (ABTA). Dados do setor. Disponível em: <http://www.abta.org.br/default.asp>. Acesso em: 3 set. 2015.

BAUER. Martin W. Análise de conteúdo clássica: uma revisão. In: BAUERRR, Martin W.; GASKEL, George (Org.). Pesquisa qualitativa com texto: imagem e som - um manual prático. Trad. Pedrinho A Guareschi. 11. ed. Petrópolis: Vozes, 2013. p. 189-217.

BERGALA, Alain. A hipótese do cinema: pequeno tratado de transmissão do cinema dentro e fora da escola. Trad. Mônica Costa Netto, Silvia Pimenta. Rio de Janeiro: Booklink; CINEAD-LISE-FE/UFRJ, 2008.

BRASIL. Ministério da Cultura. Cultura em números: anuário de estatísticas culturais. 2. ed. Brasília: MinC, 2010. Disponível em: <http://portal.iphan.gov.br/uploads/ckfinder/arquivos/Cultura_em_Numeros_2010 \%281\%29.pdf>. Acesso em: 14 out. 2015.

Ministério da Educação. Manual do PDDE-Interativo 2014. Brasília, DF: Coordenação Geral de Gestão Escolar/DAGE/SEB, 2014a. Disponível em: $<$ http://pdeinterativo.mec.gov.br/pddeinterativo/manuais/ManualPDDEInterativo2014 .pdf>. Acesso em: 27 ago. 2015.

Secretaria de Comunicação Social. Pesquisa brasileira de mídia 2015: hábitos de consumo de mídia pela população brasileira. Brasília: Secom, 2014b. Disponível em: <http://www.secom.gov.br/>. Acesso em: 5 out. 2015.

Programa Mais Educação. Disponível em: <http://portal.mec.gov.br/programa-mais-educacao/apresentacao>. Acesso em: 15 out. 2015.

BORGES, Márcio; BORGES, Lô; NASCIMENTO, Milton. Clube da Esquina $n^{\circ} 2$. In: CLUBE da Esquina. Rio de Janeiro: EMI-Odeon, 1972.

BOURDIEU, Pierre. Gostos de classe e estilos de vida. In: ORTIZ, Renato (Org.). A sociologia de Pierre Bourdieu. São Paulo: Olho d'Água, 2013. p. 73-111.

CANEVACCI, Massimo. Culturas extremas: mutações juvenis nos corpos da metrópoles. Trad. Alba Olmi. Rio de Janeiro: DP\&A, 2005.

CARNEIRO, Raquel. Assim como o livro, "A culpa é das estrelas" é filme para ser sentido. Revista Veja, 5 jun. 2014. Disponível em: $<$ http://veja.abril.com.br/entretenimento/assim-como-o-livro-a-culpa-e-dasestrelas-e-filme-para-ser-sentido/>. Acesso em: 24 jun. 2017.

CARRANO, Paulo. Uma escola pública de ensino médio nas redes sociais de internet: notas de pesquisa. In: JORNADAS INTERNACIONALES "SOCIEDADES CONTEMPORÁNEAS, SUBJETIVIDAD Y EDUCACIÓN. 2., 2014, Buenos Aires. Anais... Buenos Aires, 2014. 
CARRANO, Paulo; FÁVERO, Osmar (Org.). Narrativas juvenis e espaços públicos: olhares de pesquisa em educação, mídia e ciências sociais. Niterói: Editora da UFF, 2014.

; BRENNER, Ana Karina. A escuta de jovens em filmes de pesquisa. Educação \& Realidade, Porto Alegre, v. 42, n. 2, p. 439-454, abr./jun. 2017. Disponível em: <http://dx.doi.org/10.1590/2175-623664317>. Acesso em: 12 set. 2017.

CARRIÈRE, Jean Claude. A linguagem secreta do cinema. Trad. Fernando Albagli e Benjamin Albagli. Rio de Janeiro: Nova Fronteira, 2014.

CESTARIA, Carolina. Público de cinema cresceu 43\%. Revista Meio \& Mensagem. Disponível em: <http://www.meioemensagem.com.br/home/midia/noticias/2014/02/27/Publicode-cinema-cresceu-43-.html>. Acesso em: 5 out. 2015.

CHAMPANGNATTE, Dostoiewski Mariatt de Oliveira. Concepções acerca do professor e da escola no cinema brasileiro: análises críticas de discursos fílmicos. Educação: Teoria e Prática, Rio Claro-SP, v. 26, n. 53, p. 413-427, set./dez. 2016.

CONVERSA com Ana Rosas Mantecón e Néstor Canclini na Fundação Casa de Rui Barbosa. Rio de Janeiro, 17 abr. 2015. Disponível em:<https://www.youtube.com/watch?v=QFkfM3ONbfE>. Acesso em: 1ํㅗ set. 2015.

CORROCHANO, Maria Carla. Jovens no ensino médio: qual é o lugar do trabalho? In: DAYRELL, Juarez; CARRANO, Paulo; MAIA, Carla Linhares (Org.). Juventude e ensino médio: sujeitos e currículos em diálogo. Belo Horizonte: Editora UFMG, 2014. p. 205-228.

CRUZ, Felipe Branco; RODRIGUES, Leonardo. Hollywood bate recorde histórico e fatura US\$ 11 bilhões em 2015. UOL, São Paulo, 20 dez. 2015. Disponível em: $<$ https://cinema.uol.com.br/noticias/redacao/2015/12/30/hollywood-bate-recordehistorico-e-fatura-us-11-bilhoes-em-2015.htm>. Acesso em: 15 jun. 2017.

DAYRELL, Juarez. O jovem como sujeito social. Revista Brasileira de Educação, n. 24, p. 40-52, 2003.

DAYRELL, Juarez. A escola "faz" as juventudes? Reflexões em torno da socialização juvenil. Educação e Sociedade, Campinas, v. 28, n. 100 (especial), p. 1105-1128, out. 2007.

; CARRANO, Paulo. Juventude e ensino médio: quem é este jovem que chega à escola. In: ; MAIA, Carla Linhares (Org.). Juventude e ensino médio: sujeitos e currículos em diálogo. Belo Horizonte: Editora UFMG, 2014. p. 101-134. 
DIONNE, Hugues. A pesquisa-ação para o desenvolvimento local. Trad. Michel Thiollent. Brasília: Liber Livro Editora, 2007.

DUARTE, Rosália. Pesquisa qualitativa: reflexões sobre o trabalho de campo. Cadernos de Pesquisa, n. 115, p. 139-154, 2002.

(Org.). A televisão pelo olhar das crianças. São Paulo: Cortez, 2008.

DUSSEL, Inés. VI Foro Latinoamericano de Educación: educación y nuevas tecnologias - los desafíos pedagógicos ante el mundo digital. Buenos Aires: Santillana, 2010.

ECO, Umberto. Apocalípticos e integrados. São Paulo: Perspectiva, 1970.

ESCOLA MUNICIPAL JOSÉ CALILI AHOUAGI. Projeto político pedagógico: novo tempo. Juiz de Fora: [s.: n.], 2013.

ENNE, Ana Lúcia Silva. Conexões entre juventude, consumo e mídia: Múltiplas formas de atuação e apropriação. In: CARRANO, Paulo; FÁVERO, Osmar. Narrativas juvenis e espaços públicos: olhares de pesquisa em educação, mídia e ciências sociais. Niterói: Editora da UFF, 2014. p. 131-155.

FEIJÓ, Martin Cezar. O que é herói. São Paulo: Brasiliense, 1984. (Primeiros Passos).

FISCHER, Ernst. A necessidade da arte. Trad. Leandro Konder. São Paulo: Círculo do Livro, 1959.

FONSECA, Mirna Juliana Santos. Cinema na escola pra quê. Revista Educação e Cultura Contemporânea, v. 13, n. 31, p. 32-55, 2016. Disponível em: $<$ http://periodicos.estacio.br/index.php/reeduc/issue/view/96/showToc>. Acesso em: 12 jul. 2017.

FRANCO, Maria Laura P.B. Análise de Conteúdo. Brasília, 4. Ed.: Liber Livro, 2012.

FREITAS, Cristiane. Imagens cinematográficas: o prazer do encontro. Logos: Revista da Faculdade de Comunicação da Uerj, ano 9, n. 17, p. 61-67, 2002.

FRESQUET, Adriana; MIGLIORIN, Cezar. Da obrigatoriedade do cinema na escola, notas para uma reflexão sobre a lei 13.006/14. In: (Org.). Cinema e educação: a lei 13.006 - reflexões, perspectivas e propostas. Belo Horizonte: Universo Produções, 2015. Disponível em: $<$ http://www.redekino.com.br/wpcontent/uploads/2015/07/Livreto_Educacao10CineOP_WEB.pdf>. Acesso em: 20 jun. 2017.

GARBIN, Elisabete Maria. Cultur@s juvenis, identid@des e internet: questões atuais. Revista Brasileira de Educação, n. 23, p. 119-135, 2003. 
GARCEZ, Andrea; DUARTE, Rosália; EISENBERG, Zena. Produção e análise de videogravações em pesquisas qualitativas. Educação e Pesquisa, São Paulo, v. 37, n. 2, p. 249-262, maio/ago. 2011.

GARCÍA CANCLINI, Néstor. Culturas híbridas: estratégias para entrar e sair da Modernidade. Trad. Ana Regina Lessa. 4. ed. São Paulo: Editora da Universidade de São Paulo, 2008a.

Leitores, espectadores e Internautas. Trad. Ana Goldberger. São Paulo: lluminuras, 2008b.

Diferentes, desiguais e desconectados: mapas da interculturalidade. Trad. Luiz Sérgio Henriques. 3. ed. 1. reimp. Rio de Janeiro: Editora UFRJ, 2015.

GIROUX, Henry. O filme kids e a política de demonização da juventude. Educação e Realidade, Porto Alegre, v. 21, n. 1, p. 123-36, jan./jun. 1996.

JACKS, Nilda. Mídia nativa: indústria cultural e cultura regional. Porto Alegre: Editora da Universidade/UFRGS, 1998.

JENKINS, Henry. Cultura da convergência. Trad. Susana L. Alexandria. 2. ed. São Paulo: Aleph, 2009.

JUIZ DE FORA. Secretaria de Assistência Social. Subsecretaria de Vigilância e Monitoramento de Assistência Social. Mapa social: análise da situação do desenvolvimento familiar em Juiz de Fora. Juiz de Fora (MG): Funalfa, 2012.

KELLNER, Douglas. A cultura da mídia: estudos culturais - identidade e política entre o moderno e o pós-modernos. Tad. Ivone Castilho Benedetti. Bauru. São Paulo: EDUSC, 2001.

; SHARE, Jeff. Educação para a leitura crítica da mídia, democracia radical e a reconstrução da educação. Educação e Sociedade, Campinas, v. 29, n. 104 (especial), p. 687-715, out. 2008.

LIMA, Yuska; ABADE, Flávia. A oficina de Intervenção Psicossocial como estratégia de formação e articulação no trabalho com educadoras no contexto da pesquisa-ação. In: ABRASPSO. 15., 2009, Maceió. Anais eletrônicos... Maceió: Abrapso, 2009. Disponível em: <http://www.abrapso.org.br/siteprincipal/index.php?option=com_content\&task=bl ogcategory\&id=67\&Itemid=95 > . Acesso em: 14 out. 2015.

LOIZOS, Peter. Vídeo, filme e fotografias como documento de pesquisa. In: BAUER, Martin W.; GASKEL, George (Org.). Pesquisa qualitativa com texto: imagem e som: um manual prático. Trad. Pedrinho A Guareschi. 11. ed. Petrópolis: Vozes, 2013. p. 137-155.

LOURO, Guacira Lopes. O cinema como pedagogia. In: LOPES, Eliane Marta Teixeira; FARIA FILHO, Luciano Mendes; VEIGA, Cynthia Greive (Org.). 500 anos de educação no Brasil. 2. ed. Belo Horizonte: Autêntica, 2000. p. 423-446. 
LOURO, Guacira Lopes. Cinema e sexualidade. Educação e Realidade, v. 33, n. 1, p. 81-98, jan./jun. 2008.

\begin{abstract}
Destemidos, bravos, solitários: a masculinidade na versão western. Bagoas, n. 10, p. 171-182, 2013. Disponível em: <http://periodicos.ufrn.br/bagoas/article/download/5382/4397>. Acesso em: 14 out. 2015.
\end{abstract}

LUDKE, Menga; ANDRÉ, Marli. Pesquisa em educação: abordagens qualitativas. Temas Básicos de Educação e Ensino. São Paulo: EPU, 1986.

MARRATI, Paola. Imagem e ceticismo: sobre o vínculo entre cinema e realidade na obra de Stanley Cavell. Educação e Realidade, n. 33, p. 49-58, jan./jun. 2008.

MARTÍN-BARBERO, Jesús. Desafios culturais da comunicação à educação. Comunicação \& Educação, São Paulo, n. 18, p. 51- 61, maio/ago. 2000.

; REY, Germán. Os exercícios do ver: Hegemonia audiovisual e ficção televisiva. Trad. Jacob Gorender. 2 ed. São Paulo: Editora Senac São Paulo, 2004.

Dos meios às medicações: comunicação, cultura e hegemonia. Trad. Ronald Polito e Sérgio Alcides. 7. ed. Rio de Janeiro: Editora UFRJ, 2013.

MATTA, João Paulo Rodrigues. Marcos histórico-estruturais da indústria cinematográfica: hegemonia norte-americana e convergência audiovisual. In: ENCONTRO DE ESTUDOS MULTIDISCIPLINARES EM CULTURA (Enecult). 4., 2008, Salvador. Anais eletrônicos... Salvador: Enecult, 2008. Disponível em: $<$ http:// http://www.cult.ufba.br/enecult2008/14363-01.pdf>. Acesso em: 19 jun. 2017.

MEDEIROS, Sérgio Augusto Leal de. Imagens educativas do cinema. Curitiba: Appris, 2016.

MERITT; FUNDAÇÃO LEMANN. Respostas dos estudantes de $5^{\circ}$ ano para todas as questões, $2015 . \quad$ Disponível em: <http://www.qedu.org.br/escola/148687-em-jose-calilahouagi/pessoas/aluno5ano>. Acesso em: 12 set. 2017.

MERLO, Andréia Todeschini. A experiência da construção da imagem na escola pública: impactos no currículo e desafios no cotidiano. In: BARBOSA, Maria Carmen Silveira; SANTOS, Maria Angélica (Org.). Escritos de alfabetização audiovisual. Porto Alegre: Libretos, 2014.

MORIN, Edgar. As estrelas: mito e sedução no cinema. Trad. Luciano Trigo. Rio de Janeiro: José Olympio, 1989. 
NOGUEIRA, Luís. Manuais de cinema II: géneros cinetográficos. LabCom Books, 2010. Disponível em: <http://www.labcom-ifp.ubi.pt/ficheiros/nogueiramanual_II_generos_cinematograficos.pdf>. Acesso em: 20 jun. 2017.

OROZCO GOMES, Guillermo. Medios, audiencias y mediaciones. Comunicar, n. 8, p. 25-30, 1997.

Las mediación em juego. Televisión, cultura y audiências. Comunicación y Sociedad, n. 10-11, p. 107-128, 1999.

Mídia, recepção e educação. Revista FAMECOS, Porto Alegre, n. 26, p. 16-23, abr. 2005.

O'SULIVAN, Tim et al. Conceitos-chave em estudos de comunicação e cultura. Trad. Margarete Griesse e Amós Nascimento. Piracicaba: Editora Unimep, 2001.

PACHECO, Raquel. Jovens, media e estereótipos: diário de campo numa escola dita problemática. Lisboa: Livros Horizonte, 2009. (Media e Jornalismo).

PAIS, José Machado. Jovens, bandas musicais e revivalismos tribais. In: ; BLASS, Leila Maria da Silva. Tribos urbanas, produção artística e identidades. Lisboa: ICS, 2004. p. 11-22.

PAIS, José Machado. A Juventude como Fase de Vida: dos ritos de passagem aos ritos de impass. Saúde Soc., São Paulo, v. 18, n. 3, p. 371-381, 2009.

De uma geração rasca a uma geração à rasca: jovens em contexto de crise. In: CARRANO, Paulo; FÁVERO, Osmar (Org.). Narrativas juvenis e espaços públicos: olhares de pesquisa em educação, mídia e ciências sociais. Niterói: Editora da UFF, 2014. p. 71-96.

PAPO de Cinema. Saga Velozes e Furiosos. Disponível em: $<$ http://www.papodecinema.com.br/especiais/saga-velozes-e-furiosos >. Acesso em: 29 maio 2017.

PROENÇA FILHO, Domício. A trajetória do negro na literatura brasileira. Estudos Avançados, v. 18, n. 50, p. 161-193, 2004. Disponível em: <http://www.scielo.br/pdf/ea/v18n50/a17v1850.pdf>. Acesso em: 9 jul. 2017.

PROGRAMA Roda Viva. Entrevista com Jesús Martín-Barbero. Exibido em 22 out. 2002. Disponível em: <https://www.youtube.com/watch?v=fiPo2yGOMf8>. Acesso em: 28 ago. 2015.

RAMOS, Ana Lúcia Azevedo. TEIXEIRA, Inês Assunção de Castro. Os professores e o cinema na companhia de Bergala. Revista Contemporânea de Educação, v. 5, n. 10, p. 7-22, jul./dez. 2010. 
REGUILLO, Rossana. Las Culturas juveniles: um campo de estúdio - breve agenda para la discusión. Revista Brasileira de Educação, n. 23, p. 103-118, 2003.

ROMERO, César. Fora de lugar. Tribuna de Minas, Juiz de Fora, 5 set. 2010.

ROSA, Gisela Ramos; PAIS, José Machado. Zona J: de uma estética de consumo a uma estética do crime. In: TEIXEIRA, Inês Assunção de Castro; LOPES, José de Sousa Miguel; DAYRELL, Juarez (Org.). A juventude vai ao cinema. Belo Horizonte: Autêntica, 2009. p. 87-104.

SACRAMENTO, Winston de Carvalho Vieira do. A experiência televisiva como mediadora da relação de crianças com o cinema. 2008. Dissertação (Mestrado em Educação) - Pontifícia Universidade Católica do Rio de Janeiro, Rio de Janeiro, 2008.

SARLO, Beatriz. Cenas da vida pós-moderna: intelectuais, arte e videocultura na Argentina. Trad. Sérgio Alcides. 5. ed. Rio de Janeiro: Editora da UFRJ, 2013.

SAVAGE, Jon. A criação da juventude: como o conceito de teenage revolucionou o século XX. Trad. Talita M. Rodrigues. Rio de Janeiro. Rocco, 2009.

SEFTON, Ana Paula; MARTINS, Jaqueline. Representações de corpo na literatura infanto-juvenil. In: CARVALHO, Marie Jane Soares; ROCHA, Christianne Maria Famer (Org.). Produzindo gênero. Porto Alegre: Sulina, 2004. p. 279-293.

SILVA, Fernando Rodrigo dos Santos. A arte de ver uma comunidade e espectadores: a infância em cena. 2007. Dissertação (Mestrado em Educação) - Pontifícia Universidade Católica do Rio de Janeiro, Rio de Janeiro, 2007.

SODRÉ, Muniz. Teoria da literatura de massa. Rio de Janeiro: Tempo Brasileiro, 1978.

SOUSA, Mauro Wilton. Recepção e comunicação: a busca do sujeito. In: SOUSA, Mauro Wilton (Org.). Sujeito, o lado oculto do receptor. São Paulo: Brasiliense, 1995. p. 13-38.

SPÓSITO, Marília Pontes. Prefácio. In: TEIXEIRA, Inês Assunção de Castro; LOPES, José de Sousa Miguel; DAYRELL, Juarez (Org.). A juventude vai ao cinema. Belo Horizonte: Autêntica, 2009. p. 9- 13.

TROVÃO, Flávio Vilas-Bôas. O exército inútil de Robert Altman: cinema e política. 2010. Tese (Doutorado em História Social) - Universidade de São Paulo, São Paulo, 2010.

VICTORIANO, Felipe; DARRIGRANDI, Claudia. Representación. In: SZURMUK, Mónica; IRWIN, Robert McKee (Coord.). Diccionario de Estudios Culturales Latino-Americanos. México: Siglo XXI, 2009. p. 250-255. 
Apêndices

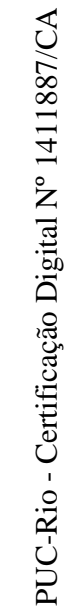




\section{APÊNDICE A}

\section{NOTAS DE CAMPO DE PARTE DO DÉCIMO ENCONTRO}

No décimo terceiro encontro, conforme combinado, os jovens apresentaram os filmes que gostariam de ver naquele semestre. Percebi que muitos deles se prepararam para o momento, levando a sinopse e outras informações sobre os filmes sugeridos. Na Turma 1, foram indicados 5 filmes: Jack - O Caçador de Gigantes (direção de Bryan Singer, EUA, 2013), João e Maria: caçadores de bruxas (direção de Tommy Wirkola, EUA, 2013), Deus não está morto (direção de Harold Cronk, EUA, 2014), Guardiões da Galáxia (direção de James Gunn, EUA, 2014), As crônicas de Nárnia: o Leão, a Feiticeira e o Guarda-Roupa (direção de Andrew Adamson, EUA, 2005). Dos 5 filmes, os dois mais votados foram João e Maria: caçadores de bruxas e As crônicas de Nárnia: o Leão, a Feiticeira e o Guarda-Roupa, como o segundo teve um voto a menos que o primeiro, decidimos que os dois seriam exibidos. Na Turma 2, oito filmes foram indicados: X-Men - O Confronto final (direção de Bret Ratner, EUA, 2006), Invocação do Mal II (direção de James Wan, EUA, 2016), Harry Potter e as Relíquias da Morte - Parte 2 (direção de David Yates, EUA, 2011), O Orfanato (direção de Sérgio Sanches, Espanha/México, 2007), Jurassic World: o mundo dos dinossauros (direção de Colin Trevorrow, EUA, 2015), Alice Através do Espelho (direção de James Bobin, EUA, 2016), Star Wars: 0 Despertar da Força (direção de J.J. Abrams, EUA, 2015), A órfã (direção de Jaume Colete-Serra, EUA, 2009). O filme mais votado foi Invocação do Mal II, mas ele não é recomendado para menores de 16 anos, por ser um filme de terror, o que contraindicava a exibição. Optei por exibir o segundo filme mais votado, Jurassic World: o mundo dos dinossauros. Nos encontros posteriores, voltamos à discussão sobre o filme escolhido, pois muitos insistiam em ver Invocação do Mal II, depois consegui convencê-los de que não era possível exibi-lo. Dessa forma, nos encontros seguintes foram exibidos: As crônicas de Nárnia: o Leão, a Feiticeira e o Guarda-Roupa, João e Maria: caçadores de bruxas e Jurassic World: o mundo dos dinossauros. Interessante perceber que um dos filmes sugeridos, Guardiões da Galáxia, era um dos que estavam na lista de mais vistos nos cinemas brasileiros em 2014. Outra questão importante é que apenas um dos filmes sugeridos não é estadunidense, O Orfanato é uma produção de Espanha e México, porém nenhum deles ficou entre os filmes mais votados. 


\section{APÊNDICE B \\ PONTIFÍCIA UNIVERSIDADE CATÓLICA DO RIO DE JANEIRO \\ Programa de Pós-Graduação em Educação}

Este questionário é parte da pesquisa de campo de doutorado, desenvolvida por Carla Silva Machado, sob a orientação da professora Rosália Maria Duarte. Titulo do projeto de pesquisa: "Espelho, Espelho meu?": Narrativas Audiovisuais Acerca das Juventudes e Relações Juvenis. A primeira parte do questionário apresenta questões relativas às experiências com o audiovisual e a segunda parte, perguntas que tratam das práticas cotidianas dos respondentes com o audiovisual.

\section{Questionário}

Nome:

Idade: Série/Ano:

\section{Experiências com o Audiovisual}

1) Você via filmes quando era criança? ( ) sim ( ) não

2) Lembra que idade tinha quando começou a ver filmes?

( ) menos de 6 anos;

( ) entre 6 e 9 anos;

( ) mais de 9 anos.

3) Onde você via filmes quando era criança?

( ) em casa (TV, DVD);

( ) casa de amigos ou parentes;

( ) no cinema.

4) Gosta de assistir a filmes?

( ) $\operatorname{sim}$ ( ) não

5) Você ia ao cinema quando era criança?

( ) sim, com frequência;

() sim, às vezes;

() muito raramente;

( ) nunca

6) Se sim: (Caso tenha marcado nunca na questão 5 , não responda esta pergunta): Marque as opções que indicam com quem você costumava ir ao cinema quando criança (pode marcar mais de uma opção):

( ) com meus pais ou responsáveis;

() com colegas;

() numa atividade da escola;

() sozinho(a).

( ) Outras. Quais?

7) Costuma ir ao cinema?

( ) $\operatorname{sim}$ ( ) não

8) Se você marcou sim, indique a frequência com que faz isso?

( ) Toda semana;

( ) Todo mês;

( ) Duas vezes por ano;

() Uma vez por ano;

( ) Fui poucas vezes ao cinema (menos de 10); 
9) Onde você assiste a filmes com mais frequência?

( ) Cinema;

( ) TV aberta;

( ) TV paga;

( ) DVDs/Blu-Ray;

( ) Internet (ex: YouTube/ filmes on line grátis);

( ) Filmes por demanda (ex: Netflix);

( ) Celular;

() Escola;

( ) Outros; Quais?

10) Quantos filmes, em média, você vê por semana?

( ) Nenhum;

( ) Um;

( ) Dois;

( ) Três;

() Quatro;

( ) Cinco ou mais.

11) Como escolhe o filme que vai assistir? (marque apenas 2 opções, as mais relevantes)

( ) pela recomendação de colegas, parentes e amigos;

( ) pela propaganda;

( ) pelo gênero do filme;

( ) pelo diretor do filme;

() pelo ator/atriz do filme.

12) Além de filmes, você costuma assistir a séries?

( ) $\operatorname{sim}($ ) não

Se sim, escreva abaixo os nomes das séries de que mais gosta? (no máximo 3)

(se você não assiste a séries, deixará esta questão em branco)

13) Você costuma conversar sobre os filmes que assistiu com seus colegas ou pessoas próximas? ( ) sim ( ) não

14) Você assiste a filmes na escola? ( ) sim ( ) não (se sim, responda à próxima pergunta, se não, pule para a questão 15)

a) Os filmes que assistiu na escola estavam relacionados ao conteúdo de alguma matéria?

( ) $\operatorname{sim}($ ) não

Qual(is)?

15) Qual foi o último filme que você viu?

16) Tem algum filme que você gostaria de ver, mas ainda não teve oportunidade? Qual (is)? 


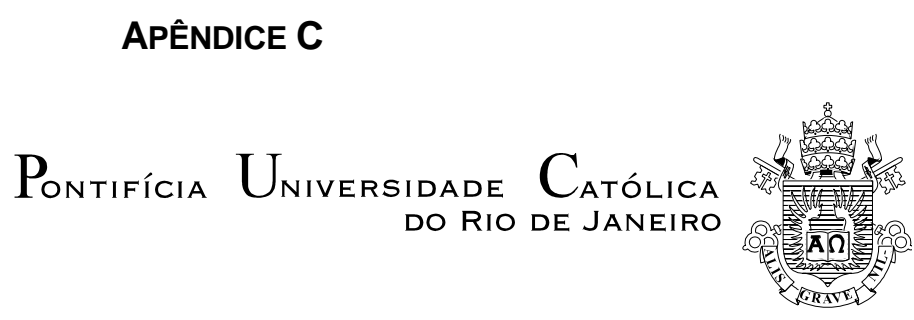

TERMO DE ASSENTIMENTO LIVRE E ESCLARECIDO

Prezado/a estudante da Escola Municipal José Calil Ahouagi

Você está sendo convidado(a) a participar, como voluntário(a), da pesquisa intitulada "Espelho, Espelho meu?": Narrativas Audiovisuais

Acerca das Juventudes e Relações Juvenis, desenvolvida pela doutoranda Carla Silva Machado e orientada pela professora Rosália Maria Duarte, do Departamento de Educação da PUC-Rio. Este estudo tem o objetivo de compreender as relações de jovens com filmes e analisar possíveis influências dos filmes no modo como os jovens entendem a juventude. Os participantes terão a oportunidade de refletir sobre suas relações com o cinema e sobre como essa relação contribui para a sua identidade como jovem.

Sua participação não é obrigatória. A qualquer momento, você poderá desistir de participar e retirar seu assentimento. Sua recusa, desistência ou retirada de assentimento não acarretará prejuízo. A participação não é remunerada nem implicará gastos para os participantes. A pesquisa não acarretará nenhum tipo de risco, visto que serão atividades muito parecidas com as já desenvolvidas no Projeto de Contadores de Histórias, a única diferença é que serão registradas em áudio e/ou vídeo para posterior análise.

Sua participação consistirá na realização de atividades semanais, no Projeto Contadores de Histórias, no qual serão oferecidas oficinas de visualização de filmes, com posteriores rodas de conversas acerca dos filmes assistidos. Solicitamos sua autorização para registrar em áudio e/ou vídeo estas atividades e a assinatura do Termo de Cessão de uso de Imagens, Anexo a este Termo de Assentimento. Caso você concorde em participar, solicitaremos que você preencha um questionário que trata da sua relação com o audiovisual.

Os dados obtidos por meio desta pesquisa serão confidenciais e não serão divulgados em nível individual, visando assegurar o sigilo de sua participação e a de sua escola. O pesquisador responsável se compromete a tornar públicos nos meios acadêmicos e científicos estes resultados, de forma consolidada, sem qualquer identificação dos indivíduos participantes. 
Caso você concorde em participar desta pesquisa, assine ao final deste documento, que possui duas vias, sendo uma delas sua, e a outra, do pesquisador responsável / coordenador da pesquisa.

Seguem os telefones e o endereço institucional do pesquisador responsável pelo projeto, da orientadora e da Comissão de Ética em Pesquisa CEP, onde você poderá tirar suas dúvidas sobre o projeto e sobre sua participação nele, agora ou a qualquer momento.

Contatos do pesquisador responsável: Carla Silva Machado. E-mail: carlasingular@yahoo.com.br; Celular (32)99953-9849 (Doutoranda responsável pelo desenvolvimento da pesquisa). Rosália Duarte (Orientadora), Professora Associada da PUC-Rio. E-mail: rosalia@puc-rio.br; Telefone (21) 35272825 (Orientadora).

Endereço postal: Faculdades Católicas, Departamento de Educação. Marquês de São Vicente, 225, Gávea, CEP 22451-900. Comissão de Ética em Pesquisa da PUC-Rio 213527.

\section{Declaro que entendi os objetivos, riscos e benefícios de minha participação} na pesquisa, e que concordo em participar.

Juiz de Fora, de de

Assinatura do(a) participante:

Assinatura do(a) pesquisador(a): 


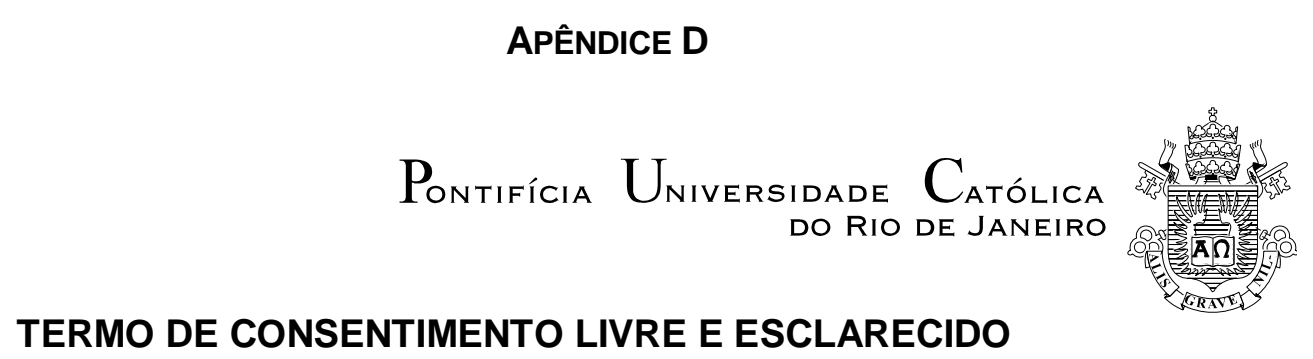

Prezado/a pai/mãe/responsável,

Seu/sua filho/filha está sendo convidado(a) a participar, como voluntário(a), da pesquisa intitulada "Espelho, Espelho meu?": Narrativas Audiovisuais Acerca das Juventudes e Relações Juvenis, desenvolvida pela doutoranda Carla Silva Machado e orientada pela professora Rosália Maria Duarte do Departamento de Educação da PUC-Rio. Este estudo tem o objetivo de analisar o entendimento de como as narrativas audiovisuais contribuem na configuração de representações de juventude e a percepção dos jovens sobre essa representação. Os participantes terão a oportunidade de refletir sobre suas relações com o cinema, e como essa relação contribui para a sua representação identitária das juventudes.

A pesquisa será realizada na escola onde seu/sua filho/filha estuda, e fará parte das atividades do Projeto Contadores de Histórias. A participação de seu/sua filho/filha não é obrigatória. A qualquer momento ele/ela poderá desistir de participar e você poderá retirar seu consentimento. Sua recusa, desistência ou retirada de consentimento não acarretará prejuízo. A participação não é remunerada nem implicará em gastos para os participantes.

A participação do seu/sua filho/filha nesta pesquisa consistirá no desenvolvimento de atividades semanais do Projeto Contadores de Histórias, em que haverá a realização de oficinas de visualização de filmes com posteriores rodas de conversas acerca dos filmes assistidos. Solicitamos, ainda, sua autorização, para registrar em vídeo, estas atividades desenvolvidas no projeto. Solicitamos também que seu/sua filho/filha preencha um questionário que trata da sua relação com o audiovisual.

Nossas observações não comprometerão as atividades que seu/sua filho/filha costuma fazer. A visita e todas as atividades serão agendadas previamente com a professora responsável pelo projeto.

Os dados obtidos por meio desta pesquisa não serão divulgados em nível individual, visando assegurar o sigilo de sua participação. As pesquisadoras responsáveis se comprometem a tornar públicos, nos meios acadêmicos e 
científicos, estes resultados de forma consolidada, sem qualquer identificação de indivíduos participantes.

Caso você concorde com a participação de seu filho/filha ou criança sob sua responsabilidade nesta pesquisa, assine ao final deste documento, que possui duas vias, sendo uma delas sua, e a outra, das pesquisadoras responsáveis/ coordenadoras da pesquisa. Ressaltamos que as oficinas não têm nenhum tipo de risco para o seu filho/a, visto que serão atividades muito parecidas com as já desenvolvidas no Projeto de Contadores de Histórias, a única diferença é que serão registradas em áudio e/ou vídeo para posterior análise.

Seguem os telefones e o endereço institucional das pesquisadoras responsáveis e da Comissão de Ética em Pesquisa - CEP, onde você poderá tirar suas dúvidas sobre o projeto e sua participação nele, agora ou a qualquer momento.

Contatos do pesquisador responsável: Carla Silva Machado. E-mail: carlasingular@yahoo.com.br; Celular (32)99953-9849 (Doutoranda responsável pelo desenvolvimento da pesquisa). Rosália Duarte (Orientadora), Professora Associada da PUC-Rio. E-mail: rosalia@puc-rio.br; Telefone (21) 35272825 (Orientadora).

Endereço postal: Faculdades Católicas, Departamento de Educação. Marquês de São Vicente, 225, Gávea, CEP 22451-900. Comissão de Ética em Pesquisa da PUC-Rio 213527.

Declaro que entendi os objetivos, riscos e benefícios da participação de meu filho/filha na pesquisa, e que concordo que ela participe. Autorizo também que sejam feitos registros em áudio e/ou vídeo das atividades desenvolvidas durante o projeto.

Juiz de Fora, de de

Assinatura do(a) responsável pelo participante:

Assinatura do(a) pesquisador(a): 


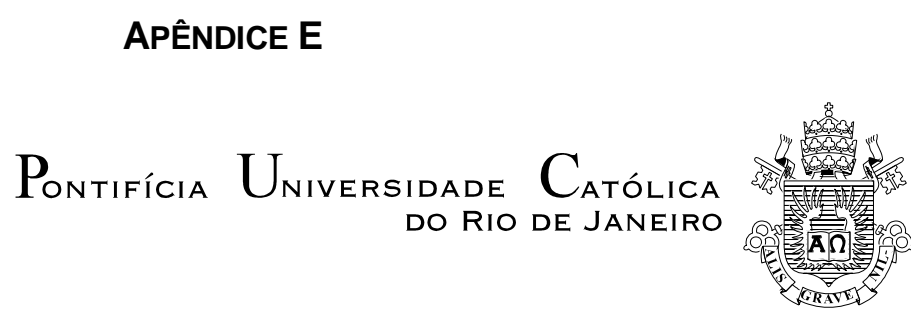

TERMO DE CONSENTIMENTO LIVRE E ESCLARECIDO

Prezada professora,

Você está sendo convidada a participar, como voluntária, da pesquisa intitulada “Espelho, Espelho meu?": Narrativas Audiovisuais Acerca das Juventudes e Relações Juvenis, desenvolvida pela doutoranda Carla Silva Machado e orientada pela professora Rosália Maria Duarte do Departamento de Educação da PUC-Rio. Este estudo tem o objetivo de analisar o entendimento de como as narrativas audiovisuais contribuem na configuração de representações de juventude e a percepção dos jovens sobre essa representação. Os participantes terão a oportunidade de refletir sobre suas relações com o cinema, e como essa relação contribui para a sua representação identitária das juventudes.

Sua participação não é obrigatória. A qualquer momento, você poderá desistir de participar e retirar seu consentimento. Sua recusa, desistência ou retirada de consentimento não acarretará prejuízo. A participação não é remunerada nem implicará em gastos para os participantes.

Sua participação nesta pesquisa consistirá em compartilhar suas aulas semanais com a turma do Projeto Contadores de Histórias para a realização de oficinas de visualização de filmes com posteriores rodas de conversas acerca dos filmes assistidos. Solicitamos, ainda, sua autorização, para registrar em vídeo e/ou áudio, estas atividades desenvolvidas no projeto. Nossas intervenções serão semanais e farão parte das atividades do projeto desenvolvido por você com as turmas, portanto, não comprometerão o curso normal das atividades e serão agendadas previamente, vindo a ocorrer em dias e horários que você e os demais integrantes do projeto julgarem mais convenientes.

Os dados obtidos por meio desta pesquisa serão confidenciais e não serão divulgados em nível individual, visando assegurar o sigilo de sua participação e a de sua escola. O pesquisador responsável se comprometeu a tornar públicos 
nos meios acadêmicos e científicos os resultados obtidos de forma consolidada sem qualquer identificação de indivíduos participantes.

Caso você concorde em participar desta pesquisa, assine ao final deste documento, que possui duas vias, sendo uma delas sua, e a outra, do pesquisador responsável.

Seguem os telefones e o endereço institucional do pesquisador responsável e da Comissão de Ética em Pesquisa - CEP, onde você poderá tirar suas dúvidas sobre o projeto e sua participação nele, agora ou a qualquer momento.

Contatos do pesquisador responsável: Carla Silva Machado. E-mail: carlasingular@yahoo.com.br; Celular (32)99953-9849 (Doutoranda responsável pelo desenvolvimento da pesquisa). Rosália Duarte (Orientadora), Professora Associada da PUC-Rio. E-mail: rosalia@puc-rio.br; Telefone (21) 35272825 (Orientadora).

Endereço postal: Faculdades Católicas, Departamento de Educação. Marquês de São Vicente, 225, Gávea, CEP 22451-900. Comissão de Ética em Pesquisa da PUC-Rio 213527.

\section{Declaro que entendi os objetivos, riscos e benefícios de minha participação na pesquisa, e que concordo em participar.}

Juiz de Fora, de de Assinatura do(a) participante: Assinatura do(a) pesquisador(a): 


\section{APÊNDICE F}

Escola Municipal José Calil Ahouagi - Projeto Contadores de História Nome:

Após assistir ao filme: A culpa é das estrelas e conhecer Hazel e Agustus, as personagens principais, se você fosse o autor do roteiro do filme, como você caracterizaria as personagens principais (seus gostos/ suas características físicas /em que cidade onde morariam?/ Onde se conheceriam?/ idade/ para onde iriam viajar?/ O que seria o empecilho para eles viajarem?/ Quem eles gostariam de conhecer?/ Como o ídolo deles os trataria?/Como seria o desfecho do filme?):

\begin{tabular}{|c|c|c|}
\hline Os Personagens & $\begin{array}{l}\text { Hazel Grace (Atriz: Shailene } \\
\text { Woodley). } \\
\text { Ela tem dezesseis anos, } \\
\text { olhos verdes, pele clara. } \\
\text { Tem câncer de tireoide com } \\
\text { metástase nos pulmões. É fã } \\
\text { do escritor Peter Van Houten } \\
\text { e quer conhecê-lo, ele vive } \\
\text { na Holanda. }\end{array}$ & $\begin{array}{l}\text { Augustus (Ator: Ansel } \\
\text { Elgort). } \\
\text { Ele tem dezessete anos, alto, } \\
\text { magro. É bonito e sabe muito } \\
\text { bem disso. Gosta de música, } \\
\text { livros e games. Tem câncer } \\
\text { nos ossos. }\end{array}$ \\
\hline $\begin{array}{l}\text { Três características } \\
\text { físicas: }\end{array}$ & & \\
\hline Idade: & & \\
\hline 2 gostos: & & \\
\hline $\begin{array}{l}\text { Em que cidade eles } \\
\text { moram? }\end{array}$ & & \\
\hline $\begin{array}{l}\text { Onde eles se } \\
\text { conheceriam? }\end{array}$ & & \\
\hline Quem é o ídolo deles? & & \\
\hline $\begin{array}{l}\text { Para onde eles queriam } \\
\text { viajar? }\end{array}$ & & \\
\hline $\begin{array}{l}\text { O que poderia atrapalhar } \\
\text { a viagem deles? }\end{array}$ & & \\
\hline $\begin{array}{l}\text { Como o ídolo deles os } \\
\text { trataria? }\end{array}$ & & \\
\hline $\begin{array}{l}\text { Como seria o desfecho } \\
\text { do filme? }\end{array}$ & & \\
\hline $\begin{array}{lr}\text { Você gostaria } & \text { de } \\
\text { acrescentar mais } & \text { algum } \\
\text { detalhe } & \text { aos } \\
\text { personagens? } & \end{array}$ & & \\
\hline
\end{tabular}

Obrigada pela sua participação. Grande abraço. Carla Machado (:) 
169

APÊNDICE G

Projeto contadores de Histórias - 25/08/2016

Sobre o filme Jogos vorazes- A Esperança - Parte 1

Nome:

Crie um figuro para a personagem da Katniss (Jennifer Lawrence) que você considere mais adequado à personagem. Depois escreva um comentário justificando a sua escolha pelo figurino que você criou.

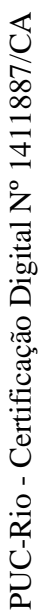
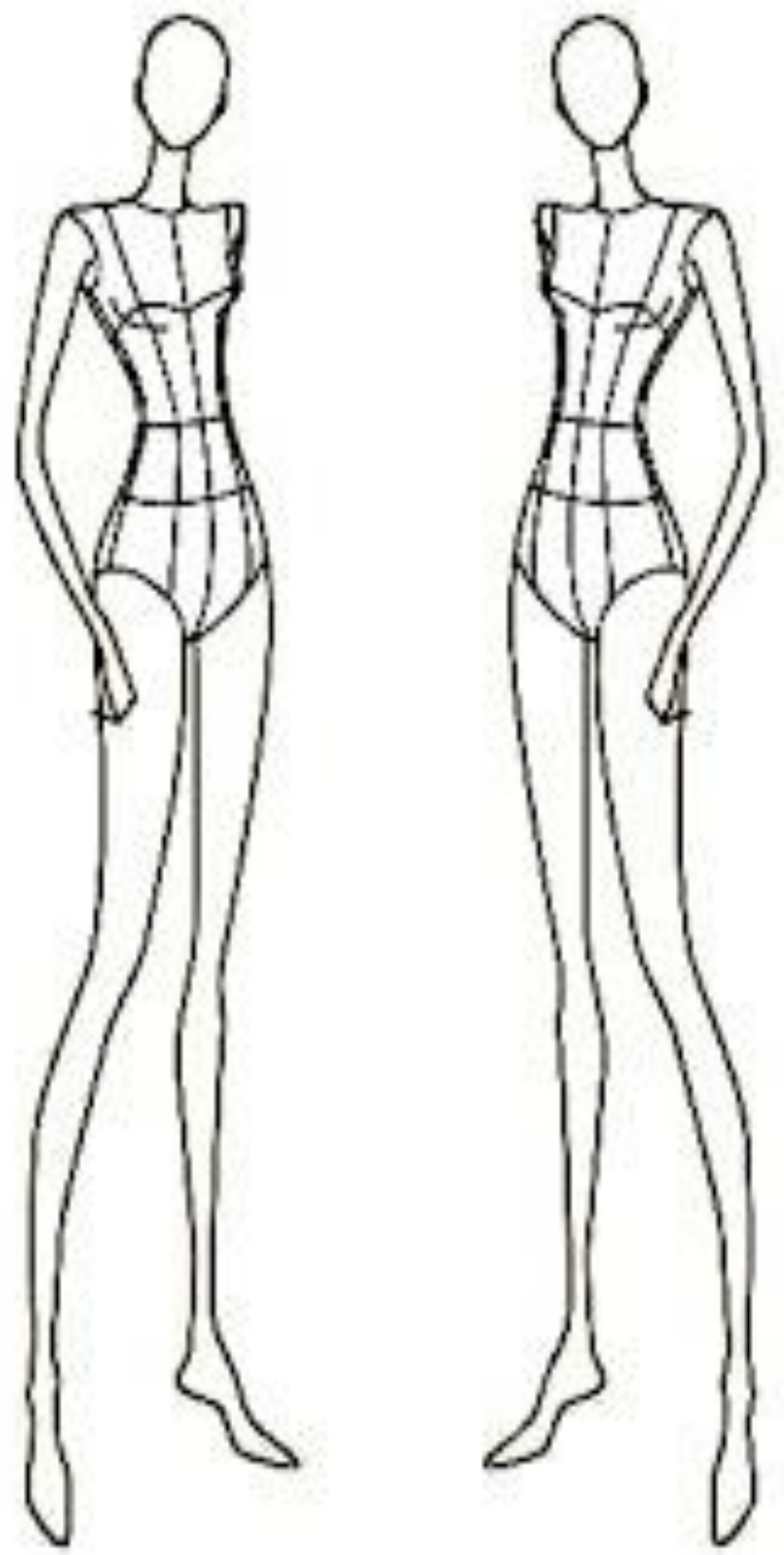


\section{APÊNDICE H \\ Projeto Contadores de Histórias - 29/09/2016}

Nome:

A história João e Maria: caçadores de bruxas é uma espécie de continuação da história infantil João e Maria, dois meninos abandonados pelos pais que vão viver numa casa cheia de doces e caem nas mãos de uma bruxa que os engorda para poder comê-los.

No filme, os irmãos viram caçadores de bruxas após conseguirem se libertar da bruxa.

Caso você criasse um roteiro para este filme, como seria seu filme?

1) Onde se passaria a história? Em que época?

2) Qual seria a trilha sonora do filme?

3) Que profissão João e Maria teriam?

4) Que atores você chamaria para interpretar os irmãos?

5) Que características principais você daria para João?

6) Que características principais você daria para Maria?

7) Faça uma pequena sinopse (resumo) do filme que você criaria. 
APÊNDICE I

Contadores de histórias - 08/12/2016

Nome:

Idade: Ano:

Sobre o filme: As melhores coisas do Mundo, comente:

a) Você gostou? Por quê?

b) Destaque uma cena que você tenha gostado mais? Justifique a escolha.

c) Em relação aos filmes norte-americanos, o que você percebe de diferença? Isso é bom ou ruim? Por quê?

d) Você recomendaria este filme? Por quê? 


\section{APÊNDICE J \\ ARGUMENTO DO FILME DETALHADO ENTREGUE PELOS ALUNOS}

Título: 3 FORCES

Início: o filme começa na escola com uma briga geral entre dois dos três protagonistas (João, Ana e Carla) ${ }^{46}$. Ana mata João e Carla volta no tempo para consertar o passado.

Estamos em uma escola. Ocorre bullying no fim de uma aula. Há vários alunos xingando os outros: você é nerd. Você é gordo. Você é baixinho! Sua magrela! Seu cabelo é feio! As vítimas do bullying ficam irritadas e começam a brigar com os agressores.

Meio: após a briga, as vítimas saem machucadas e vão para o hospital. Após tomar o mesmo remédio, eles começam a ter reações estranhas e em uma briga de família com seus pais, João quebra uma porta e seus pais ficam assustados. João conversa com Carla e Ana. Ana diz que aconteceu a mesma coisa com ela.

Fim: Ana fica revoltada e começa a agredir quem praticou bullying contra ela e seus amigos. João revoltado, tenta a impedir der ser violenta. Carla ainda não percebe que tem superpoderes.

Carla tenta impedir a briga entre os dois que estão deslumbrados com os novos poderes, mas já que ela não percebeu que tem poderes, ela não consegue controlar seus amigos.

Carla volta no tempo e sai da aula com seus amigos antes de começar as agressões a eles. Assim ela consegue mudar o passado e fazer com que os amigos fiquem vivos.

\footnotetext{
${ }^{46}$ Os nomes dos protagonistas foram alterados pelos jovens, tendo ficado: Eduardo, Gabriela e Carla.
} 